Nevada

Environmental

Restoration

Project

\title{
Closure Report for Corrective Action Unit 130: Storage Tanks Nevada Test Site, Nevada
}

Controlled Copy No.:

Revision No.: 0

March 2009

Approved for public release; further dissemination unlimited.

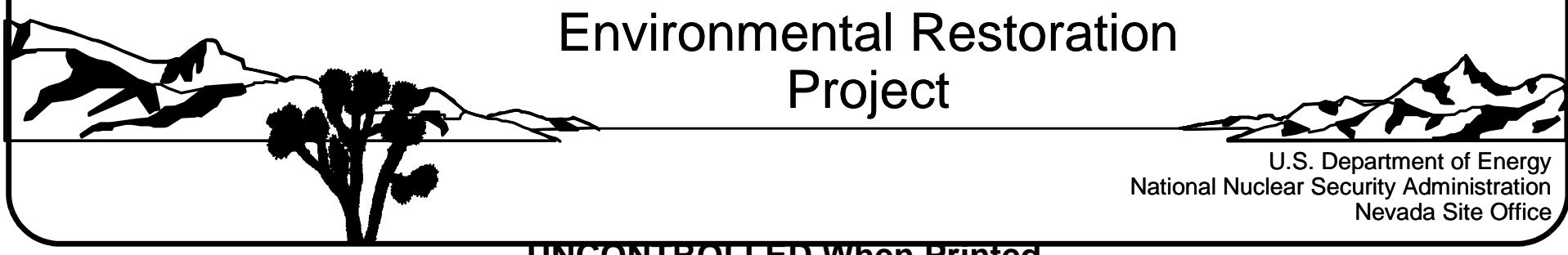


Available for sale to the public from:

U.S. Department of Commerce

National Technical Information Service

5285 Port Royal Road

Springfield, VA 22161

Phone: 800.553 .6847

Fax: 703.605.6900

Email: orders@ntis.gov

Online ordering: http://www.ntis.gov/ordering.htm

Available electronically at http://www.osti.gov/bridge

Available for a processing fee to U.S. Department of Energy and its contractors, in paper, from:

U.S. Department of Energy

Office of Scientific and Technical Information

P.O. Box 62

Oak Ridge, TN 37831-0062

Phone: 865.576.8401

Fax: 865.576.5728

Email: reports@adonis.osti.gov

Reference herein to any specific commercial product, process, or service by trade name, trademark, manufacturer, or otherwise, does not necessarily constitute or imply its endorsement, recommendation, or favoring by the United States Government or any agency thereof or its contractors or subcontractors. 


\title{
CLOSURE REPORT FOR CORRECTIVE ACTION UNIT 130: STORAGE TANKS NEVADA TEST SITE, NEVADA
}

\author{
U.S. Department of Energy \\ National Nuclear Security Administration \\ Nevada Site Office \\ Las Vegas, Nevada
}

Controlled Copy No.:

Revision No.: 0

March 2009

Approved for public release; further dissemination unlimited.

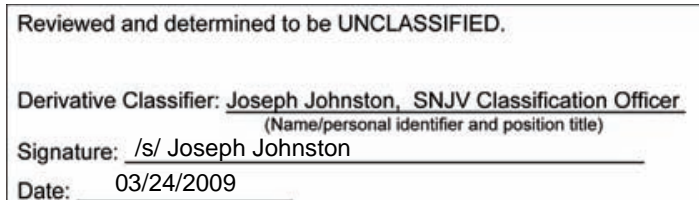




\section{CLOSURE REPORT FOR \\ CORRECTIVE ACTION UNIT 130: \\ STORAGE TANKS \\ NEVADA TEST SITE, NEVADA}

Approved by:_ Is/ Kevin J. Cabble

Date: 03/23/2009

Kevin J. Cabble

Federal Sub-Project Director

Industrial Sites Sub-Project

Approved by: _ /s/ Robert F. Boehlecke

Date: 03/23/2009

Robert F. Boehlecke

Federal Project Director

Environmental Restoration Project 


\section{Table of Contents}

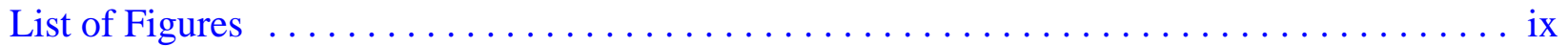

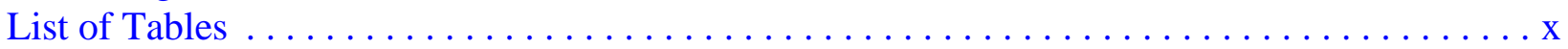

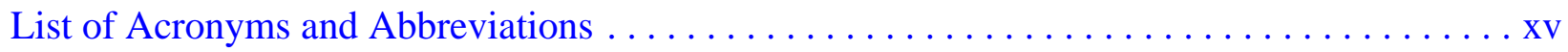

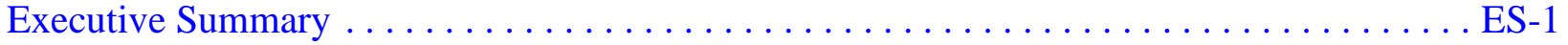

$1.0 \quad$ Introduction. . . . . . . . . . . . . . . . . . . . . . . . . . . . . 1

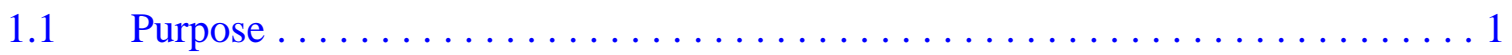

$1.2 \quad$ Scope..........................................

$1.3 \quad$ Closure Report Contents.............................. 4

1.3.1 Applicable Programmatic Plans and Documents ............. 5

1.3.2 Data Quality Objectives ........................ 5

1.3.3 Data Quality Assessment Summary $\ldots \ldots \ldots \ldots \ldots \ldots \ldots \ldots \ldots$

$2.0 \quad$ Closure Activities . . . . . . . . . . . . . . . . . . . . . . . . . . . . . 8

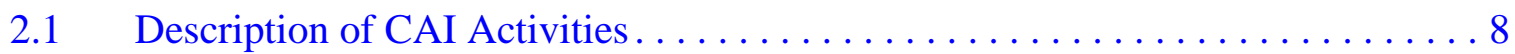

2.1.1 CAS 01-02-01 Closure Activities....................... 9

2.1.2 CAS 07-02-01 Closure Activities...................... 10

2.1.3 CAS 10-02-01 Closure Activities..................... 11

2.1.4 CAS 20-02-03 Closure Activities.................... 12

2.1.5 CAS 20-99-05 Closure Activities...................... 13

2.1.6 CAS 22-02-02 Closure Activities...................... 14

2.1.7 CAS 23-02-07 Closure Activities..................... 15

2.2 Deviations from SAFER Plan as Approved ................... 16

2.3 Corrective Action Schedule as Completed ......................... 16

2.4 Site Plans/Survey Plat. . . . . . . . . . . . . . . . . . . . . . . . . . . . 16

$3.0 \quad$ Waste Disposition...................................... 18

$3.1 \quad$ Waste Streams. . . . . . . . . . . . . . . . . . . . . . . . . . . 18

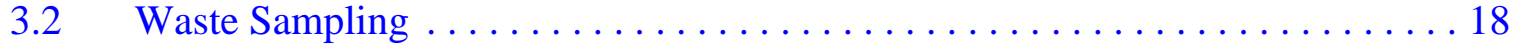

$3.3 \quad$ Waste Disposal . . . . . . . . . . . . . . . . . . . . . . . . . . . . . 19

$4.0 \quad$ Closure Verification Results.............................. 20

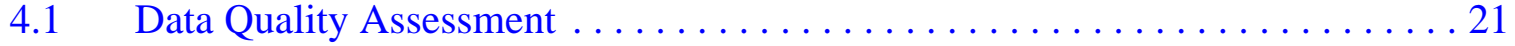

4.1.1 Review DQOs and Sampling Design ................. 22

4.1.1.1 Decision I ........................... 22

4.1.1.1.1 DQO Provisions To Limit False

Negative Decision Error .............. 22

4.1.1.1.2 DQO Provisions To Limit False

Positive Decision Error ............. 28

4.1.1.2 Decision II .......................... 28

4.1.1.3 Sampling Design ....................... 29 


\section{Table of Contents (Continued)}

4.1.2 Conduct a Preliminary Data Review .................... 29

4.1.3 Select the Test and Identify Key Assumptions................. 29

4.1.4 Verify the Assumptions ........................... 31

4.1.4.1 Other DQO Commitments $\ldots \ldots \ldots \ldots \ldots \ldots \ldots \ldots \ldots \ldots$

4.1.5 Draw Conclusions from the Data ................... 31

4.1.5.1 Decision Rules for Decision I . . . . . . . . . . . . . . 31

4.1.5.2 Decision Rules for Decision II . . . . . . . . . . . . 32

$4.2 \quad$ Use Restrictions . . . . . . . . . . . . . . . . . . . . . . . . . . . 32

$5.0 \quad$ Conclusions and Recommendations .......................... 33

6.0 References......................................... 34

\section{Appendix A - Data Quality Objectives as Developed in the SAFER Plan}

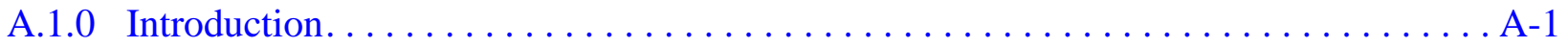

A.2.0 Step 1 - State the Problem. . . . . . . . . . . . . . . . . . . . . . A

A.2.1 Planning Team Members $\ldots \ldots \ldots \ldots \ldots \ldots \ldots \ldots \ldots \ldots \ldots \ldots \ldots . \ldots \ldots$

A.2.2 Conceptual Site Model .............................. A-3

A.2.2.1 Contaminant Release .......................... A-4

A.2.2.2 Potential Contaminants........................ A-9

A.2.2.3 Contaminant Characteristics..................... A-9

A.2.2.4 Site Characteristics ......................... A-11

A.2.2.5 Migration Pathways and Transport Mechanisms ............. A-12

A.2.2.6 Exposure Scenarios.......................... A-12

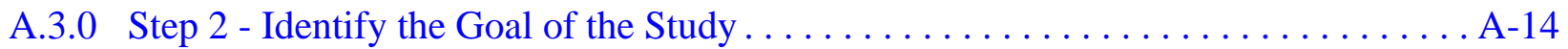

A.3.1 Decision Statements . . . . . . . . . . . . . . . . . . . . . . . A -14

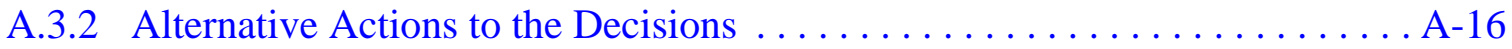

A.3.2.1 Alternative Actions to Decision I . . . . . . . . . . . . . A-16

A.3.2.2 Alternative Actions to Decision II .................. A-17

A.4.0 Step 3 - Identify Information Inputs . . . . . . . . . . . . . . . . . . . A-18

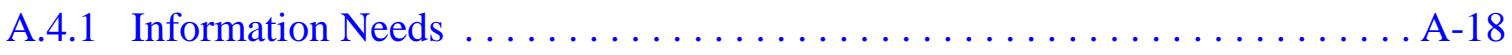

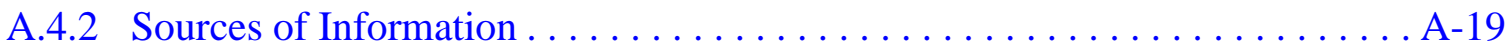

A.4.2.1 Sample Locations ......................... A-19

A.4.2.1.1 Judgmental Approach for Sampling Location Selection ..................... A-19

A.4.2.2 Analytical Methods........................ A-21

A.5.0 Step 4 - Define the Boundaries of the Study $\ldots \ldots \ldots \ldots \ldots \ldots \ldots \ldots \ldots$ A-22 


\section{Table of Contents (Continued)}

A.5.1 Target Populations of Interest. . . . . . . . . . . . . . . . A

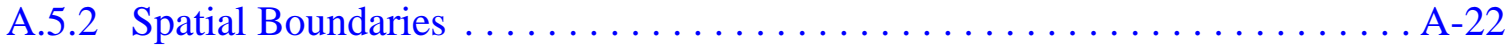

A.5.3 Practical Constraints . . . . . . . . . . . . . . . . . . A-23

A.5.4 Define the Sampling Units . . . . . . . . . . . . . . . .

A.6.0 Step 5 - Develop the Analytic Approach . . . . . . . . . . . . . . . . . . . A-25

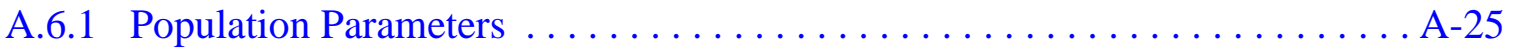

A.6.2 Action Levels . . . . . . . . . . . . . . . . . . . . . A-25

A.6.2.1 Chemical PALs............................ A-26

A.6.2.2 Total Petroleum Hydrocarbon PALs . . . . . . . . . . . . . . . . . A-27

A.6.2.3 Radionuclide PALs. . . . . . . . . . . . . . . . . . . . A-27

A.6.3 Decision Rules . . . . . . . . . . . . . . . . . A-27

A.7.0 Step 6 - Specify Performance or Acceptance Criteria . . . . . . . . . . . . . . . . . A-29

A.7.1 Decision Hypotheses. . . . . . . . . . . . . . . . . . . . . . . . A-29

A.7.2 False Negative Decision Error . . . . . . . . . . . . . . . A-29

A.7.3 False Positive Decision Error . . . . . . . . . . . . . . . A-31

A.8.0 Step 7 - Develop the Plan for Obtaining Data $\ldots \ldots \ldots \ldots \ldots \ldots \ldots \ldots \ldots \ldots$ A-33

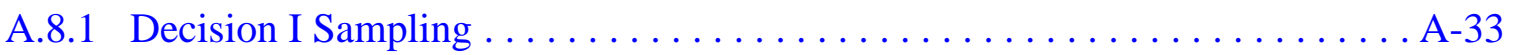

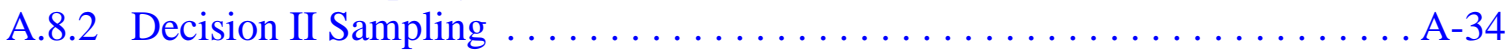

A.8.3 Corrective Action Site 01-02-01, Underground Storage Tank . . . . . . . . . . . A-34

A.8.4 Corrective Action Site 07-02-01, Underground Storage Tanks . . . . . . . . . . A-36

A.8.5 Corrective Action Site 10-02-01, Underground Storage Tank . . . . . . . . . . A-38

A.8.6 Corrective Action Site 20-02-03, Underground Storage Tank . . . . . . . . . . . A A-40

A.8.7 Corrective Action Site 20-99-05, Tar Residue . . . . . . . . . . . . . . . . . . . A-42

A.8.8 Corrective Action Site 22-02-02, Buried UST Piping . . . . . . . . . . . . . A A-42

A.8.9 Corrective Action Site 23-02-07, Underground Storage Tank . . . . . . . . . A-44

A.9.0 References.................................... A-48

\section{Appendix B - Closure Certification}

B.1.0 Closure Certification. . . . . . . . . . . . . . . . . . .

\section{Appendix C - As-Built Documentation}

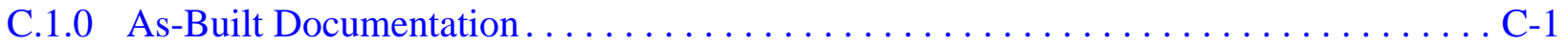




\section{Table of Contents (Continued)}

\section{Appendix D - Confirmation Sampling Test Results}

D.1.0 Introduction. . . . . . . . . . . . .

D.1.1 Project Objectives....................................

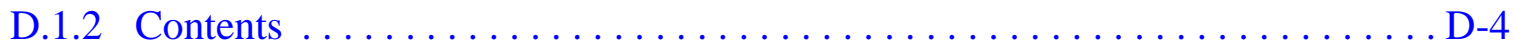

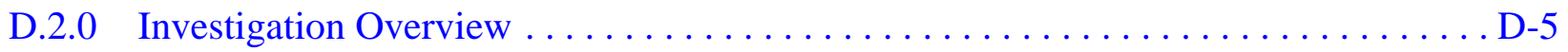

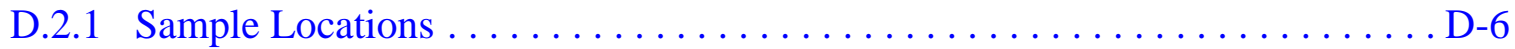

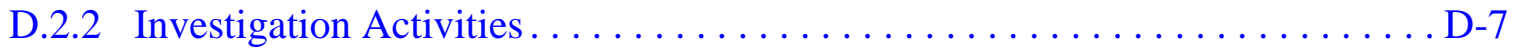

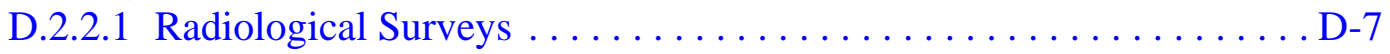

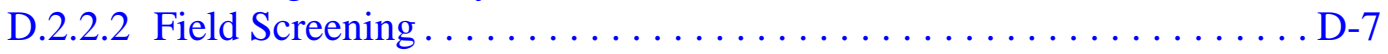

D.2.2.3 Surface and Subsurface Soil Sampling................. D-8

D.2.2.4 Waste Characterization Sampling. .................. D-9

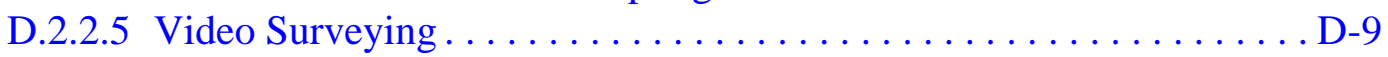

D.2.3 Laboratory Analytical Information. . . . . . . . . . . . . . . . .

D.2.4 Comparison to Action Levels . . . . . . . . . . . . . . . . . . . . D-11

D.3.0 CAS 01-02-01, Underground Storage Tank, Investigation Results . . . . . . . . . . D-12

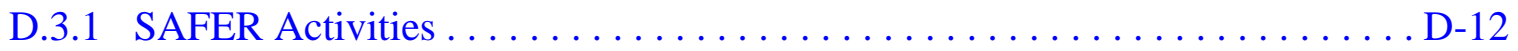

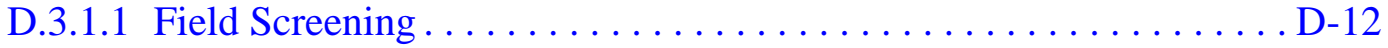

D.3.1.2 Geophysical Results ........................ D-12

D.3.1.3 Radiological Surveys ....................... D-14

D.3.1.4 Visual Inspections........................... D-14

D.3.1.5 Video Surveys............................. D-14

D.3.1.6 Sample Collection............................ D-14

D.3.1.7 Deviations............................... D-15

D.3.2 Investigation Results.............................. D-15

D.3.2.1 Volatile Organic Compounds ...................... D-15

D.3.2.2 Semivolatile Organic Compounds ................... D-15

D.3.2.3 Total Petroleum Hydrocarbons...................... D-16

D.3.2.4 RCRA Metals ............................ D-16

D.3.2.5 Gamma-Emitting Radionuclides $\ldots \ldots \ldots \ldots \ldots \ldots \ldots \ldots$ D-17

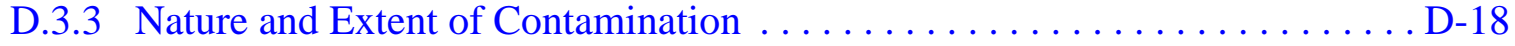

D.3.4 Revised Conceptual Site Model .......................... D-18

D.4.0 CAS 07-02-01, Underground Storage Tanks, Investigation Results ........... D-19

D.4.1 SAFER Activities ....................................

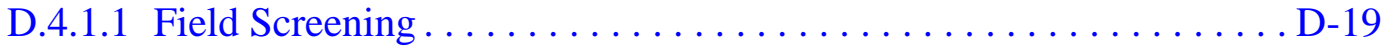

D.4.1.2 Geophysical Results ...................... D-19

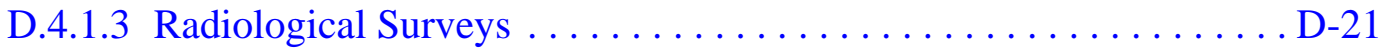

D.4.1.4 Visual Inspections........................... 


\section{Table of Contents (Continued)}

D.4.1.5 Video Surveys. ... . . . . . . . . . . . . . . . . . . D-22

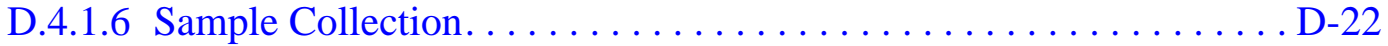

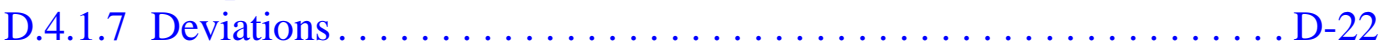

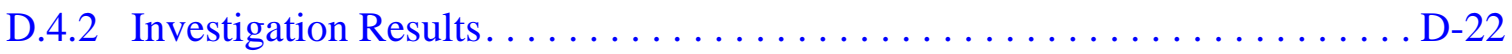

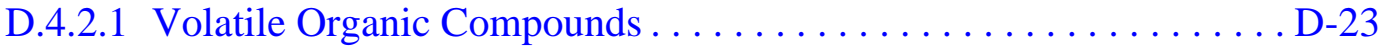

D.4.2.2 Semivolatile Organic Compounds . . . . . . . . . . . . . . . . . D-23

D.4.2.3 Total Petroleum Hydrocarbons. . . . . . . . . . . . . . . . . . . . D-23

D.4.2.4 RCRA Metals . . . . . . . . . . . . . . . . . . . . . . D-24

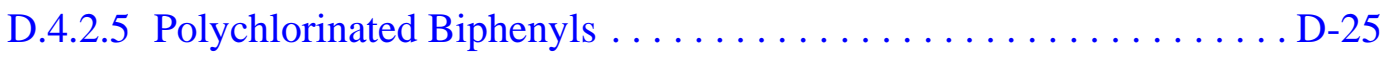

D.4.2.6 Gamma-Emitting Radionuclides . . . . . . . . . . . . . . D-25

D.4.3 Nature and Extent of Contamination . . . . . . . . . . . . . . . . D-25

D.4.4 Revised Conceptual Site Model ..................... D-25

D.5.0 CAS 10-02-01, Underground Storage Tank, Investigation Results . . . . . . . . . . . D-27

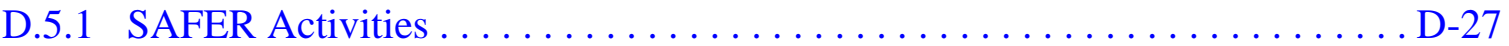

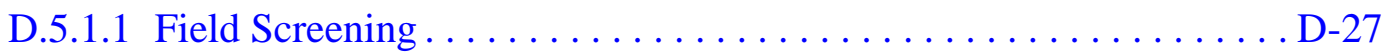

D.5.1.2 Geophysical Results . . . . . . . . . . . . . . . . . D-27

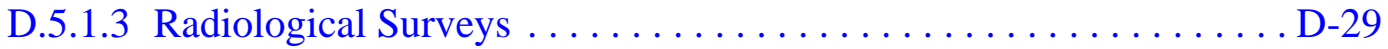

D.5.1.4 Visual Inspections. . . . . . . . . . . . . . . . . . D-29

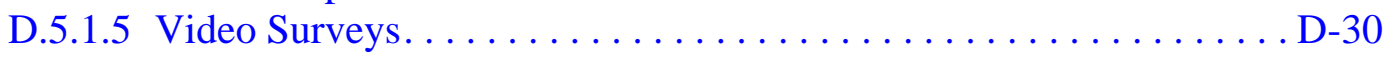

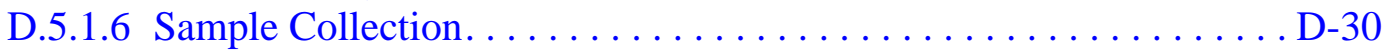

D.5.1.7 Deviations . . . . . . . . . . . . . . . . . . . . D-30

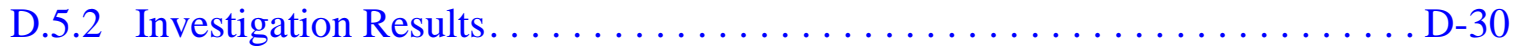

D.5.2.1 Volatile Organic Compounds ................... D-31

D.5.2.2 Semivolatile Organic Compounds . . . . . . . . . . . . . D-31

D.5.2.3 Total Petroleum Hydrocarbons. . . . . . . . . . . . . . . . . . . D-32

D.5.2.4 RCRA Metals . . . . . . . . . . . . . . . . . . . . . D-32

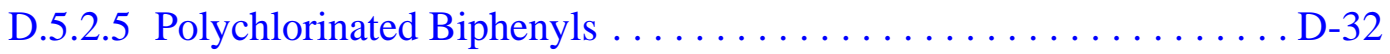

D.5.2.6 Gamma-Emitting Radionuclides . . . . . . . . . . . . . D-33

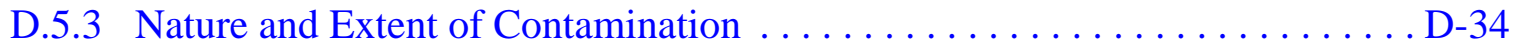

D.5.4 Revised Conceptual Site Model . . . . . . . . . . . . . . . . . . . D-34

D.6.0 CAS 20-02-03, Underground Storage Tank, Investigation Results . . . . . . . . . . . D-35

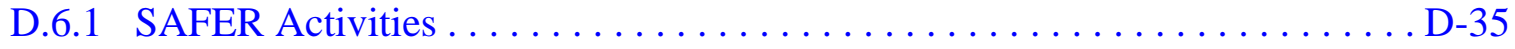

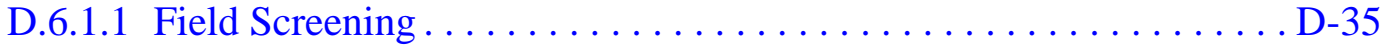

D.6.1.2 Geophysical Results . . . . . . . . . . . . . . . . . D-35

D.6.1.3 Radiological Surveys . . . . . . . . . . . . . . . . . D-37

D.6.1.4 Visual Inspections. . . . . . . . . . . . . . . . . . . D-37

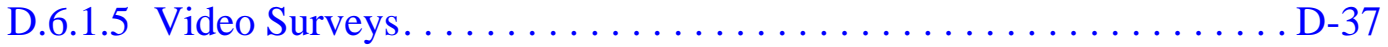

D.6.1.6 Sample Collection. . . . . . . . . . . . . . . . . . . . D-37

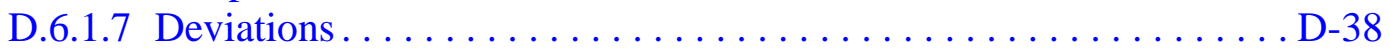




\section{Table of Contents (Continued)}

D.6.2 Investigation Results............................... D-38

D.6.2.1 Volatile Organic Compounds ...................... D-38

D.6.2.2 Semivolatile Organic Compounds .................. D-38

D.6.2.3 Total Petroleum Hydrocarbons..................... D-39

D.6.2.4 RCRA Metals ............................. D-39

D.6.2.5 Gamma-Emitting Radionuclides $\ldots \ldots \ldots \ldots \ldots \ldots \ldots \ldots \ldots$ D-40

D.6.3 Nature and Extent of Contamination ...................... D-40

D.6.4 Revised Conceptual Site Model ............................. D-40

D.7.0 CAS 20-99-05, Tar Residue, Investigation Results ..................... D-41

D.7.1 SAFER Activities . . . . . . . . . . . . . . . . . . . . . . . D-41

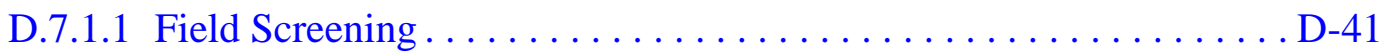

D.7.1.2 Radiological Surveys ....................... D-41

D.7.1.3 Visual Inspections............................ D-41

D.7.1.4 Video Surveys.............................

D.7.1.5 Sample Collection..........................

D.7.1.6 Deviations ................................

D.7.2 Investigation Results................................ .

D.7.2.1 Volatile Organic Compounds ..................... D-44

D.7.2.2 Semivolatile Organic Compounds ................ D-44

D.7.2.3 Total Petroleum Hydrocarbons. . . . . . . . . . . . . . . D-44

D.7.2.4 RCRA Metals ........................... D-45

D.7.3 Nature and Extent of Contamination $\ldots \ldots \ldots \ldots \ldots \ldots \ldots \ldots \ldots \ldots \ldots \ldots$

D.7.4 Revised Conceptual Site Model ........................ D-46

D.8.0 CAS 22-02-02, Buried UST Piping, Investigation Results . . . . . . . . . . . . D-47

D.8.1 SAFER Activities .................................... .

D.8.1.1 Field Screening ..............................

D.8.1.2 Geophysical Results ........................ D-47

D.8.1.3 Radiological Surveys ......................... D-49

D.8.1.4 Visual Inspections............................ D-49

D.8.1.5 Video Surveys............................. D-49

D.8.1.6 Sample Collection......................... D-50

D.8.1.7 Deviations ............................... D-50

D.8.2 Investigation Results................................

D.8.2.1 Volatile Organic Compounds ..................... D-50

D.8.2.2 Semivolatile Organic Compounds ................. D-51

D.8.2.3 Total Petroleum Hydrocarbons....................... D-51

D.8.2.4 RCRA Metals ............................ D-52

D.8.2.5 Gamma-Emitting Radionuclides $\ldots \ldots \ldots \ldots \ldots \ldots \ldots \ldots \ldots$ D-53

D.8.3 Nature and Extent of Contamination $\ldots \ldots \ldots \ldots \ldots \ldots \ldots \ldots \ldots \ldots \ldots \ldots \ldots$ 


\section{Table of Contents (Continued)}

D.8.4 Revised Conceptual Site Model . . . . . . . . . . . . . . . . . . . . . D-53

D.9.0 CAS 23-02-07, Underground Storage Tank, Investigation Results . . . . . . . . . . D-54

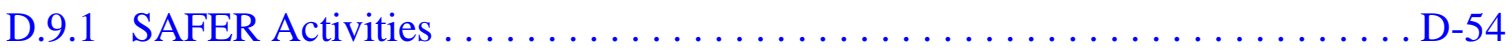

D.9.1.1 Field Screening .............................

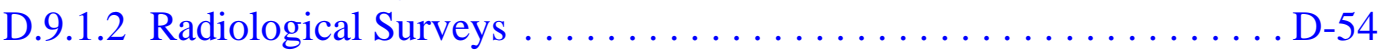

D.9.1.3 Visual Inspections. . . . . . . . . . . . . . . . . . . .

D.9.1.4 Video Surveys........................... D-56

D.9.1.5 Sample Collection.......................... D-56

D.9.1.6 Deviations ............................... D-57

D.9.2 Investigation Results. . . . . . . . . . . . . . . . . . . . . . D-57

D.9.2.1 Volatile Organic Compounds .................... D-57

D.9.2.2 Semivolatile Organic Compounds .................. D-58

D.9.2.3 Total Petroleum Hydrocarbons...................... D-58

D.9.2.4 RCRA Metals ............................ D-59

D.9.2.5 Polychlorinated Biphenyls .................... D-60

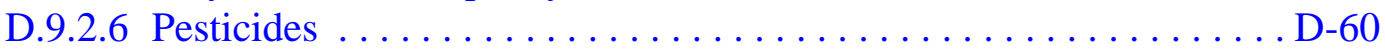

D.9.2.7 Gamma-Emitting Radionuclides .................. D-60

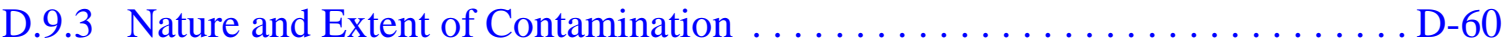

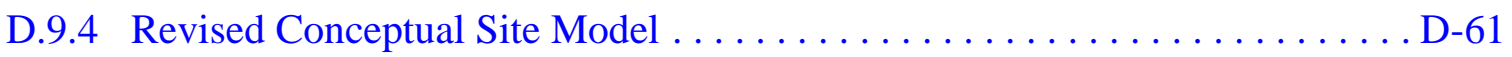

D.10.0 Waste Management................................... D-62

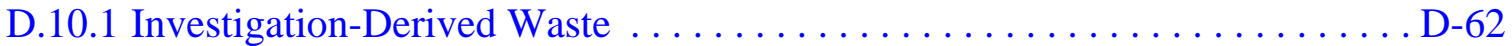

D.10.1.1 Waste Streams .............................

D.10.1.2 Waste Generated $\ldots \ldots \ldots \ldots \ldots \ldots \ldots \ldots \ldots \ldots \ldots \ldots \ldots \ldots \ldots$

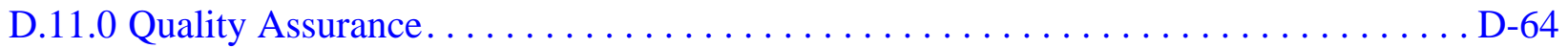

D.11.1 Data Validation.................................. D-64

D.11.1.1Tier I Evaluation. . . . . . . . . . . . . . . . . . . . D-64

D.11.1.2Tier II Evaluation ............................ .

D.11.1.3Tier III Evaluation ......................... D-66

D.11.2 Field QC Samples................................

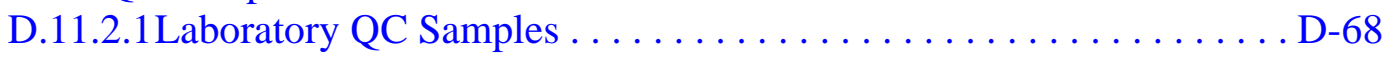

D.11.3 Field Nonconformances ............................. D-69

D.11.4 Laboratory Nonconformances $\ldots \ldots \ldots \ldots \ldots \ldots \ldots \ldots \ldots \ldots . . \ldots \ldots$

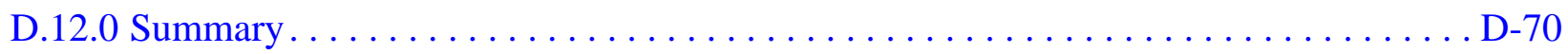

D.13.0 References........................................ D 


\section{Table of Contents (Continued)}

\section{Appendix E - Waste Disposition Documentation}

E.1.0 Waste Disposition Documentation ....................... E-1

\section{Appendix F - Modifications to the Post-Closure Plan}

F.1.0 Modifications to the Post-Closure Plan $\ldots \ldots \ldots \ldots \ldots \ldots \ldots \ldots \ldots \ldots \ldots \ldots$ F-1

\section{Appendix G - Use Restrictions}

G.1.0 Use Restrictions $\ldots \ldots \ldots \ldots \ldots \ldots \ldots \ldots \ldots \ldots \ldots \ldots \ldots \ldots \ldots \ldots \ldots \ldots \ldots \ldots \ldots$

\section{Appendix H - Risk Evaluation}

H.1.0 Risk Assessment . . . . . . . . . . . . . . . . . . . . . . . .

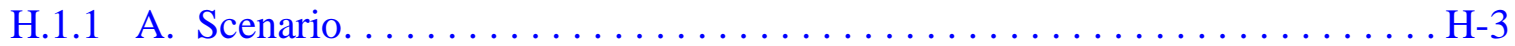

H.1.2 B. Site Assessment. . . . . . . . . . . . . . . . . . . . .

H.1.3 C. Site Classification and Initial Response Action . . . . . . . . . . . . H-12

H.1.4 D. Development of Tier 1 Lookup Table of RBSLs . . . . . . . . . . . . H-12

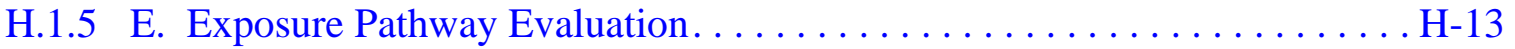

H.1.6 F. Comparison of Site Conditions with Tier 1 RBSLs . . . . . . . . . . . . H-14

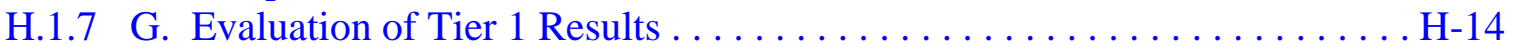

H.1.8 H. Tier 1 Remedial Action Evaluation . . . . . . . . . . . . . . H-14

H.1.9 I. Tier 2 Evaluation . . . . . . . . . . . . . . . . . . . . .

H.1.10 J. Development of Tier 2 SSTLs . . . . . . . . . . . . . . . . H-15

H.1.11 K. Comparison of Site Conditions with Tier 2 SSTLs . . . . . . . . . . H-15

H.1.12 L. Tier 2 Remedial Action Evaluation. . . . . . . . . . . . . . . H-17

H.2.0 Recommendations. . . . . . . . . . . . . . . . . . . . . . . H-18

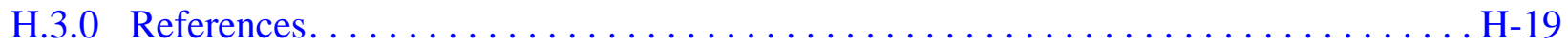

Attachment 1 - Derivation of Residual Radioactive Material Guidelines for Radionuclides in Soil at Corrective Action Unit 130, CAS 10-02-01, Storage Tanks, Nevada Test Site, Nevada

Exhibit 1 - RESRAD Summary Report: CAU 130, CAS 10-02-01

Appendix I - Nevada Division of Environmental Protection Comments 


\section{List of Figures}

Number

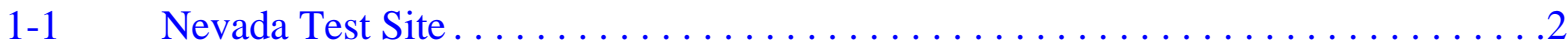

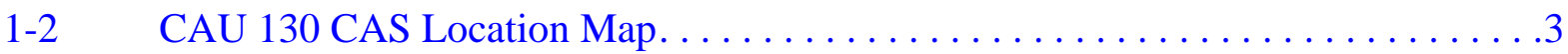

A.2-1 Conceptual Site Model for CAU 130 CASs .................. A-5

A.2-2 Conceptual Site Model Diagram for CAU 130, Storage Tanks ........... A-8

A.3-1 SAFER Closure Decision Process for CAU $130 \ldots \ldots \ldots \ldots \ldots \ldots \ldots$ A-15

A.8-1 Proposed Sample Strategy at CAS 01-02-01 ................ A-35

A.8-2 Proposed Sample Strategy at CAS 07-02-01 ................ A-37

A.8-3 Proposed Sample Strategy at CAS $10-02-01 \ldots \ldots \ldots \ldots \ldots \ldots \ldots$. . . . . . . .

A.8-4 Proposed Sample Strategy at CAS $20-02-03 \ldots \ldots \ldots \ldots \ldots \ldots \ldots \ldots$ A-41

A.8-5 Proposed Sample Strategy at CAS $20-99-05 \ldots \ldots \ldots \ldots \ldots \ldots \ldots$ A-43

A.8-6 Proposed Sample Strategy at CAS 22-02-02 ................. A-45

A.8-7 Proposed Sample Strategy at CAS 23-02-07 . . . . . . . . . . . . . A A-46

D.1-1 CAU 130 CAS Location Map.......................... D-2

D.3-1 Investigation Activities at CAS 01-02-01, Underground Storage Tank...... D-13

D.4-1 Investigation Activities at CAS 07-02-01, Underground Storage Tanks ..... D-20

D.5-1 Investigation Activities at CAS 10-02-01, Underground Storage Tank. . . . . . D-28

D.6-1 Investigation Activities at CAS 20-02-03, Underground Storage Tank...... D-36

D.7-1 Investigation Activities at CAS 20-99-05, Tar Residue ............ D-42

D.8-1 Investigation Activities at CAS 22-02-02, Buried UST Piping $\ldots \ldots \ldots \ldots$ D-48

D.9-1 Investigation Activities at CAS 23-02-07, Underground Storage Tank...... D-55

H.1-1 Risk-Based Corrective Action Decision Process $\ldots \ldots \ldots \ldots \ldots \ldots \ldots . . . . .6$ 


\section{List of Tables}

Number

Title

Page

2-1 CAI Activities Conducted at Each CAS To Meet SAFER Plan

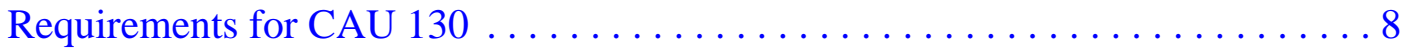

2-2 Samples Collected at CAS 01-02-01, Underground Storage Tank . . . . . . . 10

2-3 Samples Collected at CAS 07-02-01, Underground Storage Tanks. . . . . . . . . 11

2-4 Samples Collected at CAS 10-02-01, Underground Storage Tank . . . . . . . . 12

2-5 Samples Collected at CAS 20-02-03, Underground Storage Tank . . . . . . . . 13

2-6 Samples Collected at CAS 20-99-05, Tar Residue. . . . . . . . . . . . . . . 13

2-7 Samples Collected at CAS 22-02-02, Buried UST Piping . . . . . . . . . . . . 14

2-8 Samples Collected at CAS 23-02-07, Underground Storage Tank . . . . . . . . 15

2-9 Corrective Action Schedule for CAU $130 \ldots \ldots \ldots \ldots \ldots \ldots \ldots \ldots$

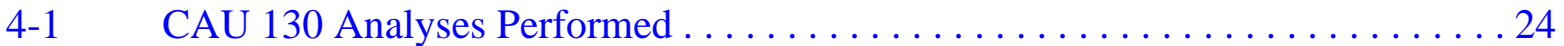

4-2 Analytes Failing Sensitivity Criteria for CAU $130 \ldots \ldots \ldots \ldots \ldots \ldots$

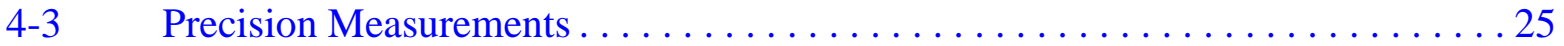

4-4 Accuracy Measurements. . . . . . . . . . . . . . . . . 26

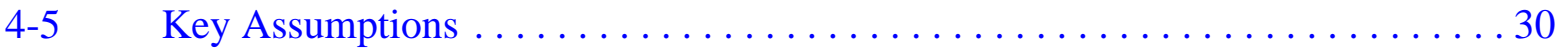

A.2-1 Conceptual Site Model Description of Elements for Each CAS in CAU 130 . . A-6

A.2-2 Analytical Program (Includes Waste Characterization Analyses) . . . . . . . . . A-10

A.2-3 Targeted Contaminants for CAU $130 \ldots \ldots \ldots \ldots \ldots \ldots \ldots \ldots \ldots \ldots \ldots \ldots \ldots \ldots$

A.2-4 Land Use and Exposure Scenarios . . . . . . . . . . . . . . A-13

A.5-1 Spatial Boundaries of CAU 130 CASs . . . . . . . . . . . . . . A-23 


\section{List of Tables (Continued)}

Number

Title

Page

A.5-2 Practical Constraints for the CAU 130 Field Investigation . . . . . . . . . . . A-24

D.2-1 CAI Activities Conducted at Each CAS To Meet SAFER Plan

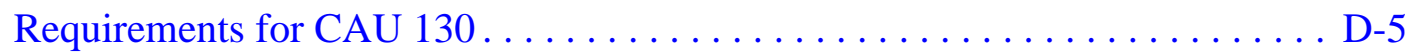

D.2-2 Laboratory Analyses and Methods, CAU 130 Investigation Samples ...... D-10

D.3-1 Samples Collected at CAS 01-02-01, Underground Storage Tank . . . . . . . . D-14

D.3-2 Sample Results for SVOCs Detected above MDCs at CAS 01-02-01, Underground Storage Tank ............................ D-16

D.3-3 Sample Results for TPH-DRO Detected above MDCs at CAS 01-02-01, Underground Storage Tank ................ D-16

D.3-4 Sample Results for RCRA Metals Detected above MDCs at CAS 01-02-01, Underground Storage Tank ............... D-17

D.3-5 Sample Results for Gamma-Emitting Radionuclides Detected above MDCs at CAS 01-02-01, Underground Storage Tank ......... D-17

D.4-1 Samples Collected at CAS 07-02-01, Underground Storage Tanks ....... D-21

D.4-2 Sample Results for Total VOCs Detected above MDCs at CAS 07-02-01, Underground Storage Tanks................ D-23

D.4-3 Sample Results for TPH-DRO and -GRO Detected above MDCs at CAS 07-02-01, Underground Storage Tanks................. D-24

D.4-4 Sample Results for RCRA Metals Detected above MDCs at CAS 07-02-01, Underground Storage Tanks................. D-24

D.4-5 Sample Results for PCBs Detected above MDCs at CAS 07-02-01, Underground Storage Tanks ........................... D-25

D.4-6 Sample Results for Gamma-Emitting Radionuclides Detected above MDCs at CAS 07-02-01, Underground Storage Tanks.......... D-26 


\section{List of Tables (Continued)}

Number

Title

Page

D.5-1 Samples Collected at CAS 10-02-01, Underground Storage Tank . . . . . . . . D-29

D.5-2 Sample Results for VOCs Detected above MDCs at CAS 10-02-01, Underground Storage Tank ........................... D-31

D.5-3 Sample Results for SVOCs Detected above MDCs at CAS 10-02-01, Underground Storage Tank ............................ D-31

D.5-4 Sample Results for TPH-DRO and -GRO Detected above MDCs at CAS 10-02-01, Underground Storage Tank ................. D-32

D.5-5 Sample Results for RCRA Metals Detected above MDCs at CAS 10-02-01, Underground Storage Tank . . . . . . . . . . . . D-33

D.5-6 Sample Results for Gamma-Emitting Radionuclides Detected above MDCs at CAS 10-02-01, Underground Storage Tank .......... D-34

D.6-1 Samples Collected at CAS 20-02-03, Underground Storage Tank ........ . D-37

D.6-2 Sample Results for TPH-DRO Detected above MDCs at CAS 20-02-03, Underground Storage Tank ............... D-39

D.6-3 Sample Results for RCRA Metals Detected above MDCs at CAS 20-02-03, Underground Storage Tank ................. D-39

D.6-4 Sample Results for Gamma-Emitting Radionuclides Detected above MDCs at CAS 20-02-03, Underground Storage Tank ........... D-40

D.7-1 Samples Collected at CAS 20-99-05, Tar Residue $\ldots \ldots \ldots \ldots \ldots \ldots$ D-43

D.7-2 Sample Results for Total SVOCs Detected above MDCs at CAS 20-99-05, Tar Residue........................... D-45

D.7-3 Sample Results for TPH-DRO Detected above MDCs at CAS 20-99-05, Tar Residue.......................... D-45

D.7-4 Sample Results for RCRA Metals Detected above MDCs at CAS 20-99-05, Tar Residue......................... D-46 


\section{List of Tables (Continued)}

Number

Title

Page

D.8-1 Samples Collected at CAS 22-02-02, Buried UST Piping . . . . . . . . . . . D-49

D.8-2 Sample Results for Total VOCs Detected above MDCs at CAS 22-02-02, Buried UST Piping . . . . . . . . . . . . . . . . D-51

D.8-3 Sample Results for Total SVOCs Detected above MDCs at CAS 22-02-02, Buried UST Piping . . . . . . . . . . . . . . . . . .

D.8-4 Sample Results for TPH-DRO Detected above MDCs at CAS 22-02-02, Buried UST Piping . . . . . . . . . . . . . . . . .

D.8-5 Sample Results for RCRA Metals Detected above MDCs at CAS 22-02-02, Buried UST Piping. . . . . . . . . . . . . . . .

D.8-6 Sample Results for Gamma-Emitting Radionuclides Detected above MDCs at CAS 22-02-02, Buried UST Piping. . . . . . . . . . . D-53

D.9-1 Samples Collected at CAS 23-02-07, Underground Storage Tank ........ D-56

D.9-2 Sample Results for Total VOCs Detected above MDCs at CAS 23-02-07, Underground Storage Tank .............. D-58

D.9-3 Sample Results for Total SVOCs Detected above MDCs at CAS 23-02-07, Underground Storage Tank ................ D-58

D.9-4 Sample Results for TPH-DRO and -GRO Detected above MDCs at CAS 23-02-07, Underground Storage Tank ................ D-59

D.9-5 Sample Results for RCRA Metals Detected above MDCs at CAS 23-02-07, Underground Storage Tank ................. D-59

D.9-6 Sample Results for Pesticides Detected above MDCs at CAS 23-02-07, Underground Storage Tank .......................... D-60

D.9-7 Sample Results for Gamma-Emitting Radionuclides Detected above MDCs at CAS 23-02-07, Underground Storage Tank . . D-61 


\section{List of Tables (Continued)}

Number

Title

Page

H.1-1 CAI Activities Conducted at Each CAS To Meet SAFER Plan

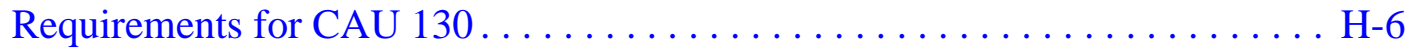

H.1-2 Maximum Concentration of Detected Contaminants for CAS 01-02-01, Underground Storage Tank ............................ H-6

H.1-3 Maximum Concentration of Detected Contaminants for CAS 07-02-01, Underground Storage Tanks ........................... H-7

H.1-4 Maximum Concentration of Detected Contaminants for CAS 10-02-01, Underground Storage Tank ........................... H-8

H.1-5 Maximum Concentration of Detected Contaminants for CAS 20-02-03, Underground Storage Tank ........................... H-9

H.1-6 Maximum Concentration of Detected Contaminants for CAS 20-99-05, Tar Residue .................................. H-10

H.1-7 Maximum Concentration of Detected Contaminants for CAS 22-02-02, Buried UST Piping. ................................ H-10

H.1-8 Maximum Concentration of Detected Contaminants for CAS 23-02-07, Underground Storage Tank ........................... H-11

H.1-9 Maximum Reported Value for Tier 1 Comparison $\ldots \ldots \ldots \ldots \ldots \ldots \ldots$ H-14

H.1-10 Tier 2 SSTLs and CAU 130 Results for Hazardous Constituents of Diesel for Sample 130G001 ........................ H-16 


\section{List of Acronyms and Abbreviations}

Ac

ALARA

Am

ARL/SORD

ASTM

bgs

BMP

C

CAI

CAS

CAU

$\mathrm{Cl}$

CLP

Co

COC

COPC

$\mathrm{CR}$

Cs

CSM

$\mathrm{CZ}$

DOE

$\mathrm{dpm} / 100 \mathrm{~cm}^{2}$

DQA

DQI

DQO

DRO
Actinium

As low as reasonably achievable

Americium

Air Resources Laboratory/Special Operations and Research Division

American Society for Testing and Materials

Below ground surface

Best management practice

Carbon

Corrective action investigation

Corrective action site

Corrective action unit

Chlorine

Contract Laboratory Program

Cobalt

Contaminant of concern

Contaminant of potential concern

Closure report

Cesium

Conceptual site model

Contamination zone

U.S. Department of Energy

Disintegrations per minute per 100 square centimeters

Data quality assessment

Data quality indicator

Data quality objective

Diesel-range organics 


\section{List of Acronyms and Abbreviations (Continued)}

\begin{tabular}{|c|c|}
\hline EERF & Eastern Environmental Radiation Facility \\
\hline EML & Environmental Measurements Laboratory \\
\hline EPA & U.S. Environmental Protection Agency \\
\hline EPC & Exposure point concentration \\
\hline $\mathrm{Eu}$ & Europium \\
\hline FAL & Final action level \\
\hline FD & Field duplicate \\
\hline $\mathrm{Fe}$ & Iron \\
\hline FFACO & Federal Facility Agreement and Consent Order \\
\hline FSL & Field-screening level \\
\hline FSR & Field-screening result \\
\hline $\mathrm{ft}$ & Foot \\
\hline $\mathrm{g} / \mathrm{m}^{3}$ & Grams per cubic meter \\
\hline g/yr & Grams per year \\
\hline gal & Gallon \\
\hline GPS & Global Positioning System \\
\hline GRO & Gasoline-range organics \\
\hline HASL & Health and Safety Laboratory \\
\hline ID & Identification \\
\hline IDW & Investigation-derived waste \\
\hline in. & Inch \\
\hline LCS & Laboratory control sample \\
\hline $\mathrm{m}$ & Meter \\
\hline $\mathrm{m} / \mathrm{sec}$ & Meters per second \\
\hline $\mathrm{m} / \mathrm{yr}$ & Meters per year \\
\hline $\mathrm{m}^{2}$ & Square meter \\
\hline
\end{tabular}




\section{List of Acronyms and Abbreviations (Continued)}

\begin{tabular}{|c|c|}
\hline $\mathrm{M} \& \mathrm{O}$ & Management and operating \\
\hline MDC & Minimum detectable concentration \\
\hline $\mathrm{mg} / \mathrm{kg}$ & Milligrams per kilogram \\
\hline mrem & Millirem \\
\hline $\mathrm{mrem} / \mathrm{yr}$ & Millirem per year \\
\hline MS & Matrix spike \\
\hline MSD & Matrix spike duplicate \\
\hline N/A & Not applicable \\
\hline NAC & Nevada Administrative Code \\
\hline NAD & North American Datum \\
\hline ND & Nondetect \\
\hline NDEP & Nevada Division of Environmental Protection \\
\hline NFA & No further action \\
\hline $\mathrm{Ni}$ & Nickel \\
\hline $\mathrm{NIOSH}$ & National Institute for Occupational Safety and Health \\
\hline NIST & National Institute of Standards and Technology \\
\hline NNSA/NSO & $\begin{array}{l}\text { U.S. Department of Energy, National Nuclear Security Administration } \\
\text { Nevada Site Office }\end{array}$ \\
\hline NSTec & National Security Technologies, LLC \\
\hline NTS & Nevada Test Site \\
\hline PAL & Preliminary action level \\
\hline $\mathrm{Pb}$ & Lead \\
\hline $\mathrm{PB}$ & Preparation blank \\
\hline PCB & Polychlorinated biphenyl \\
\hline $\mathrm{pCi} / \mathrm{g}$ & Picocuries per gram \\
\hline POC & Performance objective criteria \\
\hline PPE & Personal protective equipment \\
\hline
\end{tabular}




\section{List of Acronyms and Abbreviations (Continued)}

\begin{tabular}{|c|c|}
\hline ppm & Parts per million \\
\hline PRG & Preliminary Remediation Goal \\
\hline PSM & Potential source material \\
\hline $\mathrm{Pu}$ & Plutonium \\
\hline QA & Quality assurance \\
\hline QAPP & Quality Assurance Project Plan \\
\hline QC & Quality control \\
\hline $\mathrm{Ra}$ & Radium \\
\hline RadCon & Radiological Control \\
\hline RBCA & Risk-based corrective action \\
\hline RBSL & Risk-based screening level \\
\hline RCRA & Resource Conservation and Recovery Act \\
\hline RESL & Radiological and Environmental Sciences Laboratory \\
\hline RESRAD & Residual radioactive \\
\hline RPD & Relative percent difference \\
\hline SAFER & Streamlined Approach for Environmental Restoration \\
\hline SCL & Sample collection log \\
\hline SDG & Sample delivery group \\
\hline SNJV & Stoller-Navarro Joint Venture \\
\hline $\mathrm{Sr}$ & Strontium \\
\hline SSTL & Site-specific target level \\
\hline SVOC & Semivolatile organic compound \\
\hline TCLP & Toxicity Characteristic Leaching Procedure \\
\hline TEDE & Total effective dose equivalent \\
\hline Th & Thorium \\
\hline $\mathrm{Tl}$ & Thallium \\
\hline
\end{tabular}




\section{List of Acronyms and Abbreviations (Continued)}

TPH Total petroleum hydrocarbons

U Uranium

UCL Upper confidence limit

UR Use restriction

UST Underground storage tank

UTM Universal Transverse Mercator

VOC Volatile organic compound

$\mathrm{yd}^{3} \quad$ Cubic yard

yr Year

\%R Percent recovery 


\section{Executive Summary}

This Closure Report (CR) presents information supporting the closure of Corrective Action Unit (CAU) 130: Storage Tanks, Nevada Test Site, Nevada. This CR complies with the requirements of the Federal Facility Agreement and Consent Order that was agreed to by the State of Nevada; U.S. Department of Energy (DOE), Environmental Management; U.S. Department of Defense; and DOE, Legacy Management. The corrective action sites (CASs) within CAU 130 are located within Areas 1, 7, 10, 20, 22, and 23 of the Nevada Test Site. Corrective Action Unit 130 is comprised of the following CASs:

- 01-02-01, Underground Storage Tank

- 07-02-01, Underground Storage Tanks

- 10-02-01, Underground Storage Tank

- 20-02-03, Underground Storage Tank

- 20-99-05, Tar Residue

- 22-02-02, Buried UST Piping

- 23-02-07, Underground Storage Tank

This CR provides documentation supporting the completed corrective action investigations and provides data confirming that the closure objectives for CASs within CAU 130 were met. To achieve this, the following actions were performed:

- Reviewed the current site conditions, including the concentration and extent of contamination.

- Implemented any corrective actions necessary to protect human health and the environment.

- Properly disposed of corrective action and investigation-derived wastes.

From August 4 through September 30, 2008, closure activities were performed as set forth in the Streamlined Approach for Environmental Restoration Plan for CAU 130, Storage Tanks, Nevada Test Site, Nevada. The purposes of the activities as defined during the data quality objectives process were:

- Determine whether contaminants of concern (COCs) are present.

- If COCs are present, determine their nature and extent, implement appropriate corrective actions, confirm that no residual contamination is present, and properly dispose of wastes. 
Constituents detected during the closure activities were evaluated against final action levels to identify COCs for CAU 130. Assessment of the data generated from closure activities indicates that no further action is necessary because no COCs were identified at any CAU 130 CAS. Debris removal from these CASs was considered a best management practice because no contamination was detected.

The DOE, National Nuclear Security Administration Nevada Site Office provides the following recommendations:

- No further corrective action is required at all CAU 130 CASs.

- A Notice of Completion to DOE, National Nuclear Security Administration Nevada Site Office, is requested from the Nevada Division of Environmental Protection for closure of CAU 130.

- Corrective Action Unit 130 should be moved from Appendix III to Appendix IV of the Federal Facility Agreement and Consent Order. 
This Closure Report (CR) presents information supporting closure of Corrective Action Unit (CAU) 130: Storage Tanks, Nevada Test Site (NTS), Nevada. This complies with the requirements of the Federal Facility Agreement and Consent Order (FFACO) that was agreed to by the State of Nevada; U.S. Department of Energy (DOE), Environmental Management; U.S. Department of Defense; and DOE, Legacy Management (FFACO, 1996; as amended February 2008). Corrective Action Unit 130 contains corrective action sites (CASs) located in Areas 1, 7, 10, 20, 22, and 23 of the NTS. The NTS is located approximately 65 miles northwest of Las Vegas, Nevada (Figure 1-1).

Corrective Action Unit 130 is comprised of the seven CASs that are shown on Figure 1-2 and listed below:

- 01-02-01, Underground Storage Tank

- 07-02-01, Underground Storage Tanks

- 10-02-01, Underground Storage Tank

- 20-02-03, Underground Storage Tank

- 20-99-05, Tar Residue

- 22-02-02, Buried UST Piping

- 23-02-07, Underground Storage Tank

\subsection{Purpose}

This CR provides documentation and justification for the closure of CAU 130 without further corrective action. This justification is based on process knowledge and the results of the investigative activities conducted in accordance with the Streamlined Approach for Environmental Restoration (SAFER) Plan for Corrective Action Unit 130: Storage Tanks (NNSA/NSO, 2008). The SAFER Plan provides information relating to site history as well as the scope and planning of the corrective action investigation (CAI). Therefore, this information will not be repeated in this CR.

\subsection{Scope}

The closure actions of clean closure and no further action (NFA) were completed as demonstrated by environmental sample analytical results using judgmental sampling that contaminants of 


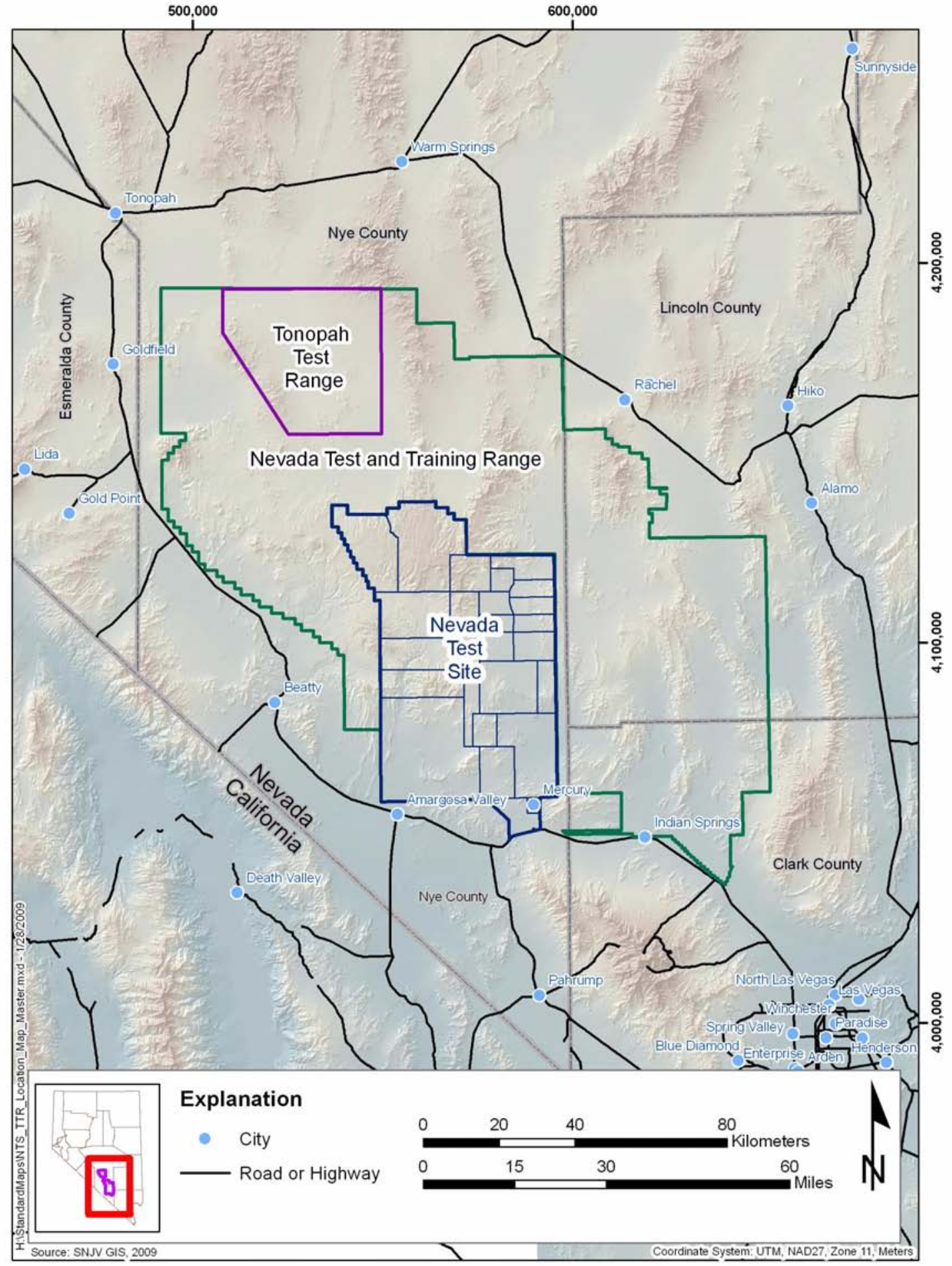

Figure 1-1

Nevada Test Site 


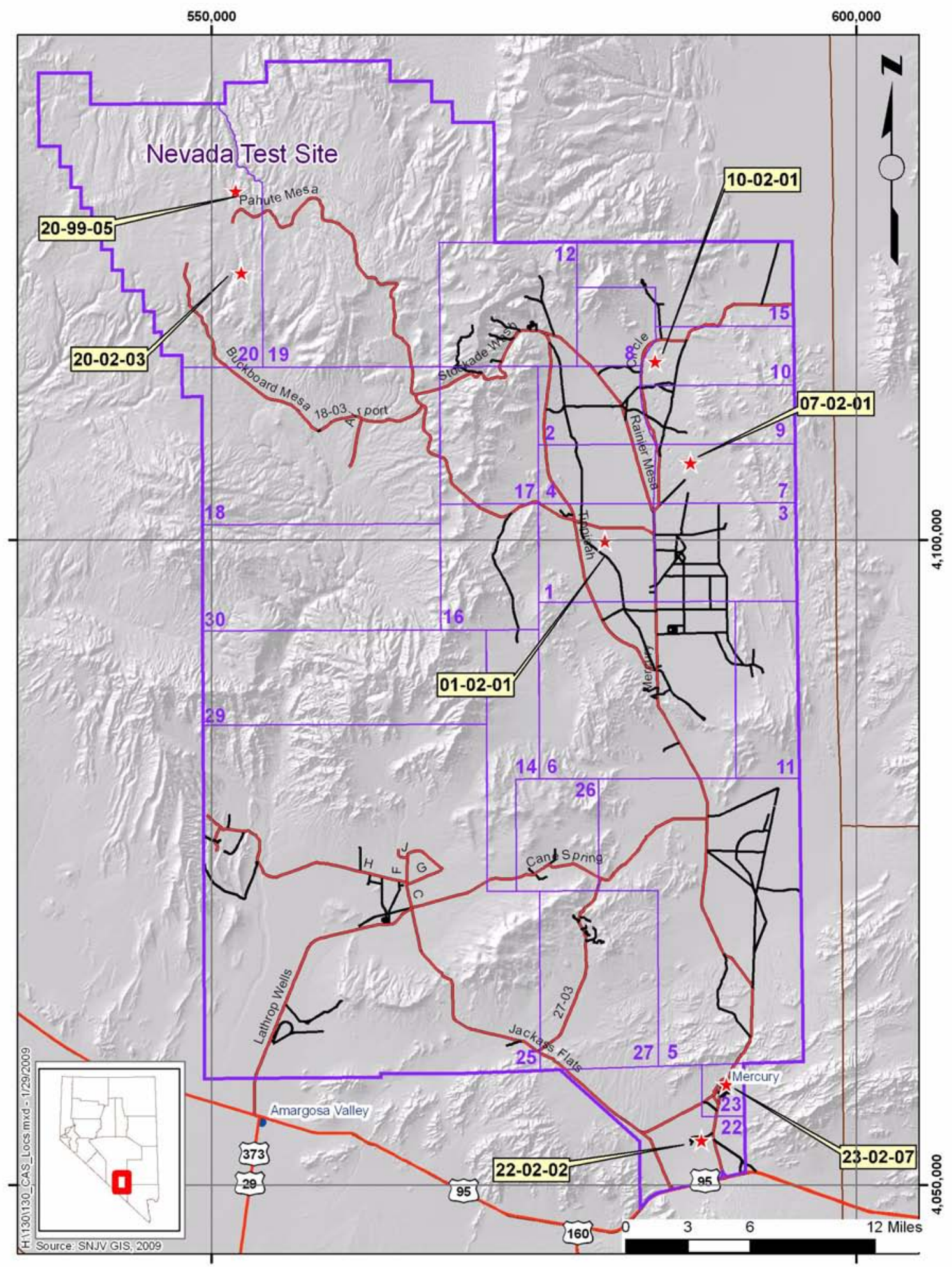

Figure 1-2

CAU 130 CAS Location Map 
concern (COCs) do not exist within the CASs. Activities used to implement these corrective actions included the following:

- Removing surface debris and/or materials to facilitate sampling.

- Performing radiological surveys.

- Performing field screening.

- Video recording of selected features.

- Collecting environmental samples for laboratory analysis.

- Collecting waste management samples.

- Collecting quality control (QC) samples.

- Performing best management practices of debris removal at various CASs.

\subsection{Closure Report Contents}

This CR is divided into the following sections and appendices:

Section 1.0 - Introduction: Summarizes the purpose, scope, and contents of this CR.

Section 2.0 - Closure Activities: Summarizes the closure activities, deviations from the approved SAFER Plan, and the actual schedule.

Section 3.0 - Waste Disposition: Discusses the wastes generated and disposed in approved waste management facilities.

Section 4.0 - Closure Verification Results: Describes verification activities and results.

Section 5.0 - Conclusions and Recommendations: Provides the conclusions and recommendations along with the rationale for their determination.

Section 6.0 - References: Provides a list of all referenced documents used in the preparation of this CR.

Appendix A - Data Quality Objectives (DQOs) as Developed in the SAFER Plan: Provides the DQOs as presented in Appendix B of the CAU 130 SAFER Plan.

Appendix B - Closure Certification: Documents the specific closure activities completed for each CAS within CAU 130. 
Appendix C - As-Built Documentation: Identifies the as-built drawings for each CAS.

Appendix D - Confirmation Sampling Test Results: Provides a description of the project objectives, field closure and sampling activities, and closure results.

Appendix E - Waste Disposition Documentation: Documents disposal of items removed during closure activities.

Appendix F - Modifications to the Post-Closure Plan: Documents any modifications to the Post-Closure Plan.

Appendix G - Use Restrictions: Documents the use restrictions (URs), if required.

Appendix H - Risk Evaluation: Presents the risk assessment results.

Appendix I - Nevada Division of Environmental Protection (NDEP) comments.

\subsubsection{Applicable Programmatic Plans and Documents}

To ensure all project objectives, health and safety requirements, and QC procedures were adhered to, all closure activities were performed in accordance with the following documents:

- Streamlined Approach for Environmental Restoration Plan for CAU 130: Storage Tanks, Nevada Test Site, Nevada (NNSA/NSO, 2008)

- $\quad$ Industrial Sites Quality Assurance Project Plan (QAPP) (NNSA/NV, 2002)

- Federal Facility Agreement and Consent Order (1996, as amended February 2008)

- Approved standard operating procedures

\subsubsection{Data Quality Objectives}

This section contains a summary of the DQO process that is presented in Appendix A. The DQOs were developed to identify data needs, clearly define the intended use of the environmental data, and design a data collection program that will satisfy these purposes. 
The problem statement for CAU 130 is: "Existing information on the nature and extent of potential contamination is insufficient to validate the assumptions used to select the corrective actions and to verify that closure objectives were met for the CASs in CAU 130.” To address this problem, the resolution of two decision statements is required:

- Decision I: “Is any COC present in environmental media within the CAS?” For the judgmental sampling design, any contaminant associated with a release from the CAS that is remaining at concentrations exceeding its corresponding final action level (FAL) will be defined as a COC.

- Decision II: “Is sufficient information available to meet the closure objectives?” Sufficient information is defined to include:

- Identifying the lateral and vertical extent of COC contamination in media, if present.

- The information needed to characterize wastes for disposal.

The presence of a COC would require a corrective action. A corrective action may also be necessary if there is a potential for wastes that are present at a site (i.e., potential source material [PSM]) to release COCs into site environmental media.

To evaluate PSM for the potential to result in the introduction of a COC to the surrounding environmental media, the following conservative assumptions were made:

- Any physical waste containment would fail at some point, and the contents would be released to the surrounding media.

- The resulting concentration of contaminants in the surrounding media would be equal to the concentration of contaminants in the waste.

- Any liquid waste containing a contaminant exceeding the Resource Conservation and Recovery Act (RCRA) toxicity characteristic concentration would cause a COC to be present in the surrounding media if the liquid were released.

- Any non-liquid waste containing a contaminant exceeding an equivalent FAL concentration would cause a COC to be present in the surrounding media.

\subsubsection{Data Quality Assessment Summary}

The data quality assessment (DQA) presented in Section 4.1 includes an evaluation of the data quality indicators (DQIs) to determine the degree of acceptability and usability of the reported data in the 
decision-making process. The DQO process ensures that the right type, quality, and quantity of data will be available to support the resolution of those decisions at an appropriate level of confidence. Using both the DQO and DQA processes help to ensure that DQO decisions are sound and defensible.

The DQA process as presented in Section 4.1 is comprised of the following steps:

- Step 1: Review DQOs and Sampling Design.

- Step 2: Conduct a Preliminary Data Review.

- Step 3: Select the Test.

- Step 4: Verify the Assumptions.

- Step 5: Draw Conclusions from the Data.

Based on the results of the DQA presented in Section 4.1, the information generated during the CAI supports the conceptual site model (CSM) assumptions, and the data collected meet the DQOs and support their intended use in the decision-making process. 


\subsection{Closure Activities}

The following sections summarize the CAU 130 closure activities and any deviations from the original scope of work. Results of confirmation sampling for individual CAU 130 CASs are presented in Appendix D of this document.

\subsection{Description of CAl Activities}

The CAI activities were conducted in accordance with the requirements set forth in the CAU 130 SAFER Plan (NNSA/NSO, 2008). Table 2-1 lists the CAI activities that were conducted at each of the CASs.

Table 2-1

CAl Activities Conducted at Each CAS To Meet SAFER Plan Requirements for CAU 130

\begin{tabular}{|c|c|c|c|c|c|c|c|}
\hline \multirow[b]{2}{*}{ CAl Activities } & \multicolumn{7}{|c|}{ CAS } \\
\hline & 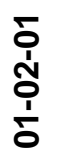 & 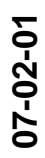 & $\begin{array}{l}\text { 엄 } \\
\text { Ǹ } \\
\text { ò }\end{array}$ & 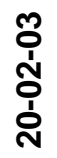 & $\begin{array}{l}\text { 오 } \\
\text { ò } \\
\text { ợ } \\
\text { 워 }\end{array}$ & $\begin{array}{l}\text { Oे } \\
\stackrel{1}{ } \\
\text { Ò. } \\
\text { Ñ }\end{array}$ & 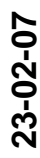 \\
\hline Inspected and verified the CAS components identified in the SAFER Plan. & $\mathrm{X}$ & $\mathrm{X}$ & $\bar{x}$ & $\mathrm{X}$ & $\mathrm{X}$ & $\mathrm{X}$ & $\mathrm{X}$ \\
\hline Performed site walkovers to identify biased sampling locations. & $\mathrm{X}$ & $\mathrm{X}$ & $\mathrm{X}$ & $\mathrm{X}$ & $x$ & $\mathrm{X}$ & $\mathrm{X}$ \\
\hline Conducted surface radiological surveys. & $\mathrm{X}$ & $\mathrm{X}$ & $x$ & $\mathrm{X}$ & $\mathrm{X}$ & $\mathrm{X}$ & -- \\
\hline Performed site transects/walkover surveys. & $\mathrm{x}$ & $x$ & $x$ & $\mathrm{x}$ & -- & -- & -- \\
\hline Conducted geophysical/utility surveys. & $\mathrm{X}$ & $\mathrm{X}$ & $\mathrm{X}$ & $\mathrm{X}$ & -- & $x$ & $\mathrm{X}$ \\
\hline Performed video investigation. & -- & $x$ & -- & -- & -- & -- & -- \\
\hline Collected biased soil samples. & $\mathrm{X}$ & $\mathrm{X}$ & $x$ & $\mathrm{X}$ & $x$ & $\mathrm{X}$ & $\mathrm{X}$ \\
\hline Field screened samples for alpha and beta/gamma radiation. & $x$ & $x$ & $\mathrm{X}$ & $\mathrm{X}$ & $\mathrm{X}$ & $\mathrm{X}$ & $\mathrm{X}$ \\
\hline Collected samples for waste characterization. & -- & $\mathrm{X}$ & $\mathrm{X}$ & -- & $\mathrm{X}$ & -- & $\mathrm{X}$ \\
\hline Collected swipe samples for removable radioactivity determination. & -- & $x$ & $\mathrm{X}$ & -- & $x$ & $x$ & -- \\
\hline Submitted select samples for offsite laboratory analysis. & $\mathrm{X}$ & $\mathrm{x}$ & $x$ & $x$ & $x$ & $x$ & $X$ \\
\hline $\begin{array}{l}\text { Collected Global Positioning System (GPS) coordinates for sample } \\
\text { locations and points of interest. }\end{array}$ & $x$ & $x$ & $X$ & $X$ & $x$ & $x$ & $X$ \\
\hline
\end{tabular}

-- = Not applicable 
Closure verification samples were collected from potential contaminant sources, surface soils, and subsurface soils. Surface soil samples were collected using grab sampling techniques. Subsurface soil samples were collected using a backhoe. The collected soil samples were field screened for volatile organic compounds (VOCs), and alpha and beta/gamma radiation. The results were compared against screening levels to guide in the selection of CAS-specific verification sample locations. Resultant samples were shipped to offsite laboratories to be analyzed for selected chemical and radiological parameters identified in the SAFER Plan (NNSA/NSO, 2008).

The judgmental sampling schemes were implemented to select sample locations and evaluate analytical results, as outlined in the SAFER Plan. These locations were determined during the planning process to be the most likely locations of potential contamination if it were present. Judgmental sampling allows the methodical selection of sample locations that target the populations of interest (defined in the DQOs).

For the judgmental sampling scheme, individual sample results (rather than average concentrations) were used to compare to FALs. Therefore, statistical methods to generate site characteristics (averages) were not necessary. If good historical information is available on the target site of interest, then the sampling may be designed to collect samples only from areas known to have the highest concentration levels on the target site. If the observed concentrations from these samples are below the action level, then a decision can be supported that the site contains safe levels of the contaminant without the samples being truly representative of the entire area (EPA, 2006). The judgmental sampling design was used to determine the existence of contamination at specific locations. Confidence in the judgmental sampling scheme decisions was established qualitatively by the validation of the CSM and justification that sampling locations are the most likely locations to contain a COC, if a COC exists.

\subsubsection{CAS 01-02-01 Closure Activities}

The excavation revealed no underground storage tank (UST) in CAS 01-02-01. A natural gas underground distribution system exists between Buildings 1-31.1e1 and 1-31.4b1. Confirmation samples were collected to meet the requirements of the SAFER Plan. The sample identifications (IDs), locations, types, and analyses are listed in Table 2-2. The analytical results confirm that no COCs were present. Best management practices (BMPs) were completed by filling 
Table 2-2

Samples Collected at CAS 01-02-01, Underground Storage Tank

\begin{tabular}{|c|c|c|c|c|c|c|c|c|c|c|}
\hline $\begin{array}{l}\text { Sample } \\
\text { Location }\end{array}$ & $\begin{array}{l}\text { Sample } \\
\text { Number }\end{array}$ & $\begin{array}{c}\text { Depth } \\
\text { (ft bgs) }\end{array}$ & Matrix & Purpose & $\begin{array}{l}\text { 움 } \\
\text { 号 }\end{array}$ & 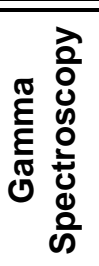 & $\begin{array}{l}\text { O } \\
\text { 寽 }\end{array}$ & 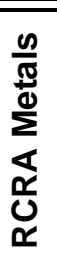 & 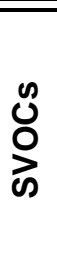 & $\begin{array}{l}\mathscr{y} \\
\text { O }\end{array}$ \\
\hline $\mathrm{A} 01$ & $130 \mathrm{~A} 001$ & $0.0-0.5$ & Soil & Environmental & $\mathrm{X}$ & $x$ & $x$ & $x$ & $\mathrm{X}$ & $\bar{x}$ \\
\hline \multirow{2}{*}{ A02 } & $130 A 002$ & $2.5-3.0$ & Soil & Environmental & $x$ & $\bar{x}$ & $x$ & $x$ & $x$ & $x$ \\
\hline & $130 A 003$ & $2.5-3.0$ & Soil & FD of \#130A002 & $x$ & $x$ & $x$ & $x$ & $x$ & $x$ \\
\hline A03 & $130 A 004$ & $3.0-3.5$ & Soil & Environmental & $x$ & $\bar{x}$ & $x$ & $x$ & $x$ & $x$ \\
\hline$N / A$ & $130 \mathrm{~A} 301$ & $N / A$ & Water & Trip Blank & -- & -- & -- & -- & -- & $x$ \\
\hline$N / A$ & 130A302 & $N / A$ & Water & Trip Blank & -- & $\overline{--}$ & -- & -- & -- & $x$ \\
\hline $\mathrm{N} / \mathrm{A}$ & $130 \mathrm{~A} 303$ & N/A & Water & Field Blank & $x$ & $x$ & $x$ & $x$ & $x$ & $x$ \\
\hline
\end{tabular}

bgs $=$ Below ground surface

$\mathrm{DRO}=$ Diesel-range organics

FD = Field duplicate

$\mathrm{ft}=$ Foot

$--=$ Not required
$\mathrm{GRO}=$ Gasoline-range organics

N/A = Not applicable

SVOC $=$ Semivolatile organic compound

the stickup with native soils during the backfilling of the excavation. A complete discussion of investigative activities and analytical results is in Section D.3.0.

\subsubsection{CAS 07-02-01 Closure Activities}

The excavation revealed no USTs in CAS 07-02-01 but did reveal 5 concrete pads, 10 lead bricks, 8 Eveready dry cell batteries, and the determination that Station 7-235 is clean. Confirmation samples were collected to meet the requirements of the SAFER Plan (NNSA/NSO, 2008). The sample IDs, locations, types, and analyses are listed in Table 2-3. Potential source material (PSM) was present in the form of lead bricks. This PSM was removed under a corrective action of clean closure. The soil beneath the lead bricks was sampled, and the analytical results confirm that no COCs were identified. As a BMP, the lid to Station 7-235 was also tack-welded closed, and dry cell batteries within the CAS were collected and disposed. A complete discussion of investigative activities and analytical results is in Section D.4.0. 
Table 2-3

Samples Collected at CAS 07-02-01, Underground Storage Tanks

\begin{tabular}{|c|c|c|c|c|c|c|c|c|c|c|c|c|}
\hline $\begin{array}{l}\text { Sample } \\
\text { Location }\end{array}$ & $\begin{array}{l}\text { Sample } \\
\text { Number }\end{array}$ & $\begin{array}{l}\text { Depth } \\
\text { (ft bgs) }\end{array}$ & Matrix & Purpose & $\begin{array}{l}\text { 움 } \\
\text { 足 }\end{array}$ & 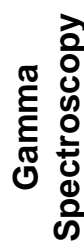 & 웅 & 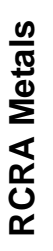 & 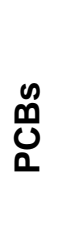 & 总 & $\begin{array}{l}\frac{n}{\pi} \\
\sum^{\frac{\pi}{0}} \\
0 \\
0 \\
0 \\
1\end{array}$ & $\begin{array}{l}\text { 仓̊ } \\
\text { O̊ }\end{array}$ \\
\hline B01 & 130B001 & $0.0-0.5$ & Soil & Environmental & $\mathrm{X}$ & $x$ & $\bar{x}$ & $x$ & $\bar{x}$ & $\mathrm{x}$ & -- & $\mathrm{X}$ \\
\hline \multirow[b]{2}{*}{ B02 } & 130B002 & $0.0-0.5$ & Soil & Environmental & $x$ & $x$ & $x$ & $x$ & $x$ & $x$ & $x$ & $x$ \\
\hline & 130B003 & $0.0-0.5$ & Soil & $\begin{array}{c}\text { FD of } \\
\# 130 B 002\end{array}$ & $\mathrm{x}$ & $\mathrm{x}$ & $x$ & $\mathrm{X}$ & $\mathrm{x}$ & $\mathrm{X}$ & -- & $\mathrm{x}$ \\
\hline B03 & 130B004 & $0.5-1.0$ & Soil & Environmental & $x$ & $x$ & $x$ & $x$ & $x$ & $x$ & -- & $x$ \\
\hline B04 & 130B005 & $3.0-3.5$ & Soil & Environmental & $x$ & $x$ & $x$ & $x$ & $x$ & $x$ & -- & $x$ \\
\hline N/A & 130B301 & $\mathrm{N} / \mathrm{A}$ & Water & Trip Blank & -- & -- & -- & -- & -- & -- & -- & $\mathrm{X}$ \\
\hline N/A & 130B302 & $\mathrm{N} / \mathrm{A}$ & Water & Trip Blank & -- & -- & -- & -- & -- & -- & -- & $x$ \\
\hline N/A & 130B303 & $\mathrm{N} / \mathrm{A}$ & Water & Field Blank & $x$ & $x$ & $x$ & $x$ & $x$ & $x$ & -- & $x$ \\
\hline N/A & 130B304 & $\mathrm{N} / \mathrm{A}$ & Water & Trip Blank & -- & -- & -- & -- & -- & -- & -- & $x$ \\
\hline N/A & 130B305 & $N / A$ & Water & Trip Blank & -- & -- & -- & -- & -- & -- & -- & $x$ \\
\hline
\end{tabular}

$\mathrm{PCB}=$ Polychlorinated biphenyl

TCLP $=$ Toxicity Characteristic Leaching Procedure

-- = Not required

\subsubsection{CAS 10-02-01 Closure Activities}

The excavation revealed no UST in CAS 10-02-01. The site had three pipes exposed approximately 12 inches (in.) above ground surface. The three pipes were connected to a concrete lid that covered a battery vault containing 118 dry cell batteries. Confirmation samples were collected to meet the requirements of the SAFER Plan (NNSA/NSO, 2008). The sample IDs, locations, types, and analyses are listed in Table 2-4. The analytical results confirm that no COCs were present. Best management practices were completed by removing the batteries and loose debris within the CAS for disposal, and backfilling the vault to grade with clean fill. A complete discussion of investigative activities and analytical results is in Section D.5.0. 
Table 2-4

Samples Collected at CAS 10-02-01, Underground Storage Tank

\begin{tabular}{|c|c|c|c|c|c|c|c|c|c|c|c|}
\hline $\begin{array}{l}\text { Sample } \\
\text { Location }\end{array}$ & $\begin{array}{l}\text { Sample } \\
\text { Number }\end{array}$ & $\begin{array}{c}\text { Depth } \\
\text { (ft bgs) }\end{array}$ & Matrix & Purpose & $\begin{array}{l}\text { 옴 } \\
\text { م⿱ 口}\end{array}$ & 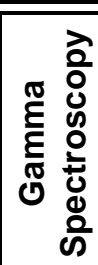 & 옹 & 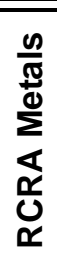 & 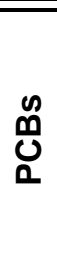 & 号 & $\begin{array}{l}\text { On } \\
\stackrel{\rho}{\prime}\end{array}$ \\
\hline$\overline{\mathrm{C} 01}$ & $130 \mathrm{C001}$ & $0.0-0.5$ & $\overline{\text { Soil }}$ & Environmental & $\bar{x}$ & $\bar{x}$ & $\bar{x}$ & $\bar{x}$ & $\bar{x}$ & $\bar{x}$ & $\bar{x}$ \\
\hline $\mathrm{CO2}$ & $130 \mathrm{C002}$ & $0.0-0.5$ & Soil & Environmental & $x$ & $x$ & $\bar{x}$ & $\bar{x}$ & $x$ & $x$ & $\bar{x}$ \\
\hline \multirow[b]{2}{*}{$\mathrm{CO3}$} & $130 \mathrm{C003}$ & $0.0-0.5$ & Soil & Environmental & $x$ & $x$ & $x$ & $x$ & $x$ & $x$ & $\mathrm{x}$ \\
\hline & $130 \mathrm{C} 004$ & $0.0-0.5$ & Soil & $\begin{array}{c}\text { FD of } \\
\# 130 \mathrm{C} 003\end{array}$ & $x$ & $x$ & $x$ & $x$ & $x$ & $x$ & $x$ \\
\hline $\mathrm{CO4}$ & $130 C 005$ & $0.0-0.5$ & Soil & Environmental & $\bar{x}$ & $x$ & $x$ & $\bar{x}$ & $x$ & $x$ & $\bar{x}$ \\
\hline $\mathrm{CO5}$ & $130 \mathrm{C} 006$ & $0.0-0.5$ & Soil & Environmental & $x$ & $x$ & $x$ & $x$ & $x$ & $x$ & $\mathrm{x}$ \\
\hline $\mathrm{CO6}$ & $130 C 007$ & $0.0-0.5$ & Soil & Environmental & $x$ & $x$ & $\bar{x}$ & $\bar{x}$ & $\bar{x}$ & $x$ & $\bar{x}$ \\
\hline $\mathrm{CO}$ & $130 C 008$ & $0.0-0.5$ & Soil & Environmental & $x$ & $x$ & $x$ & $x$ & $x$ & $x$ & $\bar{x}$ \\
\hline $\mathrm{C08}$ & $130 C 009$ & $6.5-7.0$ & Soil & Environmental & $\bar{x}$ & $x$ & $\bar{x}$ & $\bar{x}$ & $\bar{x}$ & $x$ & $\bar{x}$ \\
\hline C09 & $130 \mathrm{C} 010$ & $8.0-8.5$ & Soil & Environmental & $x$ & $x$ & $x$ & $x$ & $x$ & $x$ & $\bar{x}$ \\
\hline $\mathrm{N} / \mathrm{A}$ & $130 C 301$ & N/A & Water & Trip Blank & -- & -- & -- & -- & -- & -- & $\bar{x}$ \\
\hline $\mathrm{N} / \mathrm{A}$ & $130 C 302$ & N/A & Water & Trip Blank & -- & -- & -- & -- & - & -- & $\mathrm{x}$ \\
\hline $\mathrm{N} / \mathrm{A}$ & $130 \mathrm{C303}$ & N/A & Water & Trip Blank & -- & -- & -- & -- & -- & -- & $\bar{x}$ \\
\hline $\mathrm{N} / \mathrm{A}$ & $130 C 304$ & N/A & Water & Field Blank & $\bar{x}$ & $x$ & $x$ & $x$ & $x$ & $x$ & $\bar{x}$ \\
\hline
\end{tabular}

$--=$ Not required

\subsubsection{CAS 20-02-03 Closure Activities}

The excavation revealed no UST in CAS 20-02-03. The suspected location of the tank and the small anomaly were excavated. There was no tank identified, and the anomaly proved to be two t-posts. A confirmation sample was collected to meet the requirements of the SAFER Plan (NNSA/NSO, 2008). The sample IDs, locations, types, and analyses are listed in Table 2-5. The analytical results confirm that no COCs were identified. Best management practices were completed by removing and disposing the t-posts that were present at the CAS. A complete discussion of investigative activities and analytical results is in Section D.6.0. 
Table 2-5

Samples Collected at CAS 20-02-03, Underground Storage Tank

\begin{tabular}{|c|c|c|c|c|c|c|c|c|c|c|}
\hline $\begin{array}{l}\text { Sample } \\
\text { Location }\end{array}$ & $\begin{array}{l}\text { Sample } \\
\text { Number }\end{array}$ & $\begin{array}{c}\text { Depth } \\
\text { (ft bgs) }\end{array}$ & Matrix & Purpose & $\begin{array}{l}\text { 움 } \\
\text { 足 }\end{array}$ & 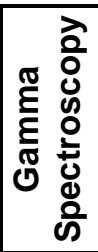 & $\begin{array}{l}\text { 웅 } \\
\text { 인 }\end{array}$ & 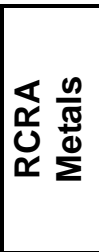 & 乫 & ơ \\
\hline \multirow{2}{*}{ D01 } & 130D001 & $2.0-2.5$ & 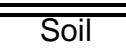 & 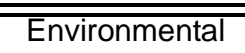 & $\overline{\bar{X}}$ & $\overline{\bar{X}}$ & $\overline{\bar{X}}$ & $\overline{\bar{x}}$ & $\bar{x}$ & $\bar{x}$ \\
\hline & 130D002 & $2.0-2.5$ & Soil & FD of \#130D001 & $\bar{X}$ & $\bar{x}$ & $\bar{X}$ & $\bar{x}$ & $\bar{x}$ & $\bar{X}$ \\
\hline $\mathrm{N} / \mathrm{A}$ & 130D301 & $\mathrm{N} / \mathrm{A}$ & Water & Trip Blank & $\overline{--}$ & $\overline{--}$ & $\overline{--}$ & $\overline{--}$ & -- & $\bar{x}$ \\
\hline N/A & 130D302 & $\mathrm{N} / \mathrm{A}$ & Water & Field Blank & $\mathrm{x}$ & $\bar{x}$ & $\mathrm{x}$ & $\bar{x}$ & $\mathrm{x}$ & $x$ \\
\hline
\end{tabular}

$--=$ Not required

\subsubsection{CAS 20-99-05 Closure Activities}

Samples were collected of the tar residue as PSM to meet the requirements of the SAFER Plan (NNSA/NSO, 2008). The sample IDs, locations, types, and analyses are listed in Table 2-6. The analytical results confirm that no COCs were present. Best management practices were completed by removing and disposing the tar residue and collecting confirmation environmental samples from below the material. The tar residue was collected and disposed of in the approved NTS waste facility. A complete discussion of investigative activities and analytical results is in Section D.7.0.

Table 2-6

Samples Collected at CAS 20-99-05, Tar Residue

\begin{tabular}{|c|c|c|c|c|c|c|c|c|c|c|c|c|c|c|c|c|c|}
\hline $\begin{array}{c}\text { Sample } \\
\text { Location }\end{array}$ & $\begin{array}{l}\text { Sample } \\
\text { Number }\end{array}$ & $\begin{array}{l}\text { Depth } \\
\text { (ft bgs) }\end{array}$ & Matrix & Purpose & $\begin{array}{l}\text { O } \\
\text { 足 }\end{array}$ & 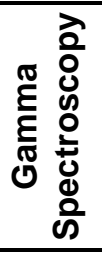 & 옹 & 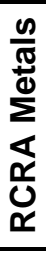 & 品 & 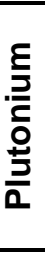 & $\frac{8}{\frac{1}{\omega}}$ & $\begin{array}{l}\text { ug } \\
\text { s }\end{array}$ & $\begin{array}{l}\frac{n}{\pi} \\
\frac{\pi}{2} \\
0 \\
\frac{1}{0} \\
\frac{0}{n}\end{array}$ & $\begin{array}{l}0 \\
\mathcal{O} \\
0 \\
0 \\
0 \\
0 \\
0\end{array}$ & 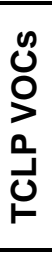 & 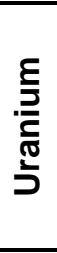 & $\begin{array}{l}\text { ủ } \\
\text { ơ }\end{array}$ \\
\hline E01 & 130E001 & $0.0-0.5$ & Soil & Environmental & $x$ & $\overline{--}$ & -- & $x$ & -- & -- & -- & $x$ & -- & 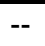 & -- & $\overline{--}$ & $x$ \\
\hline \multirow{2}{*}{ E02 } & 130E002 & $0.0-0.5$ & Soil & Environmental & $x$ & -- & -- & $x$ & -- & -- & -- & $x$ & -- & -- & -- & -- & $x$ \\
\hline & 130E003 & $0.0-0.5$ & Soil & FD of \#130E002 & $\mathrm{X}$ & -- & -- & $x$ & -- & -- & -- & $x$ & -- & -- & -- & -- & $x$ \\
\hline N/A & 130E301 & N/A & Water & Trip Blank & -- & -- & -- & -- & -- & -- & -- & -- & -- & -- & -- & -- & $x$ \\
\hline N/A & 130E302 & N/A & Water & Field Blank & $\mathrm{X}$ & -- & -- & $x$ & -- & -- & -- & $x$ & -- & -- & -- & -- & $x$ \\
\hline E01 & 130E501 & $\mathrm{N} / \mathrm{A}$ & Solid & $\begin{array}{c}\text { Waste } \\
\text { Management }\end{array}$ & $X$ & $\mathrm{X}$ & $X$ & -- & $x$ & $x$ & $x$ & -- & $X$ & $x$ & $x$ & $X$ & -- \\
\hline E02 & 130E502 & N/A & Solid & $\begin{array}{c}\text { Waste } \\
\text { Management }\end{array}$ & $X$ & $x$ & $X$ & -- & $x$ & $x$ & $x$ & -- & $x$ & $X$ & $x$ & $X$ & -- \\
\hline
\end{tabular}

$\mathrm{Sr}=$ Strontium

$--=$ Not required 


\subsubsection{CAS 22-02-02 Closure Activities}

The excavation confirmed the presence of buried distribution piping in CAS 22-02-02. Investigation included excavating and removing the buried distribution piping, and backfilling the foundation to grade. Confirmation samples were collected to meet the requirements of the SAFER Plan (NNSA/NSO, 2008). The sample IDs, locations, types, and analyses are listed in Table 2-7. The analytical results confirm that no COCs were present. Best management practices were completed by removing the buried distribution piping and associated lines, and disposing it as debris at the U10C Landfill as required. Loose debris within the CAS was also collected and disposed. A complete discussion of investigative activities and analytical results is in Section D.8.0.

Table 2-7

Samples Collected at CAS 22-02-02, Buried UST Piping

\begin{tabular}{|c|c|c|c|c|c|c|c|c|c|c|}
\hline $\begin{array}{l}\text { Sample } \\
\text { Location }\end{array}$ & $\begin{array}{l}\text { Sample } \\
\text { Number }\end{array}$ & $\begin{array}{c}\text { Depth } \\
\text { (ft bgs) }\end{array}$ & Matrix & Purpose & $\begin{array}{l}\text { 움 } \\
\text { 䒘 }\end{array}$ & 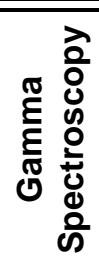 & $\begin{array}{l}\text { 운 } \\
\text { 인 }\end{array}$ & 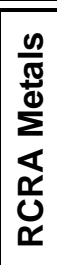 & $\overbrace{\text { on }}^{0}$ & $\begin{array}{l}\text { 仓ू } \\
\text { O }\end{array}$ \\
\hline$\overline{F 01}$ & 130F001 & $0.0-0.5$ & Soil & Environmental & $\bar{x}$ & $\bar{x}$ & $\bar{x}$ & $\bar{x}$ & $\bar{x}$ & $\bar{x}$ \\
\hline \multirow{2}{*}{ F02 } & 130F002 & $2.0-2.5$ & Soil & Environmental & $x$ & $x$ & $x$ & $x$ & $x$ & $x$ \\
\hline & 130F003 & $2.0-2.5$ & Soil & FD of $\# 130 F 002$ & $x$ & $x$ & $x$ & $x$ & $x$ & $x$ \\
\hline F03 & 130F004 & $2.5-3.0$ & Soil & Environmental & $x$ & $x$ & $x$ & $x$ & $x$ & $x$ \\
\hline $\mathrm{N} / \mathrm{A}$ & 130F301 & N/A & Water & Trip Blank & -- & -- & -- & -- & -- & $x$ \\
\hline $\mathrm{N} / \mathrm{A}$ & 130F302 & $\mathrm{N} / \mathrm{A}$ & Water & Trip Blank & -- & -- & -- & -- & -- & $x$ \\
\hline$N / A$ & 130F303 & N/A & Water & Trip Blank & -- & -- & -- & -- & -- & $\mathrm{x}$ \\
\hline N/A & 130F304 & N/A & Water & Field Blank & $x$ & $x$ & $x$ & $x$ & $x$ & $x$ \\
\hline $\mathrm{N} / \mathrm{A}$ & $130 \mathrm{~F} 305$ & $\mathrm{~N} / \mathrm{A}$ & Water & Source Material, QC & $x$ & $x$ & $x$ & $x$ & $x$ & $\bar{x}$ \\
\hline N/A & 130F306 & $N / A$ & Water & Equipment Rinsate & $x$ & $x$ & $x$ & $x$ & $x$ & $\mathrm{x}$ \\
\hline
\end{tabular}

-- = Not required 


\subsubsection{CAS 23-02-07 Closure Activities}

The excavation confirmed that the waste oil UST has been grouted and closed in place as historical documentation states at CAS 23-02-07. Confirmation samples were collected to confirm that there was no residual contamination and to meet the requirements of the SAFER Plan (NNSA/NSO, 2008). The sample IDs, locations, types, and analyses are listed in Table 2-8. The analytical results confirm that no COCs were identified. A complete discussion of investigative activities and analytical results is in Section D.9.0.

Table 2-8

Samples Collected at CAS 23-02-07, Underground Storage Tank

\begin{tabular}{|c|c|c|c|c|c|c|c|c|c|c|c|c|c|c|}
\hline $\begin{array}{l}\text { Sample } \\
\text { Location }\end{array}$ & $\begin{array}{l}\text { Sample } \\
\text { Number }\end{array}$ & $\begin{array}{c}\text { Depth } \\
\text { (ft bgs) }\end{array}$ & Matrix & Purpose & $\begin{array}{l}\text { 옴 } \\
\text { 茄 }\end{array}$ & 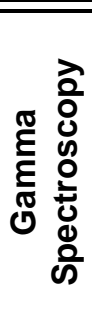 & 옹 & 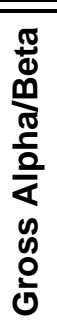 & 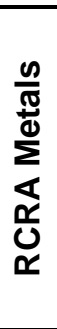 & 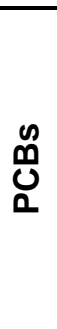 & $\begin{array}{l}\frac{d}{d} \\
\frac{0}{0} \\
\frac{0}{0} \\
0 \\
0\end{array}$ & 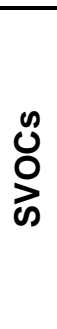 & 芷 & $\begin{array}{l}0 \\
\text { o } \\
\text { o }\end{array}$ \\
\hline G01 & 130G001 & $1.5-2.0$ & Soil & Environmental & $x$ & $\bar{x}$ & $\mathrm{X}$ & -- & $x$ & $\mathrm{x}$ & $x$ & $x$ & -- & $x$ \\
\hline \multirow{2}{*}{ G02 } & $130 \mathrm{G} 002$ & $7.5-8.0$ & Soil & Environmental & $x$ & $x$ & $x$ & -- & $x$ & $x$ & -- & $x$ & -- & $x$ \\
\hline & $130 \mathrm{G} 003$ & $7.5-8.0$ & Soil & FD of $\# 130 G 002$ & $x$ & $x$ & $x$ & -- & $x$ & $x$ & -- & $x$ & -- & $x$ \\
\hline G03 & 130G004 & $8.0-8.5$ & Soil & Environmental & $x$ & $x$ & $x$ & -- & $x$ & $x$ & -- & $x$ & -- & $x$ \\
\hline N/A & 130G301 & $\mathrm{N} / \mathrm{A}$ & Water & Trip Blank & -- & -- & -- & -- & -- & -- & -- & -- & -- & $x$ \\
\hline$N / A$ & 130G302 & $\mathrm{N} / \mathrm{A}$ & Water & Field Blank & $x$ & $x$ & $x$ & -- & $x$ & $x$ & -- & $x$ & -- & $x$ \\
\hline $\mathrm{N} / \mathrm{A}$ & $130 G 303$ & N/A & Water & Trip Blank & -- & -- & -- & -- & -- & -- & -- & -- & -- & $x$ \\
\hline N/A & 130G304 & N/A & Water & Trip Blank & -- & -- & -- & -- & -- & -- & -- & -- & -- & $x$ \\
\hline N/A & 130G305 & N/A & Water & Trip Blank & -- & -- & -- & -- & -- & -- & -- & -- & -- & $x$ \\
\hline $\begin{array}{l}\text { Drum \#130 } \\
\text { G01 }\end{array}$ & 130G501 & N/A & Liquid & $\begin{array}{c}\text { Waste } \\
\text { Management }\end{array}$ & $x$ & -- & $X$ & $x$ & $x$ & $x$ & -- & $x$ & $X$ & $x$ \\
\hline
\end{tabular}

$--=$ Not required 


\subsection{Deviations from SAFER Plan as Approved}

The CAU 130 initial sampling plan was based on the potential presence of USTs. Three of the CASs (01-02-01, 07-02-01, and 10-02-01) were determined to never have contained USTs. During the execution of the field investigation, the CSM and analytical suites were reviewed. It was determined that the CSM was still applicable to these three sites, and the analytical suites for each CAS was extensive enough to ensure that any releases of contamination would be identified.

There were four other minor deviations to the SAFER Plan requirements (NNSA/NSO, 2008). Corrective Action Site 07-02-01 had two minor additions to the sample strategy. Eight dry cell batteries were discovered during the investigation, and a confirmation soil sample was collected from beneath where they were removed. Second, eight additional lead bricks were discovered during the investigation, and a confirmation soil sample was collected from beneath where they were removed. Corrective Action Site 10-02-01 investigation revealed a vault with 118 dry cell batteries that were removed, packaged, and disposed. The fourth minor deviation comes from CAS 23-02-07. The addition of pesticides was added to sample 130G001 due to chlordane being detected in the PCB analysis.

\subsection{Corrective Action Schedule as Completed}

The CAU 130, Storage Tanks, investigation took place from August 4 through September 30, 2008. Table 2-9 presents a summary of these activities.

\subsection{Site Plans/Survey Plat}

The CAU 130 site investigation activities and surveys are presented in Figures D.3-1 through D.9-1. 
Table 2-9

Corrective Action Schedule for CAU 130

\begin{tabular}{|c|l|}
\hline Date & \\
\hline \hline August 4 to 6 & $\begin{array}{l}\text { Mobilization to CASs 20-02-03 and 20-99-05; site preparation, excavation, } \\
\text { and soil and tar sampling; sample shipping }\end{array}$ \\
\hline August 7 to 11 & $\begin{array}{l}\text { Mobilization to CAS 10-02-01; site preparation, excavation, and soil sampling; } \\
\text { sample shipping }\end{array}$ \\
\hline August 11 to 13 & $\begin{array}{l}\text { Mobilization to CAS 01-02-01; site preparation, excavation, and soil sampling; } \\
\text { sample shipping }\end{array}$ \\
\hline August 13 to 19 & $\begin{array}{l}\text { Mobilization to CAS 07-02-01; site preparation, excavation, and soil sampling; } \\
\text { sample shipping }\end{array}$ \\
\hline August 19 to 20 & $\begin{array}{l}\text { Mobilization to CAS 23-02-07; site preparation, excavation, and soil sampling; } \\
\text { sample shipping }\end{array}$ \\
\hline August 21 to 25 & $\begin{array}{l}\text { Mobilization to CAS 22-02-02; site preparation, excavation, and soil sampling; } \\
\text { sample shipping }\end{array}$ \\
\hline August 26 to 28 & $\begin{array}{l}\text { Mobilization to CAS 07-02-01; site preparation; excavation of all pads to } \\
\text { confirm not vaults; video recording inside Station 7-235 }\end{array}$ \\
\hline September 3 to 30 & $\begin{array}{l}\text { Mobilization to CAS 10-02-01; site preparation; lid removed from vault; } \\
\text { batteries removed and packaged for disposal; vault and surrounding area } \\
\text { backfilled to grade }\end{array}$ \\
\hline
\end{tabular}




\subsection{Waste Disposition}

Wastes generated during the SAFER Plan field activities included disposable personal protective equipment (PPE), disposable sampling equipment, piping and debris, dry cell batteries, liquid from an unmarked abandoned water line, housekeeping waste, and lead bricks. The lead bricks removed from CAS 07-02-01 were beneficially recycled and, therefore, not considered to be waste. The types, amounts, and disposal of the wastes are detailed in the following subsections. Newly generated wastes such as PPE/sampling debris (plastic/glass) have been characterized based on the associated soil samples and knowledge of the waste generating process. Waste containers not sampled directly were characterized based on process knowledge and analytical results of the corresponding soil samples. Site controls were in place to prevent the introduction of hazardous constituents to these waste streams.

\subsection{Waste Streams}

The waste generated by site closure activities at CAU 130 was segregated into the following waste streams:

- Industrial waste (i.e., PPE, disposable sampling equipment, plastic sheeting, glass/plastic sample jars, aluminum foil, and other debris such as concrete, asphalt, and piping)

- Liquids (from an abandoned water line in CAS 23-02-07)

- $\quad$ Batteries (dry cell)

- Tar residue

\subsection{Waste Sampling}

Waste determinations were made using process knowledge and media sample association.

Direct sampling was performed to confirm the regulatory status of PSM at CAS 07-02-01 and investigation-derived waste (IDW) at CASs 20-99-05 and 23-02-07.

Two samples were collected for waste stream determination of the tar residue at CAS 20-99-05. The samples were analyzed for TCLP VOCs, TCLP SVOCs, TCLP metals, total petroleum hydrocarbons 
(TPH)-GRO, TPH-DRO, PCBs, gamma spectroscopy, isotopic uranium (U), isotopic plutonium (Pu), and Sr-90.

One composite sample was collected for waste stream determination of the liquid at CAS 23-02-07. The sample was analyzed for VOCs, SVOCs, RCRA metals, TPH-GRO, TPH-DRO, PCBs, gross alpha, gross beta, and tritium.

\subsection{Waste Disposal}

Wastes generated during this CAI were approximately 16 cubic yards $\left(\mathrm{yd}^{3}\right)$ of demolition debris, 1 standard size bag of PPE, 126 batteries, one-half 55-gallon (gal) drum of tar residue, 10 lead bricks, two 55-gal drums and one 10-gal drum of liquid, and general office wastes. These wastes were managed as follows:

- All PPE and disposable sampling equipment generated during site closure activities were determined to be sanitary based on visual inspection, radiological field screening, and process knowledge. The waste was bagged, labeled, and placed in the designated sanitary industrial waste containers located at Building 23-153 and allocated for disposal at the Area 9 U10c Industrial Waste Landfill.

- Demolition debris (piping, concrete, asphalt, steel, batteries) generated during site closure activities was determined to be sanitary based on process knowledge and visual inspection. The waste was disposed of at the Area 9 U10c Industrial Waste Landfill.

- The tar residue was characterized based on direct sample data as hydrocarbon waste exceeding the regulatory threshold, established by the State of Nevada regulations (NDEP, 1997a and b). The tar residue was disposed at the permitted Area 6 Hydrocarbon Landfill.

- The liquid from CAS 23-02-07 was characterized based on direct sample data and disposed of at the NTS Area 23 Lagoon. 


\subsection{Closure Verification Results}

Closure verification results consist of the analytical results from environmental samples that demonstrate that closure objectives were met. For NFA, verification results demonstrate that COCs do not exist within the CASs.

The CAU 130 SAFER Plan (NNSA/NSO, 2008) identified the right type, quality, and quantity of data needed to resolve the DQO decision statements. To verify that the dataset obtained as a result of this CAI supports the DQO decisions, a DQA was conducted. Section 4.1 provides a summary of the DQA, and Section 4.2 summarizes any URs for each CAS.

This section provides a summary of verification data from the closure activities as detailed in Appendix D. Except as noted in the following CAS-specific sections, CAU 130 sampling locations were accessible, and sampling activities at planned locations were not restricted by buildings, storage areas, active operations, or aboveground and underground utilities. The following subsections provide a summary of the CAS-specific verification results as presented in Appendix D.

No COCs were identified at CASs 01-02-01, 10-02-01, 20-02-03, 20-99-05, and 22-02-02. The analytical data support NFA for these CASs.

Although no COCs were identified at CAS 07-02-01, PSM in the form of lead bricks was present. These lead bricks were removed as a corrective action of clean closure and beneficially recycled within the DOE Complex recycling program. Verification soil samples were collected from below the lead bricks and analyzed. The analytical data verify the successful completion of clean closure.

Total petroleum hydrocarbons-DRO were detected above the preliminary action level (PAL) in one soil sample collected from CAS 23-02-07. The Tier 2 evaluation determined that no hazardous constituents of diesel were detected above PALs; therefore, TPH-DRO is not a COC. No COCs were identified at this CAS. The analytical data support NFA alternative for this CAS. 


\subsection{Data Quality Assessment}

The DQA process is the scientific statistical evaluation of the actual CAI results to determine whether the DQO criteria established in the CAU 130 SAFER Plan (NNSA/NSO, 2008) were met and whether DQO decisions can be resolved at the desired level of confidence. The DQO process ensures that the right type, quality, and quantity of data will be available to support the resolution of those decisions at an appropriate level of confidence. Application of both the DQO and DQA processes helps to ensure that DQO decisions are sound and defensible.

The DQA involves five steps that begin with a review of the DQOs and end with an answer to the DQO decisions. The five steps are briefly summarized as follows:

Step 1: Review DQOs and Sampling Design - Review the DQO process to provide context for analyzing the data. State the primary statistical hypotheses; confirm the limits on decision errors for committing false negative (Type I) or false positive (Type II) decision errors; and review any special features, potential problems, or any deviations to the sampling design.

Step 2: Conduct a Preliminary Data Review - A preliminary data review should be performed by reviewing quality assurance (QA) reports and inspecting the data both numerically and graphically, validating and verifying the data to ensure that the measurement systems performed are within the specified criteria, and using the validated dataset to determine whether the quality of the data is satisfactory.

Step 3: Select the Test - Select the test based on the population of interest, population parameter, and hypotheses. Identify the key underlying assumptions that could cause a change in one of the DQO decisions.

Step 4: Verify the Assumptions - Perform tests of assumptions. If data are missing or censored, determine the impact on DQO decision error.

Step 5: Draw Conclusions from the Data - Perform the calculations required for the test. 


\subsubsection{Review DQOs and Sampling Design}

This section contains a review of the DQO process presented in Appendix A. The DQO decisions are presented with the DQO provisions to limit false negative or false positive decision errors. Special features, potential problems, or any deviations to the sampling design are also presented.

\subsubsection{Decision I}

The Decision I statement as presented in the CAU 130 SAFER Plan is: "Is any COC present in environmental media within the CAS?”

Decision I Rules:

- If the population parameter of any contaminant of potential concern (COPC) in a target population exceeds the FAL for that COPC, then that COPC is identified as a COC.

- If a COC is detected, then the Decision II statement must be resolved.

- If COCs are not identified, then the investigation is complete.

Population Parameter: For judgmental sampling results, the population parameter is the maximum observed sample result from each individual sample.

\subsubsection{DQO Provisions To Limit False Negative Decision Error}

A false negative decision error (where consequences are more severe) was controlled by meeting the following criteria:

1. Having a high degree of confidence that the locations selected will identify COCs if present anywhere within the CAS.

2. Having a high degree of confidence that the analyses conducted will be sufficient to detect any COCs present in the samples.

3. Having a high degree of confidence that the dataset is of sufficient quality and completeness. 


\section{Criterion 1:}

The following methods (detailed in the CAU 130 DQOs [NNSA/NSO, 2008]) were used in selecting sample locations that have the highest potential for detecting a release, if present:

1. Selection of sampling locations associated with a release of effluent to the surrounding soils from pipe tie-in locations or pipe joints based on visual observations.

2. Selection of sampling locations associated with surface and subsurface staining, odors, presence of debris, etc.

3. Selection of sampling locations using professional judgment and based on available information was influenced by:

- Source and location of release

- Chemical nature and fate properties

- Physical transport pathways and properties

- Transport drivers

\section{Criterion 2:}

All samples were analyzed using the analytical methods listed in Table 3-2 of the SAFER Plan and for the radiological and chemical parameters listed in Tables 3-4 and 3-5, respectively, of the SAFER Plan (NNSA/NSO, 2008). Table 4-1 provides a reconciliation of samples analyzed to the planned analytical program.

Sample results were assessed against the acceptance criterion for the DQI of sensitivity as defined in the Industrial Sites QAPP (NNSA/NV, 2002). The sensitivity acceptance criterion defined in the SAFER Plan is that analytical detection limits will be less than the corresponding action level. This criterion was not achieved for the CAS 23-02-07 analytical results listed in Table 4-2. The results that did not meet the sensitivity acceptance criterion were not used in making DQO decisions and are therefore considered to be rejected data. The impact on DQO decisions is addressed in the assessment of completeness.

\section{Criterion 3:}

To satisfy the third criterion, the entire dataset, as well as individual sample results, were assessed against the acceptance criteria for the DQIs of precision, accuracy, representativeness, completeness, 
Table 4-1

CAU 130 Analyses Performed

\begin{tabular}{|c|c|c|c|c|c|c|c|c|c|c|c|c|c|c|c|}
\hline \multirow[b]{2}{*}{ CAS } & \multicolumn{15}{|c|}{ ANALYTES } \\
\hline & 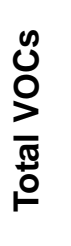 & 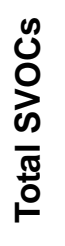 & $\begin{array}{l}\mathscr{n} \\
\text { Oñ }\end{array}$ & $\begin{array}{l}\frac{n}{\mathbb{T}} \\
\frac{\mathbb{U}}{\Sigma}\end{array}$ & 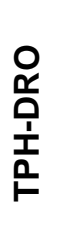 & $\begin{array}{l}0 \\
\text { O } \\
0 \\
\frac{1}{1} \\
\frac{1}{1}\end{array}$ & $\begin{array}{l}0 \\
\frac{0}{0} \\
י \frac{0}{0} \\
\frac{0}{0} \\
0 \\
0\end{array}$ & 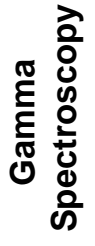 & 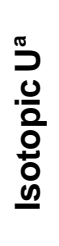 & 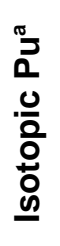 & $\begin{array}{l}\stackrel{0}{8} \\
\frac{1}{5} \\
\bar{n}\end{array}$ & 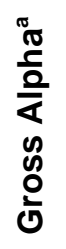 & 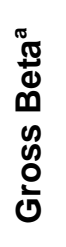 & 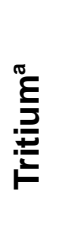 & 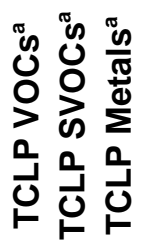 \\
\hline $01-02-01$ & RS & RS & -- & RS & RS & $\overline{R S}$ & -- & $\mathrm{RS}$ & -- & -- & -- & -- & $\overline{--}$ & -- & -- \\
\hline $07-02-01$ & RS & $\mathrm{RS}$ & $\mathrm{RS}$ & RS & $\mathrm{RS}$ & RS & -- & RS & -- & -- & -- & -- & -- & -- & $\mathrm{S}$ \\
\hline $10-02-01$ & $\mathrm{RS}$ & $\mathrm{RS}$ & $\mathrm{RS}$ & $\mathrm{RS}$ & $\mathrm{RS}$ & $\mathrm{RS}$ & -- & $\mathrm{RS}$ & -- & -- & -- & -- & -- & -- & -- \\
\hline $20-02-03$ & $\mathrm{RS}$ & $\mathrm{RS}$ & -- & $\mathrm{RS}$ & RS & RS & -- & RS & -- & -- & -- & -- & -- & -- & -- \\
\hline $20-99-05$ & $\mathrm{RS}$ & $\mathrm{RS}$ & $\mathrm{RS}$ & $\mathrm{RS}$ & RS & $\mathrm{RS}$ & -- & RS & $\mathrm{RS}$ & RS & $\mathrm{RS}$ & -- & -- & -- & $\mathrm{RS}$ \\
\hline $22-02-02$ & $\mathrm{RS}$ & $\mathrm{RS}$ & -- & $\mathrm{RS}$ & $\mathrm{RS}$ & $\mathrm{RS}$ & -- & $\mathrm{RS}$ & -- & -- & -- & -- & -- & -- & -- \\
\hline $23-02-07$ & RS & RS & RS & RS & RS & RS & $\mathrm{S}$ & RS & -- & -- & -- & RS & RS & RS & -- \\
\hline
\end{tabular}

${ }^{a}$ Waste management analyses only

$\mathrm{RS}=$ Required and submitted

$\mathrm{S}=$ Not required but submitted

-- = Not applicable 
Table 4-2

Analytes Failing Sensitivity Criteria for CAU 130

\begin{tabular}{|c|c|c|c|c|}
\hline \multirow{2}{*}{ CAS } & $\begin{array}{c}\text { Sample } \\
\text { Number }\end{array}$ & Contaminant & $\begin{array}{c}\text { MDC } \\
(\mathbf{m g} / \mathbf{k g})\end{array}$ & $\begin{array}{c}\text { FAL } \\
(\mathbf{m g} / \mathbf{k g})\end{array}$ \\
\hline \hline \multirow{2}{*}{$23-02-07$} & 130 G001RR1 & Benzo(a)pyrene & 1 & 0.21 \\
\cline { 2 - 5 } & 130 G001RR1 & Dibenzo(a,h)anthracene & 1 & 0.21 \\
\hline
\end{tabular}

MDC = Minimum detectable concentration

$\mathrm{mg} / \mathrm{kg}=$ Milligrams per kilogram

and comparability, as defined in the Industrial Sites QAPP (NNSA/NV, 2002). The DQI acceptance criteria are presented in Table 7-1 of the SAFER Plan (NNSA/NSO, 2008). As presented in Tables 4-2 through 4-4, these criteria were met for each of the DQIs.

\section{$\underline{\text { Precision }}$}

Precision is evaluated using the relative percent difference (RPD), normalized difference and/or absolute difference as appropriate.

Table 4-3 provides the chemical and radiological precision analysis results for the analyte lead that was qualified for precision. No other radionuclides or chemicals were qualified for precision.

Table 4-3

Precision Measurements

\begin{tabular}{|c|c|c|c|}
\hline Analyte & $\begin{array}{c}\text { Number of } \\
\text { Measurements } \\
\text { Qualified }\end{array}$ & $\begin{array}{c}\text { Number of } \\
\text { Measurements } \\
\text { Performed }\end{array}$ & $\begin{array}{c}\text { Percent } \\
\text { within } \\
\text { Criteria }\end{array}$ \\
\hline \hline Lead & 7 & 32 & 78.1 \\
\hline
\end{tabular}

As shown in Table 4-3, the precision rate for lead did not meet the SAFER Plan acceptance criterion of 80 percent. The precision rate for lead of 78.1 percent can be attributed to the nature of lead distribution. High variability in the sampled matrix may indicate the potential for a false negative or positive decision error if the analyzed portion of the sample was not representative of the total sample. However, there is negligible potential for a false negative DQO decision error because the highest reported values are still minimal in comparison to the FAL. The FAL for lead is $800 \mathrm{mg} / \mathrm{kg}$, which is significantly higher than the highest reported lead concentration of $430 \mathrm{mg} / \mathrm{kg}$. Therefore, the dataset is determined to be acceptable for the DQI of precision. 


\section{Accuracy}

For the purpose of determining data accuracy of sample analyses, environmental soil samples were evaluated and incorporated into the accuracy calculation. The results qualified for accuracy were associated with matrix spike (MS) recoveries that were outside control limits and could potentially be reported at concentrations lower or higher than actual concentrations. Table 4-4 provides the chemical accuracy analysis results for all analytes qualified for accuracy. Accuracy rates are above the SAFER Plan criterion of 80 percent, except for mercury, which has a rate of 78.1 percent. There was no radiological data qualified for accuracy.

Table 4-4

Accuracy Measurements

\begin{tabular}{|c|c|c|c|}
\hline Analyte & $\begin{array}{c}\text { Number of } \\
\text { Measurements Qualified }\end{array}$ & $\begin{array}{c}\text { Number of } \\
\text { Measurements Performed }\end{array}$ & $\begin{array}{c}\text { Percent within } \\
\text { Criteria }\end{array}$ \\
\hline \hline Benzene & 1 & 32 & 96.9 \\
\hline Toluene & 2 & 32 & 93.8 \\
\hline Trichloroethene & 2 & 32 & 93.8 \\
\hline Chlorobenzene & 4 & 32 & 87.5 \\
\hline Mercury & 7 & 32 & 78.1 \\
\hline
\end{tabular}

Of the 32 mercury results qualified for accuracy, 7 were associated with an MS recovery that exceeded the upper limits. This would indicate that the associated samples may have been reported with concentrations higher than the actual concentration. This inaccuracy could impact a DQO decision by causing a false positive decision error. However, this did not occur at CAU 130 because no mercury results exceeded the FAL of $310 \mathrm{mg} / \mathrm{kg}$, which is significantly higher than the highest reported mercury concentration of $0.031 \mathrm{mg} / \mathrm{kg}$. Therefore, the mercury results that were qualified for reasons of accuracy can be confidently used to support DQO decisions. As the accuracy rate for all other analytes meet the acceptance criteria for accuracy, the dataset is determined to be acceptable for the DQI of accuracy.

\section{Representativeness}

The DQO process as identified in Appendix A was used to address sampling and analytical requirements for CAU 130. During this process, appropriate locations were selected that enabled the samples collected to be representative of the population parameter identified in the DQO (the most 
likely locations to contain contamination and locations that bound COCs). The sampling locations identified in the Criterion 1 discussion met this criterion. Therefore, the analytical data acquired during the CAU $130 \mathrm{CAI}$ are considered representative of the population parameter.

\section{Completeness}

The CAU 130 SAFER Plan (NNSA/NSO, 2008) defines acceptable criteria for completeness to be 80 percent of CAS-specific non-target analytes identified in the SAFER Plan having valid results and 100 percent of target contaminants having valid results (including Decision II samples). Also, the dataset must be sufficiently complete to be able to make the DQO decisions. Target analytes for the CAU 130 CASs are identified as VOCs, SVOCs, and the hazardous constituents of diesel for CASs 01-02-01, 20-99-05, 22-02-02, and 23-02-07; lead associated with lead bricks at CAS 07-02-01; and lead associated with leaded gasoline at CAS 22-02-02. There were no data qualified as rejected for CAU 130. However, Table 4-2 lists samples from CAS 23-02-07 that were rejected for failing sensitivity.

Benzo(a)pyrene and dibenzo(a,h)anthracene did not meet the criteria for sensitivity and are, therefore, considered rejected data that did not meet the 100 percent completeness criterion for targeted contaminants. The data that failed sensitivity were not used in the resolution of DQO decisions.

The benzo(a)pyrene and dibenzo(a,h)anthracene failed sensitivity in one sample from CAS 23-02-07 (130G001) because it was diluted during preparation due to matrix interferences, which resulted in elevated detection limits that were greater than their corresponding FAL concentrations. However, valid results were obtained for these two contaminants in three other samples from this CAS in which these contaminants were not detected. Therefore, there is no suspicion that these contaminants are present at CAS 23-02-07, and there is sufficient information to support the DQO decisions at this CAS. Therefore, the dataset was determined to be acceptable for completeness.

\section{Comparability}

Field sampling, as described in the CAU 130 SAFER Plan (NNSA/NSO, 2008), was performed and documented in accordance with approved procedures that are in conformance with standard industry practices. Analytical methods and procedures approved by DOE, National Nuclear Security Administration Nevada Site Office (NNSA/NSO) were used to analyze, report, and validate the data. 
These methods and procedures are in conformance with applicable methods used in industry and government practices. Therefore, project datasets are considered comparable to other datasets generated using standard industry procedures, thereby meeting DQO requirements.

\subsubsection{DQO Provisions To Limit False Positive Decision Error}

The false positive decision error was controlled by assessing the potential for false positive analytical results. Quality control samples with established control criteria were used in the evaluation of false positive analytical results during the Tier II validation process. Sample results impacted from false positive control criteria were accounted for and qualified accordingly per approved Stoller-Navarro Joint Venture (SNJV) procedures. Proper decontamination of sampling equipment and the use of certified clean sampling equipment and containers also minimized the potential for cross contamination that could lead to a false positive analytical result.

Seven field blanks, one equipment rinse, and one FD soil sample collected for CAU 130 contained trace amounts of acetone. The detectable amount of acetone is below the PAL. Because the detection is below the PAL and this was not identified as a potential contaminant during the DQO process, the dataset meets the criteria that sufficient information was collected to determine that no false positive analytical results were detected.

\subsubsection{Decision II}

The Decision II statement as presented in the CAU 130 SAFER Plan is: "If a COC is present, is sufficient information available to meet closure objectives?”

\section{Decision Rules:}

- If the observed concentration of any COC in a Decision II sample exceeds the PALs, then additional samples will be collected to complete the determination of the extent.

- If observed COC concentrations in a sample from all bounding directions are less than the PALs, then the decision will be that the extent of contamination has been defined in the lateral and/or vertical direction.

- If wastes are to be generated as part of a corrective action, samples will be collected to sufficiently characterize the potential wastes. 
No COCs were determined to be present at any CAU 130 CAS. No extent sampling was required. Also, as there were no corrective action wastes generated, no waste samples were collected.

\subsubsection{Sampling Design}

The SAFER Plan made the following commitments for sampling:

- Biased locations will have soil samples collected beneath and/or adjacent to USTs and associated piping, UST piping, tar residue, and concrete pads to identify releases of potential contaminants.

Result: All UST and piping system components at each CAS were investigated by excavation and soil samples were collected adjacent to and from beneath the required components such as the base of UST, associated piping, concrete pads, and buried UST piping.

\subsubsection{Conduct a Preliminary Data Review}

A preliminary data review was conducted by reviewing QA reports and inspecting the data. The contract analytical laboratories generate a QA nonconformance report when data quality does not meet contractual requirements. A data review was conducted by evaluating laboratory analytical data and laboratory issued nonconformance reports. When applicable, the nonconformances were used to qualify the analytical data as appropriate. When quality-affecting issues were not identified by the laboratory, the data reviewer contacted the laboratory upon observance and a corrective action was implemented immediately, including qualification of the data as appropriate and issuance of laboratory nonconformance reports. The validated dataset quality was found to be satisfactory.

\subsubsection{Select the Test and Identify Key Assumptions}

The test for making DQO Decision I for the judgmental sampling design was the comparison of the maximum analyte result from each CAS to the corresponding FAL. The test for making DQO Decision II was the comparison of all COC analyte results from each bounding sample to the corresponding FALs.

The key assumptions that could impact a DQO decision are listed in Table 4-5. 


\section{Key Assumptions}

\begin{tabular}{|c|c|}
\hline Exposure Scenario & $\begin{array}{l}\text { Site workers are only exposed to COCs through oral ingestion, inhalation, external } \\
\text { exposure to radiation, or dermal contact (by absorption) of COCs absorbed onto } \\
\text { the soils. } \\
\text { Exposure to contamination is limited to site workers, construction/remediation } \\
\text { workers, and military personnel conducting training. } \\
\text { The investigation results did not reveal any potential exposures other than those } \\
\text { identified in the CSM. }\end{array}$ \\
\hline Affected Media & $\begin{array}{l}\text { Surface soil, shallow subsurface soil, and potentially perched (shallow) groundwater. } \\
\text { Deep groundwater contamination is not a concern. } \\
\text { Contaminants migrating to regional aquifers are not considered. } \\
\text { The investigation results did not reveal any affected media other than those identified } \\
\text { in the CSM. }\end{array}$ \\
\hline $\begin{array}{l}\text { Location of } \\
\text { Contamination/Release Points }\end{array}$ & $\begin{array}{l}\text { Release points are those identified in the SAFER Plan } \\
\text { The investigation results did not reveal any locations of contamination or release } \\
\text { points other than those identified in the SAFER Plan. }\end{array}$ \\
\hline Transport Mechanisms & $\begin{array}{l}\text { Surface transport may occur as a result of a spill or stormwater runoff. } \\
\text { Surface transport beyond shallow substrate is not a concern. } \\
\text { The investigation results did not reveal any transport mechanisms other than those } \\
\text { identified in the CSM. }\end{array}$ \\
\hline Preferential Pathways & $\begin{array}{l}\text { None. } \\
\text { The investigation results did not reveal any preferential pathways }\end{array}$ \\
\hline $\begin{array}{l}\text { Lateral and Vertical Extent of } \\
\text { Contamination }\end{array}$ & $\begin{array}{l}\text { None. } \\
\text { The investigation results did not reveal any lateral or vertical extent of contamination. }\end{array}$ \\
\hline Groundwater impacts & $\begin{array}{l}\text { None. } \\
\text { The investigation results did not reveal any indicators that groundwater could be } \\
\text { potentially impacted }\end{array}$ \\
\hline Future Land Use & $\begin{array}{l}\text { Nonresidential. } \\
\text { The investigation results did not reveal any future land uses other than nonresidential. }\end{array}$ \\
\hline
\end{tabular}




\subsubsection{Verify the Assumptions}

The results of the investigation support the key assumptions of potential USTs, bunkers, tar residue, and buried UST piping identified in the CAU 130 DQOs and Table 4-5. All data collected during the CAI supported the CSM.

\subsubsection{Other DQO Commitments}

The SAFER Plan made the following commitments for sampling:

- Decision II sampling will consist of defining the extent of contamination where COCs have been confirmed at the Decision I locations. If COCs extend beyond Decision II locations, then additional Decision II samples will be collected from a location in the direction outward and in the inferred downgradient direction. The Decision II locations will be positioned at an adequate distance from the stepout locations and be advanced to provide samples in order to profile COC concentrations through the upper and lower boundaries of detectable contamination. A clean sample (i.e., results less than FALs) will define the vertical and lateral extent of contamination at the respective locations. The contamination boundaries may need to be extrapolated to give an overall view of the lateral and vertical extent of contamination at the site.

Result: Not applicable because no COCs were identified at any CAU 130 CAS.

\subsubsection{Draw Conclusions from the Data}

This section resolves the two DQO decisions for each of the CAU 130 CASs.

\subsubsection{Decision Rules for Decision I}

Decision Rule: If the concentration of any COPC in a target population exceeds the FAL for that COPC during the initial investigation, then that COPC is identified as a COC and Decision II sampling will be conducted.

Result: Lead bricks as PSM were discovered at CAS 07-02-01 and removed. No COCs remain at CAS 07-02-01. No COCs were identified at any of the other CAU 130 CASs

Decision Rule: If all COPC concentrations are less than the corresponding FALs, then the decision will be NFA. 
Result: As no COCs were identified and the PSM removed, no further corrective actions are required to close the CAU 130 CASs.

\subsubsection{Decision Rules for Decision II}

Decision Rule: If the observed concentration of any COC in a Decision II sample exceeds the FALs, then additional samples will be collected to complete the determination of the extent.

Result: No COCs were identified during the Decision I activities; therefore, bounding samples were not necessary or collected.

Decision Rule: If all observed COC population parameters are less than the FALs, then the decision will be that the extent of contamination has been defined in the lateral and/or vertical direction.

Result: No COCs were identified during the Decision I activities; therefore, bounding samples were not necessary or collected.

\subsection{Use Restrictions}

Analytes detected in soil during the CAI activities at CAU 130 were evaluated against FALs, and it was determined that no COCs were present. Therefore, no URs are necessary at this CAU. 


\subsection{Conclusions and Recommendations}

Based on the results of the closure activities, no further corrective actions are necessary for the CASs within CAU 130.

The NNSA/NSO provides the following recommendations:

- Except for CAS 07-02-07, no further corrective action is required at any CAU 130 CAS.

- Lead bricks (i.e., PSM) were identified within the boundary of CAS 07-02-01. As part of the clean closure, these bricks were removed from the CAS and disposed of properly. Based on the removal of PSM and analytical results of the environmental samples, no further corrective action is required.

- $\quad$ No Corrective Action Plan is required for CAU 130.

- A Notice of Completion is requested from NDEP for the closure of CAU 130.

- Corrective Action Unit 130 should be moved from Appendix III to Appendix IV of the FFACO, signifying closure. 


\subsection{References}

EPA, see U.S. Environmental Protection Agency.

FFACO, see Federal Facility Agreement and Consent Order.

Federal Facility Agreement and Consent Order. 1996 (as amended February 2008). Agreed to by the State of Nevada; U.S. Department of Energy, Environmental Management; U.S. Department of Defense; and U.S. Department of Energy, Legacy Management.

NDEP, see Nevada Division of Environmental Protection.

NNSA/NSO, see U.S. Department of Energy, National Nuclear Security Administration Nevada Site Office.

NNSA/NV, see U.S. Department of Energy, National Nuclear Security Administration Nevada Operations Office.

Nevada Division of Environmental Protection. 1997a. Class II Solid Waste Disposal Site for Municipal and Industrial Solid Waste, Area 23 of the NTS, Permit SW 1309704. Carson City, NV.

Nevada Division of Environmental Protection. 1997b (as amended in August 2000). Class III Solid Waste Disposal Site for Hydrocarbon Burdened Soils, Area 6 of the NTS, Permit SW 1309702. Carson City, NV.

SNJV GIS Systems, see Stoller-Navarro Joint Venture Geographic Information Systems.

Stoller-Navarro Joint Venture Geographic Information Systems. 2009. ESRI ArcGIS Software.

U.S. Department of Energy, National Nuclear Security Administration Nevada Operations Office. 2002. Industrial Sites Quality Assurance Project Plan, Nevada Test Site, Nevada, Rev. 3, DOE/NV--372. Las Vegas, NV.

U.S. Department of Energy, National Nuclear Security Administration Nevada Site Office. 2008. Streamlined Approach for Environmental Restoration (SAFER) for Corrective Action Unit 130: Storage Tanks, Nevada Test Site, Nevada, Rev. 0, DOE/NV--1276. Las Vegas, NV.

U.S. Environmental Protection Agency. 2006. Guidance for the Data Quality Objectives Process, EPA QA/G-4. Washington, DC. 


\section{Appendix A}

\section{Data Quality Objectives as Developed in the SAFER Plan}

Note: This appendix contains the DQOs presented in SAFER Plan and consists of Appendix B of the SAFER Plan. Therefore, all cross-references, page numbers, and header information in this appendix refer to the original document. 


\section{A.1.0 Introduction}

The DQO process described in this appendix is a seven-step strategic systematic planning method used to plan data collection activities and define performance criteria for the CAU 130, Storage Tanks, field investigation. The DQOs are designed to ensure that the data collected will provide sufficient and reliable information to determine the appropriate corrective actions, verify the adequacy of existing information, provide sufficient data to implement the corrective actions, and verify that closure was achieved.

The CAU 130 investigation will be based on the DQOs presented in this appendix as developed by representatives of the NDEP and NNSA/NSO. The seven steps of the DQO process presented in Sections A.2.0 through A.8.0 were developed in accordance with EPA Guidance on Systematic Planning Using the Data Quality Objectives Process (EPA, 2006) and the CAS-specific information presented in Section A.2.0.

The DQO process for CAU 130 presents a judgmental sampling approach. In general, the procedures used in the DQO process provide:

- A method to establish performance or acceptance criteria, which serve as the basis for designing a plan for collecting data of sufficient quality and quantity to support the goals of a study.

- Criteria that will be used to establish the final data collection design such as:

- The nature of the problem that has initiated the study and a conceptual model of the environmental hazard to be investigated

- The decisions or estimates that need to be made and the order of priority for resolving them

- The type of data needed

- An analytic approach or decision rule that defines the logic for how the data will be used to draw conclusions from the study findings

- Acceptable quantitative criteria on the quality and quantity of the data to be collected, relative to the ultimate use of the data. 
- A data collection design that will generate data meeting the quantitative and qualitative criteria specified. A data collection design specifies the type, number, location, and physical quantity of samples and data, as well as the QA and QC activities that will ensure that sampling design and measurement errors are managed sufficiently to meet the performance or acceptance criteria specified in the DQOs. 


\section{A.2.0 Step 1 - State the Problem}

Step 1 of the DQO process defines the problem that requires study, identifies the planning team, and develops a conceptual model of the environmental hazard to be investigated.

The problem statement for the CAU 130 CASs is: "Existing information on the nature and extent of potential contamination is insufficient to evaluate and confirm closure of the individual CASs in CAU 130.”

\section{A.2.1 Planning Team Members}

The DQO planning team consists of representatives from NDEP, NNSA/NSO, Stoller-Navarro Joint Venture (SNJV), and National Security Technologies, LLC (NSTec). The DQO planning team met on April 3, 2008, for the DQO meeting. The primary decision-makers are NDEP and NNSA/NSO representatives.

\section{A.2.2 Conceptual Site Model}

The CSM is used to organize and communicate information about site characteristics. It reflects the best interpretation of available information at any point in time. The CSM is a primary vehicle for communicating assumptions about release mechanisms, potential migration pathways, or specific constraints. It provides a summary of how and where contaminants are expected to move and what impacts such movement may have. It is the basis for assessing how contaminants could reach receptors both in the present and future. The CSM describes the most probable scenario for current conditions at each site and defines the assumptions that are the basis for identifying appropriate sampling strategy and data collection methods. Accurate CSMs are important as they serve as the basis for all subsequent inputs and decisions throughout the DQO process.

The CSM was developed for CAU 130 using information from the physical setting, potential contaminant sources, release information, historical background information, knowledge from similar sites, and physical and chemical properties of the potentially affected media and COPCs. 
The CSM consists of:

- Potential contaminant releases including media subsequently affected.

- Release mechanisms (the conditions associated with the release).

- Potential contaminant source characteristics, including contaminants suspected to be present and contaminant-specific properties.

- Site characteristics including physical, topographical, and meteorological information.

- Migration pathways and transport mechanisms that describe the potential for migration and where the contamination may be transported.

- The locations of points of exposure where individuals or populations may come in contact with a COC associated with a CAS.

- $\quad$ Routes of exposure where contaminants may enter the receptor.

If additional elements are identified during the investigation that are outside the scope of the CSM, the situation will be reviewed and a recommendation will be made as to how to proceed. In such cases, NDEP and NNSA/NSO will be notified and given the opportunity to comment on, and concur with, the recommendation.

The applicability of the CSM to each CAS is summarized in Figure A.2-1 and discussed below. Table A.2-1 provides information on CSM elements that will be used throughout the remaining steps of the DQO process. Figure A.2-2 represents site conditions applicable to this CSM.

\section{A.2.2.1 Contaminant Release}

The most likely locations of the contamination and releases to the environment are the soils directly below or adjacent to the CSM's surface and subsurface components (i.e., potential USTs, associated underground piping, concrete pads). The CSM accounts for potential releases resulting from overflow of system components that are present at the ground surface (e.g., fill ports for USTs) and surface spills. Any contaminants migrating from CASs, regardless of physical or chemical characteristics, are expected to exist at interfaces, and in the soil adjacent to disposal features in lateral and vertical directions. 


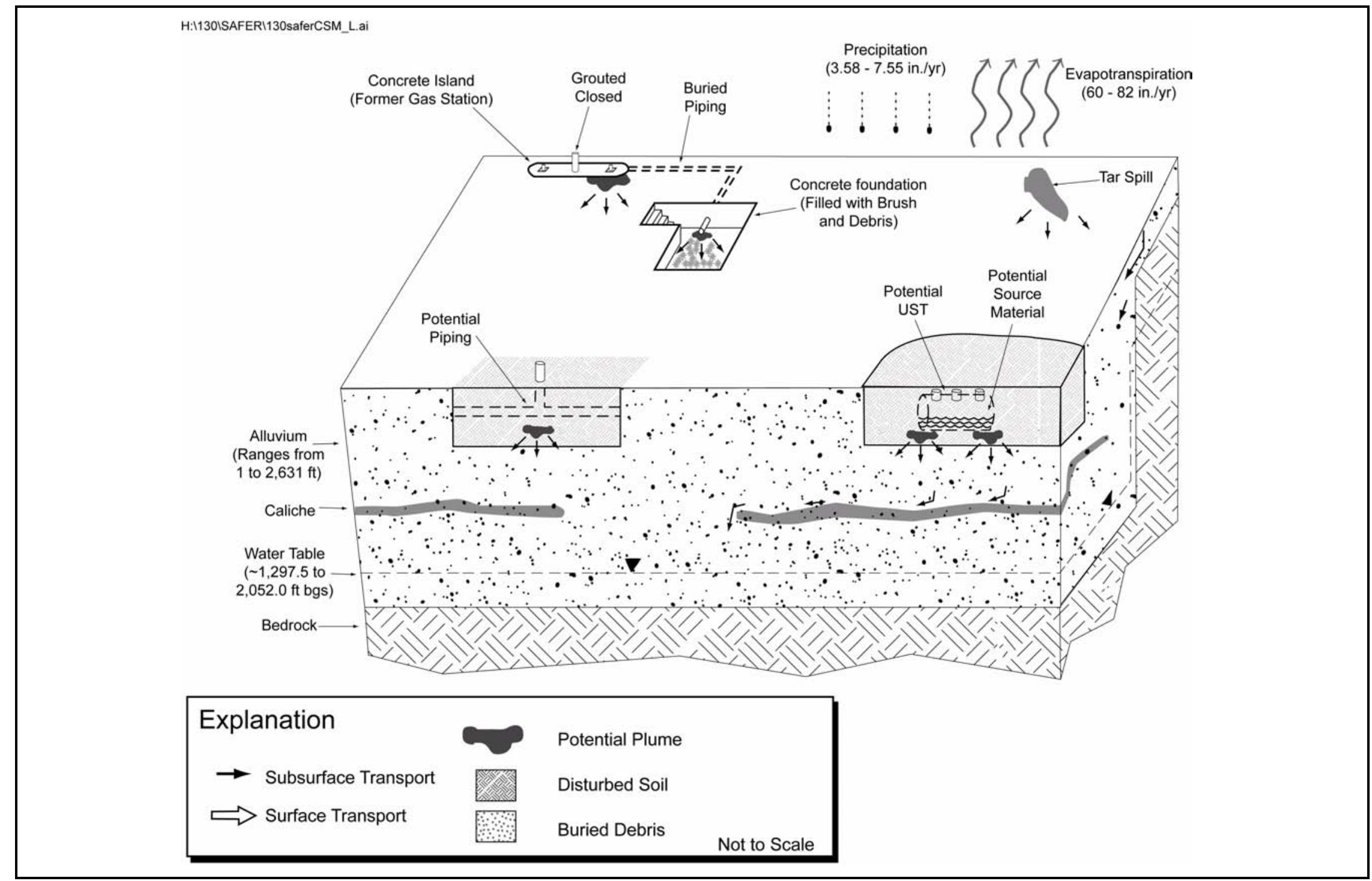

Figure A.2-1

Conceptual Site Model for CAU 130 CASs

\section{UNCONTROLLED When Printed}


Table A.2-1

Conceptual Site Model Description of Elements for Each CAS in CAU 130

(Page 1 of 2)

\begin{tabular}{|c|c|c|c|c|c|c|c|}
\hline CAS Identifier & $01-02-01$ & $07-02-01$ & $10-02-01$ & $20-02-03$ & $20-99-05$ & $22-02-02$ & $23-02-07$ \\
\hline CAS Description & $\begin{array}{l}\text { Underground } \\
\text { Storage Tank }\end{array}$ & $\begin{array}{l}\text { Underground } \\
\text { Storage Tanks }\end{array}$ & $\begin{array}{l}\text { Underground } \\
\text { Storage Tank }\end{array}$ & $\begin{array}{l}\text { Underground } \\
\text { Storage Tank }\end{array}$ & Tar Residue & $\begin{array}{l}\text { Buried UST } \\
\text { Piping }\end{array}$ & $\begin{array}{l}\text { Underground } \\
\text { Storage Tank }\end{array}$ \\
\hline Site Status & \multicolumn{7}{|c|}{ Sites are inactive and/or abandoned } \\
\hline Exposure Scenario & \multicolumn{6}{|c|}{ Occasional Use Area(s) } & $\begin{array}{c}\text { Industrial Use } \\
\text { Area }\end{array}$ \\
\hline $\begin{array}{l}\text { Sources of Potential } \\
\text { Soil Contamination }\end{array}$ & $\begin{array}{c}\text { Release } \\
\text { associated with } \\
\text { the contents of } \\
\text { UST }\end{array}$ & $\begin{array}{c}\text { Release } \\
\text { associated with } \\
\text { the contents of } \\
\text { USTs and/or } \\
\text { instruments } \\
\text { Release } \\
\text { associated with } \\
\text { lead brick(s), } \\
\text { subsurface piping }\end{array}$ & $\begin{array}{c}\text { Release } \\
\text { associated with } \\
\text { the contents of } \\
\text { UST }\end{array}$ & $\begin{array}{c}\text { Release } \\
\text { associated with } \\
\text { the contents of } \\
\text { UST }\end{array}$ & $\begin{array}{c}\text { Release } \\
\text { associated with a } \\
\text { tar residue }\end{array}$ & $\begin{array}{c}\text { Release } \\
\text { associated with } \\
\text { the buried UST } \\
\text { piping }\end{array}$ & $\begin{array}{c}\text { Release } \\
\text { associated with } \\
\text { UST }\end{array}$ \\
\hline $\begin{array}{l}\text { Location of } \\
\text { Contamination/ } \\
\text { Release Point }\end{array}$ & $\begin{array}{c}\text { Surface (overfills) } \\
\text { and subsurface } \\
\text { (leaks) at or near } \\
\text { UST }\end{array}$ & $\begin{array}{c}\text { Surface and } \\
\text { subsurface at or } \\
\text { near Station 7-235, } \\
\text { UST and/or } \\
\text { instrumentation, } \\
\text { lead brick(s), } \\
\text { subsurface piping }\end{array}$ & $\begin{array}{l}\text { Surface (overfills) } \\
\text { and subsurface } \\
\text { (leaks) at or near } \\
\text { UST }\end{array}$ & $\begin{array}{c}\text { Surface (overfills) } \\
\text { and subsurface } \\
\text { (leaks) at or near } \\
\text { UST }\end{array}$ & $\begin{array}{c}\text { Surface and } \\
\text { shallow } \\
\text { subsurface at or } \\
\text { near tar }\end{array}$ & $\begin{array}{c}\text { Surface and } \\
\text { subsurface at or } \\
\text { near buried UST } \\
\text { piping and } \\
\text { concrete } \\
\text { structures }\end{array}$ & $\begin{array}{c}\text { Subsurface } \\
\text { (leaks) at or near } \\
\text { UST }\end{array}$ \\
\hline Amount Released & Unknown & Unknown & Unknown & Unknown & Unknown & Unknown & Unknown \\
\hline Affected Media & \multicolumn{7}{|c|}{ Surface and shallow subsurface soil; debris such as concrete } \\
\hline $\begin{array}{c}\text { Potential } \\
\text { Contaminants }\end{array}$ & $\begin{array}{l}\text { VOCs, SVOCs, } \\
\text { TPH-GRO/DRO, } \\
\text { RCRA Metals, } \\
\text { Radionuclides }\end{array}$ & $\begin{array}{c}\text { VOCs, SVOCs, } \\
\text { RCRA Metals, } \\
\text { PCBs, } \\
\text { Radionuclides }\end{array}$ & $\begin{array}{c}\text { VOCs, SVOCs, } \\
\text { TPH-DRO/GRO, } \\
\text { RCRA Metals, } \\
\text { PCBs, } \\
\text { Radionuclides }\end{array}$ & $\begin{array}{l}\text { VOC, SVOCs, } \\
\text { TPH-DRO/ GRO, } \\
\text { RCRA Metals, } \\
\text { Radionuclides }\end{array}$ & $\begin{array}{l}\text { VOCs, SVOCs, } \\
\text { TPH-DRO }\end{array}$ & $\begin{array}{c}\text { VOCs, SVOCs, } \\
\text { TPH-GRO/DRO, } \\
\text { RCRA Metals }\end{array}$ & $\begin{array}{c}\text { VOCs, SVOCs, } \\
\text { TPH-DRO/GRO, } \\
\text { PCBs, RCRA } \\
\text { Metals }\end{array}$ \\
\hline
\end{tabular}

\section{UNCONTROLLED When Printed}


Table A.2-1

Conceptual Site Model Description of Elements for Each CAS in CAU 130

(Page 2 of 2)

\begin{tabular}{|c|c|c|c|c|c|c|c|}
\hline CAS Identifier & $01-02-01$ & $07-02-01$ & $10-02-01$ & $20-02-03$ & 20-99-05 & $22-02-02$ & 23-02-07 \\
\hline CAS Description & $\begin{array}{l}\text { Underground } \\
\text { Storage Tank }\end{array}$ & $\begin{array}{l}\text { Underground } \\
\text { Storage Tanks }\end{array}$ & $\begin{array}{l}\text { Underground } \\
\text { Storage Tank }\end{array}$ & $\begin{array}{l}\text { Underground } \\
\text { Storage Tank }\end{array}$ & Tar Residue & $\begin{array}{l}\text { Buried UST } \\
\text { Piping }\end{array}$ & $\begin{array}{l}\text { Underground } \\
\text { Storage Tank }\end{array}$ \\
\hline $\begin{array}{c}\text { Transport } \\
\text { Mechanisms }\end{array}$ & \multicolumn{7}{|c|}{$\begin{array}{c}\text { Percolation of precipitation through subsurface media serves as the major driving force for migration of contaminants. However, due to the arid } \\
\text { environment of the NTS, percolation of precipitation is very small and vertical migration of contaminants has been shown to be limited. Surface water } \\
\text { runoff may provide for the transportation of some contaminants beyond the initial footprint of the CAS. }\end{array}$} \\
\hline $\begin{array}{l}\text { Lateral and Vertical } \\
\text { Extent of } \\
\text { Contamination }\end{array}$ & \multicolumn{7}{|c|}{$\begin{array}{l}\text { Contamination, if present, is expected to be contiguous to the release points. Concentrations are expected to decrease with distance and depth from the } \\
\text { source. Groundwater contamination is not expected. Lateral and vertical extent of COC contamination is assumed to be within the spatial boundaries. }\end{array}$} \\
\hline Exposure Pathways & \multicolumn{7}{|c|}{$\begin{array}{l}\text { The potential for contamination exposure is limited to industrial and construction workers, and military personnel conducting training. These human } \\
\text { receptors may be exposed to COPCs through oral ingestion, inhalation, dermal contact (absorption) of soil and/or debris due to inadvertent disturbance } \\
\text { of these materials or irradiation by radioactive materials. }\end{array}$} \\
\hline
\end{tabular}

$\mathrm{COC}=$ Contaminant of concern COPC $=$ Contaminant of potential concern $\mathrm{DRO}=$ Diesel-range organics $\mathrm{GRO}=$ Gasoline-range organics NTS = Nevada Test Site

$\mathrm{PCB}=$ Polychlorinated biphenyl
RCRA = Resource Conservation and Recovery Act

SVOC = Semivolatile organic compound

$\mathrm{TPH}=$ Total petroleum hydrocarbons

UST = Underground storage tank

VOC $=$ Volatile organic compound 


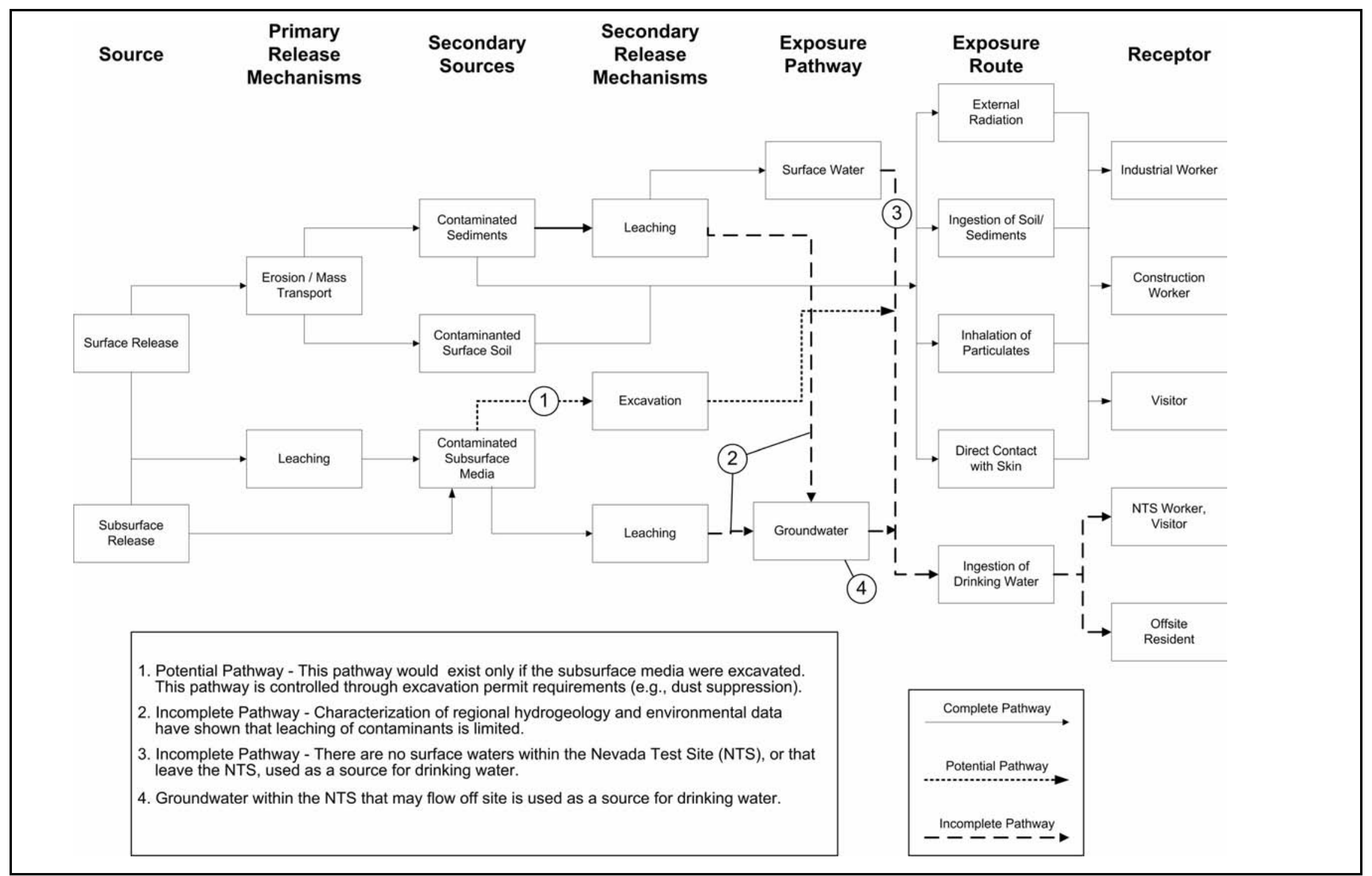

Figure A.2-2

Conceptual Site Model Diagram for CAU 130, Storage Tanks 


\section{A.2.2.2 Potential Contaminants}

The COPCs were identified during the planning process through the review of site history, process knowledge, personal interviews, past investigation efforts (where available), and inferred activities associated with the CASs. Because complete information regarding activities performed at the CAU 130 sites is not available, contaminants detected at similar NTS sites were included in the contaminant lists to reduce uncertainty. The list of COPCs is intended to encompass all of the contaminants that could potentially be present at each CAS. The COPCs applicable to Decision I environmental samples from each of the CASs of CAU 130 are defined as the constituents reported from the analytical methods stipulated in Table A.2-2.

During the review of site history documentation, process knowledge information, personal interviews, past investigation efforts (where available), and inferred activities associated with the CASs, some of the COPCs were identified as targeted contaminants at specific CASs. Targeted contaminants are those COPCs for which evidence in the available site and process information suggests that they may be reasonably suspected to be present at a given CAS. The targeted contaminants are required to meet a more stringent completeness criteria than other COPCs thus providing greater protection against a decision error (see Section A.2.2). Targeted contaminants for each CAU 130 CAS are identified in Table A.2-3.

\section{A.2.2.3 Contaminant Characteristics}

Contaminant characteristics include, but are not limited to: solubility, density, and adsorption potential. In general, contaminants with large particle size, low solubility, high affinity for media, and/or high density can be expected to be found relatively close to release points. Contaminants with small particle size, high solubility, low affinity for media, and/or low density are found further from release points or in low areas where evaporation of ponding will concentrate dissolved constituents. Volatile COPCs may impact the air, and COPCs contained in a liquid or are "dusts" dissolved by rainwater may infiltrate the subsoil. 
Table A.2-2

\section{Analytical Program ${ }^{a}$}

(Includes Waste Characterization Analyses)

\begin{tabular}{|c|c|c|c|c|c|c|c|}
\hline Analyses & $\begin{array}{c}\text { CAS } \\
01-02-01\end{array}$ & \begin{tabular}{|c|} 
CAS \\
$07-02-01$
\end{tabular} & $\begin{array}{c}\text { CAS } \\
10-02-01\end{array}$ & $\begin{array}{c}\text { CAS } \\
20-02-03\end{array}$ & $\begin{array}{c}\text { CAS } \\
20-99-05\end{array}$ & $\begin{array}{c}\text { CAS } \\
22-02-02\end{array}$ & $\begin{array}{c}\text { CAS } \\
23-02-07\end{array}$ \\
\hline \multicolumn{8}{|c|}{ Organic Contaminants of Potential Concern (COPCs) } \\
\hline Volatile Organic Compounds & $\mathrm{X}$ & $\mathrm{X}$ & $\mathrm{X}$ & $\mathrm{X}$ & $\mathrm{X}$ & $\mathrm{X}$ & $\mathrm{X}$ \\
\hline Semivolatile Organic Compounds & $\mathrm{X}$ & $\mathrm{X}$ & $\mathrm{X}$ & $\mathrm{X}$ & $\mathrm{X}$ & $\mathrm{X}$ & $\mathrm{X}$ \\
\hline $\begin{array}{l}\text { Total Petroleum Hydrocarbons- } \\
\text { Gasoline-Range Organics }\end{array}$ & $\mathrm{X}$ & $\mathrm{X}$ & 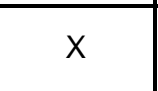 & $\mathrm{X}$ & -- & $\mathrm{X}$ & $\mathrm{X}$ \\
\hline $\begin{array}{l}\text { Total Petroleum Hydrocarbons- } \\
\text { Diesel-Range Organics }\end{array}$ & $\mathrm{X}$ & $\mathrm{X}$ & $\mathrm{X}$ & $\mathrm{X}$ & $\mathrm{X}$ & $\mathrm{X}$ & $\mathrm{X}$ \\
\hline Polychlorinated Biphenyls & -- & $\mathrm{x}$ & $\mathrm{X}$ & -- & -- & -- & $x$ \\
\hline \multicolumn{8}{|c|}{ Inorganic COPCs } \\
\hline $\begin{array}{c}\text { Resource Conservation and Recovery Act } \\
\text { Metals }\end{array}$ & $x$ & $x$ & $x$ & $x$ & $x$ & $x$ & $x$ \\
\hline \multicolumn{8}{|c|}{ Radionuclide COPCs } \\
\hline$\overline{\text { Gamma Spectroscopy }^{b}}$ & $\overline{\mathrm{X}}$ & $\overline{\mathrm{X}}$ & $\overline{\mathrm{X}}$ & $\overline{\mathrm{X}}$ & $\overline{-1-}$ & $\overline{\mathrm{X}}$ & $\overline{\mathrm{X}}$ \\
\hline \multicolumn{8}{|c|}{ Waste Characterization Analyses (if necessary) } \\
\hline$\overline{\text { TCLP VOCS }}$ & $\overline{\mathrm{X}}$ & $\overline{\mathrm{X}}$ & $\overline{\bar{X}}$ & $\overline{\mathrm{X}}$ & $\overline{\bar{X}}$ & $\overline{\mathrm{X}}$ & $\overline{\mathrm{X}}$ \\
\hline TCLP SVOCS & $\mathrm{X}$ & $x$ & $\mathrm{x}$ & $x$ & $\mathrm{x}$ & $\mathrm{x}$ & $\mathrm{x}$ \\
\hline TCLP RCRA Metals & $\mathrm{X}$ & $x$ & $\mathrm{x}$ & $x$ & $\mathrm{x}$ & $x$ & $\mathrm{x}$ \\
\hline Total Pesticides & $\mathrm{X}$ & $\mathrm{X}$ & $\mathrm{X}$ & $\mathrm{X}$ & $\mathrm{X}$ & $\mathrm{X}$ & $\mathrm{X}$ \\
\hline Total Herbicides & $\mathrm{x}$ & $\mathrm{x}$ & $\mathrm{X}$ & $\mathrm{x}$ & $\mathrm{X}$ & $\mathrm{x}$ & $\mathrm{X}$ \\
\hline PCBS & $\mathrm{X}$ & $x$ & $\mathrm{X}$ & $x$ & $\mathrm{X}$ & $\mathrm{x}$ & $\mathrm{X}$ \\
\hline TPH-DRO & $x$ & $x$ & $\mathrm{x}$ & $x$ & $\mathrm{X}$ & $x$ & $\bar{x}$ \\
\hline TPH-GRO & $x$ & $x$ & $x$ & $x$ & $\mathrm{x}$ & $x$ & $x$ \\
\hline Gamma Spectroscopy & $\mathrm{X}$ & $x$ & $\mathrm{X}$ & $x$ & $x$ & $x$ & $\bar{x}$ \\
\hline Isotopic Uranium & $x$ & $x$ & $\mathrm{x}$ & $x$ & $\bar{x}$ & $x$ & $\bar{x}$ \\
\hline Isotopic Plutonium & $\mathrm{X}$ & $\mathrm{X}$ & $\mathrm{X}$ & $\mathrm{X}$ & $\mathrm{X}$ & $x$ & $\mathrm{X}$ \\
\hline Strontium-90 & $x$ & $\mathrm{x}$ & $\mathrm{X}$ & $\mathrm{X}$ & $\mathrm{x}$ & $x$ & $x$ \\
\hline Gross Alpha/Gross Beta ${ }^{c}$ & $\mathrm{X}$ & $\mathrm{X}$ & $\mathrm{X}$ & $\mathrm{X}$ & $\mathrm{X}$ & $\mathrm{X}$ & $\mathrm{X}$ \\
\hline Tritium $^{c}$ & $x$ & $x$ & $x$ & $\mathrm{x}$ & $\mathrm{X}$ & $x$ & $\mathrm{X}$ \\
\hline
\end{tabular}

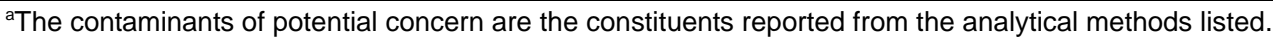

${ }^{b}$ Results of gamma analysis will be used to determine whether further radioanalytical analysis is warranted.

${ }^{\circ} \mathrm{Gross}$ alpha/gross beta and tritium will only be taken on decontamination rinsate.

DRO = Diesel-range organics

GRO = Gasoline-range organics

PCB $=$ Polychlorinated biphenyl

RCRA = Resource Conservation and Recovery Act

$X=$ Required analytical method

$--=$ Not required
SVOC $=$ Semivolatile organic compound

TCLP = Toxicity Characteristic Leaching Procedure

$\mathrm{VOC}=$ Volatile organic compound 
Table A.2-3

Targeted Contaminants for CAU 130

\begin{tabular}{|c|c|c|}
\hline $\begin{array}{c}\text { Corrective Action } \\
\text { Site }\end{array}$ & $\begin{array}{l}\text { Targeted Chemical } \\
\text { Contaminants }\end{array}$ & $\begin{array}{c}\text { Targeted } \\
\text { Radiological } \\
\text { Contaminants }\end{array}$ \\
\hline 01-02-01 & $\begin{array}{c}\text { VOCS, SVOCs, } \\
\text { TPH-DRO }\end{array}$ & None \\
\hline 07-02-01 & $\begin{array}{l}\text { Lead (associated with } \\
\text { lead brick[s]) }\end{array}$ & None \\
\hline $10-02-01$ & None & None \\
\hline $20-02-03$ & None & None \\
\hline 20-99-05 & $\begin{array}{c}\text { VOCs, SVOCs, } \\
\text { TPH-DRO }\end{array}$ & None \\
\hline $22-02-02$ & $\begin{array}{c}\text { VOCs, SVOCs, } \\
\text { TPH-GRO/DRO, Lead } \\
\text { (associated with } \\
\text { leaded gasoline) }\end{array}$ & None \\
\hline $23-02-07$ & $\begin{array}{c}\text { VOCs, SVOCs, } \\
\text { TPH-DRO }\end{array}$ & None \\
\hline $\begin{array}{l}\text { DRO = Diesel-range orga } \\
\text { GRO = Gasoline-range o } \\
\text { SVOC = Semivolatile org }\end{array}$ & $\begin{array}{l}\text { cs } \\
\text { compound }\end{array}$ & $\begin{array}{l}\text { petroleum hydrocar } \\
\text { tile organic compour }\end{array}$ \\
\hline
\end{tabular}

\section{A.2.2.4 Site Characteristics}

Site characteristics are defined by the interaction of physical, topographical, and meteorological attributes and properties. Physical properties include permeability, porosity, hydraulic conductivity, degree of saturation, sorting, chemical composition, and organic content. Topographical and meteorological properties and attributes include slope stability, precipitation frequency and amounts, precipitation runoff pathways, drainage channels and ephemeral streams, and evapotranspiration potential.

The structural geology of the NTS is complex. Thousands of normal faults throughout the area are responsible for the main characteristics of the Basin and Range topography (Winograd and Thordarson, 1975). Along with the normal faults, strike-slip faults and shear zones cut and offset thrust faults in several places within the NTS. Because the complexity of the structural geology, regional movement of groundwater may be influenced. 


\section{A.2.2.5 Migration Pathways and Transport Mechanisms}

Migration pathways of potential contaminants include lateral migration across

surface soils/sediments and vertical migration of potential contaminants into and through subsurface soils.

Infiltration and percolation of precipitation serves as a driving force for downward migration of contaminants. Groundwater, however, is not expected to be impacted in the CAU 130 Areas $(1,7,10$, 20 , 22, or 23) of the NTS. The inflitration of precipitation through subsurface media typically serves as the major driving force for migration of contaminants. Because of the arid environment of the NTS, percolation of precipitation is small, and migration of potential contaminants has been shown to be limited. Evaporation potentials at the NTS range between 60 to 82 inches per year (in./yr), which significantly exceeds the NTS annual average precipitation. The annual average precipitation across the NTS ranges from 3.58 to $7.55 \mathrm{in./yr} \mathrm{(ARL/SORD,} \mathrm{2006).}$

Potential contaminants can be expected to be found relatively close to their release points, or in low areas where settling may occur and evaporation may concentrate the constituents. Given the relatively shallow relief at these CASs, lateral migration of potential contaminants of any major distance is unlikely. Because of the expected limited mobility, the affected media is typically the surface and shallow subsurface soil. Concentrations are expected to decrease with horizontal and vertical distance from the potential sources.

Infiltration of COPCs beyond shallow subsurface soil is not a concern at these CASs. While potential contaminants within weathered hydrocarbon spill/release may cover visible areas, they tend to be present in higher concentrations near the point of discharge and decrease with increased distance, both laterally and vertically.

\section{A.2.2.6 Exposure Scenarios}

Human receptors may be exposed to COPCs through oral ingestion, inhalation, dermal contact (absorption) of soil or debris due to inadvertent disturbance of these materials or irradiation by radioactive materials. The land-use and exposure scenarios for the CAU 130 CASs are listed in Table A.2-4. These are based on NTS current and future land use (DOE/NV, 1998). Although all CASs are located in areas where structures from past activities exist, no facilities are present that 
would allow these to be used as an assigned work station for NTS site personnel. However, as site personnel may periodically perform work at these sites, they are considered to be remote work areas. There is still the possibility, however, that site workers could occupy these locations on an occasional and temporary basis such as short-term maintenance activities or a military exercise. Therefore, these sites are classified as occasional work areas and industrial work areas.

Table A.2-4

Land Use and Exposure Scenarios

\begin{tabular}{|c|c|c|}
\hline $\begin{array}{l}\text { Corrective } \\
\text { Action Site }\end{array}$ & Record of Decision Land Use Zone & Exposure Scenario \\
\hline $23-02-07$ & $\begin{array}{l}\text { Reserved Zone } \\
\text { This area includes land and facilities that provide } \\
\text { widespread flexible support for diverse short-term } \\
\text { testing and experimentation. The reserved zone is also } \\
\text { used for short duration exercises and training such as } \\
\text { nuclear emergency response and Federal Radiological } \\
\text { Monitoring and Assessment Center training and } \\
\text { U.S. Department of Defense land-navigation exercises } \\
\text { and training. }\end{array}$ & $\begin{array}{c}\text { Industrial Area } \\
\text { Worker will be exposed to the site full time } \\
\text { (225 days per year, } 10 \text { hours per day for } \\
25 \text { years). Active powered buildings with } \\
\text { toilets are present at the site. }\end{array}$ \\
\hline $22-02-02$ & $\begin{array}{l}\text { Solar Enterprise Zone } \\
\text { This area is designated for the development of a solar } \\
\text { power generation facility, and light industrial equipment } \\
\text { and commercial manufacturing capability. }\end{array}$ & \multirow{3}{*}{$\begin{array}{l}\text { Occasional Use Area } \\
\text { Worker will be exposed to the site occasionally } \\
\text { (up to } 80 \text { hours per year for } 5 \text { years). Site } \\
\text { structures are not present for shelter and } \\
\text { comfort of the worker }\end{array}$} \\
\hline $01-02-01$ & $\begin{array}{c}\text { Nuclear and High Explosives Test } \\
\text { This area is designated within the Nuclear Test Zone for } \\
\text { additional underground nuclear weapons tests and } \\
\text { outdoor high-explosive tests. This zone includes } \\
\text { compatible defense and nondefense research, } \\
\text { development, and testing activities. }\end{array}$ & \\
\hline $\begin{array}{l}07-02-01 \\
10-02-01 \\
20-02-03 \\
20-99-05\end{array}$ & $\begin{array}{l}\text { Nuclear Test } \\
\text { This area is reserved for dynamic experiments, } \\
\text { hydrodynamic tests, and underground nuclear weapons } \\
\text { and weapons effects tests. This zone includes } \\
\text { compatible defense and nondefense research, } \\
\text { development, and testing activities. }\end{array}$ & \\
\hline
\end{tabular}




\section{A.3.0 Step 2 - Identify the Goal of the Study}

Step 2 of the DQO process states how environmental data will be used in meeting objectives and solving the problem, identifies study questions or decision statement(s), and considers alternative outcomes or actions that can occur upon answering the question(s). Figure A.3-1 depicts the sequential flow of questions, answers, and action alternatives required to fulfill the objectives of the SAFER process.

\section{A.3.1 Decision Statements}

The Decision I statement is: “Is any COC present in environmental media within the CAS?” For judgmental sampling design, any analytical result for a COPC above the FAL will result in that COPC being designated as a COC. A COC may also be defined as a contaminant that, in combination with other like contaminants, is determined to jointly pose an unacceptable risk based on a multiple constituent analysis (NNSA/NSO, 2006). If a COC is detected, then Decision II must be resolved.

The Decision II statement is: "If a COC is present, is sufficient information available to meet the closure objectives?” Sufficient information is defined to include:

- Identifying the volume of media containing any COC bounded by analytical sample results in lateral and vertical directions.

- The information needed to characterize IDW and potential remediation waste for disposal.

- The information needed to evaluate the feasibility of remediation alternatives (bioassessment if natural attenuation or biodegradation is considered, and geotechnical data if construction or evaluation of barriers is considered).

A corrective action will be determined for any site containing a COC. The evaluation of the need for corrective action will include the potential for wastes that are present at a site to cause the future contamination of site environmental media if the wastes were to be released. To evaluate the potential for UST contents to result in the introduction of a COC to the surrounding environmental media, the following conservative assumptions were made:

- Any containment would fail at some point, and the contents would be released to the surrounding media. 


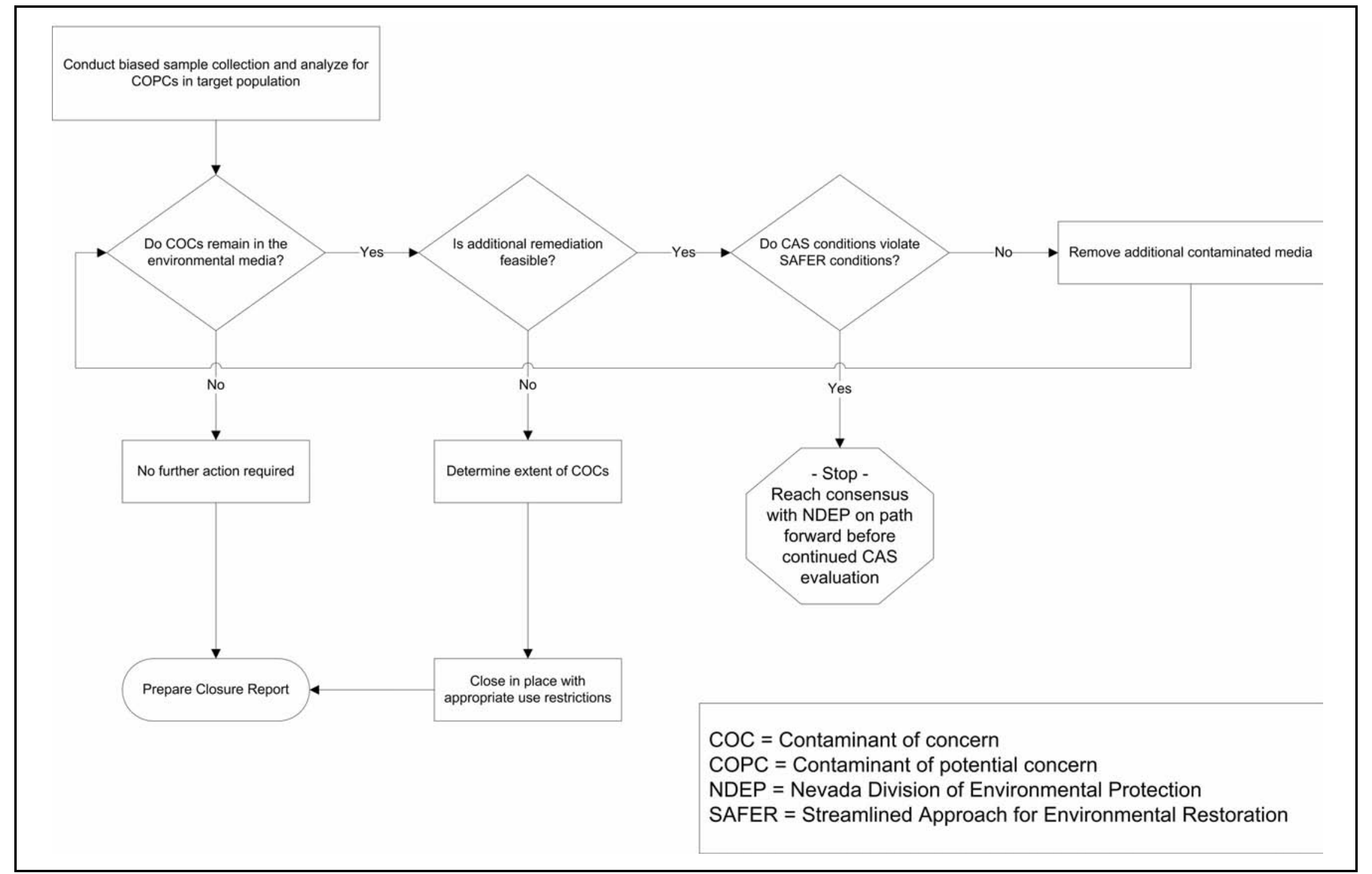

Figure A.3-1

SAFER Closure Decision Process for CAU 130 
- The resulting concentration of contaminants in the surrounding media would be equal to the concentration of contaminants in the tank waste.

- Any liquid contaminant in the UST exceeding the RCRA toxicity characteristic concentration would result in COCs in the surrounding media.

- If it is determined that the tar at CAS 20-99-05 is PSM (i.e., the tar contains a contaminant exceeding an equivalent FAL concentration), then a corrective action would be required (e.g., removal of the tar, if feasible).

The criteria for a non-liquid waste to be PSM is that it contains a contaminant exceeding an equivalent FAL concentration. The criteria for a liquid to be PSM is that it contains a contaminant concentration exceeding an equivalent toxicity characteristic action level. Any PSMs would require a corrective action.

If sufficient information is not available to meet the closure objectives, then site conditions will be re-evaluated and additional samples will be collected (as long as the scope of the investigation is not exceeded and any CSM assumption has not been shown to be incorrect).

\section{A.3.2 Alternative Actions to the Decisions}

This section identifies actions that may be taken to solve the problem depending on the possible outcomes of the investigation.

\section{A.3.2.1 Alternative Actions to Decision I}

If no COC associated with a release from the CAS is detected, then further assessment of the CAS is not required, and the corrective action alternative of no further action will be selected. If a COC associated with a release from the CAS is detected, then additional sampling will be conducted to determine the extent of COC contamination. If the extent of the contamination is defined and additional remediation is feasible, then clean close the site by removing the contaminated media until all contamination has been removed. If the extent of contamination has been determined and additional remediation is not feasible, then the extent of contamination will be defined and the contaminated area will be closed in place with appropriate use restrictions. 
If the collection of verification samples confirms that all the contaminated media has been removed, then the clean closure objectives will have been met. If contamination still exists and additional remediation would violate the conditions of the SAFER, then work will stop and a consensus reached with NDEP on the path forward before continuing the investigation of the CAS.

\section{A.3.2.2 Alternative Actions to Decision II}

If sufficient information is available to define the extent of the COCs and confirm that closure objectives were met, then further assessment of the CAS is not required. If sufficient information is not available to define the extent of contamination or confirm that closure objectives were met, then additional samples will be collected until the extent is defined. 


\section{A.4.0 Step 3 - Identify Information Inputs}

Step 3 of the DQO process identifies the information needed, determines sources for information, and identifies sampling and analysis methods that will allow reliable comparisons with FALs.

\section{A.4.1 Information Needs}

To resolve Decision I (determine whether a COC is present at a given CAS), samples need to be collected and analyzed following these two criteria:

- Samples must be collected in areas most likely to contain a COC (judgmental sampling).

- The analytical suite selected must be sufficient to identify any COCs present in the samples.

To resolve Decision II (determine whether sufficient information is available to confirm that closure objectives were met at each CAS), samples must be collected and analyzed to meet the following criteria:

- Samples must be collected in areas contiguous to the contamination but where contaminant concentrations are below FALs.

- Samples of the waste or environmental media must provide sufficient information to characterize the IDW for disposal.

- Samples of the waste or environmental media must provide sufficient information to determine potential remediation waste types.

- Samples of the waste in tanks must provide sufficient information to determine whether they contain PSM.

- Appropriate samples must be submitted to evaluate the feasibility of remediation alternatives (e.g., bioassessment if natural attenuation or biodegradation is considered, and geotechnical data if construction or evaluation of barriers is considered).

- The analytical suites selected must be sufficient to detect contaminants at concentrations equal to or less than their corresponding FALs. 


\section{A.4.2 Sources of Information}

Information to satisfy Decision I and Decision II will be generated by collecting environmental samples using grab sampling, hand auguring, backhoe excavation, or other appropriate sampling methods. These samples will be submitted to analytical laboratories meeting the quality criteria stipulated in the Industrial Sites QAPP (NNSA/NV, 2002). Only validated data from analytical laboratories will be used to make DQO decisions. Sample collection and handling activities will follow standard procedures.

\section{A.4.2.1 Sample Locations}

Design of the sampling approaches for the CAU 130 CASs must ensure that the data collected are of sufficient quantity and quality to support the selection of the corrective action alternatives (EPA, 2002). To meet this objective, the samples collected from each site should be from locations that most likely contain a COC, if present (judgmental), and properly represent any contamination at the CAS. These sample locations, therefore, can be selected by means of biasing factors used in judgmental sampling (e.g., a stain, likely containing a spilled substance). Because there is enough information available among the CAU 130 CASs, judgmental sampling approach are used for the CAI. Although some randomly chosen locations may be specified if biasing factors are absent, the sampling approach is considered judgmental.

\section{A.4.2.1.1 Judgmental Approach for Sampling Location Selection}

Decision I sample locations at CAU 130 CASs will be determined based upon the likelihood of the soil containing a COC, if present. Analytical suites for Decision I samples will include all COPCs identified in Table A.2-2.

The following field-screening biasing factors may be used to select biased sample locations at CAU 130:

- Walkover surface area radiological surveys: A radiological survey instrument will be used to detect locations of elevated radioactivity as permitted by terrain and field conditions.

- Documented process knowledge on source and location of release (e.g., volume). 
- Stains: Any spot or area on the soil surface that may indicate the presence of a potentially hazardous liquid. Typically, stains indicate an organic liquid such as oil.

- Geophysical anomalies: Any location identified during geophysical surveys that had results indicating surface or subsurface materials existed, and were not consistent with the natural surroundings (e.g., UST, buried concrete or metal, surface metallic objects).

- Drums, containers, equipment, or debris: Materials that may have been used at, or added to, a location, and that may have contained or come in contact with hazardous or radioactive substances at some point during their use.

- Lithology: Locations where variations in lithology (soil or rock) indicate that different conditions or materials exist.

- Preselected areas based on process knowledge of the site: Locations for which evidence such as historical photographs, experience from previous investigations, or interviewee's input exists that a release of hazardous or radioactive substances may have occurred.

- Preselected areas based on process knowledge of the contaminant(s): Locations that may reasonably have received contamination, selected on the basis of the chemical and/or physical properties of the contaminant(s) in that environmental setting.

- Previous sample results from the site being investigated.

- Experience and data from investigations of similar sites.

- Visual indicators such as discoloration, textural discontinuities, disturbance of native soils, or any other indication of potential contamination.

- Presence of debris, waste, or equipment.

- Odor.

- Physical and chemical characteristics of contaminants.

- Other biasing factors: Factors not previously defined for the CAI that become evident once the investigation of the site is under way.

Decision II sample step-out locations will be selected based on the CSM, biasing factors, and existing data. Analytical suites will include those parameters that exceeded FALs (i.e., COCs) in prior samples. Biasing factors to support Decision II sample locations include Decision I biasing factors plus available analytical results. 


\section{A.4.2.2 Analytical Methods}

Analytical methods are available to provide the data needed to resolve the decision statements. The analytical methods and laboratory requirements (e.g., detection limits, precision, and accuracy) are provided in Tables 3-4 and 3-5 of the CAU 130 SAFER Plan. 


\section{A.5.0 Step 4 - Define the Boundaries of the Study}

Step 4 of the DQO process defines the target population of interest and its relevant spatial boundaries, specifies temporal and other practical constraints associated with sample/data collection, and defines the sampling units on which decisions or estimates will be made.

\section{A.5.1 Target Populations of Interest}

The population of interest to resolve Decision I ("Is any COC present in environmental media within the CAS?”) is any location within the site that is contaminated with any contaminant above a FAL (judgmental sampling). The populations of interest to resolve Decision II ("If a COC is present, is sufficient information available to evaluate potential corrective action alternatives?”) are:

- Each one of a set of locations bounding contamination in lateral and vertical directions.

- Investigation-derived waste or environmental media that must be characterized for disposal.

- Potential remediation waste.

- Environmental media where natural attenuation or biodegradation or construction/evaluation of barriers is considered.

\section{A.5.2 Spatial Boundaries}

Spatial boundaries are the maximum lateral and vertical extent of expected contamination at each CAS, as shown in Table A.5-1. Contamination found beyond these boundaries may indicate a flaw in the CSM and may require re-evaluation of the CSM before the investigation could continue. Each CAS is considered geographically independent, and intrusive activities are not intended to extend into the boundaries of neighboring CASs. 
Table A.5-1

Spatial Boundaries of CAU 130 CASs

\begin{tabular}{|c|c|}
\hline Corrective Action Site & Spatial Boundaries \\
\hline 01-02-01 & $\begin{array}{c}\text { The footprint of the gas pipe and excavated area, plus an approximate } \\
100 \text {-foot (ft) lateral buffer, not including Test Buildings 1-31.1e1 and 1-31-4b1; } \\
15 \mathrm{ft} \text { below ground surface (bgs) vertically }\end{array}$ \\
\hline 07-02-01 & $\begin{array}{l}\text { The footprint of Station 7-235 and the two mounds, plus an approximate } \\
100 \text {-ft lateral buffer; } 15 \mathrm{ft} \text { bgs vertically }\end{array}$ \\
\hline $10-02-01$ & $\begin{array}{l}\text { The footprint of the concrete pad and visible piping, plus an approximate } \\
100 \text {-ft lateral buffer; } 15 \mathrm{ft} \text { bgs vertically }\end{array}$ \\
\hline $20-02-03$ & $\begin{array}{l}\text { Engineered planned location of underground storage tank (UST) and geophysical } \\
\text { located anomaly, plus an approximate } 100-\mathrm{ft} \text { lateral buffer from each location; } \\
15 \mathrm{ft} \text { bgs vertically }\end{array}$ \\
\hline 20-99-05 & $\begin{array}{l}\text { The footprint of the tar residue, plus an approximate 100-ft lateral buffer; } \\
\qquad 15 \mathrm{ft} \text { bgs vertically }\end{array}$ \\
\hline $22-02-02$ & $\begin{array}{l}\text { The concrete gas island, concrete foundation with steps, and underground piping, } \\
\text { plus an approximate } 100 \text {-ft lateral buffer; } 15 \mathrm{ft} \text { bgs vertically }\end{array}$ \\
\hline $23-02-07$ & Location of the UST, plus an approximate 100 -ft lateral buffer; $15 \mathrm{ft}$ bgs vertically \\
\hline
\end{tabular}

\section{A.5.3 Practical Constraints}

Practical constraints such as military activities at the NTS, utilities, threatened or endangered animals and plants, unstable or steep terrain, and/or access restrictions may affect the ability to investigate this site. The practical constraints associated with the investigation of the CAU 130 CASs are summarized in Table A.5-2.

\section{A.5.4 Define the Sampling Units}

The scale of decision making in Decision I is defined as the CAS. Any COC detected at any location within the CAS will cause the determination that the CAS is contaminated and needs further evaluation. The scale of decision making for Decision II is defined as a contiguous area contaminated with any COC originating from the CAS. Resolution of Decision II requires this contiguous area to be bounded laterally and vertically. 
Table A.5-2

Practical Constraints for the CAU 130 Field Investigation

\begin{tabular}{||c|c|c|}
\hline Corrective Action Site & Practical Constraints \\
\hline \hline $01-02-01$ & $\begin{array}{r}\text { Weather (i.e., high winds, rain, lightning, extreme heat); Test Buildings 1-31.1e1 and } \\
\text { 1-31-4b1 boundary; underground utilities; and loose and unconsolidated terrain }\end{array}$ \\
\hline $07-02-01$ & $\begin{array}{r}\text { Weather (i.e., high winds, rain, lightning, extreme heat); posted "Contamination Area"; } \\
\text { loose and unconsolidated terrain; and underground utilities }\end{array}$ \\
\hline $10-02-01$ & $\begin{array}{r}\text { Weather (i.e., high winds, rain, lightning, extreme heat); underground utilities; and loose } \\
\text { and unconsolidated terrain }\end{array}$ \\
\hline $20-02-03$ & $\begin{array}{c}\text { Weather (i.e., high winds, rain, lightning, extreme heat); overhead and below ground } \\
\text { utilities; loose and uneven terrain; located near subsided crater and cliff to the west of CAS }\end{array}$ \\
\hline $20-99-05$ & $\begin{array}{c}\text { Weather (i.e., high winds, rain, lightning, extreme heat); loose and uneven terrain } \\
\text { 22-02-02 }\end{array}$ & $\begin{array}{c}\text { Weather (i.e, high winds, rain, lightning, extreme heat); located within the habitat range of } \\
\text { the desert tortoise; underground utilities associated with gas station and former } \\
\text { underground storage tanks and uneven terrain }\end{array}$ \\
\hline $2-02-07$ & $\begin{array}{c}\text { Weather (i.e., high winds, rain, lightning, warm temperatures); underground utilities, and } \\
\text { uneven terrain }\end{array}$ \\
\hline
\end{tabular}

${ }^{a}$ Mojave Desert population of the desert tortoise is listed as a threatened species by the U.S. Fish and Wildlife Service (DOE/NV, 1996). 


\section{A.6.0 Step 5 - Develop the Analytic Approach}

Step 5 of the DQO process specifies appropriate population parameters for making decisions, defines action levels and generates an "If ... then ... else" decision rule that defines the conditions under which possible alternative actions will be chosen. This step also specifies the parameters that characterize the population of interest, specifies the FALs, and confirms that the analytical detection detection limits are capable of detecting FALs.

\section{A.6.1 Population Parameters}

For judgmental sampling results, the population parameter is the observed concentration of each contaminant from each individual analytical sample. Each sample result will be compared to the FALs to determine the appropriate resolution to Decision I and Decision II. For Decision I, a single sample result for any contaminant exceeding a FAL would cause a determination that a COC is present within the CAS.

The Decision II population parameter is an individual analytical result from a bounding sample. For Decision II, a single bounding sample result for any contaminant exceeding a FAL would cause a determination that the contamination is not bounded.

\section{A.6.2 Action Levels}

The PALs presented in this section are to be used for site screening purposes. They are not necessarily intended to be used as cleanup action levels or FALs. However, they are useful in screening out contaminants that are not present in sufficient concentrations to warrant further evaluation and, therefore, streamline the consideration of remedial alternatives. The risk-based corrective action (RBCA) process used to establish FALs is described in the Industrial Sites Project Establishment of Final Action Levels (NNSA/NSO, 2006). This process conforms with Nevada Administrative Code (NAC) Section 445A.227, which lists the requirements for sites with soil contamination (NAC, 2006a). For the evaluation of corrective actions, NAC Section 445A.22705 (NAC, 2006b) recommends the use of American Society for Testing and Materials (ASTM) Method E 1739-95 (ASTM, 1995) to "conduct an evaluation of the site, based on the risk it poses to 
public health and the environment, to determine the necessary remediation standards (i.e., FALs) or to establish that corrective action is not necessary."

This RBCA process defines three tiers (or levels) of evaluation involving increasingly sophisticated analyses:

- Tier 1 evaluation - Sample results from source areas (highest concentrations) are compared to action levels based on generic (non-site-specific) conditions (i.e., the PALs established in the SAFER Plan). The FALs may then be established as the Tier 1 action levels or the FALs may be calculated using a Tier 2 evaluation.

- Tier 2 evaluation - Conducted by calculating Tier 2 SSTLs using site-specific information as inputs to the same or similar methodology used to calculate Tier 1 action levels. The Tier 2 are then compared to individual sample results from reasonable points of exposure (as opposed to the source areas as is done in Tier 1) on a point-by-point basis. Total TPH concentrations will not be used for risk-based decisions under Tier 2 or Tier 3 . Rather, the individual COPC constituents of TPH-DRO will be compared to the SSTLs.

- Tier 3 evaluation - Conducted by calculating Tier 3 SSTLs on the basis of more sophisticated risk analyses using methodologies described in Method E 1739-95 that consider site-, pathway-, and receptor-specific parameters.

The comparison of laboratory results to FALs and the evaluation of potential corrective actions will be included in the investigation report. The FALs will be defined (along with the basis for their definition) in the investigation report.

\section{A.6.2.1 Chemical PALs}

Except as noted herein, the chemical PALs are defined as the EPA Region 9 Risk-Based Preliminary Remediation Goals (PRGs) for chemical contaminants in industrial soils (EPA, 2004). Background concentrations for RCRA metals and zinc will be used instead of PRGs when natural background concentrations exceed the PRG, as is often the case with arsenic on the NTS. Background is considered the average concentration plus two standard deviations of the average concentration for sediment samples collected by the Nevada Bureau of Mines and Geology throughout the Nevada Test and Training Range (formerly the Nellis Air Force Range) (NBMG, 1998; Moore, 1999). For detected chemical COPCs without established PRGs, the protocol used by the EPA Region 9 in establishing PRGs (or similar) will be used to establish PALs. If used, this process will be documented in the investigation report. 


\section{A.6.2.2 Total Petroleum Hydrocarbon PALs}

The PAL for TPH is 100 parts per million as listed in NAC 445A.2272 (NAC, 2006c).

\section{A.6.2.3 Radionuclide PALS}

The PALs for radiological contaminants are based on the NCRP Report No. 129 recommended screening limits for construction, commercial, industrial land-use scenarios (NCRP, 1999) scaled to 25-mrem/yr dose constraint (Murphy, 2004) and the generic guidelines for residual concentration of radionuclides in DOE Order 5400.5 (DOE, 1993). These PALs are based on the construction, commercial, and industrial land-use scenario provided in the guidance and are appropriate for the NTS based on future land use scenarios as presented in Section A.2.2.

\section{A.6.3 Decision Rules}

The decision rules applicable to both Decision I and Decision II are:

- If COC contamination is inconsistent with the CSM or extends beyond the spatial boundaries identified in Section A.5.2, then work will be suspended and the investigation strategy will be reconsidered, else the decision will be to continue sampling to define the extent.

The decision rules for Decision I are:

- If the population parameter of any COPC in the Decision I population of interest (defined in Step 4) exceeds the corresponding FAL - then that contaminant is identified as a COC, the contaminated material will be removed, or Decision II samples will be collected until an estimate of the extent of contaminated material has been made.

- If no COC associated with a release from the CAS is detected, then further assessment of the CAS is not required and the corrective action alternative of no further action will be selected. If a COC associated with a release from the CAS is detected, then additional sampling will be conducted to determine the extent of COC contamination. If the extent of the contamination is defined and additional remediation is feasible, then clean close the site by removing the contaminated media until all contamination has been removed. If the extent of contamination has been determined and additional remediation is not feasible, then the contaminated area will be close in place with appropriate use restrictions and the extent of contamination defined. 
- If a waste is present that, if released, has the potential to cause the future contamination of site environmental media at levels above the FALs, then a corrective action will be determined, else no further action will be necessary.

The decision rules for Decision II are:

- If the population parameter (the observed concentration of any COC) in the Decision II population of interest (defined in Step 4) exceeds the corresponding FAL, then additional samples will be collected to complete the Decision II evaluation. If sufficient information is available to define the extent of COC contamination and confirm that closure objectives were met, then further assessment of the CAS is not required. If sufficient information is not available to define the extent of contamination or confirm that closure objectives were met, then additional samples will be collected until the extent is defined.

- If valid analytical results are available for the waste characterization samples defined in Section A.8.0, then the decision will be that sufficient information exists to characterize the IDW for disposal and determine potential remediation waste types, else collect additional waste characterization samples. 


\section{A.7.0 Step 6 - Specify Performance or Acceptance Criteria}

Step 6 of the DQO process defines the decision hypotheses, specifies controls against false rejection and false acceptance decision errors, examines consequences of making incorrect decisions from the test, and places acceptable limits on the likelihood of making decision errors.

\section{A.7.1 Decision Hypotheses}

The baseline condition (i.e., null hypothesis) and alternative condition for Decision I are:

- $\quad$ Baseline condition - A COC is present.

- Alternative condition - A COC is not present.

The baseline condition (i.e., null hypothesis) and alternative condition for Decision II are as follows:

- $\quad$ Baseline condition - The extent of a COC has not been defined.

- Alternative condition - The extent of a COC has been defined.

Decisions and/or criteria have false negative or false positive errors associated with their determination. The impact of these decision errors and the methods that will be used to control these errors are discussed in the following subsections. In general terms, confidence in DQO decisions based on judgmental sampling results will be established qualitatively by:

- The development of and concurrence of CSMs (based on process knowledge) by stakeholder participants during the DQO process;

- Testing the validity of CSMs based on investigation results; and

- $\quad$ Evaluating the quality of the data based on DQI parameters.

\section{A.7.2 False Negative Decision Error}

The false negative decision error would mean deciding that a COC is not present when it actually is (Decision I), or deciding that the extent of a COC has been defined when it has not (Decision II). In both cases the potential consequence is an increased risk to human health and environment. 
In judgmental sampling, the selection of the number and location of samples is based on knowledge of the feature or condition under investigation and on professional judgment (EPA, 2002). Judgmental sampling conclusions about the target population depend upon the validity and accuracy of professional judgment.

The false negative decision error (where consequences are more severe) for judgmental sampling designs is controlled by meeting these criteria:

- For Decision I, having a high degree of confidence that the sample locations selected will identify COCs, if present, anywhere within the CAS. For Decision II, having a high degree of confidence that the sample locations selected will identify the extent of COCs.

- Having a high degree of confidence that analyses conducted will be sufficient to detect any COCs present in the samples.

- Having a high degree of confidence that the dataset is of sufficient quality and completeness.

To satisfy the first criterion, Decision I samples must be collected in areas most likely to be contaminated by COCs (supplemented by random samples where appropriate). Decision II samples must be collected in areas that represent the lateral and vertical extent of contamination (above FALs). The following characteristics must be considered to control decision errors for the first criterion:

- $\quad$ Source and location of release

- Chemical nature and fate properties

- Physical transport pathways and properties

- Hydrologic drivers

These characteristics were considered during the development of the CSMs and selection of sampling locations. The field-screening methods and biasing factors listed in Section A.4.2.1 will be used to further ensure that appropriate sampling locations are selected to meet these criteria. Radiological survey instruments and field-screening equipment will be calibrated and checked in accordance with the manufacturer's instructions and approved procedures. The investigation report will present an assessment on the DQI of representativeness that samples were collected from those locations that best represent the populations of interest as defined in Section A.5.1. 
To satisfy the second criterion, Decision I samples will be analyzed for the chemical and radiological parameters listed in Section 3.2 of the SAFER Plan. Decision II samples will be analyzed for those chemical and radiological parameters that identified unbounded COCs. The DQI of sensitivity will be assessed for all analytical results to ensure that all sample analyses had measurement sensitivities (detection limits) that were less than or equal to the corresponding FALs. If this criterion is not achieved, the affected data will be assessed (for usability and potential impacts on meeting site characterization objectives) in the investigation report.

To satisfy the third criterion, the entire dataset, as well as individual sample results, will be assessed against the DQIs of precision, accuracy, comparability, and completeness as defined in the Industrial Sites QAPP (NNSA/NV, 2002) and in Section 7.2 of the SAFER Plan. The DQIs of precision and accuracy will be used to assess overall analytical method performance as well as to assess the need to potentially “flag” (qualify) individual contaminant results when corresponding QC sample results are not within the established control limits for precision and accuracy. Data qualified as estimated for reasons of precision or accuracy may be considered to meet the constituent performance criteria based on an assessment of the data. The DQI for completeness will be assessed to ensure that all data needs identified in the DQO have been met. The DQI of comparability will be assessed to ensure that all analytical methods used are equivalent to standard EPA methods so that results will be comparable to regulatory action levels that have been established using those procedures. Strict adherence to established procedures and QA/QC protocol protects against false negatives. Site-specific DQIs are discussed in more detail in Section 7.2 of the SAFER Plan.

To provide information for the assessment of the DQIs of precision and accuracy, the following quality control samples will be collected as required by the Industrial Sites QAPP (NNSA/NV, 2002):

- Field duplicates (minimum of 1 per matrix per 20 environmental samples)

- Laboratory QC samples (minimum of 1 per matrix per 20 environmental samples or 1 per CAS per matrix, if less than 20 collected).

\section{A.7.3 False Positive Decision Error}

The false positive decision error would mean deciding that a COC is present when it is not, or a COC is unbounded when it is not, resulting in increased costs for unnecessary sampling and analysis. 
False positive results are typically attributed to laboratory and/or sampling/handling errors that could cause cross contamination. To control against cross contamination, decontamination of sampling equipment will be conducted according to established and approved procedures and only clean sample containers will be used. To determine whether a false positive analytical result may have occurred, the following quality control samples will be collected as required by the Industrial Sites QAPP (NNSA/NV, 2002):

- Trip blanks (1 sample [3 vials] per sample cooler containing VOC environmental samples)

- Equipment blanks (1 per sampling event for each type of decontamination procedure)

- $\quad$ Source blanks (1 per source lot per sampling event)

- Field blanks (minimum of 1 per CAS, additional if field conditions change) 


\section{A.8.0 Step 7 - Develop the Plan for Obtaining Data}

Step 7 of the DQO process selects and documents a design that will yield data that will best achieve performance or acceptance criteria. Judgmental sampling schemes will be implemented to select sample locations and evaluate analytical results for CAU 130. Sections A.8.1 through A.8.2 contain general information about collecting Decision I and Decision II samples under judgmental sampling designs, while the subsequent sections provide CAS-specific sampling activities, including proposed sample locations.

\section{A.8.1 Decision I Sampling}

A judgmental sampling design will be implemented for all of the CAU 130 CASs. Because individual sample results, rather than an average concentration, will be used to compare to FALs at the CASs undergoing judgmental sampling, statistical methods to generate site characteristics will not be used. Adequate representativeness of the entire target population may not be a requirement to developing a sampling design. If good prior information is available on the target site of interest, then the sampling may be designed to collect samples only from areas known to have the highest concentration levels on the target site. If the observed concentrations from these samples are below the action level, then a decision can be made that the site contains safe levels of the contaminant without the samples being truly representative of the entire area (EPA, 2006).

All sample locations will be selected to satisfy the DQI of representativeness in that samples collected from selected locations will best represent the populations of interest as defined in Section A.5.1. To meet this criterion for judgmentally sampled sites, a biased sampling strategy will be used for Decision I samples to target areas with the highest potential for contamination, if it is present anywhere in the CAS. Sample locations will be determined based on process knowledge, previously acquired data, or the field-screening and biasing factors listed in Section A.4.2.1. If biasing factors are present in soils below locations where Decision I samples were removed, additional Decision I soil samples will be collected at depth intervals selected by the Site Supervisor based on biasing factors to a depth where the biasing factors are no longer present. The Site Supervisor has the discretion to modify the judgmental sample locations, but only if the modified locations meet the decision needs and criteria stipulated in this DQO. 


\section{A.8.2 Decision II Sampling}

To meet the DQI of representativeness for Decision II samples (that Decision II sample locations represent the population of interest as defined in Section A.5.1), judgmental sampling locations at each CAS will be selected based on the outer boundary sample locations where COCs were detected, the CSM, and other field-screening and biasing factors listed in Section A.4.2. In general, sample locations will be arranged in a triangular pattern around the Decision I location or area at distances based on site conditions, process knowledge, and biasing factors. If COCs extend beyond the initial step-outs, Decision II samples will be collected from incremental step-outs. Initial step-outs will be at least as deep as the vertical extent of contamination defined at the Decision I location and the depth of the incremental step-outs will be based on the deepest contamination observed at all locations. A clean sample (i.e., COCs less than FALs) collected from each step-out direction (lateral or vertical) will define extent of contamination in that direction. The number, location, and spacing of step-outs may be modified by the Site Supervisor, as warranted by site conditions as long as the modifications meet the requirements of the DQOs.

\section{A.8.3 Corrective Action Site 01-02-01, Underground Storage Tank}

The judgmental sample locations at CAS 01-02-01 have been selected based on the 4-in. steel pipe at ground surface with a lid that reads "GAS,” and the slightly disturbed soils surrounding the pipe.

Figure A.8-1 shows the proposed sample strategy for CAS 01-02-01. A Decision I sample will be collected at the surface contact beside the exposed pipe. A backhoe will excavate within the area of the UST to determine whether a UST is present. If a UST is present, then the following additional sampling will be conducted:

- The contents, if any, of each phase inside the UST will be sampled.

- $\quad$ One soil sample will be collected under each end of the base of the UST.

- One soil sample will be collected from below the inlet, and one soil sample will be collected from below the outlet piping of the tank, if these features are present.

- Additional Decision I samples may be collected based on biasing factors during excavation.

- The UST will be closed in accordance with NAC Section 459.9972 (NAC, 2007). 


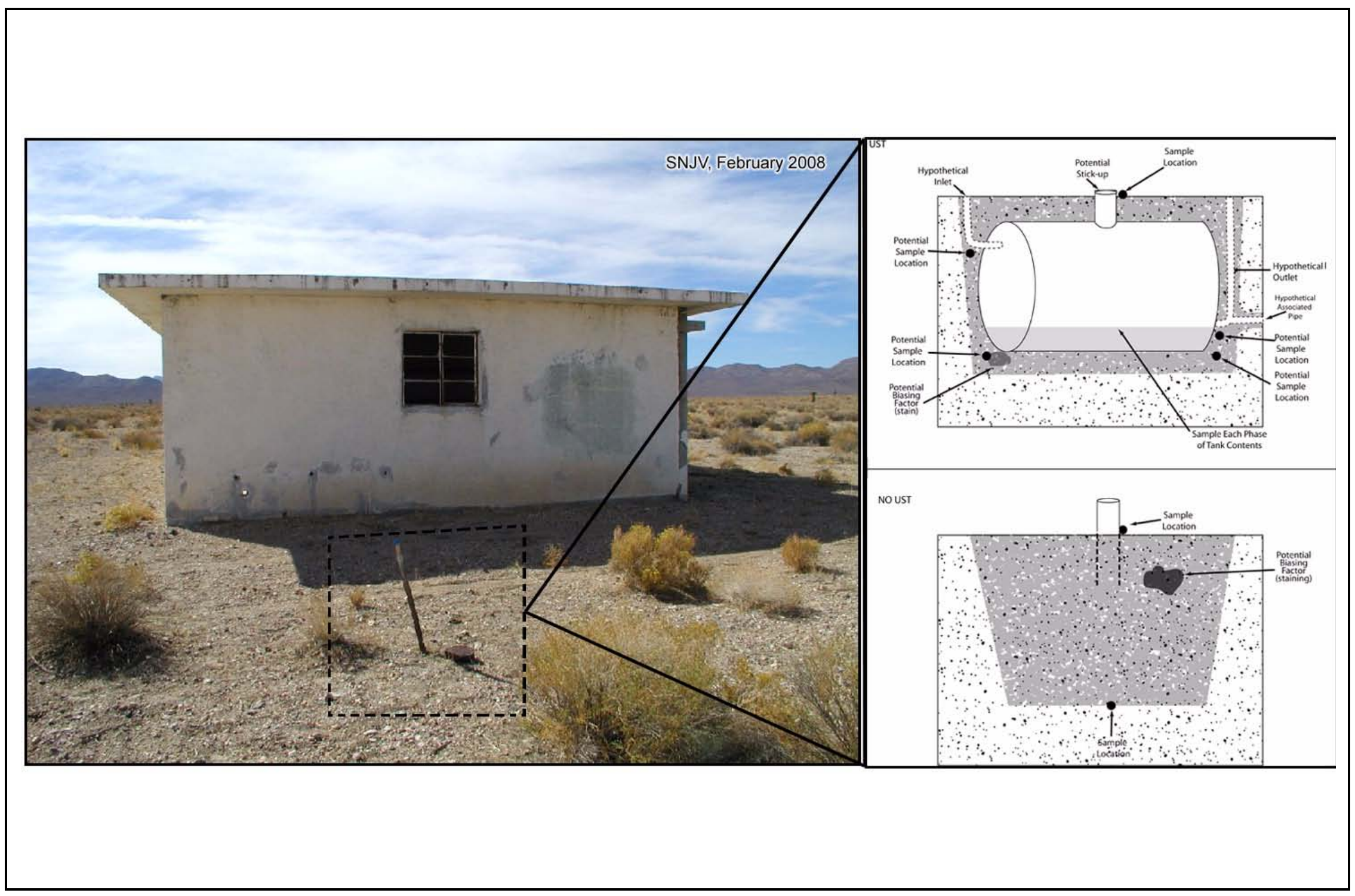

Figure A.8-1

Proposed Sample Strategy at CAS 01-02-01 
- The UST contents, if any, will be disposed of in accordance with Section 6.0 of the SAFER Plan.

If no UST is present, the excavated material will be observed for biasing factors, such as staining to the undisturbed native soil interface. If no biasing factors are observed, then the following additional sampling will be conducted:

- One soil sample will be collected at the undisturbed native soil interface.

- If the undisturbed native soil interface cannot be determined, one soil sample will be collected at approximately $4 \mathrm{ft}$ bgs, and one soil sample will be collected at approximately $6 \mathrm{ft}$ bgs.

Samples will be submitted for analysis in accordance with the analytical program listed in Table 3-1.

\section{A.8.4 Corrective Action Site 07-02-01, Underground Storage Tanks}

The judgmental sample locations at CAS 07-02-01 have been selected based on Station 7-235, the lead brick, and the results of the geophysical survey.

Figure A.8-2 shows the proposed sample strategy for CAS 07-02-01. A backhoe will excavate within the areas of the potential USTs. If USTs are present, then the following additional sampling will be conducted:

- The contents, if any, of each phase inside the UST will be sampled.

- One soil sample will be collected under each end of the base of the UST.

- One soil sample will be collected from below the inlet, and one soil sample will be collected from below the outlet piping of the tank if these features are present.

- Additional Decision I samples may be collected based on biasing factors during excavation.

- The UST will be closed in accordance with NAC Section 459.9972 (NAC, 2007).

- The UST contents, if any, will be disposed of in accordance with Section 6.0 of the SAFER Plan. 


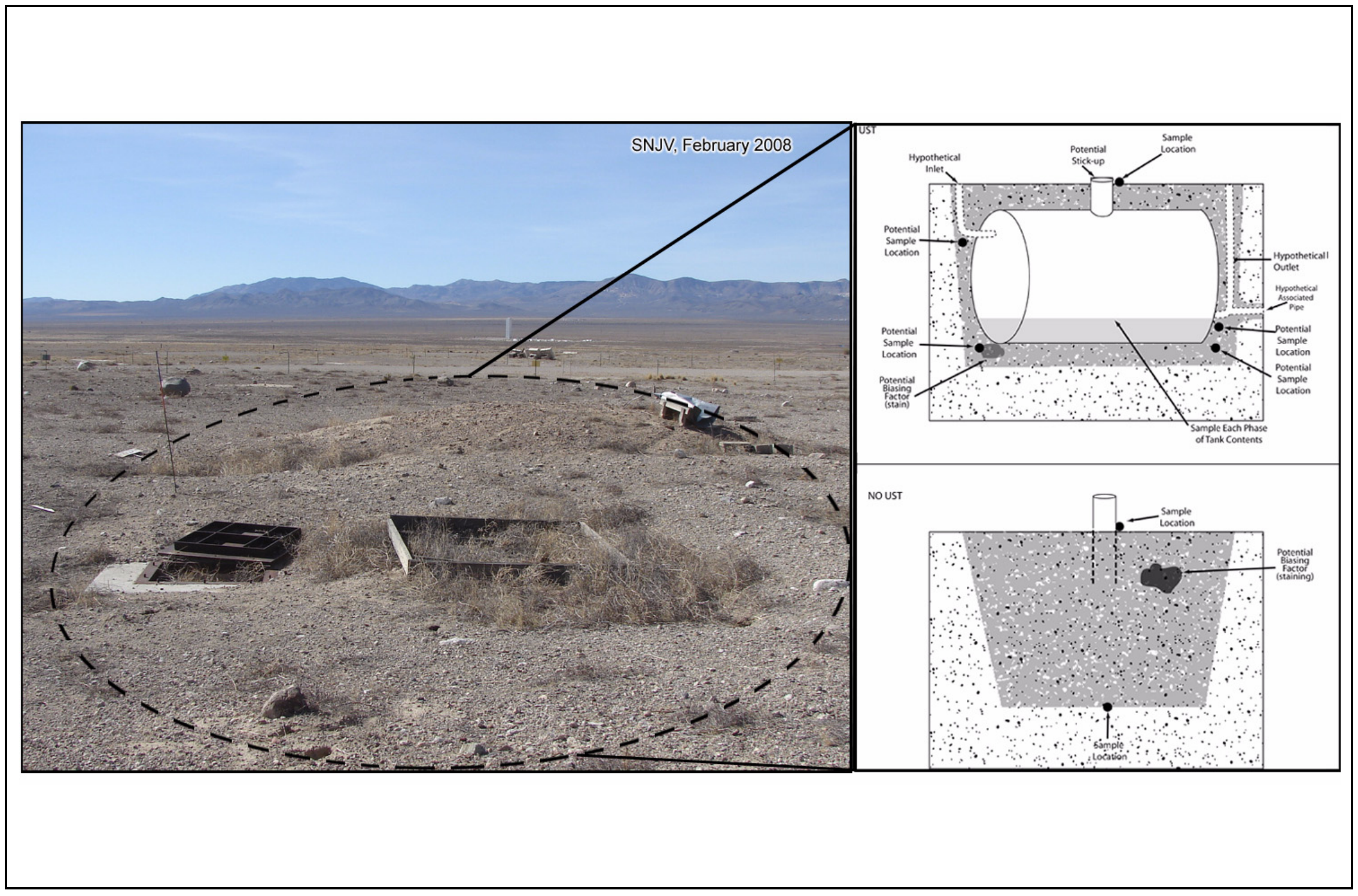

Figure A.8-2

Proposed Sample Strategy at CAS 07-02-01 
If no UST is present, the excavated material will be observed for biasing factors, such as staining to the undisturbed native soil interface. If no biasing factors are observed, then the following additional sampling will be conducted:

- One soil sample will be collected at the undisturbed native soil interface.

- If the undisturbed native soil interface cannot be determined, one soil sample will be collected at approximately $4 \mathrm{ft}$ bgs, and one soil sample will be collected at approximately $6 \mathrm{ft}$ bgs.

Should the excavation reveal a different type of structure (i.e., bunker[s]), the structure(s) will be excavated to the base to investigate a potential for a release. If the structure type is not addressed by the CSM, a revised approach will be developed and approved by the stakeholders before proceeding. Samples will be collected based on biasing factors during the excavation.

Any lead bricks will be removed (and associated soil), and a soil sample will be collected from under the center of the excavation.

Samples will be submitted for analysis in accordance with the analytical program listed in Table 3-1.

\section{A.8.5 Corrective Action Site 10-02-01, Underground Storage Tank}

The judgmental sample locations at CAS 10-02-01 have been selected based on the three 3-in. pipes above ground surface, the concrete pad adjacent to the pipes, and the slightly disturbed soils surrounding the pipes.

Figure A.8-3 shows the proposed sample strategy for CAS 10-02-01. Decision I soil samples will be collected at the surface next to each exposed pipe. One surface soil sample will be collected at the middle edge of each side of the concrete pad. A backhoe will excavate within the area of the UST to determine whether a UST is present. If a UST is present, then the following additional sampling will be conducted:

- The contents, if any, of each phase inside the UST will be sampled.

- One soil sample will be collected under each end of the base of the UST.

- One soil sample will be collected from below the inlet, and one soil sample will be collected from below the outlet piping of the tank if these features are present. 


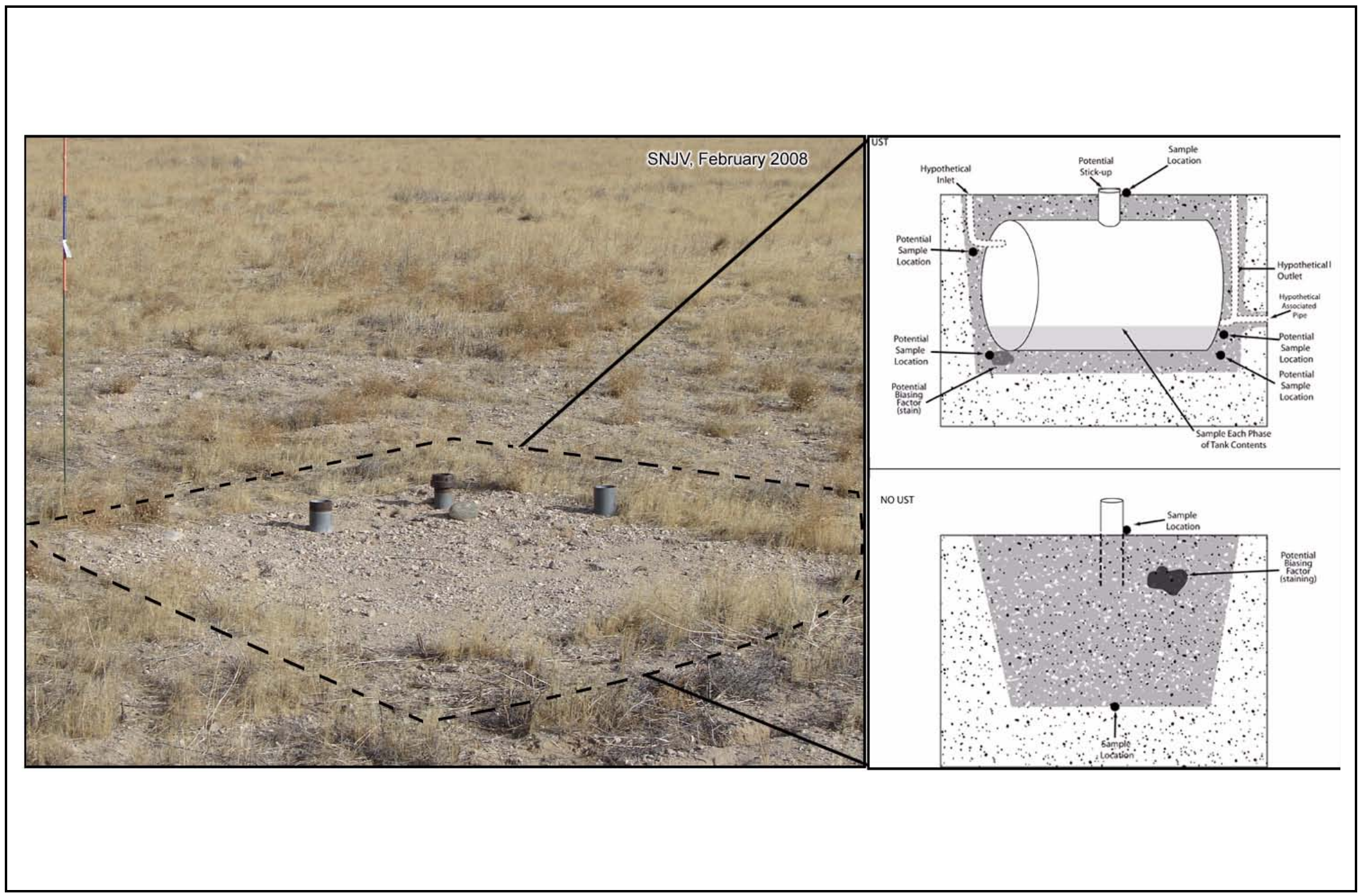

Figure A.8-3

Proposed Sample Strategy at CAS 10-02-01 
- Additional Decision I samples may be collected based on biasing factors during excavation.

- The UST will be closed in accordance with NAC Section 459.9972 (NAC, 2007).

- The UST contents, if any, will be disposed of in accordance with Section 6.0 of the SAFER Plan.

If no UST is present, the excavated material will be observed for biasing factors, such as staining to the undisturbed native soil interface. If no biasing factors are observed, then the following additional sampling will be conducted:

- One soil sample will be collected at the undisturbed native soil interface.

- If the undisturbed native soil interface cannot be determined, one soil sample will be collected at approximately $4 \mathrm{ft}$ bgs, and one soil sample will be collected at approximately $6 \mathrm{ft}$ bgs.

Samples will be submitted for analysis in accordance with the analytical program listed in Table 3-1.

\section{A.8.6 Corrective Action Site 20-02-03, Underground Storage Tank}

The judgmental sample locations at CAS 20-02-03 have been selected based on the planned engineering drawings and the geophysical survey.

Figure A.8-4 shows the proposed sample strategy for CAS 20-02-03. There are two areas that will be excavated: one where the engineered planned drawing depict a UST and one area where the geophysical survey depicts an anomaly. There are no surface features associated with the UST; therefore, no surface samples will be collected. The areas of the UST and anomaly will be excavated. If a UST is present, then the following sampling will be conducted:

- The contents, if any, of each phase inside the UST will be sampled.

- One soil sample will be collected under each end of the base of the UST.

- One soil sample will be collected from below the inlet, and one soil sample will be collected from below the outlet piping of the tank if these features are present.

- Additional Decision I samples may be collected based on biasing factors during excavation. 


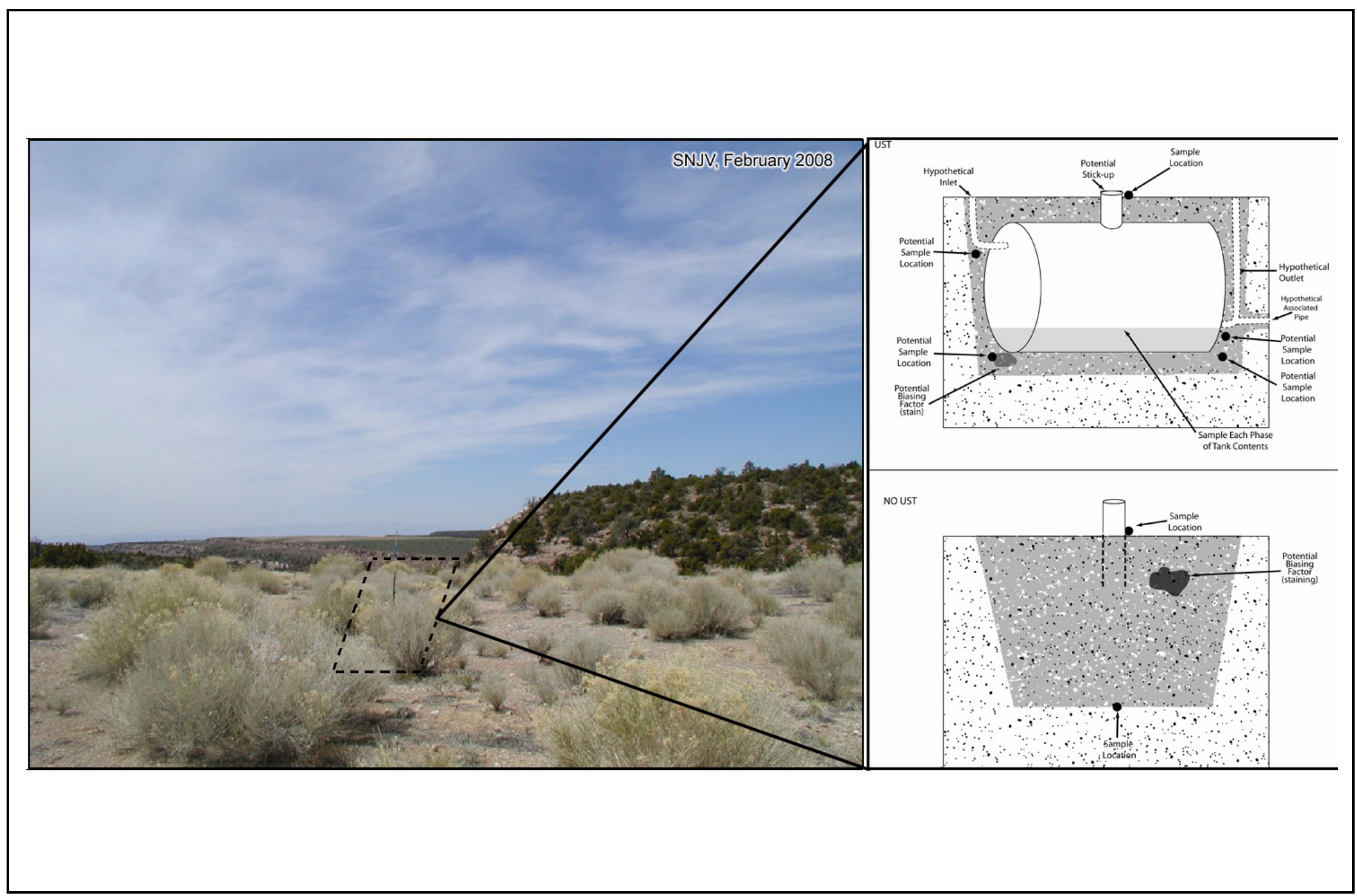

Figure A.8-4

Proposed Sample Strategy at CAS 20-02-03 
- The UST will be closed in accordance with NAC Section 459.9972 (NAC, 2007).

- The UST contents, if any, will be disposed of in accordance with Section 6.0 of the SAFER Plan.

If no UST is present, the excavated material will be observed for biasing factors, such as staining to the undisturbed native soil interface. If no biasing factors are observed, then the following sampling will be conducted :

- One soil sample will be collected at the undisturbed native soil interface.

- If the undisturbed native soil interface cannot be determined, one soil sample will be collected at approximately $4 \mathrm{ft}$ bgs, and one soil sample will be collected at approximately $6 \mathrm{ft}$ bgs.

Samples will be submitted for analysis in accordance with the analytical program listed in Table 3-1.

\section{A.8.7 Corrective Action Site 20-99-05, Tar Residue}

The judgmental sample locations at CAS 20-99-05 have been selected based on the tar on the ground surface that covers an approximate 40 -by-30-ft area. The tar is dark black, hardened, cracked, and brittle material that has a hydrocarbon odor. The patches of tar range from approximately 0.5 to 2.0 in. thick.

Figure A.8-5 shows the proposed sample strategy for CAS 20-02-03:

- The tar will be sampled at two locations to determine whether it is PSM and for waste characterization purposes. The locations will be selected at the two larger areas of accumulated tar, if no other biasing factors are identified.

- Two surface soil samples will be collected beneath two of the larger areas of accumulated tar. Samples will be submitted for analysis in accordance with the analytical program listed in Table 3-1.

\section{A.8.8 Corrective Action Site 22-02-02, Buried UST Piping}

The judgmental sample locations at CAS 22-02-02 have been selected based on site photographs, the association to CAS 22-19-06, Buried Waste Disposal Site, where former USTs and aboveground storage tanks were located, and the geophysical survey. 

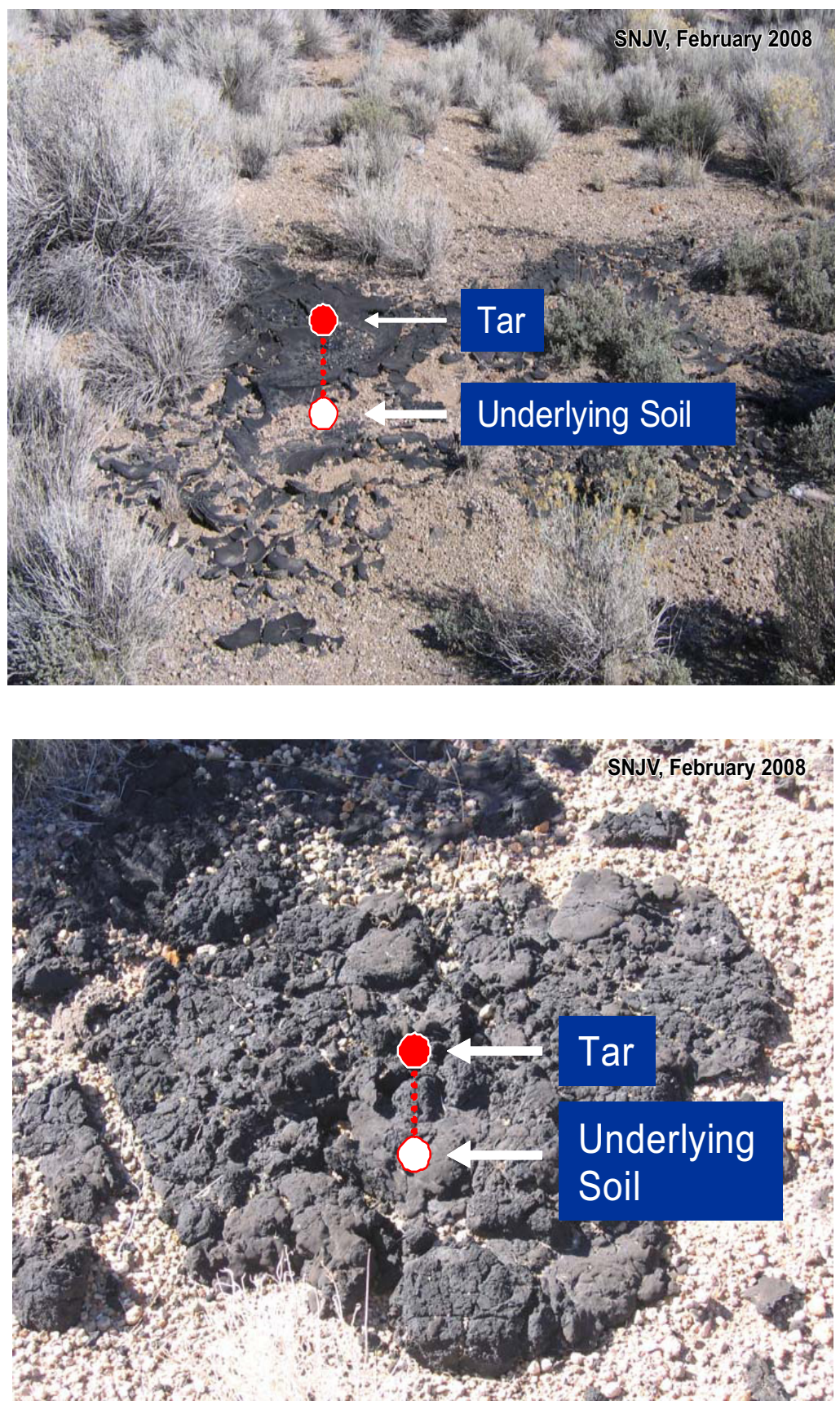

Figure A.8-5

Proposed Sample Strategy at CAS 20-99-05 
Figure A.8-6 shows the proposed sample strategy for CAS 22-02-02.

- One surface soil sample will be collected inside the concrete foundation beneath the pipe opening to include the stained soils.

- One soil sample will be collected below the pipe where it connects to the concrete foundation outer wall.

- One soil sample will be collected below the pipe where it connects to the concrete island.

The buried UST piping will be fully excavated and removed. Soil samples will be collected based on biasing factors observed during excavation.

Samples will be submitted for analysis in accordance with the analytical program listed in Table 3-1.

\section{A.8.9 Corrective Action Site 23-02-07, Underground Storage Tank}

The judgmental sample locations at CAS 23-02-07 have been selected based on the report “Notification to Nevada Division of Environmental Protection (NDEP) of Tank Closures and Upgrades” (Haworth, 1990) and the geophysical survey.

Figure A.8-7 shows the proposed sample strategy for CAS 23-02-07. There are no surface features associated with the UST; therefore, no surface samples will be collected. A backhoe will excavate within the area of the UST to determine whether a UST is present. If a UST is present, and the UST has not been filled with inert material (i.e., grout), then:

- $\quad$ The contents, if any, of each phase inside the UST will be sampled.

- One soil sample will be collected under each end of the base of the UST.

- One soil sample will be collected from below the inlet, and one soil sample will be collected from below the outlet piping of the tank if these features are present.

- Additional Decision I samples may be collected based on biasing factors during excavation.

- $\quad$ The UST will be closed in accordance with NAC Section 459.9972 (NAC, 2007).

- The UST and contents, if any, will be disposed of in accordance with Section 6.0 of the SAFER Plan. 


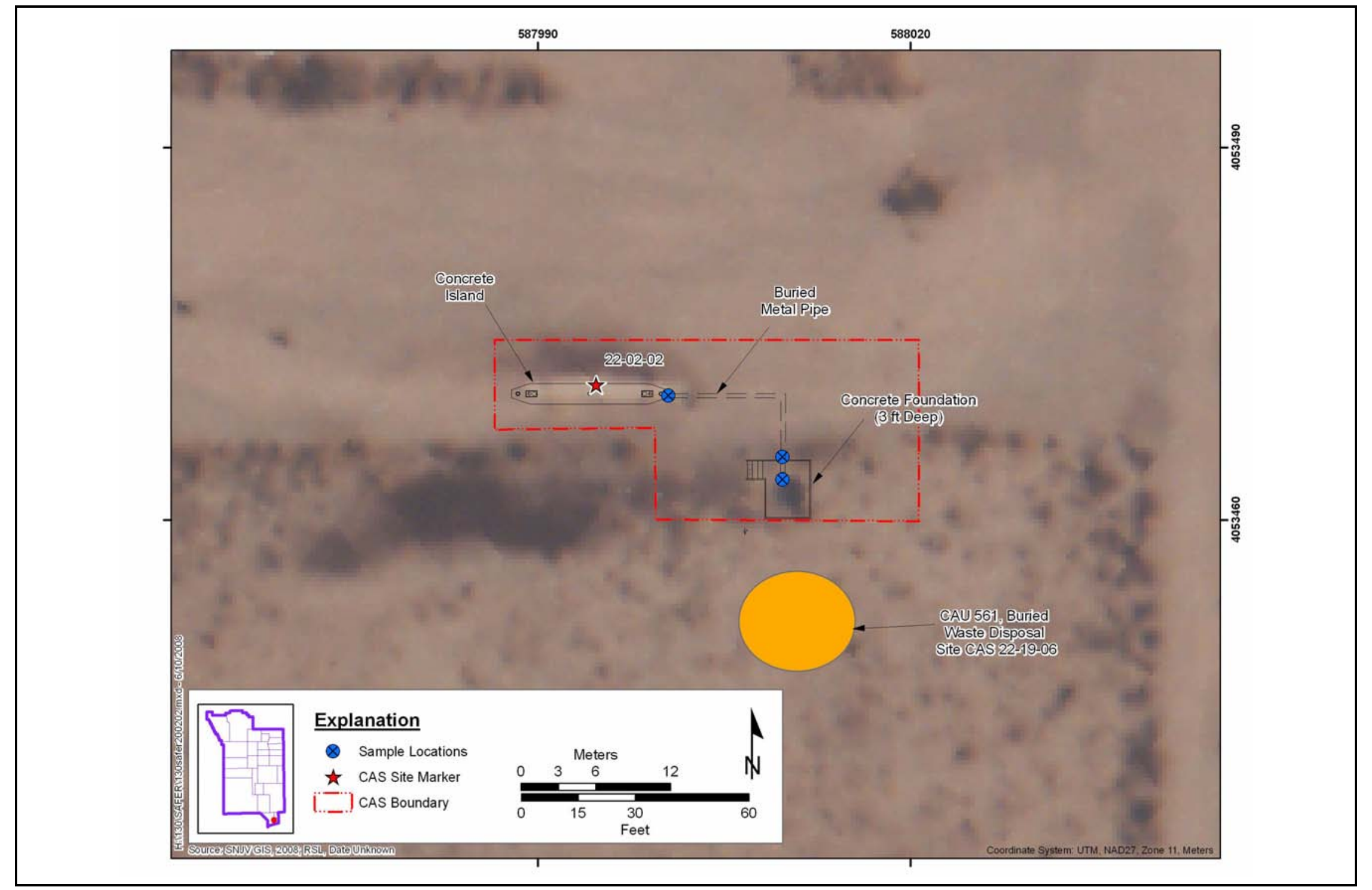

Figure A.8-6

Proposed Sample Strategy at CAS 22-02-02 


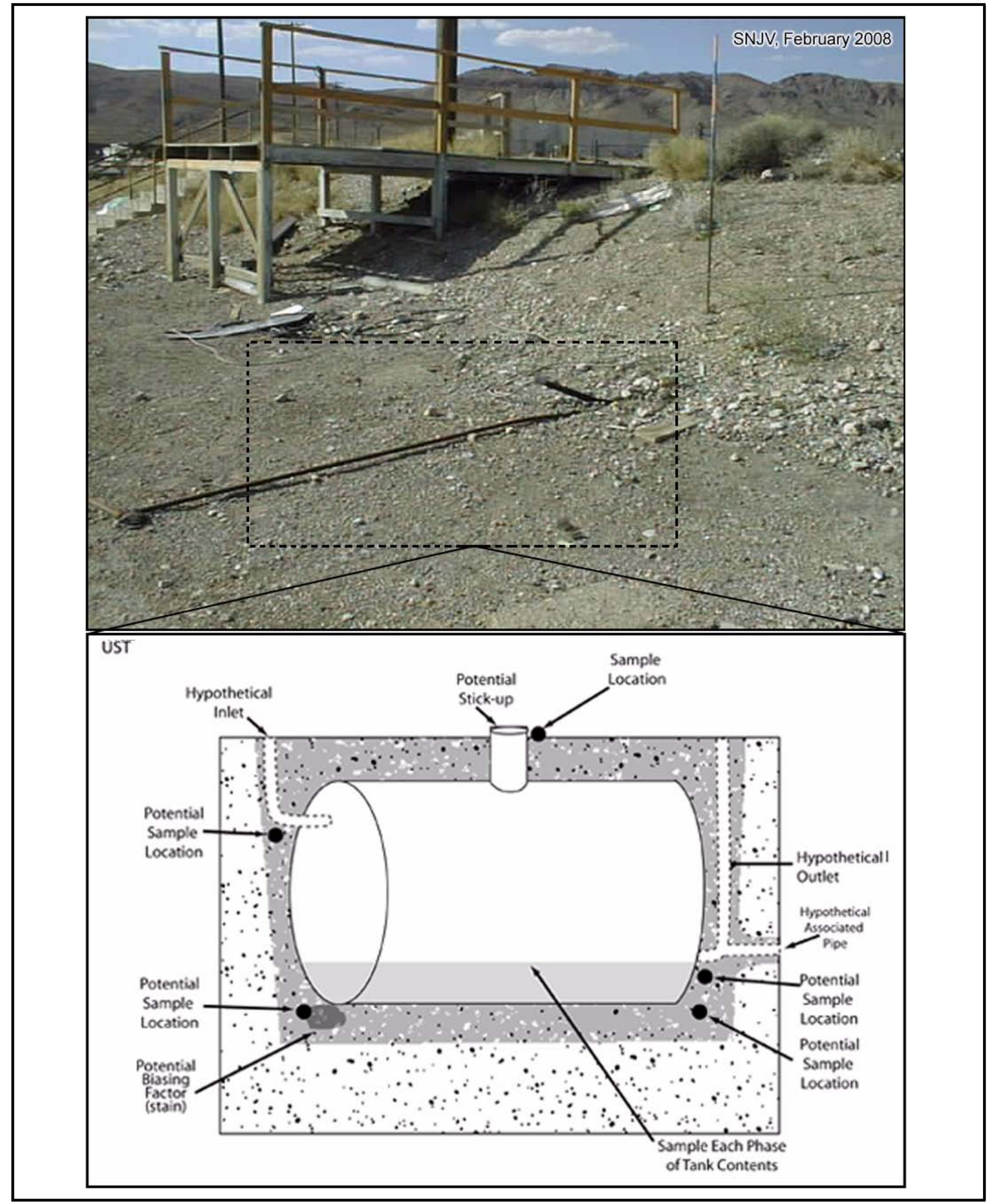

Figure A.8-7

Proposed Sample Strategy at CAS 23-02-07 
If the UST is in place and filled with inert material (i.e., grout), then:

- One soil sample will be collected under each end of the base of the UST.

- Additional Decision I samples may be collected based on biasing factors.

If no UST is present, the excavated material will be observed for biasing factors, such as staining to the undisturbed native soil interface. If no biasing factors are observed, then:

- One soil sample will be collected at the undisturbed native soil interface.

- If the undisturbed native soil interface cannot be determined, one soil sample will be collected at approximately $4 \mathrm{ft}$ bgs, and one soil sample will be collected at approximately $6 \mathrm{ft}$ bgs.

Samples will be submitted for analysis in accordance with the analytical program listed in Table 3-1. 


\section{A.9.0 References}

ARL/SORD, see Air Resources Laboratory/Special Operations and Research Division.

ASTM, see American Society for Testing and Materials.

Air Resources Laboratory/Special Operations and Research Division. 2006. Air Resources

Laboratory/Special Operations and Research Division website. As accessed at

http://www.sord.nv.doe.gov/home_climate.htm on 3 March 2008.

American Society for Testing and Materials. 1995. Standard Guide for Risk-Based Corrective Action Applied at Petroleum Release Sites, ASTM E 1739-95 (Reapproved 2002). Philadelphia, PA.

DOE, see U.S. Department of Energy.

DOE/NV, see U.S. Department of Energy, Nevada Operations Office.

EPA, see U.S. Environmental Protection Agency.

Haworth, O. Bechtel Nevada. 1990. Letter entitled "Notification to Nevada Division of Environmental Protection (NDEP) of Tank Closures and Upgrades,” 17 December. Las Vegas, NV.

Moore, J., Science Applications International Corporation. 1999. Memorandum to M Todd (SAIC) entitled, “Background Concentrations for NTS and TTR Soil Samples,” 3 February. Las Vegas, NV: IT Corporation.

Murphy, T., Bureau of Federal Facilities. 2004. Letter to R. Bangerter (NNSA/NSO) entitled, "Review of Industrial Sites Project Document Guidance for Calculating Industrial Sites Project Remediation Goals for Radionuclides in Soil Using the Residual Radiation (RESRAD) Computer Code.” 19 November. Las Vegas, NV.

NAC, see Nevada Administrative Code.

NBMG, see Nevada Bureau of Mines and Geology.

NCRP, see National Council on Radiation Protection and Measurements.

NNSA/NSO, see U.S. Department of Energy, National Nuclear Security Administration Nevada Site Office.

NNSA/NV, see U.S. Department of Energy, National Nuclear Security Administration Nevada Operations Office. 
National Council on Radiation Protection and Measurements. 1999. Recommended Screening Limits for Contaminated Surface Soil and Review of Factors Relevant to Site-Specific Studies, NCRP Report No. 129. Bethesda, MD.

Nevada Administrative Code. 2006a. NAC 445A.227, “Contamination of Soil: Order by Director for Corrective Action; Factors To Be Considered in Determining Whether Corrective Action Required.” Carson City, NV. As accessed at http://www.leg.state.nv.us/nac on 3 March 2008.

Nevada Administrative Code. 2006b. NAC 445A.22705, "Contamination of Soil: Evaluation of Site by Owner or Operator; Review of Evaluation by Division.” Carson City, NV. As accessed at http://www.leg.state.nv.us/nac on 3 March 2008.

Nevada Administrative Code. 2006c. NAC 445A.2272, "Contamination of Soil: Establishment of Action Levels.” Carson City, NV. As accessed at http://www.leg.state.nv.us/nac on 3 March 2008.

Nevada Administrative Code. 2007. NAC 459.9972, “Assessment Required before Closure of Tank; Removal of Tank from Ground.” Carson City, NV. As accessed at http://www.leg.state.nv.us/nac on 3 March 2008.

Nevada Bureau of Mines and Geology. 1998. Mineral and Energy Resource Assessment of the Nellis Air Force Range, Open-File Report 98-1. Reno, NV.

RSL, see Remote Sensing Laboratory.

Remote Sensing Laboratory. Date Unknown. Aerial photograph “8450.” Las Vegas, NV.

SNJV GIS, see Stoller-Navarro Joint Venture Geographic Information Systems.

Stoller-Navarro Joint Venture Geographic Information Systems. 2008. ESRI ArcGIS Software.

U.S. Department of Energy. 1993. Radiation Protection of the Public and the Environment, DOE Order 5400.5, Change 2. Washington, DC: U.S. Government Printing Office.

U.S. Department of Energy, National Nuclear Security Administration Nevada Operations Office. 2002. Industrial Sites Quality Assurance Project Plan, Nevada Test Site, Nevada, Rev. 3, DOE/NV--372. Las Vegas, NV.

U.S. Department of Energy, National Nuclear Security Administration Nevada Site Office. 2006. Industrial Sites Project Establishment of Final Action Levels, DOE/NV--1107, Rev. 0. Las Vegas, NV.

U.S. Department of Energy, Nevada Operations Office. 1996. Final Environmental Impact Statement for the Nevada Test Site and Off-Site Locations in the State of Nevada, DOE/EIS0243. Las Vegas, NV. 
U.S. Department of Energy, Nevada Operations Office. 1998. Nevada Test Site Resource Management Plan, DOE/NV-518. Las Vegas, NV.

U.S. Environmental Protection Agency. 2002. Guidance for Quality Assurance Project Plans, EPA QA/G5. Washington, DC.

U.S. Environmental Protection Agency. 2004. Region 9 Preliminary Remediation Goals (PRGs). As accessed at http://www.epa.gov/region09/waste/sfund/prg/index.htm on 3 March 2008. Prepared by S.J. Smucker. San Francisco, CA.

U.S. Environmental Protection Agency. 2006. EPA Guidance on Systematic Planning Using the Data Quality Objectives Process, EPA QA/G-4. Washington, DC.

Winograd, I.J., and W. Thordarson. 1975. Hydrology and Hydrochemical Framework, South-Central Great Basin, Nevada-California, with Special Reference to the Nevada Test Site, USGS Professional Paper 712-C. Denver, CO. 


\section{Appendix B}

Closure Certification 


\section{B.1.0 Closure Certification}

This section does not apply to CAU 130 . 


\section{Appendix C}

\section{As-Built Documentation}




\section{C.1.0 As-Built Documentation}

This section does not apply to CAU 130 . 


\section{Appendix D}

\section{Confirmation Sampling Test Results}




\section{D.1.0 Introduction}

This appendix presents the CAI activities and analytical results for CAU 130. Corrective Action Unit 130 is located in Areas 1, 7, 10, 20, 22, and 23 of the NTS (Figure D.1-1), and is comprised of the seven CASs listed below:

- 01-02-01, Underground Storage Tank

- 07-02-01, Underground Storage Tanks

- 10-02-01, Underground Storage Tank

- 20-02-03, Underground Storage Tank

- 20-99-05, Tar Residue

- 22-02-02, Buried UST Piping

- 23-02-07, Underground Storage Tank

Corrective Action Site 01-02-01, Underground Storage Tank, is located within the Apple II Test District and consists of natural gas underground piping installations between Buildings 1-31.1e1 and 1-31.4b1. This installation includes a ground-level surface pipe with a cap that reads “GAS,” "H”-configured assemblies of 6-in. pipe, and service pipes that may have connected to residential-type pressure regulators and gas appliances in the buildings. There was no UST discovered during the investigation.

Corrective Action Site 07-02-01, Underground Storage Tanks, is located in Area 7 west of the T7c atmospheric site. This CAS is believed to be associated with instrumentation for atmospheric testing. Excavation revealed five concrete pads along with Station 7-235. There were no USTs identified during the investigation.

Corrective Action Site 10-02-01, Underground Storage Tank, is located in Area 10 near the U10x crater from the Ward underground nuclear test. The site had three pipes extending above the ground surface. Excavation revealed the three pipes were part of a concrete lid that covered a battery vault containing 118 dry cell batteries. There was no UST identified during the investigation.

Corrective Action Site 20-02-03, Underground Storage Tank, is located in Area 20 within the U20az post-test cellar site associated with the Barnwell underground test nuclear test. The UST was believed to have been a gas sampling tank used during post-test drillback operations. Two locations 


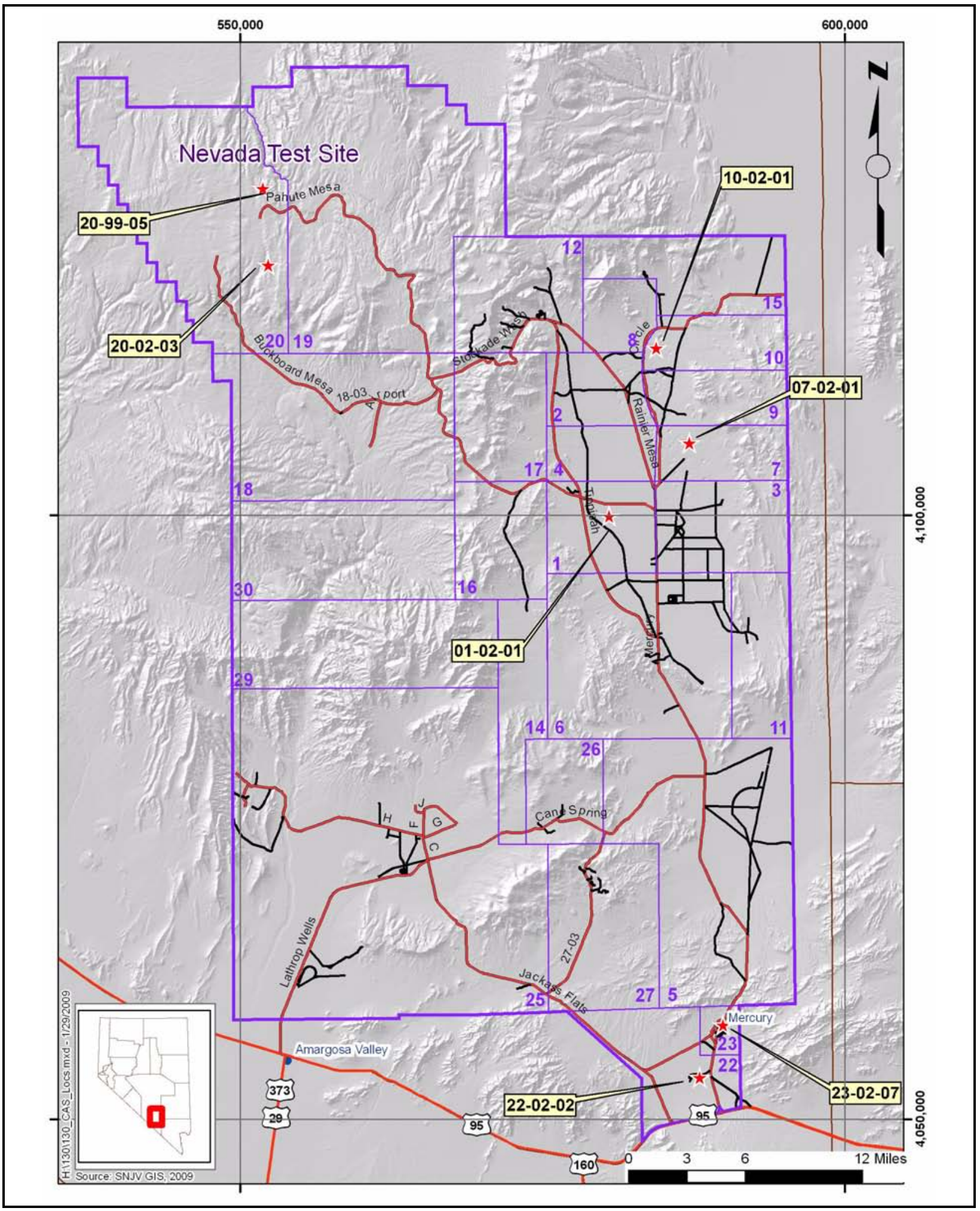

Figure D.1-1

CAU 130 CAS Location Map 
initially identified as potential locations were excavated: the planned location according to the engineering drawings, and a geophysical anomaly. Neither location revealed a UST.

Corrective Action Site 20-99-05, Tar Residue, is located in Area 20 within the U20z boundary of the Kasseri underground nuclear test. The tar residue was sampled for waste management and environmental protection. The data show no COCs; however, the residue was picked up and disposed of as a BMP.

Corrective Action Site 22-02-02, Buried UST Piping, is located in Area 22 at the former Camp Desert Rock. The former gas station included a concrete island that may have been the fill station; a concrete foundation (Building T-951), which may have been the flow control room; and the piping connecting the features. The piping and associated lines were excavated and disposed as required.

Corrective Action Site 23-02-07, Underground Storage Tank, is located in Area 23 at a former service station adjacent to Building 23-119. The tank is reported to have been used to store waste oil. The UST was identified as tank 23-119-1 and closed in place in 1990. Excavation revealed the UST was filled with grout and surrounded by clean fill.

Additional information regarding the history of each site, planning, and the scope of the investigation is presented in the CAU 130 SAFER Plan (NNSA/NSO, 2008).

\section{D.1.1 Project Objectives}

The primary objective of the investigation was to provide sufficient information to validate the assumptions used to select the corrective actions and to verify that closure objectives were met for each CAS in CAU 130. This objective was achieved by determining the presence of COCs and the vertical and lateral extent of the COCs, if present.

The selection of soil and/or waste characterization sample locations was based on site conditions, and the strategy developed during the DQO process as presented in the CAU 130 SAFER Plan (Appendix A). The sampling strategy primarily involved biased sample locations. 


\section{D.1.2 Contents}

This appendix contains information and data in sufficient detail to justify that no further corrective action is required at CAU 130. The contents of this appendix are as follows:

- Section D.1.0 describes the investigation background, objectives, and content.

- Section D.2.0 provides an investigation overview.

- Sections D.3.0 through D.9.0 provides CAS-specific information regarding the field activities, sampling methods, and laboratory analytical results from investigation sampling.

- Section D.10.0 summarizes waste management activities.

- Section D.11.0 discusses the QA and QC procedures followed and results of the QA/QC activities.

- Section D.12.0 is a summary of the investigation results.

- Section D.13.0 lists the cited references.

The complete field documentation and laboratory data, including field activity daily logs, sample collection logs (SCLs), analysis request/chain-of-custody forms, soil sample descriptions, laboratory certificates of analyses, analytical results, and surveillance results are retained in project files as hard copy files or electronic media. 


\section{D.2.0 Investigation Overview}

Field investigation and sampling activities for the CAU 130 CAI were conducted from August 4 through September 30, 2008. Table D.2-1 lists the CAI activities that were conducted at each of the CASs.

Table D.2-1

CAI Activities Conducted at Each CAS To Meet SAFER Plan Requirements for CAU 130

\begin{tabular}{|c|c|c|c|c|c|c|c|}
\hline \multirow[b]{2}{*}{ CAl Activities } & \multicolumn{7}{|c|}{ CAS } \\
\hline & 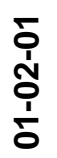 & 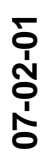 & $\begin{array}{l}\text { 어 } \\
\text { Ǹ } \\
\text { ò } \\
\text { ò }\end{array}$ & 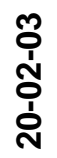 & $\begin{array}{l}\text { 오 } \\
\text { ò } \\
\text { ờ } \\
\text { ㅇํ }\end{array}$ & 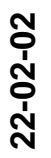 & $\begin{array}{l}\text { ò } \\
\text { Ṅ } \\
\text { Oे } \\
\text { Ṅ }\end{array}$ \\
\hline Inspected and verified the CAS components identified in the SAFER Plan. & $\mathrm{X}$ & $\mathrm{X}$ & $\mathrm{X}$ & $\mathrm{X}$ & $\mathrm{X}$ & $\mathrm{X}$ & $\mathrm{X}$ \\
\hline Performed site walkovers to identify biased sampling locations. & $\mathrm{X}$ & $\mathrm{X}$ & $\mathrm{X}$ & $\mathrm{X}$ & $\mathrm{x}$ & $\mathrm{X}$ & $\mathrm{X}$ \\
\hline Conducted surface radiological surveys. & $\mathrm{X}$ & $\mathrm{X}$ & $\mathrm{X}$ & $\mathrm{X}$ & $\mathrm{X}$ & $\mathrm{X}$ & -- \\
\hline Performed site transects/walkover surveys. & $\mathrm{X}$ & $\mathrm{x}$ & $\mathrm{X}$ & $x$ & -- & -- & -- \\
\hline Conducted geophysical/utility surveys. & $x$ & $\mathrm{X}$ & $\mathrm{X}$ & $\mathrm{x}$ & -- & $\mathrm{X}$ & $x$ \\
\hline Performed video investigation & -- & $\mathrm{x}$ & -- & -- & -- & -- & -- \\
\hline Collected biased soil samples. & $x$ & $x$ & $\mathrm{X}$ & $\mathrm{x}$ & $x$ & $\mathrm{X}$ & $x$ \\
\hline Field screened samples for alpha and beta/gamma radiation. & $\mathrm{X}$ & $\mathrm{X}$ & $\mathrm{X}$ & $\mathrm{X}$ & $\mathrm{X}$ & $\mathrm{X}$ & $\mathrm{X}$ \\
\hline Collected samples for waste characterization. & -- & $\mathrm{X}$ & $\mathrm{X}$ & -- & $x$ & -- & $\mathrm{X}$ \\
\hline Collected swipe samples for removable activity determination. & -- & $\mathrm{X}$ & $\mathrm{X}$ & -- & $\mathrm{x}$ & $\mathrm{x}$ & -- \\
\hline Submitted select samples for offsite laboratory analysis. & $x$ & $\mathrm{X}$ & $\mathrm{X}$ & $\mathrm{X}$ & $x$ & $x$ & X \\
\hline Collected GPS coordinates for sample locations and points of interest. & $X$ & $\mathrm{X}$ & $\mathrm{X}$ & $\mathrm{X}$ & $\mathrm{X}$ & $\mathrm{x}$ & $\mathrm{X}$ \\
\hline
\end{tabular}

-- = Not applicable

The investigation and sampling program was conducted in accordance with the requirements set forth in the CAU 130 SAFER Plan (NNSA/NSO, 2008). Field activities were performed in compliance with safety documents that are consistent with the DOE Integrated Safety Management System. Samples were collected and documented following approved protocols and procedures. Quality control samples (e.g., field blanks, equipment rinsate blanks, trip blanks, and duplicate samples) were collected as required by the Industrial Sites QAPP (NNSA/NV, 2002) and the CAU 130 SAFER 
Plan (NNSA/NSO, 2008). During field activities, waste minimization practices were followed according to approved procedures, including segregation of waste by waste stream.

Weather conditions at the site varied to include sun (high temperatures), intermittent cloudiness, and light to strong winds.

The CASs were investigated by conducting radiological surface screening and surveys, and sampling potential contaminant sources in the surface and subsurface soils. Surface soil samples were collected by hand excavation. Subsurface soil samples were collected using a backhoe. The soil samples were field screened at specific locations for VOCs, alpha and beta/gamma radiation, and gamma-emitting radionuclides. The results were compared against screening levels to guide in the CAS-specific investigations. Samples of various media (e.g., liquid, tar residue) were collected to support both environmental and waste characterization using disposable scoops, and a peristaltic pump with silicone tubing. Solid, liquid, and sediment waste samples were field screened to guide in the selection of the samples shipped to offsite laboratories for analysis. Field screening was also for health and safety controls and to meet transportation requirements.

Corrective Action Unit 130 Decision I sampling locations were accessible, and sampling activities at planned locations were not restricted. Because there were no COCs identified during the investigation, Decision II sampling was not required.

Sections D.2.1 through D.2.4 provide the investigation methodology and laboratory analytical information.

\section{D.2.1 Sample Locations}

Investigation locations selected for sampling were based on interpretation of existing engineering drawings, aerial and land photographs, interviews with former and current site employees, information obtained during site visits, and site conditions as provided in the CAU 130 SAFER Plan (NNSA/NSO, 2008). Sampling points for each site were selected based on the approach provided in the SAFER Plan. The planned biased sample locations are discussed in the text and represented on figures in the SAFER Plan. Actual environmental sample locations are shown on the figures included in Sections D.3.0 through D.9.0. Some locations were modified slightly from planned positions due 
to field conditions and observations. Sample locations were staked where appropriate and labeled. The majority of sample locations were surveyed with a GPS instrument. A Trimble GeoXT 2005 series GPS instrument was used for determining the sample location coordinates as well as CAS points of interest.

\section{D.2.2 Investigation Activities}

The investigation activities performed at CAU 130 were based on field investigation activities discussed in the CAU 130 SAFER Plan (NNSA/NSO, 2008). The technical approach consisted of the activities listed in Table D.2-1. The investigation strategy allowed the nature and extent of contamination associated with each CAS to be established, if necessary. Although the initial sampling was planned based on the potential presence of USTs, three CASs within CAU 130 (01-02-01, 07-02-01, and 10-02-01) were determined to never have contained USTs. During the execution of the field investigation, the CSM was still applicable to these three sites and the analytical suites for each CAS were extensive enough to ensure that any releases of contamination would be identified. The following subsections describe the specific investigation activities that took place at CAU 130.

\section{D.2.2.1 Radiological Surveys}

Radiological surveys (i.e., scanning, static, and swipe collection) were performed at the CASs as needed during the CAI. Radiological surveys were performed to identify the presence, nature, and extent of radiological contaminants at activities statistically greater than background. The radiological walkover surveys were conducted using a handheld plastic scintillation detector in conjunction with a GPS receiver and datalogger. To conduct radiological static surveys to detect alpha and beta/gamma radiation, a handheld instrument was held within an inch over the sample for one minute. To support unrestricted release determinations per the NV/YMP Radiological Control (RadCon) Manual (NNSA/NSO, 2004), radiological surveys were performed at the appropriate CASs using various alpha and beta/gamma radiation detectors.

\section{D.2.2.2 Field Screening}

Field-screening activities for VOCs, alpha and beta/gamma radiation, and gamma-emitting radionuclides were performed as specified in the CAU 130 SAFER Plan (NNSA/NSO, 2008), when 
necessary. The field-screening level (FSL) for VOC headspace was established at 20 parts per million (ppm) or 2.5 times background, whichever was greater. Site-specific FSLs for alpha and beta/gamma radiation were defined as the mean background activity level, plus two times the standard deviation of readings from 10 background locations selected near each CAS. The radiation FSLs are instrument-specific and were established for each instrument and CAS before use. The FSLs for gamma-emitting radionuclides were compared to the PALs established in the CAU 130 SAFER Plan.

The CAS-specific sections of this document identify the CASs where field screening was conducted and how the FSLs were used to aid in the selection of sample locations. Field-screening results (FSRs) are recorded on SCLs that are retained in project files.

\section{D.2.2.3 Surface and Subsurface Soil Sampling}

Soil samples were collected using “scoop and trowel” (surface hand-grab sampling) and subsurface using a backhoe. All sample locations were initially field screened for alpha and beta/gamma radiation before the start of sampling. Additional screening was conducted during sample collection to both guide the investigation and serve as a health and safety control to protect the sampling team. Labeled sample containers were filled according to the following sequence: VOCs and TPH-GRO sample containers were filled with soil directly from the sample location, followed by the collection of soil for VOC field screening using headspace analysis when necessary. Additional soil was transferred into a stainless-steel pan, homogenized, and field screened for alpha and beta/gamma radiation. Samples for the analysis of gamma radiation and TPH-DRO were then collected from the homogenized soil. All remaining sample containers were then filled. Excess soil was returned to its original location.

Surface soil samples were collected from 0.0 to $0.5 \mathrm{ft}$ bgs at biased locations focusing on stained soil, aboveground features (i.e., concrete pads, exposed pipes), or areas with elevated radiological measurements.

Subsurface soil samples were collected as a continuation of surface soil sample locations where native soil interface was determined, where visible staining was noted, or where connections were identified along the UST piping to the structures. 


\section{D.2.2.4 Waste Characterization Sampling}

Characterization of CAS-specific components, objects, materials, and waste was performed to support recommendations for disposal of these items during anticipated closure activities and to determine whether the waste in question at these CASs could be acting as a source of potential soil contamination. Investigation methods included visual inspection, radiological surveys, and direct sampling. Waste characterization activities were intended to gather adequate information and data about the CAS to support decisions regarding the disposal of materials located within each CAS.

Samples were analyzed in accordance with the CAU 130 SAFER Plan (NNSA/NSO, 2008). The specific analyses for each CAS are listed in CAS-specific sections, and the analytical results are compared to the federal limits for hazardous waste, NDEP hydrocarbon action limit, landfill acceptance criteria, and the limits in the NTS performance objective criteria (POC) (BN, 1995). The POC limits have been established for NTS hazardous waste generators to ensure that all hazardous waste being shipped off site contains no "added radioactivity."

Specific waste characterization sampling and analysis was conducted on the following potential waste streams:

- Tar residue from CAS 20-99-05

- Liquid from CAS 23-02-07

- Soil from below lead bricks from CAS 07-02-01

\section{D.2.2.5 Video Surveying}

A video survey was conducted of Station 7-235 at CAS 07-02-01 to determine whether there were items in the bunker that could pose an environmental risk. There were no other video surveys conducted at the CAU 130 CASs.

\section{D.2.3 Laboratory Analytical Information}

Chemical and radiological analyses were performed by Paragon Analytics, Inc., of Fort Collins, Colorado. The analytical suites and laboratory analytical methods used to analyze investigation samples are listed in Table D.2-2. Analytical results are reported in this appendix if they were detected above the MDCs. The complete laboratory data packages are available in the project files. 
Table D.2-2

Laboratory Analyses and Methods, CAU 130 Investigation Samples $^{\mathrm{a}}$

\begin{tabular}{|c|c|}
\hline Analysis & 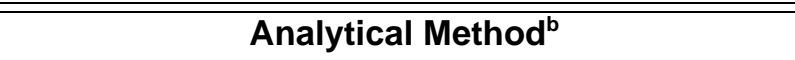 \\
\hline VOCs & Aqueous/Non-aqueous - EPA SW- $846^{c} 8260$ \\
\hline TCLP VOCs & EPA SW-846 $1311 / 8260$ \\
\hline SVOCs & Aqueous/Non-aqueous - EPA SW- $846^{c} 8270$ \\
\hline TCLP SVOC & EPA SW-846' $1311 / 8270$ \\
\hline PCBs & Aqueous/Non-aqueous - EPA SW-846 8082 \\
\hline TPH-GRO & Aqueous/Non-aqueous - EPA SW-846 8015 Modified \\
\hline TPH-DRO & Aqueous/Non-aqueous - EPA SW-846 ${ }^{\mathrm{C}} 8015$ Modified \\
\hline Pesticides & Aqueous/Non-aqueous - EPA SW-846 8081 \\
\hline Metals & $\begin{array}{c}\text { Aqueous - EPA SW-846 } 6010 / 6020 / 7470 \\
\text { Non-aqueous - EPA SW-846 6010/6020/7471 }\end{array}$ \\
\hline TCLP Metals & EPA SW-846 ${ }^{c} 1311 / 6010 / 7470$ \\
\hline Isotopic U & Aqueous/Non-aqueous - DOE EML HASL-300 d U-02-RC \\
\hline Isotopic Pu & $\begin{array}{c}\text { Aqueous - DOE EML HASL-300 }{ }^{d} \mathrm{Pu}-10-\mathrm{RC} \\
\text { Non-aqueous - DOE EML HASL-300 } \mathrm{Pu}-02-\mathrm{RC}\end{array}$ \\
\hline Gamma Spectroscopy & $\begin{array}{c}\text { Aqueous - EPA 901.1 }{ }^{\mathrm{e}} \\
\text { Non-aqueous - DOE EML HASL-300 }{ }^{\mathrm{d}}, \mathrm{Ga}-01-\mathrm{R}\end{array}$ \\
\hline Sr-90 & $\begin{array}{c}\text { Aqueous - EPA 905.0 } \\
\text { Non-aqueous - DOE EML HASL-300 } \mathrm{Sr}-02-\mathrm{RC}\end{array}$ \\
\hline Gross Alpha/Beta & $\begin{array}{c}\text { Aqueous - EPA 900.0 } \\
\text { Non-aqueous - SM } 7110 \mathrm{~B}^{\mathrm{f}} \text { Modified }\end{array}$ \\
\hline Tritium & $\begin{array}{l}\text { Aqueous - EPA } 906.0^{\mathrm{e}} \\
\text { Non-aqueous }^{\mathrm{b}}\end{array}$ \\
\hline
\end{tabular}

aInvestigation samples include both environmental and waste characterization samples and associated QC samples.

${ }^{\mathrm{b}}$ The most current EPA, DOE, ASTM, NIOSH, or equivalent accepted analytical method may be used, including Laboratory Standard Operating Procedures approved by SNJV in accordance with industry standards and the SNJV Statement of Work requirements (SNJV, 2006).

${ }^{\mathrm{c} T e s t}$ Methods for Evaluating Solid Waste, Physical/Chemical Methods (EPA, 2008).

${ }^{\mathrm{d}}$ The Procedures Manual of the Environmental Measurements Laboratory (DOE, 1997).

ePrescribed Procedures for Measurement of Radioactivity in Drinking Water (EPA, 1980).

'Standard Methods for the Examination of Water and Wastewater (Clesceri, et al., 1998).

Note: The term "modified" indicates modifications of approved methods. All modifications have been approved by SNJV's Analytical Services Department.

ASTM = American Society for Testing and Materials

$\mathrm{EML}=$ Environmental Measurements Laboratory

EPA $=$ U.S. Environmental Protection Agency

HASL = Health and Safety Laboratory

$\mathrm{NIOSH}=$ National Institute for Occupational Safety and Health 
The analytical parameters are CAS-specific and were selected through the application of site process knowledge according to the DQOs presented in Appendix A. Validated analytical data for CAU 130 investigation samples have been compiled and evaluated to confirm the presence of contamination and define the extent of contamination, if present. The analytical results for each CAS are presented in Sections D.3.0 through D.9.0.

\section{D.2.4 Comparison to Action Levels}

A COC is defined as any contaminant present in environmental media exceeding a FAL. A COC may also be defined as a contaminant that, in combination with other like contaminants, is determined to jointly pose an unacceptable risk based on a multiple constituent analysis (NNSA/NSO, 2006). Multiple constituent analyses are presented in Appendix H.

If COCs are present in a CAS, corrective action must be considered. The CAU 130 investigation FALs are defined for each CAS in Appendix H. Results that are equal to or greater than FALs are identified by bold text in the CAS-specific results tables (Sections D.3.0 through D.9.0).

The presence of a COC would require a corrective action. A corrective action may also be necessary if there is a potential for wastes present at a site (i.e., PSM) to release COCs into site environmental media.

To evaluate PSM for the potential to introduce a COC into the surrounding environmental media, the following conservative assumptions were made:

- Any physical waste containment would fail at some point, and the contents would be released to the surrounding media.

- The resulting concentration of contaminants in the surrounding media would be equal to the concentration of contaminants in the waste.

- Any liquid waste containing a contaminant exceeding the RCRA toxicity characteristic concentration would cause a COC to be present in the surrounding media if the liquid were released.

- Any non-liquid waste containing a contaminant exceeding an equivalent FAL concentration would cause a COC to be present in the surrounding media. 


\section{D.3.0 CAS 01-02-01, Underground Storage Tank, Investigation Results}

Corrective Action Site 01-02-01 is located in Area 1 within the Apple II District near the center of the NTS on the western side of Yucca Flat (Figure D.1-1). A natural gas underground distribution system exists between Buildings 1-31.1e1 and 1-31.4b1. Several components were identified in the SAFER Plan for investigation, including the excavation of a potential UST and the determination of the configuration of the underground piping. The images in Figure D.3-1 reflect the sample points and CAS 01-02-01 before, during, and after investigation activities. Additional history and process knowledge is provided in the SAFER Plan (NNSA/NSO, 2008).

\section{D.3.1 SAFER Activities}

The SAFER Plan CAI included the investigation of a potential UST. The CAI resulted in the location and determination of a natural gas underground distribution system between Buildings 1-31.1e1 and 1-31.4b1. A total of three characterization samples (including one FD) were collected during investigation activities at CAS 01-02-01. The sample ID, location, type, and analyses are listed in Table D.3-1. The specific CAI activities conducted to satisfy the SAFER Plan requirements at this CAS are described in the following sections.

\section{D.3.1.1 Field Screening}

Investigation samples were field screened for alpha and beta/gamma radiation. The FSRs were compared to FSLs to guide subsequent sampling decisions where appropriate. Field screening radiological FSLs were not exceeded in any samples.

\section{D.3.1.2 Geophysical Results}

The geophysical survey performed at CAS 01-02-01 indicated significant portions of the survey area have no surface or subsurface metal. Anomalies were detected near the location of the two concrete and metal structures that the excavation confirmed are Buildings 1-31.1e1 and 1-31.4b1. There was an anomaly detected at the location of the exposed pipe that is typical of a steel vertical stickup pipe and not a UST. The CAI confirmed the geophysical survey with the determination of a natural gas 


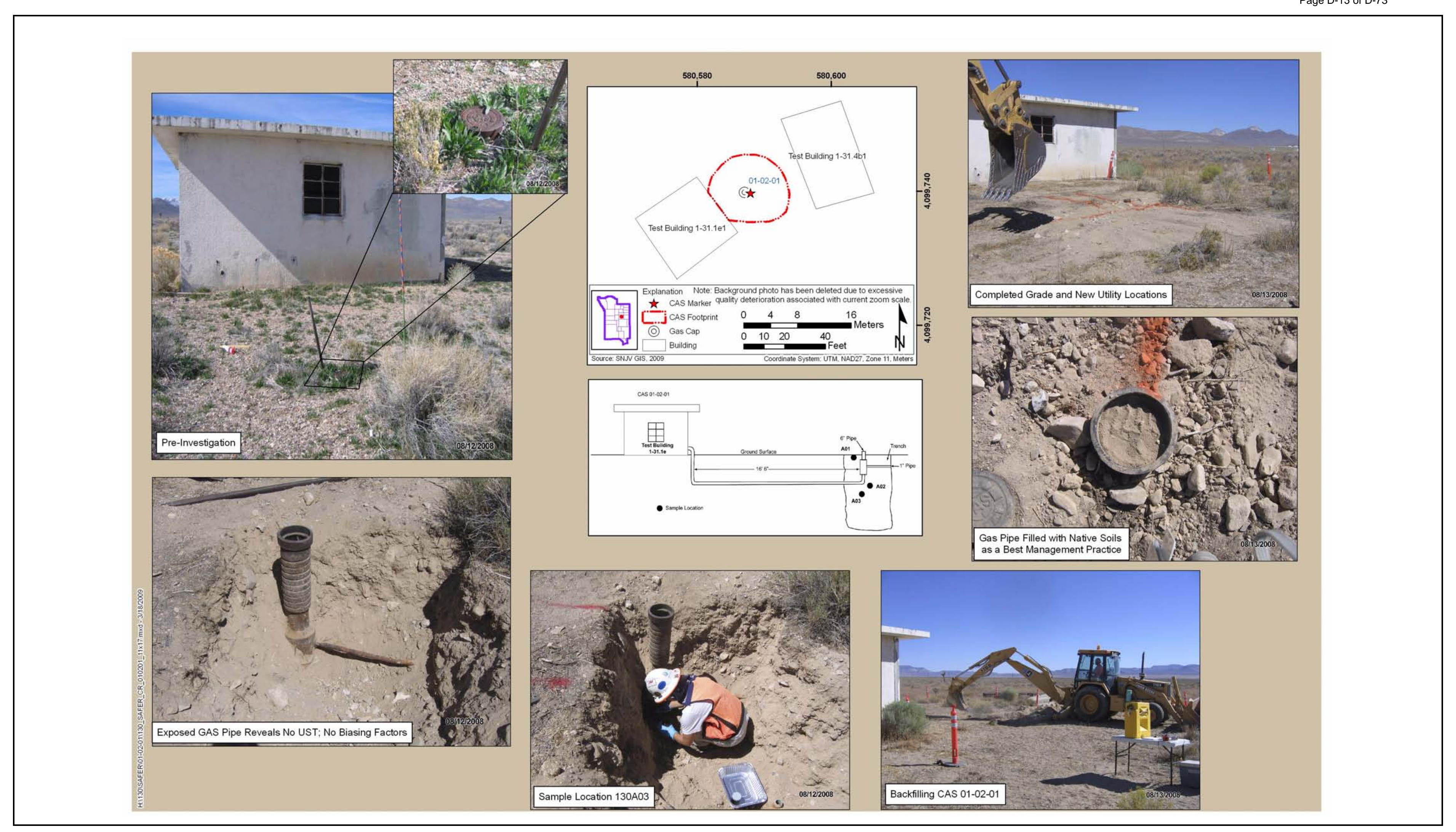

Figure D.3-1

Investigation Activities at CAS 01-02-01, Underground Storage Tank 
underground distribution system and no UST. Soil samples were collected and analyzed in accordance with the SAFER Plan. The site was backfilled, and the "GAS" pipe was filled with native soils as a BMP.

\section{D.3.1.3 Radiological Surveys}

An aerial radiological survey was conducted of the NTS including the area of CAS 01-02-01. The survey measured the terrestrial gamma radiation of natural and man-made radiation. This survey determined the radiation levels to be indistinguishable from background (BN, 1999).

Table D.3-1

Samples Collected at CAS 01-02-01, Underground Storage Tank

\begin{tabular}{|c|c|c|c|c|c|c|c|c|c|c|}
\hline $\begin{array}{c}\text { Sample } \\
\text { Location }\end{array}$ & $\begin{array}{l}\text { Sample } \\
\text { Number }\end{array}$ & $\begin{array}{l}\text { Depth } \\
\text { (ft bgs) }\end{array}$ & Matrix & Purpose & $\begin{array}{l}\text { 옴 } \\
\text { 品 }\end{array}$ & 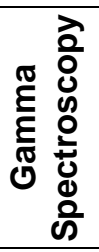 & 옹 & 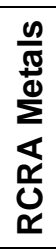 & 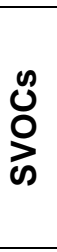 & $\begin{array}{l}\text { Uू } \\
\text { O }\end{array}$ \\
\hline$\overline{\mathrm{A} 01}$ & 130A001 & $0.0-0.5$ & Soil & Environmental & $\bar{X}$ & $\overline{\bar{X}}$ & $\bar{X}$ & $\bar{X}$ & $\bar{x}$ & $\bar{x}$ \\
\hline \multirow{2}{*}{ A02 } & $130 \mathrm{A002}$ & $2.5-3.0$ & Soil & Environmental & $\bar{x}$ & $\bar{x}$ & $\bar{X}$ & $\bar{x}$ & $\bar{x}$ & $\bar{x}$ \\
\hline & $130 \mathrm{~A} 003$ & $2.5-3.0$ & Soil & FD of \#130A002 & $\bar{x}$ & $\bar{x}$ & $\bar{x}$ & $\bar{x}$ & $x$ & $\bar{x}$ \\
\hline A03 & $130 \mathrm{~A} 004$ & $3.0-3.5$ & Soil & Environmental & $\bar{x}$ & $\bar{x}$ & $\bar{x}$ & $\bar{x}$ & $\bar{x}$ & $\bar{x}$ \\
\hline $\mathrm{N} / \mathrm{A}$ & 130A301 & $\mathrm{N} / \mathrm{A}$ & Water & Trip Blank & - & -- & - & - & -- & $\bar{x}$ \\
\hline $\mathrm{N} / \mathrm{A}$ & 130A302 & $\mathrm{N} / \mathrm{A}$ & Water & Trip Blank & -- & -- & -- & -- & -- & $\bar{x}$ \\
\hline $\mathrm{N} / \mathrm{A}$ & 130A303 & $\mathrm{N} / \mathrm{A}$ & Water & Field Blank & $\mathrm{X}$ & $\mathrm{X}$ & $\mathrm{X}$ & $\mathrm{X}$ & $x$ & $\bar{x}$ \\
\hline
\end{tabular}

-- = Not required

\section{D.3.1.4 Visual Inspections}

There was no visible staining or other biasing factors identified at CAS 01-02-01.

\section{D.3.1.5 Video Surveys}

No video surveys were conducted at CAS 01-02-01.

\section{D.3.1.6 Sample Collection}

Decision I environmental sampling activities included the collection of a surface soil sample from beside the surface "GAS" pipe. The subsurface soil samples were collected adjacent to and below the 
excavated connections to determine, if any, release (Figure D.3-1). No samples were collected associated with a UST because no UST was present.

\section{D.3.1.7 Deviations}

Investigation samples were collected as outlined in the SAFER Plan and submitted for laboratory analysis. There were no deviations from the SAFER Plan.

\section{D.3.2 Investigation Results}

The following sections provide analytical results from the samples collected to complete investigation activities as outlined in the SAFER Plan. Investigation samples were analyzed for the SAFER Plan-specified COPCs, which included VOCs, SVOCs, TPH-DRO, TPH-GRO, RCRA metals, and gamma-emitting radionuclides. The analytical parameters and laboratory methods used to analyze the investigation samples are listed in Table D.2-2. Table D.3-1 lists the sample-specific analytical suite for CAS 01-02-01.

Analytical results from the environmental samples with concentrations exceeding MDCs are summarized in the following sections. An evaluation was conducted on all contaminants detected above MDCs by comparing individual concentration or activity results against the FALs. Establishment of the FALs is presented in Sections H.1.7 and H.1.11. The FALs were established as the corresponding PAL concentrations or activities if the contaminant concentrations were below their respective PALs.

\section{D.3.2.1 Volatile Organic Compounds}

No VOCs were detected above MDCs at CAS 01-02-01. The FALs were established at the PAL concentrations.

\section{D.3.2.2 Semivolatile Organic Compounds}

Analytical results for SVOCs in environmental samples collected at this CAS that were detected above MDCs are presented in Table D.3-2. No SVOCs were detected at concentrations exceeding the respective PALs. The FALs were established at the PAL concentrations. 
Table D.3-2

Sample Results for SVOCs Detected above MDCs at CAS 01-02-01, Underground Storage Tank

\begin{tabular}{|c|c|c|c|c|}
\hline \multirow{2}{*}{$\begin{array}{c}\text { Sample } \\
\text { Location }\end{array}$} & \multirow{2}{*}{$\begin{array}{c}\text { Sample } \\
\text { Number }\end{array}$} & \multirow{2}{*}{$\begin{array}{c}\text { Depth } \\
\text { (ft bgs) }\end{array}$} & Fluoranthene & Phenanthrene \\
\cline { 4 - 5 } & & & $\mathbf{2 2 , 0 0 0}$ & $\mathbf{1 0 0 , 0 0 0}$ \\
\hline \multicolumn{3}{|c|}{ FALs } & $0.1(\mathrm{~J})$ & $0.084(\mathrm{~J})$ \\
\hline \hline $\mathrm{A} 02$ & $130 \mathrm{~A} 003$ & $2.5-3.0$ & & COPC (mg/kg) \\
\hline
\end{tabular}

$\mathrm{J}=$ Estimated value

\section{D.3.2.3 Total Petroleum Hydrocarbons}

Analytical results for TPH-DRO in soil samples collected at this CAS that were detected above MDCs are presented in Table D.3-3. No TPH-DRO was detected at a concentration exceeding the $100 \mathrm{mg} / \mathrm{kg}$ PAL. The FAL was established at the PAL concentration. No TPH-GRO was detected above MDCs at CAS 01-02-01.

Table D.3-3

Sample Results for TPH-DRO Detected above MDCs at CAS 01-02-01, Underground Storage Tank

\begin{tabular}{|c|c|c|c|}
\hline \multirow{2}{*}{$\begin{array}{c}\text { Sample } \\
\text { Location }\end{array}$} & $\begin{array}{c}\text { Sample } \\
\text { Number }\end{array}$ & $\begin{array}{c}\text { Depth } \\
\text { (ft bgs) }\end{array}$ & COPC (mg/kg) \\
\cline { 4 - 4 } & & & $\mathbf{1 0 0}$ \\
\hline \hline \multicolumn{3}{|c|}{ FAL } & $3.7(\mathrm{~J})$ \\
\hline $\mathrm{A} 02$ & $130 \mathrm{~A} 003$ & $2.5-3.0$ & $4.8(\mathrm{~J})$ \\
\hline $\mathrm{A} 03$ & $130 \mathrm{~A} 004$ & $3.0-3.5$ & DRO \\
\hline
\end{tabular}

$\mathrm{J}=$ Estimated value

\section{D.3.2.4 RCRA Metals}

Analytical results for RCRA metals in environmental samples collected at this CAS that were detected above MDCs are presented in Table D.3-4. No metals were detected at concentrations exceeding their PALs. The FALs were established at the PAL concentrations. 
Table D.3-4

Sample Results for RCRA Metals Detected above MDCs at CAS 01-02-01, Underground Storage Tank

\begin{tabular}{|c|c|c|c|c|c|c|c|c|}
\hline \multirow[b]{2}{*}{$\begin{array}{l}\text { Sample } \\
\text { Location }\end{array}$} & \multirow[b]{2}{*}{$\begin{array}{l}\text { Sample } \\
\text { Number }\end{array}$} & \multirow[b]{2}{*}{$\begin{array}{l}\text { Depth } \\
\text { (ft bgs) }\end{array}$} & \multicolumn{6}{|c|}{ COPC (mg/kg) } \\
\hline & & & 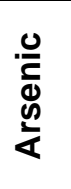 & 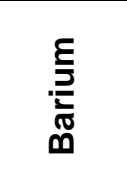 & 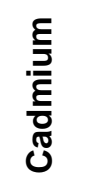 & $\begin{array}{l}\underline{\Xi} \\
. \bar{\Xi} \\
\bar{\partial} \\
\bar{\iota}\end{array}$ & ్ָర & $\begin{array}{l}\stackrel{\lambda}{\bar{J}} \\
\frac{d}{d} \\
\sum\end{array}$ \\
\hline \multicolumn{3}{|c|}{ FALs } & 23 & 67,000 & 450 & 450 & 800 & 310 \\
\hline$\overline{\mathrm{A} 01}$ & 130A001 & $0.0-0.5$ & 3.7 & 140 & 0.2 & 6.8 & $11(\mathrm{~J})$ & $\overline{0.0099(\mathrm{~J}+)}$ \\
\hline \multirow{2}{*}{ A02 } & $130 \mathrm{~A} 002$ & $2.5-3.0$ & 4.1 & 150 & 0.17 & 5.7 & $6.8(\mathrm{~J})$ & $0.012(\mathrm{~J}+)$ \\
\hline & $130 \mathrm{~A} 003$ & $2.5-3.0$ & 3.7 & 190 & 0.17 & 5.5 & $7.2(\mathrm{~J})$ & $0.016(\mathrm{~J}+)$ \\
\hline $\mathrm{A} 03$ & 130A004 & $3.0-3.5$ & 5 & 160 & 0.24 & 6 & $9.3(\mathrm{~J})$ & $0.015(\mathrm{~J}+)$ \\
\hline
\end{tabular}

$\mathrm{J}=$ Estimated value

$\mathrm{J}+=$ The result is an estimated quantity, but the result may be biased high.

\section{D.3.2.5 Gamma-Emitting Radionuclides}

Analytical results for gamma-emitting radionuclides in environmental samples collected at this CAS that were detected above MDCs are presented in Table D.3-5. No gamma-emitting radionuclides were detected at concentrations exceeding their PALs. Because the gamma-emitting radionuclides were less than the PAL, no further isotopic analysis was necessary. The FALs were established at the PAL concentrations.

Table D.3-5

Sample Results for Gamma-Emitting Radionuclides Detected above MDCs at CAS 01-02-01, Underground Storage Tank

\begin{tabular}{|c|c|c|c|c|c|c|c|}
\hline \multirow{2}{*}{$\begin{array}{l}\text { Sample } \\
\text { Location }\end{array}$} & \multirow{2}{*}{$\begin{array}{l}\text { Sample } \\
\text { Number }\end{array}$} & \multirow{2}{*}{$\begin{array}{l}\text { Depth } \\
\text { (ft bgs) }\end{array}$} & \multicolumn{5}{|c|}{ COPC (pCi/g) } \\
\hline & & & AC-228 & Am-241 & $\mathrm{Pb}-212$ & $\mathrm{~Pb}-214$ & Tl-208 \\
\hline \multicolumn{3}{|c|}{ FALs } & 5 & 12.7 & 5 & 5 & 5 \\
\hline$\overline{\mathrm{A} 01}$ & 130A001 & $0.0-0.5$ & $\overline{1.44}$ & $0.37(\mathrm{~J})$ & $1.66(\mathrm{~J})$ & $1.18(\mathrm{~J})$ & $\overline{0.58}$ \\
\hline \multirow{2}{*}{ A02 } & 130A002 & $2.5-3.0$ & 1.29 & -- & $1.75(\mathrm{~J})$ & $1.28(\mathrm{~J})$ & 0.55 \\
\hline & 130A003 & $2.5-3.0$ & 1.2 & -- & $1.68(\mathrm{~J})$ & $1.12(\mathrm{~J})$ & 0.57 \\
\hline A03 & 130A004 & $3.0-3.5$ & 1.46 & -- & $1.79(\mathrm{~J})$ & $1.06(\mathrm{~J})$ & 0.51 \\
\hline
\end{tabular}

$\mathrm{Ac}=$ Actinium

$\mathrm{Pb}=$ Lead

$\mathrm{pCi} / \mathrm{g}=$ Picocuries per gram

$\mathrm{TI}=$ Thallium

-- = Not detected above MDCs.

$\mathrm{J}=$ Estimated value 


\section{D.3.3 Nature and Extent of Contamination}

Based on the results of the CAI including the analytical results for environmental samples collected, there are no COCs at CAS 01-02-01.

\section{D.3.4 Revised Conceptual Site Model}

The CSM modeled the potential for UST and potential associated piping. Because the CAI determined no UST but did find an underground former distribution system, the SAFER Plan requirements were met at this CAS, and no revisions were necessary to the CSM. 


\section{D.4.0 CAS 07-02-01, Underground Storage Tanks, Investigation} Results

Corrective Action Site 07-02-01 is located in Area 7 east of the T7c atmospheric test site

(Figure D.1-1). The CAS location is at an instrumentation shelter area that includes Station 7-235. Several components were identified in the SAFER Plan for investigation, including the excavation of potential USTs, removal of PSM (lead bricks), eight Eveready dry cell batteries, and the determination of Station 7-235. The images in Figure D.4-1 reflect the sample points and CAS 07-02-01 before, during, and after investigation activities. Additional history and process knowledge is provided in the SAFER Plan (NNSA/NSO, 2008).

\section{D.4.1 SAFER Activities}

The SAFER Plan CAI included the investigation of potential USTs. The investigation revealed an instrumentation shelter, Station 7-235, and five other concrete pads. There were no USTs. A total of five characterization samples (including one FD) were collected during investigation activities at CAS 07-02-01. The sample ID, location, type, and analyses are listed in Table D.4-1. The specific CAI activities conducted to satisfy the SAFER Plan requirements at this CAS are described in the following sections.

\section{D.4.1.1 Field Screening}

Investigation samples were field screened for alpha and beta/gamma radiation. The FSRs were compared to FSLs to guide subsequent sampling decisions where appropriate. Field-screening radiological FSLs were not exceeded in any samples.

\section{D.4.1.2 Geophysical Results}

The geophysical survey performed at CAS 07-02-01 detected a large anomaly that measured approximately 70 by $40 \mathrm{ft}$ with four subfeatures within its boundaries. The excavation of this site confirmed that the geophysical anomalies were associated with the bunker, Station 7-235, and five concrete pads. No USTs were discovered during the CAI. Soil samples were collected and analyzed in accordance with the SAFER Plan. 


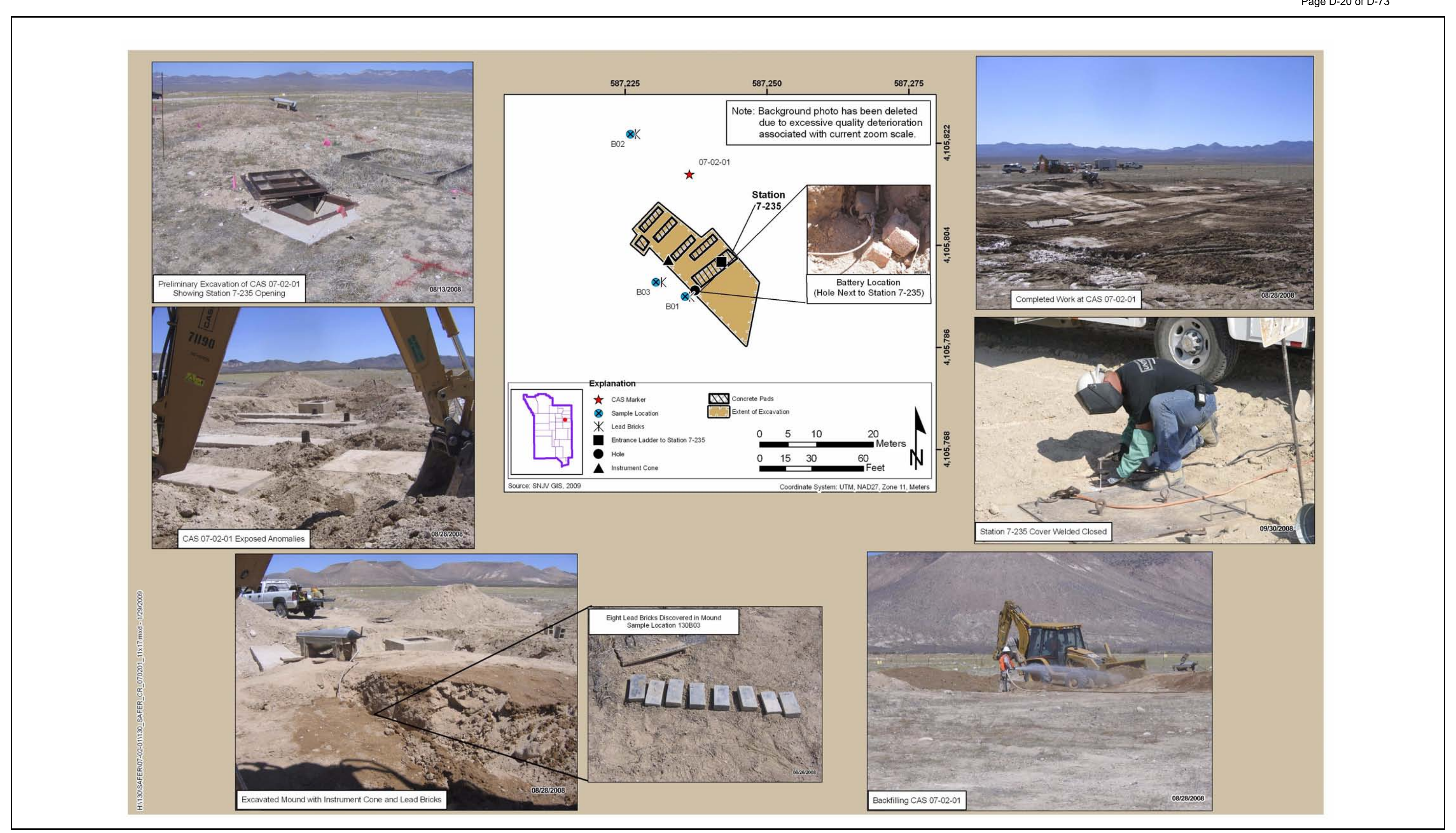

Figure D.4-1

Investigation Activities at CAS 07-02-01, Underground Storage Tanks 
Table D.4-1

Samples Collected at CAS 07-02-01, Underground Storage Tanks

\begin{tabular}{|c|c|c|c|c|c|c|c|c|c|c|c|c|}
\hline $\begin{array}{l}\text { Sample } \\
\text { Location }\end{array}$ & $\begin{array}{l}\text { Sample } \\
\text { Number }\end{array}$ & $\begin{array}{c}\text { Depth } \\
\text { (ft bgs) }\end{array}$ & Matrix & Purpose & 옴 & 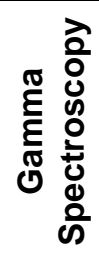 & 足 & 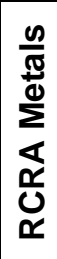 & 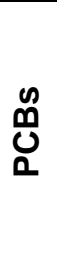 & $\sum_{\text {in }}^{00}$ & 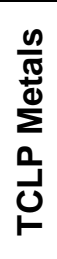 & $\begin{array}{l}\text { O্ } \\
\text { O্ }\end{array}$ \\
\hline B01 & 130B001 & $0.0-0.5$ & Soil & Environmental & $x$ & $x$ & $x$ & $x$ & $x$ & $x$ & -- & $\mathrm{x}$ \\
\hline \multirow{2}{*}{ B02 } & 130B002 & $0.0-0.5$ & Soil & Environmental & $x$ & $x$ & $x$ & $x$ & $x$ & $x$ & $x$ & $\mathrm{x}$ \\
\hline & 130B003 & $0.0-0.5$ & Soil & FD of $\# 130 B 002$ & $x$ & $x$ & $x$ & $x$ & $\mathrm{x}$ & $\mathrm{X}$ & -- & $x$ \\
\hline B03 & 130B004 & $0.5-1.0$ & Soil & Environmental & $x$ & $x$ & $x$ & $x$ & $x$ & $x$ & -- & $\mathrm{x}$ \\
\hline B04 & 130B005 & $3.0-3.5$ & Soil & Environmental & $x$ & $x$ & $x$ & $x$ & $x$ & $x$ & -- & $x$ \\
\hline N/A & 130B301 & $N / A$ & Water & Trip Blank & -- & -- & -- & -- & -- & -- & -- & $\mathrm{x}$ \\
\hline $\mathrm{N} / \mathrm{A}$ & 130B302 & $N / A$ & Water & Trip Blank & -- & -- & -- & -- & -- & -- & -- & $x$ \\
\hline $\mathrm{N} / \mathrm{A}$ & 130В303 & N/A & Water & Field Blank & $x$ & $x$ & $x$ & $x$ & $x$ & $x$ & -- & $\mathrm{x}$ \\
\hline $\mathrm{N} / \mathrm{A}$ & 130B304 & $\mathrm{N} / \mathrm{A}$ & Water & Trip Blank & -- & -- & -- & -- & -- & -- & -- & $x$ \\
\hline N/A & 130B305 & N/A & Water & Trip Blank & -- & -- & -- & -- & -- & -- & -- & $\mathrm{x}$ \\
\hline
\end{tabular}

-- = Not required

\section{D.4.1.3 Radiological Surveys}

A walkover radiological survey was conducted of CAS 07-02-01. The survey measured the terrestrial gamma radiation of natural and man-made radiation. This survey determined the radiation levels to be indistinguishable from background (Nicosia, 2003). Corrective Action Site 07-02-01 is within a posted contamination area; however, the contamination is not believed to originate from this CAS but is believed to be from ejected metal debris from atmospheric testing (DOE/NV, 2000). Because the contaminated material is not from CAS 07-02-01, a demarcation survey was performed. The results allowed this CAS to be downposted to a radiological materials area.

\section{D.4.1.4 Visual Inspections}

The biasing factors identified at CAS 07-02-01 included lead bricks and eight dry cell batteries. There was no visible staining identified. 


\section{D.4.1.5 Video Surveys}

A video survey was conducted of the inside of Station 7-235 to determine whether there was material or equipment present that could pose an environmental concern. The results of the survey indicated that there is no equipment or material in the bunker that is of environmental concern. No other video surveys were conducted at CAS 07-02-01.

\section{D.4.1.6 Sample Collection}

Decision I environmental sampling activities included the collection of surface soil samples below the lead bricks. A subsurface soil sample was collected below the dry cell batteries (Figure D.4-1). Although original information suggested the presence of a UST, none was found during the CAI.

\section{D.4.1.7 Deviations}

Investigation samples were collected and submitted for laboratory analysis as outlined in the SAFER Plan. There were two deviations to the SAFER Plan. First, eight dry cell batteries were discovered during the investigation, and a confirmation soil sample was collected from beneath the batteries to determine whether there had been a release. Second, eight lead bricks were discovered during the investigation and a confirmation soil sample was collected from beneath the bricks to determine whether there had been a release of lead to the environment. There were no other deviations from the SAFER Plan.

\section{D.4.2 Investigation Results}

The following sections provide analytical results from the samples collected to complete investigation activities as outlined in the SAFER Plan. Investigation samples were analyzed for the SAFER Plan-specified COPCs, which included VOCs, SVOCs, TPH-DRO, TPH-GRO, RCRA metals, PCBs, and gamma-emitting radionuclides. The analytical parameters and laboratory methods used to analyze the investigation samples are listed in Table D.2-2. Table D.4-1 lists the sample-specific analytical suite for CAS 07-02-01.

Analytical results from the environmental samples with concentrations exceeding MDCs are summarized in the following sections. An evaluation was conducted on all contaminants detected 
above MDCs by comparing individual concentration or activity results against the FALs. Establishment of the FALs is presented in Section H.1.0. The FALs were established as the corresponding PAL concentrations or activities if the contaminant concentrations were below their respective PALs.

\section{D.4.2.1 Volatile Organic Compounds}

Analytical results for VOCs in environmental samples collected at this CAS that were detected above MDCs are presented in Table D.4-2. No VOCs were detected at concentrations exceeding their respective PALs. The FALs were established at the PAL concentrations.

Table D.4-2

Sample Results for Total VOCs Detected above MDCs at CAS 07-02-01, Underground Storage Tanks

\begin{tabular}{|c|c|c|c|}
\hline \multirow{2}{*}{$\begin{array}{c}\text { Sample } \\
\text { Location }\end{array}$} & \multirow{2}{*}{$\begin{array}{c}\text { Sample } \\
\text { Number }\end{array}$} & $\begin{array}{c}\text { Depth } \\
\text { (ft bgs) }\end{array}$ & COPC (mg/kg) \\
\cline { 4 - 4 } & & & Acetone \\
\hline \multicolumn{3}{|c|}{ FAL } & $\mathbf{5 4 , 0 0 0}$ \\
\hline \hline B01 & 130 B001 & $0.0-0.5$ & $0.0089(\mathrm{~J})$ \\
\hline \multirow{2}{*}{ B02 } & $130 \mathrm{~B} 002$ & $0.0-0.5$ & $0.013(\mathrm{~J})$ \\
\cline { 2 - 5 } & $130 \mathrm{~B} 003$ & $0.0-0.5$ & $0.012(\mathrm{~J})$ \\
\hline
\end{tabular}

$\mathrm{J}=$ Estimated value

\section{D.4.2.2 Semivolatile Organic Compounds}

No SVOCs were detected above MDCs at CAS 07-02-01. The FAL was established at the PAL concentration.

\section{D.4.2.3 Total Petroleum Hydrocarbons}

Analytical results for TPH-DRO and -GRO in soil samples collected at this CAS that were detected above MDCs are presented in Table D.4-3. No TPH-DRO or -GRO was detected at concentrations exceeding the $100 \mathrm{mg} / \mathrm{kg}$ PAL. The FAL was established at the PAL concentration. 
Table D.4-3

Sample Results for TPH-DRO and -GRO Detected above MDCs at CAS 07-02-01, Underground Storage Tanks

\begin{tabular}{|c|c|c|c|c||}
\hline \multirow{2}{*}{$\begin{array}{c}\text { Sample } \\
\text { Location }\end{array}$} & \multirow{2}{*}{$\begin{array}{c}\text { Sample } \\
\text { Number }\end{array}$} & \multirow{2}{*}{$\begin{array}{c}\text { Depth } \\
\text { (ft bgs) }\end{array}$} & \multicolumn{2}{|c|}{ COPC (mg/kg) } \\
\cline { 4 - 5 } & & & DRO & GRO \\
\hline \multicolumn{3}{|c|}{ FALs } & $\mathbf{1 0 0}$ & $\mathbf{1 0 0}$ \\
\hline \hline B01 & $130 \mathrm{~B} 001$ & $0.0-0.5$ & $3.1(\mathrm{~J})$ & $0.096(\mathrm{~J})$ \\
\hline \multirow{2}{*}{ B02 } & $130 \mathrm{~B} 002$ & $0.0-0.5$ & -- & $0.13(\mathrm{~J})$ \\
\cline { 2 - 5 } & $130 \mathrm{~B} 003$ & $0.0-0.5$ & -- & $0.098(\mathrm{~J})$ \\
\hline
\end{tabular}

-- = Not detected above MDCs

$\mathrm{J}=$ Estimated value

\section{D.4.2.4 RCRA Metals}

Analytical results for RCRA metals in environmental samples collected at this CAS that were detected above MDCs are presented in Table D.4-4. No metals were detected at concentrations exceeding their PALs. The FALs were established at the PAL concentrations.

Table D.4-4

Sample Results for RCRA Metals Detected above MDCs at CAS 07-02-01, Underground Storage Tanks

\begin{tabular}{|c|c|c|c|c|c|c|c|c|}
\hline \multirow[b]{2}{*}{$\begin{array}{c}\text { Sample } \\
\text { Location }\end{array}$} & \multirow[b]{2}{*}{$\begin{array}{l}\text { Sample } \\
\text { Number }\end{array}$} & \multirow[b]{2}{*}{$\begin{array}{c}\text { Depth } \\
\text { (ft bgs) }\end{array}$} & \multicolumn{6}{|c|}{ COPC (mg/kg) } \\
\hline & & & 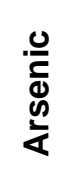 & 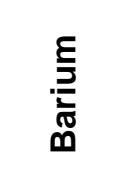 & 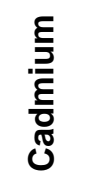 & 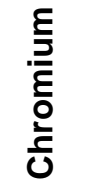 & $\begin{array}{l}\text { ర్తి } \\
\text { త్ }\end{array}$ & $\begin{array}{l}\stackrel{\lambda}{\bar{J}} \\
\frac{0}{d} \\
\sum\end{array}$ \\
\hline \multicolumn{3}{|c|}{ FALs } & 23 & 67,000 & 450 & 450 & 800 & 310 \\
\hline B01 & 130B001 & $0.0-0.5$ & 5.3 & 160 & 0.19 & 10 & $62(\mathrm{~J})$ & $0.028(\mathrm{~J}+)$ \\
\hline \multirow{2}{*}{ B02 } & 130B002 & $0.0-0.5$ & 3.6 & 150 & 0.15 & 8.4 & $220(\mathrm{~J})$ & $0.026(\mathrm{~J}+)$ \\
\hline & 130B003 & $0.0-0.5$ & 4.9 & 160 & 0.16 & 8.5 & $210(\mathrm{~J})$ & $0.031(\mathrm{~J}+)$ \\
\hline B03 & 130B004 & $0.5-1.0$ & 4.2 & 180 & 0.15 & 7.7 & 17 & 0.014 \\
\hline B04 & 130B005 & $3.0-3.5$ & 4 & 170 & 0.15 & 7.3 & 13 & 0.019 \\
\hline
\end{tabular}

$\mathrm{J}=$ Estimated value

$\mathrm{J}+=$ The result is an estimated quantity, but the result may be biased high. 


\section{D.4.2.5 Polychlorinated Biphenyls}

Analytical results for PCBs in environmental samples collected at this CAS that were detected above MDCs are presented in Table D.4-5. No PCBs were detected at concentrations exceeding their PALs. The FALs were established at the PAL concentrations.

Table D.4-5

Sample Results for PCBs Detected above MDCs at CAS 07-02-01, Underground Storage Tanks

\begin{tabular}{||c|c|c|c|}
\hline \hline $\begin{array}{c}\text { Sample } \\
\text { Location }\end{array}$ & $\begin{array}{c}\text { Sample } \\
\text { Number }\end{array}$ & $\begin{array}{c}\text { Depth } \\
\text { (ft bgs) }\end{array}$ & COPC (mg/kg) \\
\cline { 4 - 4 } & & Aroclor 1254 \\
\hline \multicolumn{3}{|c|}{ FAL } \\
\hline \hline B03 & $130 \mathrm{~B} 004$ & $0.5-1.0$ & $\mathbf{0 . 7 4}$ \\
\hline B04 & $130 \mathrm{~B} 005$ & $3.0-3.5$ & $0.054(\mathrm{~J})$ \\
\hline
\end{tabular}

$\mathrm{J}=$ Estimated value

\section{D.4.2.6 Gamma-Emitting Radionuclides}

Analytical results for gamma-emitting radionuclides in environmental samples collected at this CAS that were detected above MDCs are presented in Table D.4-6. No gamma-emitting radionuclides were detected at concentrations exceeding their PALs. Because the gamma-emitting radionuclides were less than the PAL, no further isotopic analysis was necessary. The FALs were established at the PAL concentrations.

\section{D.4.3 Nature and Extent of Contamination}

The PSM that was identified at CAS 07-02-01 was removed. Based on the results of the CAI including the analytical results for environmental samples collected, COCs were determined not to be present at CAS 07-02-01.

\section{D.4.4 Revised Conceptual Site Model}

The CSM for CAS 07-02-01 modeled potential USTs and potential bunkers. The SAFER Plan requirements were met at this CAS, even though the CSM was developed based on the potential presence of USTs, the bunker and associated concrete pads were modeled. Therefore, no revisions were necessary. 
Table D.4-6

Sample Results for Gamma-Emitting Radionuclides Detected above MDCs at CAS 07-02-01, Underground Storage Tanks

\begin{tabular}{|c|c|c|c|c|c|c|c|c|c|}
\hline \multirow{2}{*}{$\begin{array}{c}\text { Sample } \\
\text { Location }\end{array}$} & \multirow{2}{*}{$\begin{array}{l}\text { Sample } \\
\text { Number }\end{array}$} & \multirow{2}{*}{$\begin{array}{l}\text { Depth } \\
\text { (ft bgs) }\end{array}$} & \multicolumn{7}{|c|}{ COPC (pCi/g) } \\
\hline & & & Ac-228 & Am-241 & Cs-137 & Eu-152 & $\mathrm{Pb}-212$ & $\mathrm{~Pb}-214$ & TI-208 \\
\hline \multicolumn{3}{|c|}{ FALs } & 5 & 12.7 & 12.2 & 5.67 & 5 & 5 & 5 \\
\hline B01 & 130B001 & $0.0-0.5$ & 1.38 & -- & -- & -- & $1.55(\mathrm{~J})$ & $1.17(\mathrm{~J})$ & 0.54 \\
\hline \multirow{2}{*}{ B02 } & 130B002 & $0.0-0.5$ & 2.02 & -- & 0.25 & $2.58(\mathrm{~J})$ & $2.28(\mathrm{~J})$ & $0.97(\mathrm{~J})$ & 0.63 \\
\hline & 130В003 & $0.0-0.5$ & 1.86 & $0.53(\mathrm{~J})$ & -- & $2.61(\mathrm{~J})$ & $2.26(\mathrm{~J})$ & $1.18(\mathrm{~J})$ & 0.57 \\
\hline B03 & 130B004 & $0.5-1.0$ & 1.4 & -- & -- & -- & $1.75(\mathrm{~J})$ & $0.88(\mathrm{~J})$ & 0.52 \\
\hline B04 & 130B005 & $3.0-3.5$ & 1.39 & $1.18(\mathrm{~J})$ & 1.16 & $1.37(\mathrm{~J})$ & $1.6(\mathrm{~J})$ & $0.91(\mathrm{~J})$ & 0.56 \\
\hline
\end{tabular}

$\mathrm{Cs}=$ Cesium

$\mathrm{Eu}=$ Europium

-- = Not detected above MDCs.

$\mathrm{J}=$ Estimated value 


\section{D.5.0 CAS 10-02-01, Underground Storage Tank, Investigation Results}

Corrective Action Site 10-02-01 is located in Area 10 near the U10x crater from the Ward underground nuclear test (Figure D.1-1). The site had three pipes exposed approximately 12 in. above ground surface. The three pipes were connected to a concrete lid that revealed a battery vault. Several components were identified in the SAFER Plan for investigation, including the excavation of a potential UST and the identification of the aboveground piping. The images in Figure D.5-1 reflect the sample points and CAS 10-02-01 before, during, and after investigation activities. Additional history and process knowledge is provided in the SAFER Plan (NNSA/NSO, 2008).

\section{D.5.1 SAFER Activities}

The SAFER Plan CAI included the investigation of a potential UST. The investigation determined the site is a storage vault with 118 dry cell batteries. A total of 10 characterization samples (including 1 FD) were collected during investigation activities at CAS 10-02-01. The sample ID, location, type, and analyses are listed in Table D.5-1. The specific CAI activities conducted to satisfy the SAFER Plan requirements at this CAS are described in the following sections.

\section{D.5.1.1 Field Screening}

Investigation samples were field screened for alpha and beta/gamma radiation, and gamma radiation. The FSRs were compared to FSLs to guide subsequent sampling decisions where appropriate. Field screening radiological FSLs had two minor exceedences. Surface soil sample 130C001 collected from the contact of the southernmost exposed pipe, and surface soil sample 130C006 collected from the middle edge of the concrete structure had FSRs of 8,800 disintegrations per minute per 100 square centimeters $\left(\mathrm{dpm} / 100 \mathrm{~cm}^{2}\right)$ and $11,400 \mathrm{dpm} / 100 \mathrm{~cm}^{2}$, respectively. The FSL was $8,200 \mathrm{dpm} / 100 \mathrm{~cm}^{2}$. Gamma spectroscopy was submitted to the laboratory from both locations.

\section{D.5.1.2 Geophysical Results}

The geophysical survey conducted at CAS 10-02-01 identified a 25-ft-wide anomaly considered the geometric configuration of a UST. The excavation of the site confirmed the anomaly to be an 


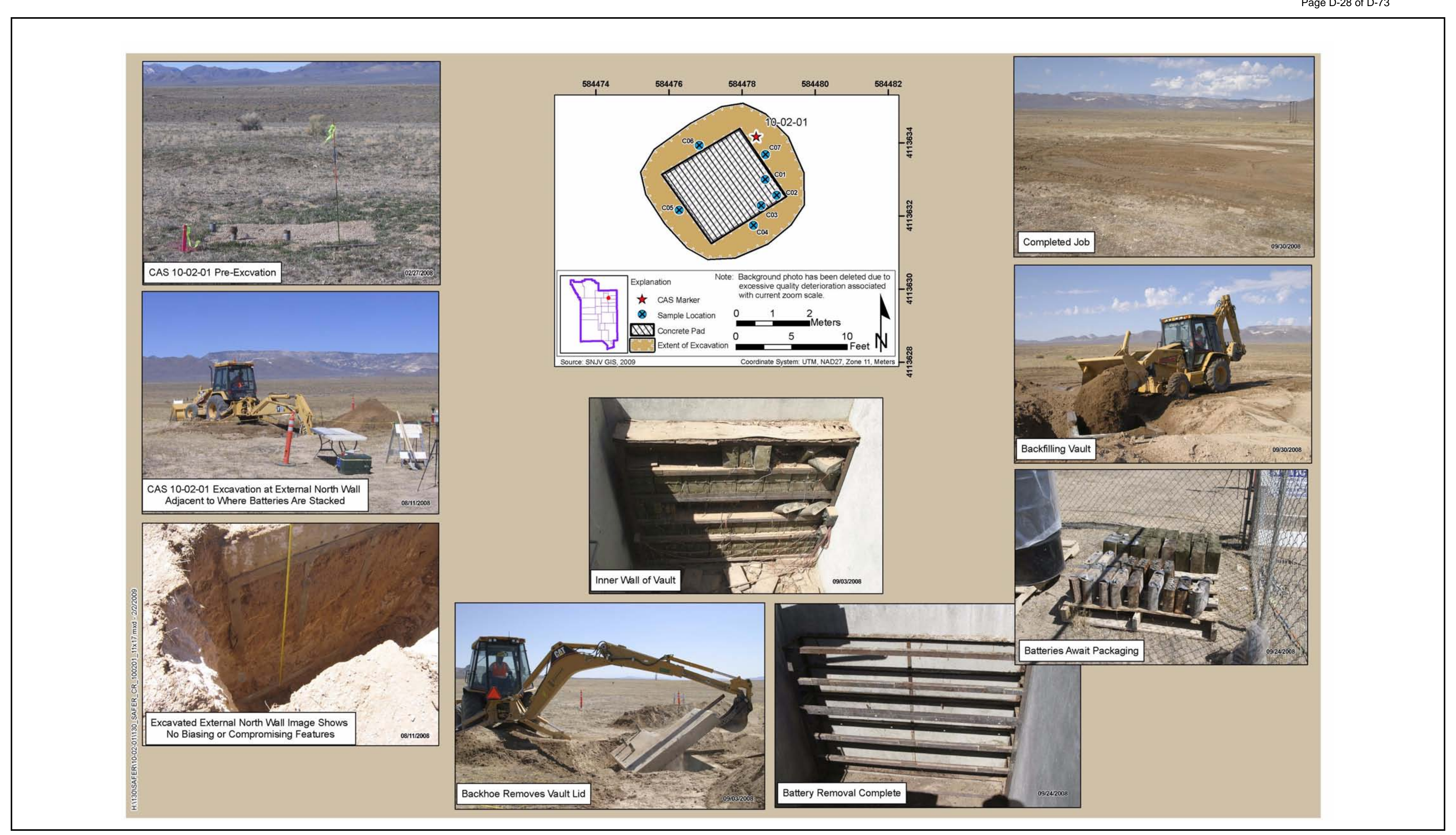

Figure D.5-1

Investigation Activities at CAS 10-02-01, Underground Storage Tank 
Table D.5-1

Samples Collected at CAS 10-02-01, Underground Storage Tank

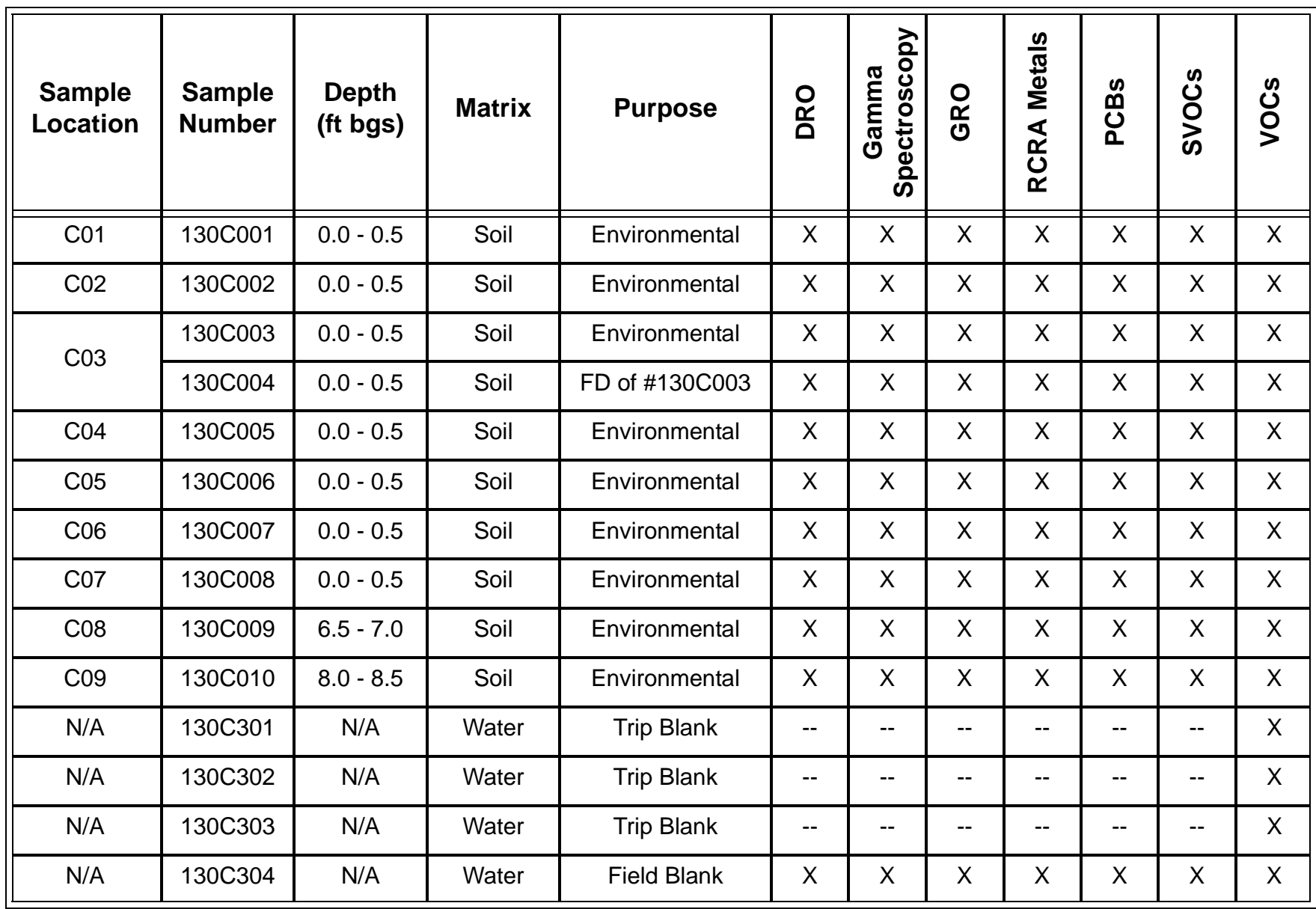

$--=$ Not required

underground storage vault and not a UST. The storage vault held 118 dry cell batteries that were disposed of, and confirmation soil samples were collected in accordance with the SAFER Plan.

\section{D.5.1.3 Radiological Surveys}

A radiological walkover survey was conducted of CAS 10-02-01. All readings were indistinguishable from background (Nicosia, 2003).

\section{D.5.1.4 Visual Inspections}

The biasing factors identified at CAS 10-02-01 included the storage vault and the 118 dry cell batteries. 


\section{D.5.1.5 Video Surveys}

No video surveys were conducted at CAS 10-02-01.

\section{D.5.1.6 Sample Collection}

Decision I environmental sampling activities included the collection of surface soil samples at the contact next to the exposed pipes and the middle edge of each side of the concrete structure. Subsurface soil samples were collected adjacent to the outside base of the concrete structure where the dry cell batteries were located (Figure D.5-1). No samples were collected associated with a UST because the site was a vault rather than a UST. Because a UST was not present at this CAS, the sampling did not follow the plan for a UST. However, sampling was adequate to identify any release that may have occurred from the vault.

\section{D.5.1.7 Deviations}

There was one deviation from the SAFER Plan. The investigation revealed a vault with 118 dry cell batteries. During the field effort, these batteries were removed, packaged, and disposed in the U10c Industrial Waste Landfill. Investigation samples were collected as outlined in the SAFER Plan and submitted for laboratory analysis. There were no other deviations from the SAFER Plan.

\section{D.5.2 Investigation Results}

The following sections provide analytical results from the samples collected to complete investigation activities as outlined in the SAFER Plan. Investigation samples were analyzed for the SAFER Plan-specified COPCs, which included VOCs, SVOCs, TPH-DRO, TPH-GRO, RCRA metals, PCBs, and gamma-emitting radionuclides. The analytical suite was more extensive for this CAS than a known UST site because of the uncertainty in the potential presence of a UST. The analytical parameters and laboratory methods used to analyze the investigation samples are listed in Table D.2-2. Table D.5-1 lists the sample-specific analytical suite for CAS 10-02-01.

Analytical results from the environmental samples with concentrations exceeding MDCs are summarized in the following sections. An evaluation was conducted on all contaminants detected above MDCs by comparing individual concentrations or activity results against the FALs. 
Establishment of the FALs is presented in Section H.1.0. The FALs were established as the corresponding PAL concentrations or activities if the contaminant concentrations were below their respective PALs.

\section{D.5.2.1 Volatile Organic Compounds}

Analytical results for VOCs in environmental samples collected at this CAS that were detected above MDCs are presented in Table D.5-2. No VOCs were detected at concentrations exceeding their respective PALs. The FALs were established at the PAL concentrations.

Table D.5-2

Sample Results for VOCs Detected above MDCs at CAS 10-02-01, Underground Storage Tank

\begin{tabular}{|c|c|c|c|}
\hline \multirow{2}{*}{$\begin{array}{c}\text { Sample } \\
\text { Location }\end{array}$} & \multirow{2}{*}{$\begin{array}{c}\text { Sample } \\
\text { Number }\end{array}$} & $\begin{array}{c}\text { Depth } \\
\text { (ft bgs) }\end{array}$ & COPC (mg/kg) \\
\cline { 4 - 4 } & & & Acetone \\
\hline \multicolumn{3}{|c|}{ FAL } & $\mathbf{5 4 , 0 0 0}$ \\
\hline \hline C02 & $130 \mathrm{C} 002$ & $0.0-0.5$ & $0.0089(\mathrm{~J})$ \\
\hline
\end{tabular}

$\mathrm{J}=$ Estimated value

\section{D.5.2.2 Semivolatile Organic Compounds}

Analytical results for SVOCs in environmental samples collected at this CAS that were detected above MDCs are presented in Table D.5-3. No SVOCs were detected at concentrations exceeding the respective PALs. The FALs were established at the PAL concentrations.

Table D.5-3

Sample Results for SVOCs Detected above MDCs at CAS 10-02-01, Underground Storage Tank

\begin{tabular}{|c|c|c|c|}
\hline \multirow{2}{*}{$\begin{array}{l}\text { Sample } \\
\text { Location }\end{array}$} & \multirow{2}{*}{$\begin{array}{l}\text { Sample } \\
\text { Number }\end{array}$} & \multirow{2}{*}{$\begin{array}{l}\text { Depth } \\
\text { (ft bgs) }\end{array}$} & COPC (mg/kg) \\
\hline & & & Bis(2-ethylhexyl)Phthalate \\
\hline \multicolumn{3}{|c|}{ FAL } & 120 \\
\hline C04 & $130 \mathrm{C} 005$ & $0.0-0.5$ & $0.29(\mathrm{~J})$ \\
\hline
\end{tabular}

$\mathrm{J}=$ Estimated value 


\section{D.5.2.3 Total Petroleum Hydrocarbons}

Analytical results for TPH-DRO and -GRO in soil samples collected at this CAS that were detected above MDCs are presented in Table D.5-4. No TPH-DRO or -GRO was detected at concentrations exceeding the $100 \mathrm{mg} / \mathrm{kg}$ PAL. The FAL was established at the PAL concentration.

Table D.5-4

Sample Results for TPH-DRO and -GRO Detected above MDCs at CAS 10-02-01, Underground Storage Tank

\begin{tabular}{|c|c|c|c|c|}
\hline \multirow{2}{*}{$\begin{array}{l}\text { Sample } \\
\text { Location }\end{array}$} & \multirow{2}{*}{$\begin{array}{l}\text { Sample } \\
\text { Number }\end{array}$} & \multirow{2}{*}{$\begin{array}{l}\text { Depth } \\
\text { (ft bgs) }\end{array}$} & \multicolumn{2}{|c|}{ COPC $(\mathrm{mg} / \mathrm{kg})$} \\
\hline & & & DRO & GRO \\
\hline \multicolumn{3}{|c|}{ FALs } & 100 & 100 \\
\hline $\mathrm{C} 01$ & $130 \mathrm{C001}$ & $0.0-0.5$ & 8 & $0.17(\mathrm{~J})$ \\
\hline $\mathrm{CO} 2$ & $130 \mathrm{C} 002$ & $0.0-0.5$ & -- & $0.083(\mathrm{~J})$ \\
\hline \multirow{2}{*}{$\mathrm{CO3}$} & $130 \mathrm{C003}$ & $0.0-0.5$ & -- & $0.096(\mathrm{~J})$ \\
\hline & $130 \mathrm{C004}$ & $0.0-0.5$ & -- & $0.29(\mathrm{~J})$ \\
\hline C05 & $130 C 006$ & $0.0-0.5$ & -- & $0.13(\mathrm{~J})$ \\
\hline $\mathrm{C06}$ & $130 \mathrm{C} 007$ & $0.0-0.5$ & -- & $0.46(\mathrm{~J})$ \\
\hline $\mathrm{C} 07$ & $130 \mathrm{C008}$ & $0.0-0.5$ & -- & $0.21(\mathrm{~J})$ \\
\hline $\mathrm{C} 08$ & $130 C 009$ & $6.5-7.0$ & -- & $0.23(\mathrm{~J})$ \\
\hline C09 & $130 c 010$ & $8.0-8.5$ & -- & $0.23(\mathrm{~J})$ \\
\hline
\end{tabular}

-- = Not detected above MDCs.

$\mathrm{J}=$ Estimated value

\section{D.5.2.4 RCRA Metals}

Analytical results for RCRA metals in environmental samples collected at this CAS that were detected above MDCs are presented in Table D.5-5. No metals were detected at concentrations exceeding their PALs. The FALs were established at the PAL concentrations.

\section{D.5.2.5 Polychlorinated Biphenyls}

No PCBs were detected above MDCs at CAS 10-02-01. 
Table D.5-5

Sample Results for RCRA Metals Detected above MDCs at CAS 10-02-01, Underground Storage Tank

\begin{tabular}{|c|c|c|c|c|c|c|c|c|}
\hline \multirow[b]{2}{*}{$\begin{array}{l}\text { Sample } \\
\text { Location }\end{array}$} & \multirow[b]{2}{*}{$\begin{array}{l}\text { Sample } \\
\text { Number }\end{array}$} & \multirow[b]{2}{*}{$\begin{array}{c}\text { Depth } \\
\text { (ft bgs) }\end{array}$} & \multicolumn{6}{|c|}{ COPC (mg/kg) } \\
\hline & & & 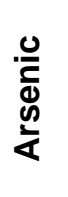 & 占 & 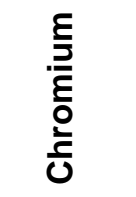 & శ్తి & 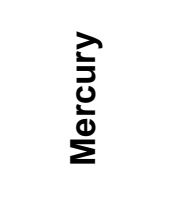 & $\frac{\xi}{\frac{\delta}{\partial}}$ \\
\hline \multicolumn{3}{|c|}{ FALs } & 23 & 67,000 & 450 & 800 & 310 & 5,100 \\
\hline $\mathrm{C01}$ & $130 C 001$ & $0.0-0.5$ & 2.6 & 110 & $3.8(\mathrm{~J}+)$ & 11 & $0.019(\mathrm{~J}-)$ & -- \\
\hline $\mathrm{C} 02$ & $130 \mathrm{C} 002$ & $0.0-0.5$ & 3.4 & 130 & $4.4(\mathrm{~J}+)$ & 15 & $0.013(\mathrm{~J}-)$ & $0.65(\mathrm{~J}+)$ \\
\hline \multirow{2}{*}{$\mathrm{CO3}$} & $130 \mathrm{C003}$ & $0.0-0.5$ & 2.6 & 120 & $3.6(\mathrm{~J}+)$ & 10 & $0.0095(\mathrm{~J}-)$ & -- \\
\hline & $130 C 004$ & $0.0-0.5$ & 2.7 & 120 & $4.5(\mathrm{~J}+)$ & 12 & 0.015 & -- \\
\hline $\mathrm{CO4}$ & $130 C 005$ & $0.0-0.5$ & 2.8 & 130 & $3.6(\mathrm{~J}+)$ & 11 & $0.021(\mathrm{~J}-)$ & -- \\
\hline $\mathrm{C} 05$ & $130 \mathrm{C} 006$ & $0.0-0.5$ & 3.2 & 110 & $4.1(\mathrm{~J}+)$ & 11 & $0.014(\mathrm{~J}-)$ & -- \\
\hline $\mathrm{C} 06$ & $130 C 007$ & $0.0-0.5$ & 2.8 & 130 & $4(\mathrm{~J}+)$ & 9.6 & $0.009(\mathrm{~J}-)$ & -- \\
\hline $\mathrm{C} 07$ & $130 \mathrm{C008}$ & $0.0-0.5$ & 3 & 130 & $4.4(\mathrm{~J}+)$ & 19 & $0.014(\mathrm{~J}-)$ & $0.68(\mathrm{~J}+)$ \\
\hline $\mathrm{C08}$ & $130 C 009$ & $6.5-7.0$ & 2.3 & 140 & $3.6(\mathrm{~J}+)$ & 10 & 0.0046 (J-) & -- \\
\hline C09 & $130 C 010$ & $8.0-8.5$ & 2.8 & 150 & $3.5(\mathrm{~J}+)$ & 10 & 0.0045 (J-) & -- \\
\hline
\end{tabular}

$--=$ Not detected above MDCs.

$\mathrm{J}+=$ The result is an estimated quantity, but the result may be biased high.

$\mathrm{J}-=$ The result is an estimated quantity, but the result may be biased low.

\section{D.5.2.6 Gamma-Emitting Radionuclides}

Analytical results for gamma-emitting radionuclides in environmental samples collected at this CAS that were detected above MDCs are presented in Table D.5-6. The radionuclide Am-241 was detected at concentrations that exceeded the PALs in three surface soil samples. The radionuclide Cs-137 was detected at concentrations that exceeded the PALs in five surface soil samples. The radionuclides were moved to the Tier II evaluation in which the Residual Radioactive (RESRAD) code was used to determine the site-specific FAL for these radionuclides. Americium-241 and Cs-137 did not exceed the FALs of $462 \mathrm{pCi} / \mathrm{g}$ and $92.5 \mathrm{pCi} / \mathrm{g}$, respectively, and therefore are not considered COCs at this CAS. The calculations of the FAL for Am-241 and Cs-137 are presented in Section 5.0 of Attachment 1. All other gamma-emitting results the FALs were established at the PAL concentrations. 
Table D.5-6

\section{Sample Results for Gamma-Emitting Radionuclides Detected above MDCs at CAS 10-02-01, Underground Storage Tank}

\begin{tabular}{|c|c|c|c|c|c|c|c|c|c|}
\hline \multirow{2}{*}{$\begin{array}{l}\text { Sample } \\
\text { Location }\end{array}$} & \multirow{2}{*}{$\begin{array}{l}\text { Sample } \\
\text { Number }\end{array}$} & \multirow{2}{*}{$\begin{array}{l}\text { Depth } \\
\text { (ft bgs) }\end{array}$} & \multicolumn{7}{|c|}{ COPC (pCi/g) } \\
\hline & & & Ac-228 & Am-241 & Cs-137 & Co-60 & $\mathrm{Pb}-212$ & $\mathrm{~Pb}-214$ & TI-208 \\
\hline \multicolumn{3}{|c|}{ FALs } & 5 & 462 & 92.5 & 2.68 & 5 & 5 & 5 \\
\hline $\mathrm{C01}$ & $130 \mathrm{C} 001$ & $0.0-0.5$ & 1.14 & $19.5(\mathrm{~J})$ & 36.5 & 0.59 & $1.72(\mathrm{~J})$ & $0.96(\mathrm{~J})$ & 0.45 \\
\hline $\mathrm{CO} 2$ & $130 \mathrm{C} 002$ & $0.0-0.5$ & 1.42 & $6.05(\mathrm{~J})$ & 14.4 & -- & $1.66(\mathrm{~J})$ & $0.97(\mathrm{~J})$ & 0.59 \\
\hline \multirow{2}{*}{$\mathrm{CO3}$} & $130 C 003$ & $0.0-0.5$ & 1.25 & $2.6(\mathrm{~J})$ & 8.10 & -- & $1.83(\mathrm{~J})$ & $0.9(\mathrm{~J})$ & 0.57 \\
\hline & $130 C 004$ & $0.0-0.5$ & 1.41 & $2.83(\mathrm{~J})$ & 8.50 & -- & $1.62(\mathrm{~J})$ & $1.04(\mathrm{~J})$ & 0.61 \\
\hline C04 & $130 C 005$ & $0.0-0.5$ & 1.64 & $14.7(\mathrm{~J})$ & 23.6 & 0.33 & $1.74(\mathrm{~J})$ & $1.08(\mathrm{~J})$ & 0.60 \\
\hline C05 & $130 \mathrm{C} 006$ & $0.0-0.5$ & 1.38 & $24.9(\mathrm{~J})$ & 40.1 & 0.69 & $1.84(\mathrm{~J})$ & $1.03(\mathrm{~J})$ & 0.51 \\
\hline C06 & $130 C 007$ & $0.0-0.5$ & 1.61 & $10.9(\mathrm{~J})$ & 19.1 & 0.35 & $1.75(\mathrm{~J})$ & $1.22(\mathrm{~J})$ & 0.48 \\
\hline $\mathrm{C} 07$ & $130 C 008$ & $0.0-0.5$ & 1.34 & $10.4(\mathrm{~J})$ & 17.2 & 0.30 & $1.97(\mathrm{~J})$ & $1.13(\mathrm{~J})$ & 0.46 \\
\hline C08 & $130 C 009$ & $6.5-7.0$ & 1.51 & -- & 0.98 & -- & $1.87(\mathrm{~J})$ & $1.05(\mathrm{~J})$ & 0.48 \\
\hline C09 & $130 \mathrm{C} 010$ & $8.0-8.5$ & 1.93 & $1.1(\mathrm{~J})$ & 1.75 & -- & 1.65 (J) & 1.07 (J) & 0.70 \\
\hline
\end{tabular}

Co $=$ Cobalt

$--=$ Not detected above MDCs.

$\mathrm{J}=$ Estimated value

\section{D.5.3 Nature and Extent of Contamination}

Based on the results of the CAI including the analytical results for environmental samples collected, there are no COCs at CAS 10-02-01.

\section{D.5.4 Revised Conceptual Site Model}

The CSM for CAS 10-02-01 modeled a potential UST. Even though the CSM was developed based on the potential presence of a UST, the structure of a bunker was modeled. The SAFER Plan requirements were met at this CAS, and no revisions were necessary to the CSM. 


\section{D.6.0 CAS 20-02-03, Underground Storage Tank, Investigation Results}

Corrective Action Site 20-02-03 is located in Area 20, north of the U20az (Barnwell) crater and west of the U20az post-test cellar (Figure D.1-1). This CAS was the site for post-test gas sampling activities. Several components were identified in the SAFER Plan for investigation, including the location of a potential UST identified the engineering drawings and a geophysical anomaly. The images in Figure D.6-1 reflect the sample points and CAS 20-02-03 before, during, and after investigation activities. Additional history and process knowledge is provided in the SAFER Plan (NNSA/NSO, 2008).

\section{D.6.1 SAFER Activities}

The SAFER Plan CAI included the investigation of a potential UST. The investigation determined no UST and the anomaly was two t-posts. A total of one characterization sample (including one FD) was collected during investigation activities at CAS 20-02-03. The sample ID, location, type, and analyses are listed in Table D.6-1. The specific CAI activities conducted to satisfy the SAFER Plan requirements at this CAS are described in the following sections.

\section{D.6.1.1 Field Screening}

Investigation samples were field screened for alpha and beta/gamma radiation, and gamma radiation. The FSRs were compared to FSLs to guide subsequent sampling decisions where appropriate. Field screening radiological FSLs were not exceeded in any samples.

\section{D.6.1.2 Geophysical Results}

The geophysical survey conducted at CAS 20-02-03 identified an anomaly that was considered the geometric configuration of a 250-gal UST. The excavation determined the anomaly to be t-posts. 


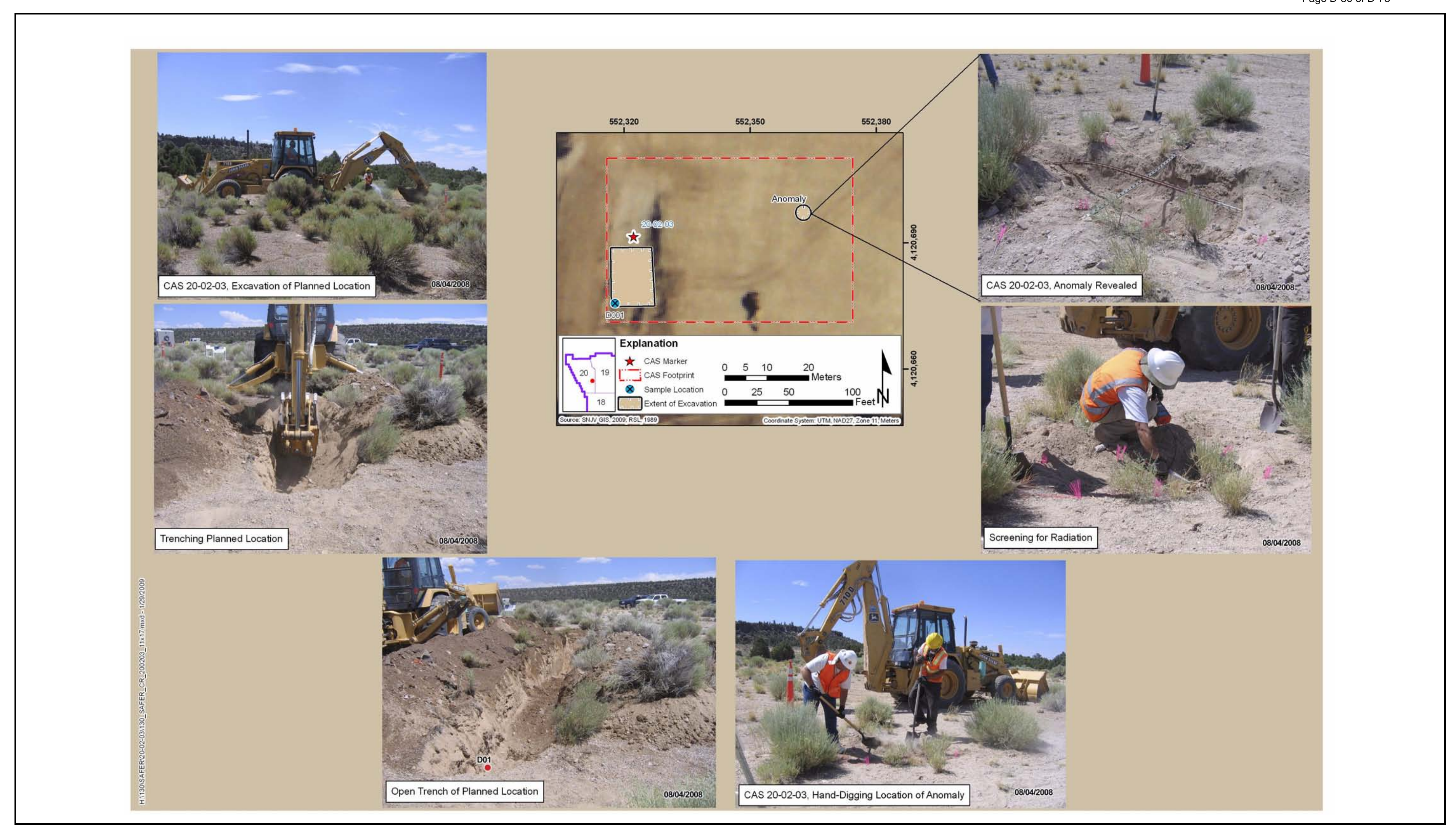

Figure D.6-1

Investigation Activities at CAS 20-02-03, Underground Storage Tank 


\section{D.6.1.3 Radiological Surveys}

An aerial radiological survey was conducted in 1999 of the NTS including the area of CAS 20-02-03, and a walkover survey was performed in 1997. The surveys determined the radiation levels to be indistinguishable from background (IT, 1997).

\section{D.6.1.4 Visual Inspections}

There was no visible staining or other biasing factors identified at CAS 20-02-03.

Table D.6-1

Samples Collected at CAS 20-02-03, Underground Storage Tank

\begin{tabular}{|c|c|c|c|c|c|c|c|c|c|c|}
\hline $\begin{array}{l}\text { Sample } \\
\text { Location }\end{array}$ & $\begin{array}{l}\text { Sample } \\
\text { Number }\end{array}$ & $\begin{array}{l}\text { Depth } \\
\text { (ft bgs) }\end{array}$ & Matrix & Purpose & $\begin{array}{l}\text { 음 } \\
\text { \& }\end{array}$ & 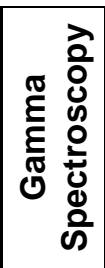 & 总 & 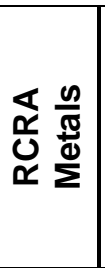 & $\begin{array}{l}\text { Uू } \\
\text { के }\end{array}$ & 仓̊ \\
\hline \multirow{2}{*}{ D01 } & 130D001 & $2.0-2.5$ & Soil & Environmental & $x$ & $x$ & $x$ & $x$ & $x$ & $x$ \\
\hline & 130D002 & $2.0-2.5$ & Soil & FD of \#130D001 & $x$ & $x$ & $x$ & $x$ & $x$ & $x$ \\
\hline NA & 130D301 & $\mathrm{NA}$ & Water & Trip Blank & -- & -- & -- & -- & -- & $x$ \\
\hline $\mathrm{NA}$ & 130D302 & $\mathrm{NA}$ & Water & Field Blank & $\bar{x}$ & $x$ & $\bar{x}$ & $x$ & $x$ & $x$ \\
\hline
\end{tabular}

-- = Not required

\section{D.6.1.5 Video Surveys}

No video surveys were conducted at CAS 20-02-03.

\section{D.6.1.6 Sample Collection}

Decision I environmental sampling activities included the collection of a subsurface soil sample at the native soil interface in the planned placement area of the UST according to the engineering drawings (Figure D.3-1). No samples were collected associated with a UST as none was found during the CAI. There were no samples collected at the geophysical anomaly as t-posts were discovered with no warranted biasing factors. 


\section{D.6.1.7 Deviations}

Investigation samples were collected as outlined in the SAFER Plan and submitted for laboratory analysis. There were no deviations from the SAFER Plan because the investigation did not find any UST or other bias.

\section{D.6.2 Investigation Results}

The following sections provide analytical results from the samples collected to complete investigation activities as outlined in the SAFER Plan. Investigation samples were analyzed for the SAFER Plan-specified COPCs, which included VOCs, SVOCs, TPH-DRO, TPH-GRO, RCRA metals, and gamma-emitting radionuclides. The analytical parameters and laboratory methods used to analyze the investigation samples are listed in Table D.2-2. Table D.6-1 lists the sample-specific analytical suite for CAS 20-02-03.

Analytical results from the environmental samples with concentrations exceeding MDCs are summarized in the following sections. An evaluation was conducted on all contaminants detected above MDCs by comparing individual concentration or activity results against the FALs. Establishment of the FALs is presented in Section H.1.0. The FALs were established as the corresponding PAL concentrations or activities if the contaminant concentrations were below their respective PALs.

\section{D.6.2.1 Volatile Organic Compounds}

No VOCs were detected above MDCs at CAS 20-02-03. The FALs were established at the PAL concentrations.

\section{D.6.2.2 Semivolatile Organic Compounds}

No SVOCs were detected above MDCs at CAS 20-02-03. The FALs were established at the PAL concentrations. 


\section{D.6.2.3 Total Petroleum Hydrocarbons}

Analytical results for TPH-DRO in soil samples collected at this CAS that were detected above MDCs are presented in Table D.6-2. There were no detects of TPH-GRO in samples collected at this CAS. No TPH-DRO was detected at concentrations exceeding the $100 \mathrm{mg} / \mathrm{kg}$ PAL. The FALs were established at the PAL concentrations.

Table D.6-2

Sample Results for TPH-DRO Detected above MDCs at CAS 20-02-03, Underground Storage Tank

\begin{tabular}{|c|c|c|c|}
\hline \multirow{2}{*}{$\begin{array}{c}\text { Sample } \\
\text { Location }\end{array}$} & \multirow{2}{*}{$\begin{array}{c}\text { Sample } \\
\text { Number }\end{array}$} & $\begin{array}{c}\text { Depth } \\
\text { (ft bgs) }\end{array}$ & COPC (mg/kg) \\
\cline { 4 - 4 } & & & DRO \\
\hline \multicolumn{3}{|c|}{ FAL } & $\mathbf{1 0 0}$ \\
\hline \hline D01 & $130 D 002$ & $2.0-2.5$ & $3.2(\mathrm{~J})$ \\
\hline
\end{tabular}

$\mathrm{J}=$ Estimated value

\section{D.6.2.4 RCRA Metals}

Analytical results for RCRA metals in environmental samples collected at this CAS that were detected above MDCs are presented in Table D.6-3. No metals were detected at concentrations exceeding their PALs. The FALs were established at the PAL concentrations.

Table D.6-3

Sample Results for RCRA Metals Detected above MDCs at CAS 20-02-03, Underground Storage Tank

\begin{tabular}{|c|c|c|c|c|c|c|c|c|}
\hline \multirow[b]{2}{*}{$\begin{array}{l}\text { Sample } \\
\text { Location }\end{array}$} & \multirow[b]{2}{*}{$\begin{array}{l}\text { Sample } \\
\text { Number }\end{array}$} & \multirow[b]{2}{*}{$\begin{array}{c}\text { Depth } \\
\text { (ft bgs) }\end{array}$} & \multicolumn{6}{|c|}{ COPC (mg/kg) } \\
\hline & & & 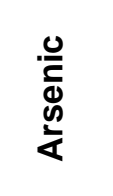 & 疍 & 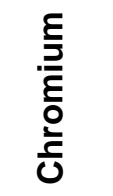 & ב্] & $\begin{array}{l}\stackrel{\gtrsim}{J} \\
\frac{0}{d} \\
\sum\end{array}$ & 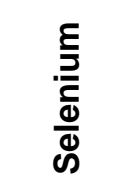 \\
\hline \multicolumn{3}{|c|}{ FALs } & 23 & 67,000 & 450 & 800 & 310 & 5,100 \\
\hline \multirow{2}{*}{ D01 } & 130D001 & $2.0-2.5$ & $3.3(\mathrm{~J})$ & 220 & $5.5(\mathrm{~J})$ & 10 & $0.024(\mathrm{~J}-)$ & -- \\
\hline & 130D002 & $2.0-2.5$ & $3.9(\mathrm{~J})$ & 200 & $5.6(\mathrm{~J})$ & 10 & $0.025(\mathrm{~J}-)$ & $0.71(\mathrm{~J}+)$ \\
\hline
\end{tabular}

-- = Not detected above MDCs

$\mathrm{J}=$ Estimated value

$\mathrm{J}+=$ The result is an estimated quantity, but the result may be biased high.

$\mathrm{J}-\mathrm{=}$ The result is an estimated quantity, but the result may be biased low. 


\section{D.6.2.5 Gamma-Emitting Radionuclides}

Analytical results for gamma-emitting radionuclides in environmental samples collected at this CAS that were detected above MDCs are presented in Table D.6-4. No gamma-emitting radionuclides were detected at concentrations exceeding their PALs. Because the gamma-emitting radionuclides were less than the PAL, no further isotopic analysis was necessary. The FALs were established at the PAL concentrations.

Table D.6-4

Sample Results for Gamma-Emitting Radionuclides Detected above MDCs at CAS 20-02-03, Underground Storage Tank

\begin{tabular}{|c|c|c|c|c|c|c|c|}
\hline \multirow{2}{*}{$\begin{array}{c}\text { Sample } \\
\text { Location }\end{array}$} & \multirow{2}{*}{$\begin{array}{c}\text { Sample } \\
\text { Number }\end{array}$} & \multirow{2}{*}{$\begin{array}{c}\text { Depth } \\
\text { (ft bgs) }\end{array}$} & \multicolumn{5}{c|}{ COPC (pCi/g) } \\
\cline { 4 - 8 } & & & Ac-228 & Pb-212 & Pb-214 & Tl-208 & Th-234 \\
\hline \multicolumn{3}{|c|}{ FALs } & $\mathbf{5}$ & $\mathbf{5}$ & $\mathbf{5}$ & $\mathbf{5}$ & 105 \\
\hline \hline \multirow{2}{*}{ D01 } & $130 \mathrm{D} 001$ & $2.0-2.5$ & 2.55 & $2.66(\mathrm{~J})$ & $1.65(\mathrm{~J})$ & 0.8 & $3.23(\mathrm{~J})$ \\
\cline { 2 - 8 } & $130 \mathrm{D} 002$ & $2.0-2.5$ & 2.81 & $2.99(\mathrm{~J})$ & $1.76(\mathrm{~J})$ & 0.95 & $3.33(\mathrm{~J})$ \\
\hline
\end{tabular}

Th $=$ Thorium

$\mathrm{J}=$ Estimated value

\section{D.6.3 Nature and Extent of Contamination}

Based on the results of the CAI including the analytical results for environmental samples collected, there are no COCs at CAS 20-02-03.

\section{D.6.4 Revised Conceptual Site Model}

The CSM for CAS 20-02-03 modeled a potential UST. Because no UST was found, the SAFER Plan requirements were met at this CAS, and no revisions were necessary to the CSM. 


\section{D.7.0 CAS 20-99-05, Tar Residue, Investigation Results}

Corrective Action Site 20-99-05 is located in Area 20 approximately $500 \mathrm{ft}$ south of the U20z potential crater from the Kasseri underground nuclear test (Figure D.1-1). This site consisted of hardened, lightweight tar residue in small discontinuous piles encompassing an approximate 30-by-40-ft area. Several components were identified in the SAFER Plan for investigation, including the direct sampling of the tar, environmental soil samples beneath the tar, and cleanup of the tar. The images in Figure D.7-1 reflect the sample points and CAS 20-99-05 before, during, and after investigation activities. Additional history and process knowledge is provided in the SAFER Plan (NNSA/NSO, 2008).

\section{D.7.1 SAFER Activities}

The SAFER Plan CAI included the investigation of tar residue. A total of three characterization samples (including one FD) were collected during investigation activities at CAS 20-99-05. The sample ID, location, type, and analyses are listed in Table D.7-1. The specific CAI activities conducted to satisfy the SAFER Plan requirements at this CAS are described in the following sections.

\section{D.7.1.1 Field Screening}

Investigation samples were field screened for alpha and beta/gamma radiation, and gamma radiation. The FSRs were compared to FSLs to guide subsequent sampling decisions where appropriate. Field screening radiological FSLs were not exceeded in any samples.

\section{D.7.1.2 Radiological Surveys}

An aerial radiological survey was conducted of the NTS including the area of CAS 20-99-05. The survey measured the terrestrial gamma radiation of natural and man-made radiation. This survey determined the radiation levels to be indistinguishable from background (IT, 1997).

\section{D.7.1.3 Visual Inspections}

There was visible staining on the soil as a result of the tar residue at CAS 20-99-05. 




Figure D.7-1

Investigation Activities at CAS 20-99-05, Tar Residue 
Table D.7-1

\section{Samples Collected at CAS 20-99-05, Tar Residue}

\begin{tabular}{|c|c|c|c|c|c|c|c|c|c|c|c|c|c|c|c|c|c|}
\hline \multirow{2}{*}{ E02 } & 130E002 & $0.0-0.5$ & Soil & Environmental & $x$ & -- & -- & $x$ & -- & -- & -- & $x$ & -- & -- & -- & -- & $x$ \\
\hline & 130E003 & $0.0-0.5$ & Soil & FD of \#130E002 & $x$ & -- & -- & $x$ & -- & -- & -- & $x$ & -- & -- & -- & -- & $x$ \\
\hline $\mathrm{N} / \mathrm{A}$ & 130E301 & $\mathrm{N} / \mathrm{A}$ & Water & Trip Blank & -- & -- & -- & -- & -- & -- & -- & -- & -- & -- & -- & -- & $x$ \\
\hline E02 & 130E502 & N/A & Solid & $\begin{array}{c}\text { Waste } \\
\text { Management }\end{array}$ & $X$ & $\mathrm{X}$ & $X$ & -- & $x$ & $\mathrm{X}$ & $X$ & -- & $X$ & $x$ & $X$ & $X$ & -- \\
\hline
\end{tabular}

-- = Not required

\section{D.7.1.4 Video Surveys}

No video surveys were conducted at CAS 20-99-05.

\section{D.7.1.5 Sample Collection}

Decision I environmental sampling activities included the collection of surface soil samples below two biased tar residue locations to determine whether the tar residue had impacted the environmental media (Figure D.7-1). Two bias samples of the tar residue were collected for waste management determination.

\section{D.7.1.6 Deviations}

Investigation samples were collected as outlined in the SAFER Plan and submitted for laboratory analysis. There were no deviations from the SAFER Plan. 


\section{D.7.2 Investigation Results}

The following sections provide analytical results from the samples collected to complete investigation activities as outlined in the SAFER Plan. Investigation samples were analyzed for the SAFER Plan-specified COPCs, which included VOCs, SVOCs, TPH-DRO, and RCRA metals. The analytical parameters and laboratory methods used to analyze the investigation samples are listed in Table D.2-2. Table D.7-1 lists the sample-specific analytical suite for CAS 20-99-05.

Analytical results from the environmental samples with concentrations exceeding MDCs are summarized in the following sections. An evaluation was conducted on all contaminants detected above MDCs by comparing individual concentration or activity results against the FALs. Establishment of the FALs is presented in Section H.1.0. The FALs were established as the corresponding PAL concentrations or activities if the contaminant concentrations were below their respective PALs.

\section{D.7.2.1 Volatile Organic Compounds}

No VOCs were detected above MDCs at CAS 20-99-05. The FALs were established at the PAL concentrations.

\section{D.7.2.2 Semivolatile Organic Compounds}

Analytical results for SVOCs in environmental samples collected at this CAS that were detected above MDCs are presented in Table D.7-2. No SVOCs were detected at concentrations exceeding the respective PALs. The FALs were established at the PAL concentrations.

\section{D.7.2.3 Total Petroleum Hydrocarbons}

Analytical results for TPH-DRO in soil samples collected at this CAS that were detected above MDCs are presented in Table D.7-3. No TPH-DRO was detected at concentrations exceeding the $100 \mathrm{mg} / \mathrm{kg}$ PAL. The FALs were established at the PAL concentrations. 
Table D.7-2

Sample Results for Total SVOCs Detected above MDCs at CAS 20-99-05, Tar Residue

\begin{tabular}{|c|c|c|c|c|c|c|}
\hline \multirow[b]{2}{*}{$\begin{array}{c}\text { Sample } \\
\text { Location }\end{array}$} & \multirow[b]{2}{*}{$\begin{array}{l}\text { Sample } \\
\text { Number }\end{array}$} & \multirow[b]{2}{*}{$\begin{array}{l}\text { Depth } \\
\text { (ft bgs) }\end{array}$} & \multicolumn{4}{|c|}{ COPC (mg/kg) } \\
\hline & & & 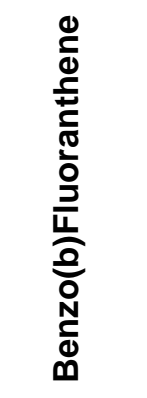 & 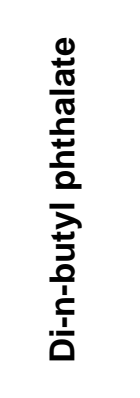 & 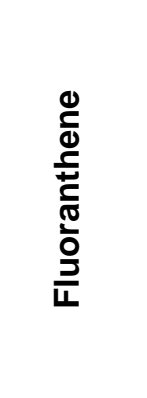 & 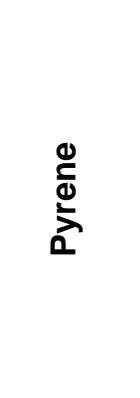 \\
\hline \multicolumn{3}{|c|}{ FALs } & 2.1 & 62,000 & 22,000 & 29,000 \\
\hline E01 & 130E001 & $0.0-0.5$ & $0.089(\mathrm{~J})$ & $0.18(\mathrm{~J})$ & $0.091(\mathrm{~J})$ & $0.079(\mathrm{~J})$ \\
\hline \multirow{2}{*}{ E02 } & 130E002 & $0.0-0.5$ & -- & $0.086(\mathrm{~J})$ & -- & -- \\
\hline & 130E003 & $0.0-0.5$ & $\overline{--}$ & $0.13(\mathrm{~J})$ & -- & - \\
\hline
\end{tabular}

$--=$ Not detected above MDCs.

$\mathrm{J}=$ Estimated value

Table D.7-3

Sample Results for TPH-DRO Detected above MDCs at CAS 20-99-05, Tar Residue

\begin{tabular}{|c|c|c|c|}
\hline \multirow{2}{*}{$\begin{array}{c}\text { Sample } \\
\text { Location }\end{array}$} & \multirow{2}{*}{$\begin{array}{c}\text { Sample } \\
\text { Number }\end{array}$} & \multirow{2}{*}{$\begin{array}{c}\text { Depth } \\
\text { (ft bgs) }\end{array}$} & COPC (mg/kg) \\
\cline { 4 - 4 } & & & $\mathbf{1 0 0}$ \\
\hline \multicolumn{3}{|c|}{ FAL } & $3.5(\mathrm{~J})$ \\
\hline \hline E01 & $130 E 001$ & $0.0-0.5$ & DRO \\
\hline
\end{tabular}

$\mathrm{J}=$ Estimated value

\section{D.7.2.4 RCRA Metals}

Analytical results for RCRA metals in environmental samples collected at this CAS that were detected above MDCs are presented in Table D.7-4. No metals were detected at concentrations exceeding their PALs. The FALs were established at the PAL concentrations. 
Table D.7-4

Sample Results for RCRA Metals Detected above MDCs at CAS 20-99-05, Tar Residue

\begin{tabular}{|c|c|c|c|c|c|c|c|c|}
\hline \multirow[b]{2}{*}{$\begin{array}{l}\text { Sample } \\
\text { Location }\end{array}$} & \multirow[b]{2}{*}{$\begin{array}{l}\text { Sample } \\
\text { Number }\end{array}$} & \multirow[b]{2}{*}{$\begin{array}{l}\text { Depth } \\
\text { (ft bgs) }\end{array}$} & \multicolumn{6}{|c|}{ COPC (mg/kg) } \\
\hline & & & 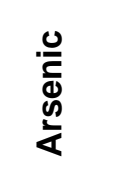 & 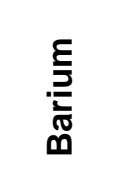 & 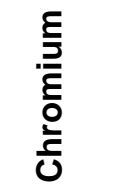 & ఫ్ర & 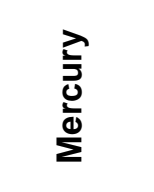 & $\begin{array}{l}\frac{E}{J} \\
\frac{\bar{J}}{\mathbb{d}} \\
\mathcal{S}\end{array}$ \\
\hline \multicolumn{3}{|c|}{ FALs } & 23 & 67,000 & 450 & 800 & 310 & 5,100 \\
\hline E01 & 130E001 & $0.0-0.5$ & $3.5(\mathrm{~J})$ & 130 & $8(\mathrm{~J})$ & 11 & $0.019(\mathrm{~J}-)$ & $0.8(\mathrm{~J}+)$ \\
\hline \multirow{2}{*}{ E02 } & 130E002 & $0.0-0.5$ & $3.4(\mathrm{~J})$ & 130 & $7.9(\mathrm{~J})$ & 10 & $0.014(\mathrm{~J}-)$ & $0.96(\mathrm{~J}+)$ \\
\hline & 130E003 & $0.0-0.5$ & $3.2(\mathrm{~J})$ & 120 & $7.3(\mathrm{~J})$ & 9.4 & $0.019(\mathrm{~J}-)$ & $0.86(\mathrm{~J}+)$ \\
\hline
\end{tabular}

$\mathrm{J}=$ Estimated value

$\mathrm{J}+=$ The result is an estimated quantity, but the result may be biased high.

$\mathrm{J}-\mathrm{=}$ The result is an estimated quantity, but the result may be biased low.

\section{D.7.3 Nature and Extent of Contamination}

Based on the results of the CAI including the analytical results for environmental samples collected, there are no COCs at CAS 20-99-05.

\section{D.7.4 Revised Conceptual Site Model}

The SAFER Plan requirements were met at this CAS, and no revisions were necessary to the CSM. 


\section{D.8.0 CAS 22-02-02, Buried UST Piping, Investigation Results}

Corrective Action Site 22-02-02 is located in Area 22 at the former Camp Desert Rock

(Figure D.1-1). This CAS has remnants of a former gas station that include a concrete island; a concrete foundation (Building T-951), which may have been the control flow room; and buried distribution piping that has been removed. Several components were identified in the SAFER Plan for investigation, including the excavation and removal of the buried piping and the backfilling of the foundation. The images in Figure D.8-1 reflect the sample points and CAS 22-02-02 before, during, and after investigation activities. Additional history and process knowledge is provided in the SAFER Plan (NNSA/NSO, 2008).

\section{D.8.1 SAFER Activities}

The CSM for CAS 22-02-02 modeled buried UST piping, the concrete island, and the foundation. A total of four characterization samples (including one FD) were collected during investigation activities at CAS 22-02-02. The sample ID, location, type, and analyses are listed in Table D.8-1. The specific CAI activities conducted to satisfy the SAFER Plan requirements at this CAS are described in the following sections.

\section{D.8.1.1 Field Screening}

Investigation samples were field screened for alpha and beta/gamma radiation, and gamma radiation. The FSRs were compared to FSLs to guide subsequent sampling decisions where appropriate. Field screening radiological FSLs were not exceeded in any samples.

\section{D.8.1.2 Geophysical Results}

The geophysical survey conducted at CAS 22-02-02 identified an anomaly consistent with buried metal from the concrete island to the former Building T-951. The excavation confirmed the presence of the buried UST piping. The piping and associated lines were removed, and soil samples were collected in accordance with the SAFER Plan. 


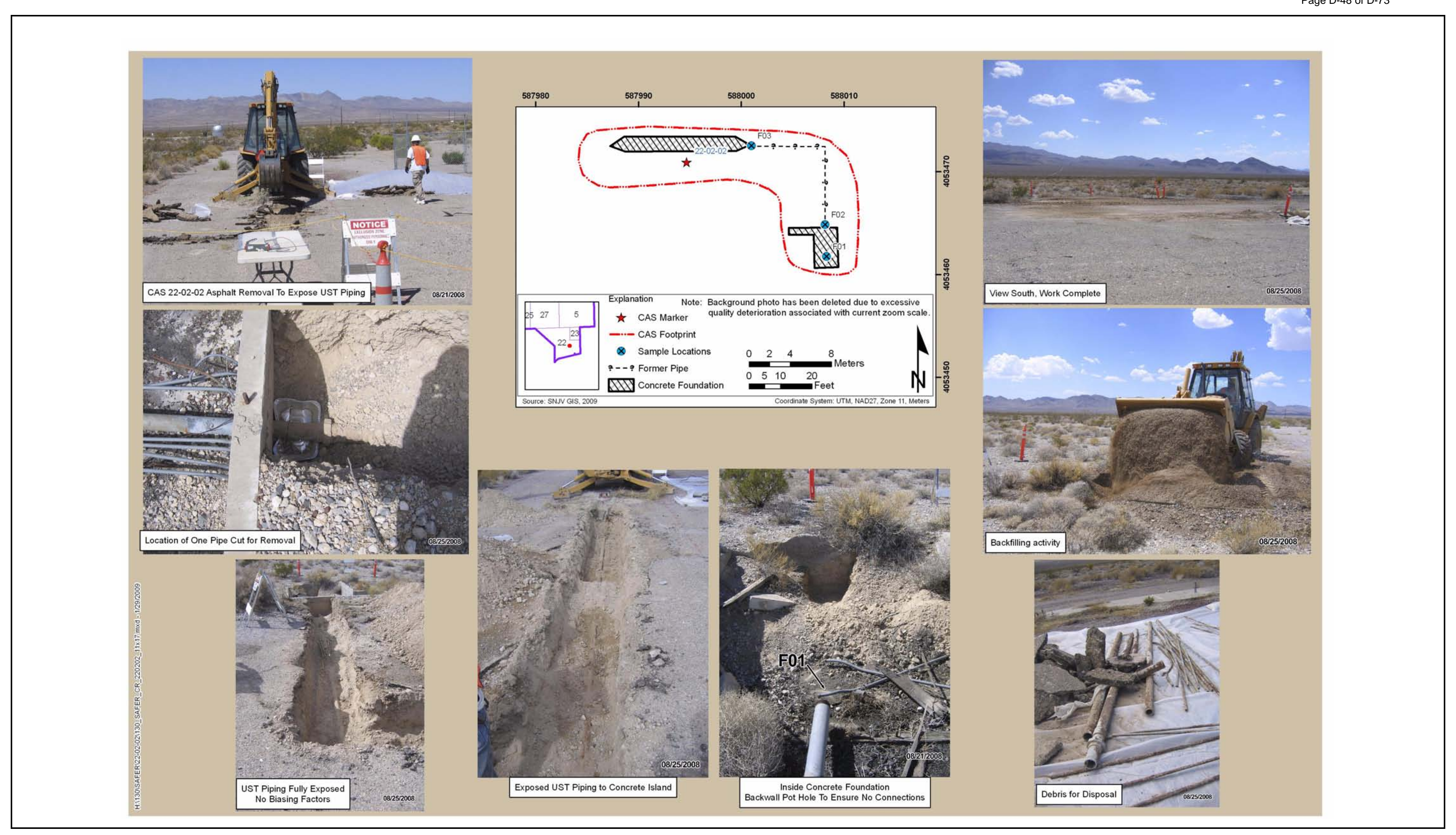

Figure D.8-1

Investigation Activities at CAS 22-02-02, Buried UST Piping 
Table D.8-1

Samples Collected at CAS 22-02-02, Buried UST Piping

\begin{tabular}{|c|c|c|c|c|c|c|c|c|c|c|}
\hline $\begin{array}{l}\text { Sample } \\
\text { Location }\end{array}$ & $\begin{array}{l}\text { Sample } \\
\text { Number }\end{array}$ & $\begin{array}{l}\text { Depth } \\
\text { (ft bgs) }\end{array}$ & Matrix & Purpose & $\begin{array}{l}\text { O } \\
\stackrel{\sim}{\Delta}\end{array}$ & 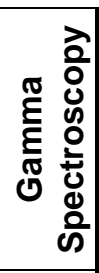 & 옹 & 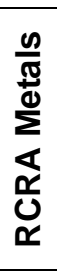 & 帒 & 仓̊ \\
\hline F01 & 130F001 & $0.0-0.5$ & Soil & Environmental & $x$ & $\bar{x}$ & $x$ & $\mathrm{X}$ & $\mathrm{X}$ & $\mathrm{X}$ \\
\hline \multirow{2}{*}{ F02 } & 130F002 & $2.0-2.5$ & Soil & Environmental & $x$ & $x$ & $x$ & $x$ & $x$ & $x$ \\
\hline & 130F003 & $2.0-2.5$ & Soil & FD of $\# 130 F 002$ & $x$ & $x$ & $x$ & $x$ & $x$ & $x$ \\
\hline F03 & 130F004 & $2.5-3.0$ & Soil & Environmental & $x$ & $x$ & $x$ & $x$ & $x$ & $x$ \\
\hline $\mathrm{N} / \mathrm{A}$ & 130F301 & $\mathrm{N} / \mathrm{A}$ & Water & Trip Blank & -- & -- & -- & -- & -- & $x$ \\
\hline N/A & 130F302 & $\mathrm{N} / \mathrm{A}$ & Water & Trip Blank & -- & -- & -- & -- & -- & $x$ \\
\hline $\mathrm{N} / \mathrm{A}$ & 130F303 & N/A & Water & Trip Blank & -- & -- & -- & -- & -- & $x$ \\
\hline N/A & 130F304 & $N / A$ & Water & Field Blank & $x$ & $x$ & $x$ & $x$ & $x$ & $x$ \\
\hline $\mathrm{N} / \mathrm{A}$ & 130F305 & $\mathrm{N} / \mathrm{A}$ & Water & Source Material, QC & $x$ & $x$ & $x$ & $x$ & $x$ & $x$ \\
\hline N/A & 130F306 & N/A & Water & Equipment Rinsate & $x$ & $x$ & $\mathrm{x}$ & $\mathrm{X}$ & $\mathrm{x}$ & $\mathrm{x}$ \\
\hline
\end{tabular}

-- = Not required

\section{D.8.1.3 Radiological Surveys}

A radiological survey was conducted of CAS 22-02-02. The survey measured the terrestrial gamma radiation of natural and man-made radiation. This survey determined the radiation levels to be indistinguishable from background levels (IT, 2002).

\section{D.8.1.4 Visual Inspections}

There was visible soil staining inside the concrete foundation (Building T-951). A surface soil sample of the stained soil was collected and submitted for laboratory analysis. No other biasing factors were identified at CAS 22-02-02.

\section{D.8.1.5 Video Surveys}

No video surveys were conducted at CAS 22-02-02. 


\section{D.8.1.6 Sample Collection}

Decision I environmental sampling activities included the collection of surface soil samples inside the concrete foundation below the open end of the distribution pipe (which included the staining). Subsurface soil samples also were collected under the distribution piping where it connected to the outside of the concrete foundation, and below the distribution piping where it connected to the concrete island (Figure D.8-1).

\section{D.8.1.7 Deviations}

Investigation samples were collected as outlined in the SAFER Plan and submitted for laboratory analysis. There were no deviations from the SAFER Plan.

\section{D.8.2 Investigation Results}

The following sections provide analytical results from the samples collected to complete investigation activities as outlined in the SAFER Plan. Investigation samples were analyzed for the SAFER Plan-specified COPCs, which included VOCs, SVOCs, TPH-DRO, TPH-GRO, RCRA metals, and gamma-emitting radionuclides. The analytical parameters and laboratory methods used to analyze the investigation samples are listed in Table D.2-2. Table D.8-1 lists the sample-specific analytical suite for CAS 22-02-02.

Analytical results from the environmental samples with concentrations exceeding MDCs are summarized in the following sections. An evaluation was conducted on all contaminants detected above MDCs by comparing individual concentrations or activity results against the FALs. Establishment of the FALs is presented in Section H.1.0. The FALs were established as the corresponding PAL concentrations or activities if the contaminant concentrations were below their respective PALs.

\section{D.8.2.1 Volatile Organic Compounds}

Analytical results for VOCs in environmental samples collected at this CAS that were detected above MDCs are presented in Table D.8-2. No VOCs were detected at concentrations exceeding their respective PALs. The FALs were established at the PAL concentrations. 
Table D.8-2

Sample Results for Total VOCs Detected above MDCs at CAS 22-02-02, Buried UST Piping

\begin{tabular}{|c|c|c|c|c|}
\hline \multirow{2}{*}{$\begin{array}{l}\text { Sample } \\
\text { Location }\end{array}$} & \multirow{2}{*}{$\begin{array}{c}\text { Sample } \\
\text { Number }\end{array}$} & \multirow{2}{*}{$\begin{array}{c}\text { Depth } \\
\text { (ft bgs) }\end{array}$} & \multicolumn{2}{|c|}{ COPC (mg/kg) } \\
\hline & & & Acetone & Methylene Chloride \\
\hline \multicolumn{3}{|c|}{ FALs } & 54,000 & 21 \\
\hline F01 & 130F001 & $0.0-0.5$ & $0.019(\mathrm{~J})$ & $0.0028(\mathrm{~J})$ \\
\hline \multirow{2}{*}{ F02 } & 130F002 & $2.0-2.5$ & -- & $0.0022(\mathrm{~J})$ \\
\hline & 130F003 & $2.0-2.5$ & -- & $0.0023(\mathrm{~J})$ \\
\hline F03 & 130F004 & $2.5-3.0$ & -- & $0.002(\mathrm{~J})$ \\
\hline
\end{tabular}

$--=$ Not detected above MDCs.

$\mathrm{J}=$ Estimated value

\section{D.8.2.2 Semivolatile Organic Compounds}

Analytical results for SVOCs in environmental samples collected at this CAS that were detected above MDCs are presented in Table D.8-3. No SVOCs were detected at concentrations exceeding the respective PALs. The FALs were established at the PAL concentrations.

Table D.8-3

Sample Results for Total SVOCs Detected above MDCs at CAS 22-02-02, Buried UST Piping

\begin{tabular}{|c|c|c|c|}
\hline \multirow{2}{*}{$\begin{array}{c}\text { Sample } \\
\text { Location }\end{array}$} & \multirow{2}{*}{$\begin{array}{c}\text { Sample } \\
\text { Number }\end{array}$} & $\begin{array}{c}\text { Depth } \\
\text { (ft bgs) }\end{array}$ & COPC (mg/kg) \\
\cline { 4 - 4 } & & & Bis(2-ethylhexyl)Phthalate \\
\hline \multicolumn{3}{|c|}{ FAL } & $\mathbf{1 2 0}$ \\
\hline \hline F03 & $130 F 004$ & $2.5-3.0$ & 0.35 \\
\hline
\end{tabular}

\section{D.8.2.3 Total Petroleum Hydrocarbons}

Analytical results for TPH-DRO in soil samples collected at this CAS that were detected above MDCs are presented in Table D.8-4. No TPH-GRO was detected above MDCs or the respective PALs at CAS 22-02-02. The FALs were established at the PAL concentrations. 
Table D.8-4

\section{Sample Results for TPH-DRO Detected above MDCs at CAS 22-02-02, Buried UST Piping}

\begin{tabular}{|c|c|c|c|}
\hline \multirow{2}{*}{$\begin{array}{c}\text { Sample } \\
\text { Location }\end{array}$} & \multirow{2}{*}{$\begin{array}{c}\text { Sample } \\
\text { Number }\end{array}$} & $\begin{array}{c}\text { Depth } \\
\text { (ft bgs) }\end{array}$ & COPC (mg/kg) \\
\cline { 4 - 4 } & & & DRO \\
\hline \multicolumn{3}{|c|}{ FAL } & $\mathbf{1 0 0}$ \\
\hline \hline F01 & $130 F 001$ & $0.0-0.5$ & $2.3(\mathrm{~J})$ \\
\hline \multirow{2}{*}{ F02 } & $130 F 002$ & $2.0-2.5$ & 7.2 \\
\cline { 2 - 5 } & 130F003 & $2.0-2.5$ & 9 \\
\hline F03 & 130F004 & $2.5-3.0$ & 8.5 \\
\hline
\end{tabular}

$\mathrm{J}=$ Estimated value

\section{D.8.2.4 RCRA Metals}

Analytical results for RCRA metals in environmental samples collected at this CAS that were detected above MDCs are presented in Table D.8-5. No metals were detected at concentrations exceeding their PALs. The FALs were established at the PAL concentrations.

Table D.8-5

Sample Results for RCRA Metals Detected above MDCs at CAS 22-02-02, Buried UST Piping

\begin{tabular}{|c|c|c|c|c|c|c|c|c|}
\hline \multirow[b]{2}{*}{$\begin{array}{l}\text { Sample } \\
\text { Location }\end{array}$} & \multirow[b]{2}{*}{$\begin{array}{l}\text { Sample } \\
\text { Number }\end{array}$} & \multirow[b]{2}{*}{$\begin{array}{l}\text { Depth } \\
\text { (ft bgs) }\end{array}$} & \multicolumn{6}{|c|}{ COPC (mg/kg) } \\
\hline & & & $\begin{array}{l}\frac{0}{2} \\
\frac{D}{d} \\
\frac{\omega}{<} \\
\frac{\omega}{\alpha}\end{array}$ & 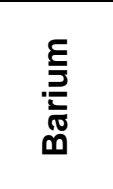 & 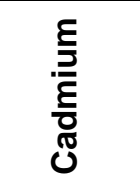 & 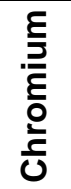 & శ్రి & 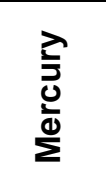 \\
\hline \multicolumn{3}{|c|}{ FALs } & 23 & 67,000 & 450 & 450 & 800 & 310 \\
\hline F01 & 130F001 & $0.0-0.5$ & $\overline{5.8}$ & 87 & $0.17(\mathrm{~J}-)$ & 5.7 & 12 & 0.015 \\
\hline \multirow{2}{*}{ F02 } & 130F002 & $2.0-2.5$ & 5.9 & 98 & $0.31(\mathrm{~J}-)$ & 5.2 & 110 & 0.01 \\
\hline & $130 \mathrm{~F} 003$ & $2.0-2.5$ & 6.3 & 89 & $0.35(\mathrm{~J}-)$ & 5.5 & 110 & 0.0082 \\
\hline F03 & 130F004 & $2.5-3.0$ & 4.8 & 82 & 0.35 & 4.6 & 10 & 0.011 \\
\hline
\end{tabular}

$\mathrm{J}-=$ The result is an estimated quantity, but the result may be biased low. 


\section{D.8.2.5 Gamma-Emitting Radionuclides}

Analytical results for gamma-emitting radionuclides in environmental samples collected at this CAS that were detected above MDCs are presented in Table D.8-6. No gamma-emitting radionuclides were detected at concentrations exceeding their PALs. Because the gamma-emitting radionuclides were less than the PAL, no further isotopic analysis was necessary. The FALs were established at the PAL concentrations.

Table D.8-6

Sample Results for Gamma-Emitting Radionuclides Detected above MDCs at CAS 22-02-02, Buried UST Piping

\begin{tabular}{|c|c|c|c|c|c|c|}
\hline \multirow{2}{*}{$\begin{array}{l}\text { Sample } \\
\text { Location }\end{array}$} & \multirow{2}{*}{$\begin{array}{l}\text { Sample } \\
\text { Number }\end{array}$} & \multirow{2}{*}{$\begin{array}{l}\text { Depth } \\
\text { (ft bgs) }\end{array}$} & \multicolumn{4}{|c|}{ COPC (pCi/g) } \\
\hline & & & \multirow{2}{*}{$\begin{array}{c}\text { Ac-228 } \\
5\end{array}$} & \multirow{2}{*}{$\begin{array}{c}\mathrm{Pb}-212 \\
5\end{array}$} & \multirow{2}{*}{$\frac{\mathrm{Pb}-214}{5}$} & \multirow{2}{*}{$\begin{array}{c}\text { TI-208 } \\
5\end{array}$} \\
\hline & FALs & & & & & \\
\hline F01 & 130F001 & $0.0-0.5$ & 0.76 & 0.79 & $0.69(\mathrm{~J})$ & 0.199 \\
\hline \multirow{2}{*}{ F02 } & 130F002 & $2.0-2.5$ & 0.99 & 0.82 & $0.58(\mathrm{~J})$ & 0.278 \\
\hline & 130F003 & $2.0-2.5$ & -- & 0.81 & $0.52(\mathrm{~J})$ & 0.242 \\
\hline F03 & 130F004 & $2.5-3.0$ & -- & 0.63 & $0.61(\mathrm{~J})$ & 0.282 \\
\hline
\end{tabular}

$--=$ Not detected above MDCs.

$\mathrm{J}=$ Estimated value

\section{D.8.3 Nature and Extent of Contamination}

Based on the results of the CAI including the analytical results for environmental samples collected, there are no COCs at CAS 22-02-02.

\section{D.8.4 Revised Conceptual Site Model}

The SAFER Plan requirements were met at this CAS, and no revisions were necessary to the CSM. 


\section{D.9.0 CAS 23-02-07, Underground Storage Tank, Investigation Results}

Corrective Action Site 23-02-07 is located in Area 23 at a former gas station (Figure D.1-1). This CAS is described as a waste oil tank that was registered as closed in place by NDEP. Several activities were identified in the SAFER Plan for investigation, including the excavation of the potential UST and, if present, the confirmation that the tank had been properly closed in place. The images in Figure D.9-1 reflect the sample points and CAS 23-02-07 before, during, and after investigation activities. Additional history and process knowledge is provided in the SAFER Plan (NNSA/NSO, 2008).

\section{D.9.1 SAFER Activities}

The CSM for CAS 23-02-07 modeled a potential closed UST. The investigation discovered the UST and found it to be closed as documented. The UST was excavated to determine whether there had been a release and the condition of the tank. A total of four characterization samples (including one FD) were collected during investigation activities at CAS 23-02-07. The sample ID, location, type, and analyses are listed in Table D.9-1. The specific CAI activities conducted to satisfy the SAFER Plan requirements at this CAS are described in the following sections.

\section{D.9.1.1 Field Screening}

Investigation samples were field screened for alpha and beta/gamma radiation, and gamma radiation. The FSRs were compared to FSLs to guide subsequent sampling decisions where appropriate. Field screening radiological FSLs were not exceeded in any samples.

\section{D.9.1.2 Radiological Surveys}

Because this CAS is located in Mercury, Nevada, an area not suspected to have been affected by nuclear testing, there was no radiological walkover surveys required or performed. 




Figure D.9-1

Investigation Activities at CAS 23-02-07, Underground Storage Tank 
Table D.9-1

Samples Collected at CAS 23-02-07, Underground Storage Tank

\begin{tabular}{|c|c|c|c|c|c|c|c|c|c|c|c|c|c|c|}
\hline $\begin{array}{l}\text { Sample } \\
\text { Location }\end{array}$ & $\begin{array}{l}\text { Sample } \\
\text { Number }\end{array}$ & $\begin{array}{l}\text { Depth } \\
\text { (ft bgs) }\end{array}$ & Matrix & Purpose & $\begin{array}{l}\text { 움 } \\
\stackrel{\leftrightarrow}{\Delta}\end{array}$ & 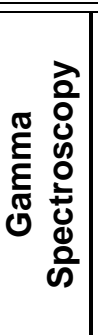 & $\begin{array}{l}\text { 옹 } \\
\text { i }\end{array}$ & 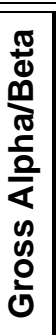 & 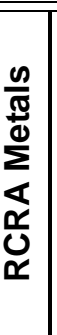 & 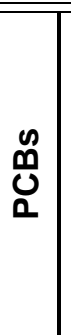 & 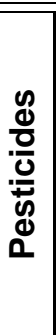 & $\begin{array}{l}0 \\
0 \\
0\end{array}$ & 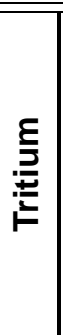 & 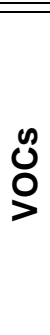 \\
\hline G01 & 130G001 & $1.5-2.0$ & Soil & Environmental & $x$ & $x$ & $x$ & -- & $\mathrm{x}$ & $x$ & $x$ & $x$ & \begin{tabular}{l|l}
-- & \\
\end{tabular} & $x$ \\
\hline \multirow{2}{*}{ G02 } & 130G002 & $7.5-8.0$ & Soil & Environmental & $x$ & $x$ & $x$ & -- & $x$ & $x$ & -- & $x$ & -- & $x$ \\
\hline & 130G003 & $7.5-8.0$ & Soil & FD of $\# 130 G 002$ & $x$ & $x$ & $x$ & -- & $\mathrm{x}$ & $x$ & -- & $\mathrm{x}$ & -- & $x$ \\
\hline G03 & 130G004 & $8.0-8.5$ & Soil & Environmental & $x$ & $x$ & $x$ & -- & $x$ & $x$ & -- & $x$ & -- & $x$ \\
\hline $\mathrm{N} / \mathrm{A}$ & 130G301 & $\mathrm{N} / \mathrm{A}$ & Water & Trip Blank & -- & -- & -- & -- & -- & -- & -- & -- & -- & $x$ \\
\hline N/A & 130G302 & N/A & Water & Field Blank & $x$ & $x$ & $x$ & -- & $x$ & $x$ & -- & $x$ & -- & $x$ \\
\hline $\mathrm{N} / \mathrm{A}$ & $130 \mathrm{G} 303$ & $N / A$ & Water & Trip Blank & -- & -- & -- & -- & -- & -- & -- & -- & -- & $x$ \\
\hline $\mathrm{N} / \mathrm{A}$ & $130 G 304$ & $\mathrm{~N} / \mathrm{A}$ & Water & Trip Blank & -- & -- & -- & -- & -- & -- & -- & -- & -- & $x$ \\
\hline $\mathrm{N} / \mathrm{A}$ & $130 G 305$ & $\mathrm{~N} / \mathrm{A}$ & Water & Trip Blank & -- & -- & -- & -- & -- & -- & -- & -- & -- & $x$ \\
\hline $\begin{array}{l}\text { Drum \#130 } \\
\text { G01 }\end{array}$ & 130G501 & $\mathrm{N} / \mathrm{A}$ & Liquid & $\begin{array}{c}\text { Waste } \\
\text { Management }\end{array}$ & $\mathrm{X}$ & -- & $x$ & $\mathrm{x}$ & $x$ & $x$ & -- & $x$ & $\mathrm{x}$ & $x$ \\
\hline
\end{tabular}

$--=$ Not required

\section{D.9.1.3 Visual Inspections}

There was one visible stain observed along the west wall of the investigation approximately $4 \mathrm{ft}$ away from the UST. A soil sample (130G001) was collected and submitted for laboratory analysis. The stickup from the UST was grouted, and no visible staining was observed. No other visible staining was observed during the CAI. No other biasing factors were identified at CAS 23-02-07.

\section{D.9.1.4 Video Surveys}

No video surveys were conducted at CAS 23-02-07.

\section{D.9.1.5 Sample Collection}

Decision I environmental sampling activities included the collection of a subsurface soil sample below each end of the UST and a subsurface soil sample of a stain discovered during excavation 
(Figure D.9-1). No other samples were collected around the tank. Visual confirmation showed that the tank had been grouted appropriately and surrounded with clean material.

\section{D.9.1.6 Deviations}

There was one minor deviation to the SAFER Plan. Chlordane was detected in a PCB analysis. Therefore, pesticides were added to this sample. There were no other deviations from the SAFER Plan.

\section{D.9.2 Investigation Results}

The following sections provide analytical results from the samples collected to complete investigation activities as outlined in the SAFER Plan. Investigation samples were analyzed for the SAFER Plan-specified COPCs, which included VOCs, SVOCs, TPH-DRO, TPH-GRO, RCRA metals, PCBs, and gamma-emitting radionuclides. The analytical parameters and laboratory methods used to analyze the investigation samples are listed in Table D.2-2. Table D.9-1 lists the sample-specific analytical suite for CAS 23-02-07.

Analytical results from the environmental samples with concentrations exceeding MDCs are summarized in the following sections. An evaluation was conducted on all contaminants detected above MDCs by comparing individual concentration or activity results against the FALs. Establishment of the FALs is presented in Section H.1.0. The FALs were established as the corresponding PAL concentrations or activities if the contaminant concentrations were below their respective PALs.

\section{D.9.2.1 Volatile Organic Compounds}

Analytical results for VOCs in environmental samples collected at this CAS that were detected above MDCs are presented in Table D.9-2. No VOCs were detected at concentrations exceeding their respective PALs. The FALs were established at the PAL concentrations. 
Table D.9-2

Sample Results for Total VOCs Detected above MDCs at CAS 23-02-07, Underground Storage Tank

\begin{tabular}{|c|c|c|c|c|}
\hline \multirow{2}{*}{$\begin{array}{c}\text { Sample } \\
\text { Location }\end{array}$} & \multirow{2}{*}{$\begin{array}{c}\text { Sample } \\
\text { Number }\end{array}$} & \multirow{2}{*}{$\begin{array}{c}\text { Depth } \\
\text { (ft bgs) }\end{array}$} & Acetone & COPC (mg/kg) \\
\cline { 3 - 5 } & & & $\mathbf{5 4 , 0 0 0}$ & $\mathbf{2 1}$ \\
\hline \multicolumn{2}{|c|}{ FALs } & & $0.013(\mathrm{~J})$ & $0.0018(\mathrm{~J})$ \\
\hline \hline \multirow{2}{*}{ G01 } & $130 \mathrm{G} 001$ & $1.5-2.0$ & -- & $0.0029(\mathrm{~J})$ \\
\hline \multirow{2}{*}{ G02 } & $130 \mathrm{G} 002$ & $7.5-8.0$ & -- & $0.0029(\mathrm{~J})$ \\
\cline { 2 - 5 } & $130 G 003$ & $7.5-8.0$ & -- & $0.0031(\mathrm{~J})$ \\
\hline
\end{tabular}

$--=$ Not detected above MDCs.

$\mathrm{J}=$ Estimated value

\section{D.9.2.2 Semivolatile Organic Compounds}

Analytical results for SVOCs in environmental samples collected at this CAS that were detected above MDCs are presented in Table D.9-3. No SVOCs were detected at concentrations exceeding the respective PALs. The FALs were established at the PAL concentrations.

Table D.9-3

Sample Results for Total SVOCs Detected above MDCs at CAS 23-02-07, Underground Storage Tank

\begin{tabular}{|c|c|c|c||}
\hline \multirow{2}{*}{$\begin{array}{c}\text { Sample } \\
\text { Location }\end{array}$} & \multirow{2}{*}{$\begin{array}{c}\text { Sample } \\
\text { Number }\end{array}$} & $\begin{array}{c}\text { Depth } \\
\text { (ft bgs) }\end{array}$ & COPC (mg/kg) \\
\cline { 4 - 4 } & & & Bis(2-ethylhexyl)Phthalate \\
\hline \multicolumn{3}{|c|}{ FAL } & $\mathbf{1 2 0}$ \\
\hline \hline G01 & $130 \mathrm{G} 001$ & $1.5-2.0$ & $0.67(\mathrm{~J})$ \\
\hline
\end{tabular}

$\mathrm{J}=$ Estimated value

\section{D.9.2.3 Total Petroleum Hydrocarbons}

Analytical results for TPH-DRO and -GRO in soil samples collected at this CAS that were detected above MDCs are presented in Table D.9-4. Analytical results for one soil sample (130G001) exceeded the PAL of $100 \mathrm{mg} / \mathrm{kg}$ for TPH-DRO and was moved on to a Tier II evaluation to determine FALs for the hazardous constituents of TPH-DRO. Concentrations of the 20 hazardous constituents 
Table D.9-4

\section{Sample Results for TPH-DRO and -GRO Detected above MDCs at CAS 23-02-07, Underground Storage Tank}

\begin{tabular}{|c|c|c|c|c|}
\hline \multirow{2}{*}{$\begin{array}{c}\text { Sample } \\
\text { Location }\end{array}$} & \multirow{2}{*}{$\begin{array}{c}\text { Sample } \\
\text { Number }\end{array}$} & \multirow{2}{*}{$\begin{array}{c}\text { Depth } \\
\text { (ft bgs) }\end{array}$} & DRO & COPC (mg/kg) \\
\cline { 4 - 5 } & & & $\mathbf{1 0 0}$ & $\mathbf{1 0 0}$ \\
\hline \multicolumn{3}{|c|}{ FALs } & $\mathbf{3 5 0}$ & 0.54 \\
\hline \hline G01 & $130 \mathrm{G} 001$ & $1.5-2.0$ & 32 & -- \\
\hline G03 & $130 \mathrm{G} 004$ & $8.0-8.5$ & & \\
\hline
\end{tabular}

-- = Not detected above MDCs.

of TPH-DRO did not exceed MDCs; therefore, TPH-DRO is not considered a COC. The calculation of FALs for the hazardous constituents of TPH-DRO is presented in Section H.1.10, evaluation of TPH-DRO SSTLS.

\section{D.9.2.4 RCRA Metals}

Analytical results for RCRA metals in environmental samples collected at this CAS that were detected above MDCs are presented in Table D.9-5. No metals were detected at concentrations exceeding their PALs. The FALs were established at the PAL concentrations.

Table D.9-5

Sample Results for RCRA Metals Detected above MDCs at CAS 23-02-07, Underground Storage Tank

\begin{tabular}{|c|c|c|c|c|c|c|c|c|}
\hline \multirow[b]{2}{*}{$\begin{array}{c}\text { Sample } \\
\text { Location }\end{array}$} & \multirow[b]{2}{*}{$\begin{array}{l}\text { Sample } \\
\text { Number }\end{array}$} & \multirow[b]{2}{*}{$\begin{array}{l}\text { Depth } \\
\text { (ft bgs) }\end{array}$} & \multicolumn{6}{|c|}{ COPC $(\mathrm{mg} / \mathrm{kg})$} \\
\hline & & & 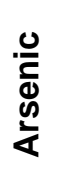 & 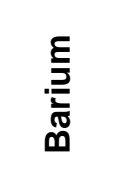 & 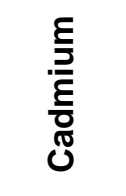 & 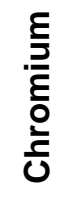 & ఫ్త & $\begin{array}{l}\frac{\lambda}{J} \\
\frac{0}{0} \\
\sum\end{array}$ \\
\hline \multicolumn{3}{|c|}{ FALs } & 23 & 67,000 & 450 & 450 & 800 & 310 \\
\hline G01 & 130G001 & $1.5-2.0$ & 5.2 & 190 & $0.32(\mathrm{~J}-)$ & 7.6 & 430 & 0.024 \\
\hline \multirow{2}{*}{ G02 } & 130G002 & $7.5-8.0$ & 3 & 28 & 0.063 & 1.9 & 2 & -- \\
\hline & 130G003 & $7.5-8.0$ & 2.8 & 23 & -- & 1.8 & 1.8 & -- \\
\hline G03 & 130G004 & $8.0-8.5$ & 3.3 & 330 & 0.15 & 3 & 11 & 0.017 \\
\hline
\end{tabular}

$--=$ Not detected above MDCs.

$\mathrm{J}-=$ The result is an estimated quantity, but the result may be biased low. 


\section{D.9.2.5 Polychlorinated Biphenyls}

No PCBs were detected above MDCs at CAS 23-02-07. The FALs were established at the PAL concentrations.

\section{D.9.2.6 Pesticides}

Pesticide concentrations in the environmental samples collected at this CAS are presented in Table D.9-6. No pesticides were detected at concentrations exceeding their PALs. The FALs were established at the PAL concentrations.

Table D.9-6

Sample Results for Pesticides Detected above MDCs at CAS 23-02-07, Underground Storage Tank

\begin{tabular}{|c|c|c|c|c|}
\hline \multirow{2}{*}{$\begin{array}{c}\text { Sample } \\
\text { Location }\end{array}$} & \multirow{2}{*}{$\begin{array}{c}\text { Sample } \\
\text { Number }\end{array}$} & \multirow{2}{*}{$\begin{array}{c}\text { Depth } \\
\text { (ft bgs) }\end{array}$} & \multicolumn{2}{|c|}{ COPC (mg/kg) } \\
\cline { 4 - 5 } & & & $4,4 '-D D T$ & Chlordane \\
\hline \multicolumn{2}{|c|}{ FALs } & 7 & 6.5 \\
\hline \hline G01 & $130 G 001$ & $1.5-2.0$ & $0.0057(\mathrm{~J})$ & $0.47(\mathrm{~J})$ \\
\hline
\end{tabular}

$\mathrm{J}=$ Estimated value

\section{D.9.2.7 Gamma-Emitting Radionuclides}

Analytical results for gamma-emitting radionuclides in environmental samples collected at this CAS that were detected above MDCs are presented in Table D.9-7. No gamma-emitting radionuclides were detected at concentrations exceeding their PALs. Because the gamma-emitting radionuclides were less than the PAL, no further isotopic analysis was necessary. The FALs were established at the PAL concentrations.

\section{D.9.3 Nature and Extent of Contamination}

Based on the results of the CAI including the analytical results for environmental samples collected, there are no COCs at CAS 23-02-07. 
Table D.9-7

Sample Results for Gamma-Emitting Radionuclides Detected above MDCs at CAS 23-02-07, Underground Storage Tank

\begin{tabular}{|c|c|c|c|c|c|c|}
\hline \multirow{2}{*}{$\begin{array}{c}\text { Sample } \\
\text { Location }\end{array}$} & \multirow{2}{*}{$\begin{array}{l}\text { Sample } \\
\text { Number }\end{array}$} & \multirow{2}{*}{$\begin{array}{l}\text { Depth } \\
\text { (ft bgs) }\end{array}$} & \multicolumn{4}{|c|}{ COPC (pCi/g) } \\
\hline & & & Ac-228 & $\mathrm{Pb}-212$ & $\mathrm{~Pb}-214$ & TI-208 \\
\hline \multicolumn{3}{|c|}{ FALs } & 5 & 5 & 5 & 5 \\
\hline G01 & 130G001 & $1.5-2.0$ & -- & $0.75(\mathrm{~J})$ & $0.67(\mathrm{~J})$ & -- \\
\hline \multirow{2}{*}{ G02 } & $130 \mathrm{G} 002$ & $7.5-8.0$ & -- & -- & $0.43(\mathrm{~J})$ & -- \\
\hline & 130G003 & $7.5-8.0$ & -- & $0.223(\mathrm{~J})$ & $0.41(\mathrm{~J})$ & -- \\
\hline G03 & $130 \mathrm{G} 004$ & $8.0-8.5$ & 1.3 & $1.24(\mathrm{~J})$ & $0.99(\mathrm{~J})$ & 0.4 \\
\hline
\end{tabular}

$--=$ Not detected above MDCs.

$\mathrm{J}=$ Estimated value

\section{D.9.4 Revised Conceptual Site Model}

The SAFER Plan requirements were met at this CAS, and no revisions were necessary to the CSM. 


\section{D.10.0 Waste Management}

Section D.10.1 addresses PSM and IDW management for CAU 130. No remediation wastes were generated.

\section{D.10.1 Investigation-Derived Waste}

Investigation-derived waste was generated during the field investigation activities of CAU 130 . Investigation-derived waste was segregated to the greatest extent possible, and waste minimization and recycling techniques were integrated into the field activities to reduce the amount of waste generated. Controls were in place to minimize the use of hazardous materials and the unnecessary generation of hazardous and/or mixed waste. Decontamination activities were planned and executed to minimize the volume of rinsate generated.

One hazardous waste accumulation area and two satellite accumulation areas were activated to manage hazardous and potentially hazardous waste generated during the CAI. The lead bricks removed from CAS 07-02-01 were beneficially recycled and, therefore, not considered to be waste. The amount, type, and source of waste placed into each drum was recorded in waste container logbooks that are maintained in the project files. Potentially hazardous waste generated during the CAI was placed in containers and labeled as "Hazardous Waste - Pending Analysis.” Three drums of potentially hazardous waste were generated during the CAI.

\section{D.10.1.1 Waste Streams}

The waste generated by site closure activities at CAU 130 was segregated into the following waste streams:

- Industrial waste (i.e., PPE, disposable sampling equipment, plastic sheeting, glass/plastic sample jars, aluminum foil, and other debris such as concrete, asphalt, and piping)

- Liquids (from an abandoned water line in CAS 23-02-07)

- $\quad$ Batteries (dry cell)

- Tar residue 


\section{D.10.1.2 Waste Generated}

Wastes generated during this CAI were approximately $16 \mathrm{yd}^{3}$ of demolition debris, 1 standard size bag of PPE, 126 batteries, one-half 55-gal drum of tar residue, 10 lead bricks, two 55-gal drums and one 10-gal drum of liquid, and general office wastes. These wastes were managed as follows:

- All PPE and disposable sampling equipment generated during site investigation activities was determined to be sanitary based on observations and process knowledge. The waste was bagged, labeled, and placed in designated sanitary industrial waste bins located at Building 23-153 and allocated for disposal at the NTS Industrial Waste Landfill.

- Demolition debris (piping, concrete, asphalt, steel, batteries) generated during site investigation activities was determined to be sanitary based on process knowledge and visual inspection. The waste was disposed of at the NTS Industrial Waste Landfill.

- The tar residue was characterized based on direct sample data as hydrocarbon waste exceeding the regulatory threshold, established by the State of Nevada regulations (NDEP, 1997a and b). The tar residue was disposed in the permitted NTS Hydrocarbon Landfill.

- The liquid from CAS 23-02-07 was characterized based on direct sample data and disposed at the NTS Area 23 Lagoon.

Sanitary industrial waste was inspected and disposed of in designated sanitary industrial waste bins located at Building 23-153 and allocated for disposal at the NTS Industrial Waste Landfill. 


\section{D.11.0 Quality Assurance}

This section contains a summary of QA/QC measures implemented during the sampling and analysis activities conducted in support of the CAU 130 CAI. The following sections discuss the data validation process, QC samples, and nonconformances. A detailed evaluation of the DQIs is presented in Section 4.1.

Laboratory analyses were conducted for samples used in the decision-making process to provide a quantitative measurement of any COPCs present. Rigorous QA/QC was implemented for all laboratory samples including documentation, verification and validation of analytical results, and affirmation of DQI requirements related to laboratory analysis. Detailed information regarding the QA program is contained in the Industrial Sites QAPP (NNSA/NV, 2002).

\section{D.11.1 Data Validation}

Data validation was performed in accordance with the Industrial Sites QAPP and approved protocols and procedures. All laboratory data from samples collected and analyzed for CAU 130 were evaluated for data quality in a tiered process described in Sections D.11.1.1 through D.11.1.3. Data were reviewed to ensure that samples were appropriately processed and analyzed, and the results were evaluated using validation criteria. Documentation of the data qualifications resulting from these reviews is retained in project files as a hard copy and electronic media.

One hundred percent of the data analyzed as part of this investigation were subjected to Tier I and Tier II evaluations. A Tier III evaluation was performed on approximately 5 percent of the data analyzed.

\section{D.11.1.1 Tier I Evaluation}

Tier I evaluation for chemical and radiochemical analysis examines, but is not limited to:

- Sample count/type consistent with chain of custody.

- Analysis count/type consistent with chain of custody.

- Correct sample matrix.

- Significant problems stated in cover letter or case narrative.

- Completeness of certificates of analysis. 
- Completeness of Contract Laboratory Program (CLP) or CLP-like packages.

- Completeness of signatures, dates, and times on chain of custody.

- Condition-upon-receipt variance form included.

- Requested analyses performed on all samples.

- Date received/analyzed given for each sample.

- Correct concentration units indicated.

- Electronic data transfer supplied.

- Results reported for field and laboratory QC samples.

- Whether or not the deliverable met the overall objectives of the project.

\section{D.11.1.2 Tier II Evaluation}

Tier II evaluation for chemical analysis examines, but is not limited to:

- Correct detection limits achieved.

- Sample date, preparation date, and analysis date for each sample.

- Holding time criteria met.

- Quality control batch association for each sample.

- Cooler temperature upon receipt.

- Sample pH for aqueous samples, as required.

- Detection limits properly adjusted for dilution, as required.

- Blank contamination evaluated and applied to sample results/qualifiers.

- Matrix spike/matrix spike duplicate (MSD) percent recoveries (\%R) and RPDs evaluated and qualifiers applied to laboratory results, as necessary.

- Field duplicate RPDs evaluated using professional judgment and qualifiers applied to laboratory results, as necessary.

- Laboratory duplicate RPDs evaluated and qualifiers applied to laboratory results, as necessary.

- Surrogate \%R evaluated and qualifiers applied to laboratory results, as necessary.

- Laboratory control sample (LCS) \%R evaluated and qualifiers applied to laboratory results, as necessary.

- Initial and continuing calibration evaluated and qualifiers applied to laboratory results, as necessary.

- Internal standard evaluation.

- Mass spectrometer tuning criteria.

- Organic compound quantitation. 
- Inductively coupled plasma interference check sample evaluation.

- Graphite furnace atomic absorption QC.

- Inductively coupled plasma serial dilution effects.

- Recalculation of 10 percent of laboratory results from raw data.

Tier II evaluation for radiochemical analysis examines, but is not limited to:

- Correct detection limits achieved.

- Blank contamination evaluated and, if significant, qualifiers are applied to sample results.

- Certificate of Analysis consistent with data package documentation.

- Quality control sample results (duplicates, LCSs, laboratory blanks) evaluated and used to determine laboratory result qualifiers.

- Sample results, uncertainty, and MDC evaluated.

- Detector system calibrated with National Institute of Standards and Technology (NIST)-traceable sources.

- Calibration sources preparation was documented, demonstrating proper preparation and appropriateness for sample matrix, emission energies, and concentrations.

- Detector system response to daily or weekly background and calibration checks for peak energy, peak centroid, peak full-width half-maximum, and peak efficiency, depending on the detection system.

- Tracers NIST-traceable, appropriate for the analysis performed, and recoveries that met QC requirements.

- Documentation of all QC sample preparation complete and properly performed.

- Spectra lines, photon emissions, particle energies, peak areas, and background peak areas support the identified radionuclide and its concentration.

\section{D.11.1.3 Tier III Evaluation}

The Tier III review is an independent examination of the Tier II evaluation. A Tier III review of 5 percent of the sample analytical data was performed by TLI Solutions, Inc. in Golden, Colorado. Tier II and Tier III results were compared and where differences are noted, data were reviewed and changes were made accordingly. This review included the following additional evaluations:

- Review:

- Case narrative, chain of custody, and sample receipt forms 
- Lab qualifiers (applied appropriately)

- Method of analyses performed as dictated by the chain of custody

- Raw data, including chromatograms, instrument printouts, preparation logs, and analytical logs

- Manual integrations to determine whether the response is appropriate

- Data package for completeness

- Determine sample results qualifiers through the evaluation of (but not limited to):

- Tracers and QC sample results (e.g., duplicates, LCSs, blanks, MSs) evaluated and used to determine sample results qualifiers

- Sample preservation, sample preparation/extraction and run logs, sample storage, and holding time

- Instrument and detector tuning

- Initial and continuing calibrations

- Calibration verification (initial, continuing, second source)

- Retention times

- Second column and/or second detector confirmation

- Mass spectra interpretation

- Interference check samples and serial dilutions

- Post digestion spikes and method of standard additions

- Breakdown evaluations

- Perform calculation checks of:

- At least one analyte per QC sample and its recovery

- At least one analyte per initial calibration curve, continuing calibration verification, and second source recovery 
- At least one analyte per sample that contains positive results (hits); radiochemical results only require calculation checks on activity concentrations (not error)

- Verify that target compound detects identified in the raw data are reported on the results form.

- Document any anomalies for the laboratory to clarify or rectify. The contractor should be notified of any anomalies.

\section{D.11.2 Field QC Samples}

Field QC samples consisted of 18 trip blanks, 1 equipment rinsate blanks, 7 field blanks, 1 source blanks, 7 MS/MSDs, and 7 FDs collected and submitted for analysis by the laboratory analytical methods shown in Table D.2-2. The QC samples were assigned individual sample numbers and sent to the laboratory "blind." Additional samples were selected by the laboratory to be analyzed as laboratory duplicates.

Field blanks, source blanks, and equipment rinsates were analyzed for the applicable parameters listed in Table D.2-2 and trip blanks were analyzed for VOCs only.

During the CAI, seven FDs were sent as blind samples to the laboratory to be analyzed for the investigation parameters listed in Table D.2-2. For these samples, the duplicate results precision (i.e., RPDs between the environmental sample results and their corresponding FD sample results) were evaluated.

\section{D.11.2.1 Laboratory QC Samples}

Analysis of preparation blanks (PBs) were performed on each sample delivery group (SDG) for inorganics. Analysis for surrogate spikes and method blanks were performed on each SDG for organics only. Initial and continuing calibration and LCSs were performed for each SDG. The results of these analyses were used to qualify associated environmental sample results. The laboratory included a PB, LCS, and a laboratory duplicate sample with each batch of field samples analyzed for radionuclides. Documentation of data qualifications resulting from the application of these guidelines is retained in project files as both hard copy and electronic media. 


\section{D.11.3 Field Nonconformances}

There were no field nonconformances identified for the CAI. There is one field discrepancy identified for the CAU 130 CAI. Sample 130F003 analysis of PCBs was marked on the COC where it should have been marked for gamma spectroscopy. The laboratory was notified of the discrepancy, and this was corrected.

\section{D.11.4 Laboratory Nonconformances}

Laboratory nonconformances are generally due to inconsistencies in the analytical instrumentation operation, sample preparations, extractions, missed holding times, and fluctuations in internal standard and calibration results. During data validation, analytical laboratory quality impacting items are accounted for, reviewed, examined, and resolved. During this process, data qualifiers are applied to the data when appropriate. 


\section{D.12.0 Summary}

The CAU 130 activities resulted in the following expectations and findings from the CAI:

- Corrective Action Site 01-02-01 was expected to be a UST associated with the Apple II District. The CAI discovered no UST, but an abandoned natural gas distribution system was discovered.

- Corrective Action Site 07-02-01 was expected to be USTs. The CAI discovered no USTs. The excavation revealed five concrete pads and confirmed Station 7-235 as empty. There was PSM in the form of lead bricks that were removed as part of clean closure for the site.

- Corrective Action Site 10-02-01 was expected to be a UST. The CAI discovered the site was an underground storage vault. The vault had 118 dry cell batteries that were removed and disposed.

- Corrective Action Site 20-02-03 was expected to be a UST associated with gas sampling. The CAI discovered no UST at either the planned engineering drawing location or the geophysical located anomaly. The geophysical anomaly was two t-posts.

- Corrective Action Site 20-99-05 was an approximate 30-by-40-ft area of a tar residue. The tar residue was direct sampled for disposal along with environmental confirmation soil samples below the tar at two biased locations. The tar residue was picked up and disposed as appropriate.

- Corrective Action Site 22-02-02 was expected to be buried UST piping that connected a former gas fill station to the former Building T-951. The CAI discovered the buried UST piping, and it was removed and disposed as appropriate.

- Corrective Action Site 23-02-07 was expected to be a former waste oil UST that had been grouted and closed. The CAI discovered the UST, and it has been grouted and closed in place as documented.

Organic, inorganics, and radionuclide contaminants detected in environmental samples during the CAI were evaluated against FALs to determine the nature and extent of COCs for CAU 130.

Assessment of the data generated from investigation activities indicates the FALs were not exceeded.

Based on the analytical results of the environmental samples collected at the CAU 130 CASs, no contamination has been released to the soil at any CAU 130 CAS. The PSM from CAS 07-02-01 was removed as part of the corrective action of clean closure. Therefore, no further corrective actions are required at this CAU. 


\section{D.13.0 References}

BN, see Bechtel Nevada.

Bechtel Nevada. 1995. Nevada Test Site Performance Objective for Certification of Nonradioactive Hazardous Waste, Rev. 0, G-E11/96.01. Las Vegas, NV.

Bechtel Nevada. 1999. An Aerial Radiological Survey of the Nevada Test Site, DOE/NV/11718--324. Prepared for the U.S Department of Energy, Nevada Operations Office. Nellis Air Force Base, NV: Remote Sensing Laboratory.

Clesceri, L.S., A.E. Greenberg, and A.D. Eaton, eds. 1998. Standard Methods for the Examination of Water and Wastewater, $20^{\text {th }}$ edition. Published by American Public Health Association, American Water Works Association, and Water Environmental Federation.

DOE, see U.S. Department of Energy.

DOE/NV, see U.S. Department of Energy, Nevada Operations Office.

EPA, see U.S. Environmental Protection Agency.

IT, see IT Corporation

IT Corporation. 1997. “Radiological Survey, ER Spills/Background Sampling,” 28 August. Las Vegas, NV.

IT Corporation. 2002. “Radiological Survey form Completed by C. Speer,” 16 August. Las Vegas, NV.

NDEP, see Nevada Division of Environmental Protection.

NNSA/NV, see U.S. Department of Energy, National Nuclear Security Administration Nevada Operations Office.

NNSA/NSO, see U.S. Department of Energy, National Nuclear Security Administration Nevada Site Office.

Nevada Division of Environmental Protection. 1997a (as amended). Class III Solid Waste Disposal Site for Hydrocarbon Burdened Soils, Area 6 of the NTS, Permit SW 13097 02. Reno, NV.

Nevada Division of Environmental Protection. 1997b (as amended). Class III Solid Waste Disposal Site; U10C, Area 9 of the NTS, Permit SW 13097 03. Carson City, NV. 
Nicosia, W., Stoller-Navarro Joint Venture. 2003. Memorandum to M. England (SAIC) entitled, "Radiological Land Area Surveys of Various Locations at the Nevada Test Site for Preliminary Assessments,” 3 March.

RSL, see Remote Sensing Laboratory.

Remote Sensing Laboratory. 1989. Aerial photograph “6611-150.” September. Las Vegas, NV.

Remote Sensing Laboratory. 1999. Aerial photograph “9997-4.” March. Las Vegas, NV.

SNJV, see Stoller-Navarro Joint Venture.

SNJV GIS, see Stoller-Navarro Joint Venture Geographic Information Systems.

Stoller-Navarro Joint Venture. 2006. Model Statement of Work for Analytical Laboratories, Rev. 0. February. Las Vegas, NV.

Stoller-Navarro Joint Venture Geographic Information Systems. 2009. ESRI ArcGIS Software.

U.S. Department of Energy. 1997. The Procedures Manual of the Environmental Measurements Laboratory, HASL-300. 28th Ed., Vol. I. February. New York, NY.

U.S. Department of Energy, National Nuclear Security Administration Nevada Operations Office. 2002. Industrial Sites Quality Assurance Project Plan, Nevada Test Site, Nevada, Rev. 3, DOE/NV--372. Las Vegas, NV.

U.S. Department of Energy, National Nuclear Security Administration Nevada Site Office. 2004. NV/YMP Radiological Control Manual, Rev. 5, DOE/NV/11718-079. Prepared by Bechtel Nevada. Las Vegas, NV.

U.S. Department of Energy, National Nuclear Security Administration Nevada Site Office. 2006. Industrial Sites Project Establishment of Final Action Levels, Rev. 0, DOE/NV--1107. Las Vegas, NV.

U.S. Department of Energy, National Nuclear Security Administration Nevada Site Office. 2008. Streamlined Approach for Environmental Restoration (SAFER) CAU 130: Storage Tanks, Nevada Test Site, Nevada, Rev. 0, DOE/NV--1276. Las Vegas, NV.

U.S. Department of Energy, Nevada Operations Office. 2000. Nevada Test Site, NV Digital Orthophoto Quadrangles showing approximate location of CAS 07-02-01, 26 August. Las Vegas, NV.

U.S. Environmental Protection Agency. 1980. Prescribed Procedures for Measurement of Radioactivity in Drinking Water, EPA 600/4-80-032. Cincinnati, OH: Environmental Monitoring and Support Laboratory Office of Research and Development. 
U.S. Environmental Protection Agency. 2008. SW-846 On-Line, Test Methods for Evaluating Solid Waste, Physical/Chemical Methods. As accessed at http://www.epa.gov/epaoswer/hazwaste/test/main.htm on 3 November. 


\section{Appendix E \\ Waste Disposition Documentation \\ (7 Pages)}




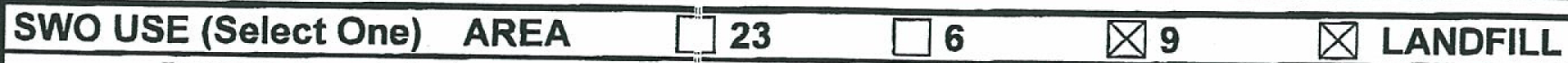

For waste characterization, approval, and/or assistance, contact Solid Waste Operation (SWO) at 5-7898.

REQUIRED: WIISTE GERERATOR INFORMATION

(This form is for rolloffs, dump trucks, and other onsite disposal of materials.)

Waste Generator: Mark Heser (SNJV, WO)

Phone Number: (o)5-2124; (c)496-0150

Location / Origin: CAU 130, CAS 10-02-01, Container IDs 130C01 thru $130 \mathrm{C0} 03$ and bulk debris waste. (1300 5 )

\begin{tabular}{|c|c|c|c|c|}
\hline \multicolumn{2}{|c|}{ Waste Category: (check one) } & \multirow{2}{*}{$\begin{array}{l}\square \text { Con'mercial } \\
\square \text { Putrescrible }\end{array}$} & \multicolumn{2}{|l|}{$\otimes$ Industrial } \\
\hline Waste Type: & $\square$ NTS & & $\triangle$ FFACO-onsite & $\square \mathrm{WAC}$ \\
\hline (check one) & $\square$ Non-Putrescible & $\square$ Asbestos Containing Material & $\square$ FFACO-offsite & $\square$ Historic DOE/NV \\
\hline \multicolumn{2}{|c|}{ Pollution Prevention Category: (check one) } & Q Environmental management & $\square$ Defense Projects & $\square \mathrm{YMP}$ \\
\hline \multirow{2}{*}{\multicolumn{2}{|c|}{ Pollution Prevention Category: (check one) }} & $\triangle$ Cleain-Up & $\square$ Routine & \\
\hline & Method of Characterization: (check one) & $\square$ Sanupling \& Analysis & 凶 Process Knowled & Q Contents \\
\hline
\end{tabular}

Prohibited Waste at all three Radioactive waste; RCRA waste; Hazardous waste; Free liquids, PCBs above TSCA regulatory NTS landfills:

Additional Prohibited Waste at the Area 9 U10C Landfill: levels, and Medical wastes (needles, sharps, bloody clothing).

Sewage Sludge, Anirnal carcasses, Wet garbage (food waste); and Friable asbestos

\section{REQUIRED: WASTE CONTENTS ALLOWABLE WASTES}

Check all allowable wastes that are contained within this load:

NOTE: Waste disposal at the Area 6 Hydrocarbon Landfill must have come into contact with petroleum hydrocarbons or coolants, such as: gasoline (no benzene, lead); jet fuel; diesel fuel; lubricants and hydraulics; kerosene; asphaltic petroleum hydrocarbon; and ethylene glycol.
Acceptable waste at any NTS landfill:
$\square$ Asphalt
\Metal
$\square$ Wood
$\square$ Paper
$\square$ Soil
$\square$ Rocks / unaltered geologic materials
$\square$ Rubber (excluding tires)
$\square$ Empty containers
$\square$ Demolition debris
$凶$ Cement \& concrete

$\square$ Plastic $\square$ Wire $\square$ Cable $\square$ Cloth $\square$ Insulation (non-Asbestosform)
$\square$ Manufactured items: (swamp coolers, furniture, rugs, carpet, electronic components, PPE, etc.)

$\square$ Plastic $\square$ Wire $\square$ Cable $\square$ Cloth $\square$ Insulation (non-Asbestosform)
$\square$ Manufactured items: (swamp coolers, furniture, rugs, carpet, electronic components, PPE, etc.)

$\square$ Plastic $\square$ Wire $\square$ Cable $\square$ Cloth $\square$ Insulation (non-Asbestosform)
$\otimes$ Manufactured items: (swamp coolers, furniture, rugs, carpet, electronic components, PPE, etc.)
Additional waste accepted at the Area 23 Mercury Landfill: $\square$ Office Waste $\square$ Food Wast
$\square$ Asbestos
$\square$ Friable

$\square$ Non-Friable (contact SWO if regulated load)

Quantity:

Additional waste accepted at the Area 9 U10c Landifill:

$\square$ Non-friable asbestos
$\square$ Light ballasts (contact SwO) $\square$ Drained automotiles and military vehicles
$\square$ Hydrocarbons (contact SwO) $\square$ Other 3 dr Dry cell zinc/carbon batteries

Solid fractions from sand/oil/water

$\square$ Deconned Underground and Above Ground Tanks

\section{Additional waste accepted at the Area 6 Hydrocarbon Landfill:}
$\square$ Septic sludge
$\square$. Rags
$\square$ Drained fulal filters (gas \& diesel)
Plants
$\square$ Soil
$\square$ Sludge frorn sand/oil/water separators
$\square$ Crushed non-teme plated oil filters REQUIRED: WIASTE GENERATOR SIGNATURE

Initials: (if initialed, no radiological clearance is necessary.)

The above mentioned waste was generated outside cf a Controlled Waste Managem knowledge, does not contain radiological materials.

To the best of my knowledge, the waste described at.ove contains only those materi site. I have verified this through the waste characterilzation method identified above prohibited and allowable waste items. I have contaclied Property Management and $h$ is approved for disposal in the landfill.

Print Name: John M. Fuler

Signature: John M. Fowler

$$
11-6-08
$$

Date: $10 / 17 / 68$
Radiological Survey Release for Waste Disposal RGJnitials

X This contalner/load meets the criteria for no added man-made radioactive material ! This container/load meets the criteria for Radcon Manual Table 42 releasí limits. This Eontainer/loadehis exempt from surviay due tolprocess kphwiledice and origin. SIGNATURE: Chao-Hsiung Tung DATE: $\underbrace{\text { due tolprof }}_{\text {BN-0646(10/05) }}$ BN-0646 (10/05) Note: "Food waste, office trash and animal carcasses. do not require a radiological clearance. Freon-containing appliances
must have signed removal certification statement with Load Verification."

SWO USE ONLY
Load Weight (net from scale or estimate): 7,860

i) $-6-08$
Signature of Certifier:

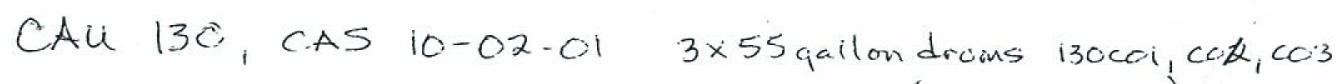

UNCONTROLLED Wheiff Printed (concrete \& metal) izecos 
RECEIVED, subject to the classifications and tariffs in effect on the date of the issue of this Bill of Lading the property described below, in apparent good order, except as noted (contents and condition of contents of packages unknown) marked, consigned, and destined shown below, which said carrier (the word carrier being understood throughout this contract as meaning any person or corporation in

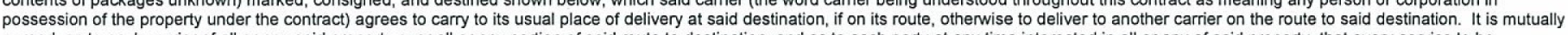
agreed, as to each carrier of all or any said property over all or any portion of said route to destination, and as to each party at any time interested in all or any of said property, that every service to be performed hereunder shall be subject to all the terms and conditions of the Uniform Domestic Straight Bill of Lading set forth (1) in Uniform Freight Classification in effect on the date hereof, if this is a rail or rail-water shipment, or (2) in the applicable motor carrier classification or tariff if this is a motor carrier shipment.

Shipper hereby certifies that he is familiar with all the terms and conditions of the said bill of lading, including those on the back thereof, set forth in the classification or tariff which governs the transportation of this shipment and the said terms and conditions are hereby agreed to by the shipper and accepted for himself and his assigns.

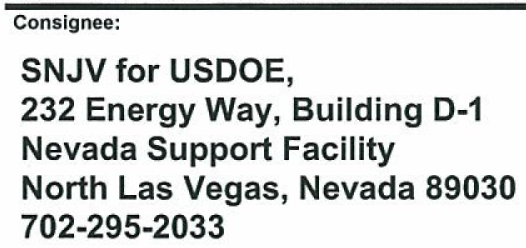

SNJV for USDOE, 232 Energy Way, Building D-1

Nevada Support Facility North Las Vegas, Nevada 89030 702-295-2033

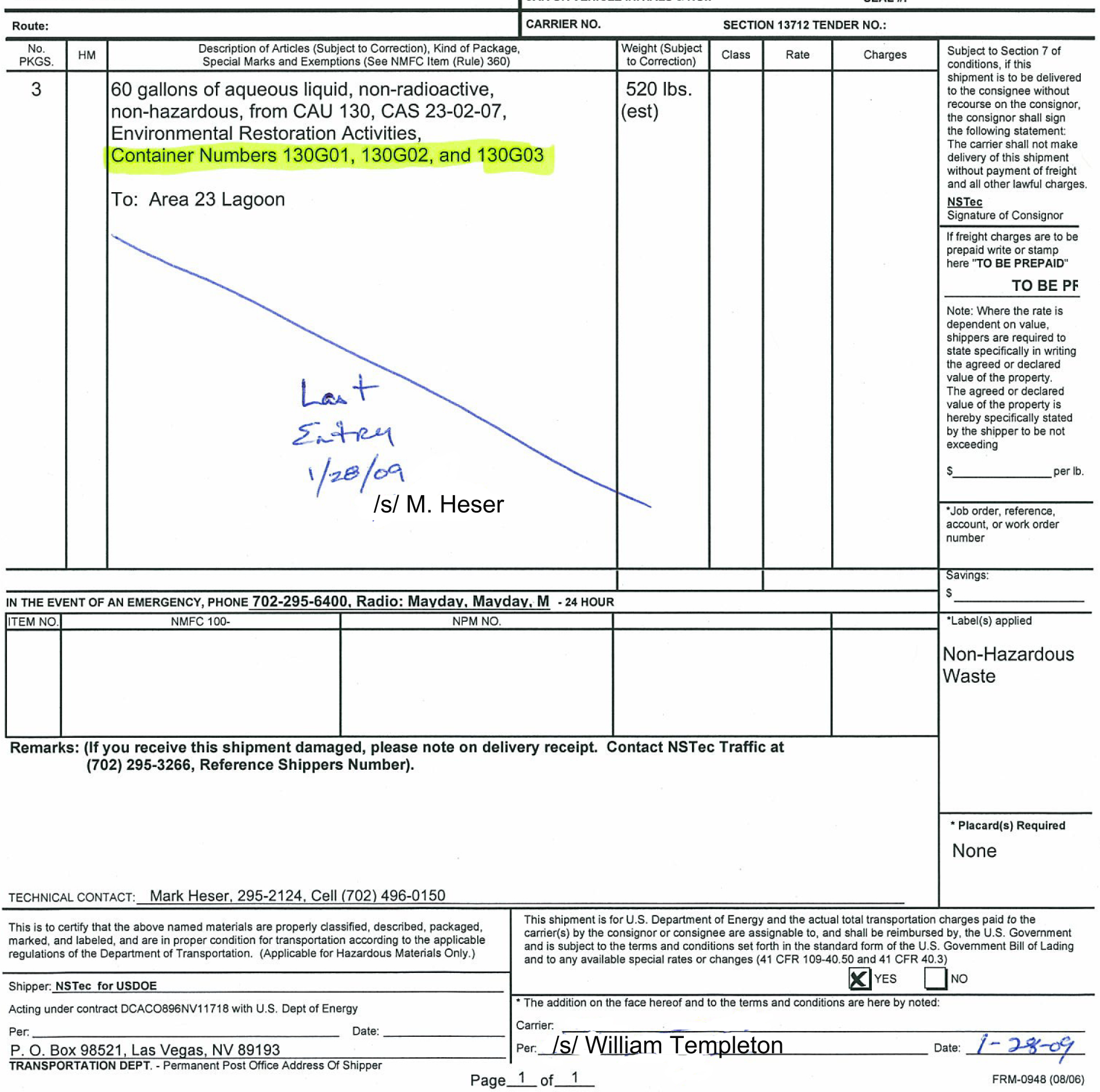




\begin{tabular}{|llllll}
\hline SWO USE (Select One) AREA & $\square 23$ & $\square 6$ & $\square 9$ & Q \\
\hline For wastechaflLL
\end{tabular}

For waste characterization, approval, and/or assistance, contact Solid Waste Operation (SWO) at 5-7898.

$$
\text { REQUIRED: WASTE GERERATOR INFORMATION }
$$

(This form is for rolloffs, dump trucks, and other onsite disposal of materials.)

Waste Generator: Mark Heser (SNJV, WO)

Phone Number: (o)5-2124: (c)496-015

Location / Origin: CAU 130, CAS 23-02-07. Empty drums - Container IDs 130G01; 130G02 and 130G03

Waste Category: (check one)

Waste Type: $\square$ NTS

(check one) $\square$ Non-Putrescible $\square$ Asbestos Containing Material $\square$

(chack one) $\square$ Non-Putrescible $\square$ Asbestos Containing Material $\square$

$\square$ Commercial

区 Industrial

$\triangle$ FFACO-onsite

$\square$ Asbestos Containing Material

Pollution Prevention Category: (check one)

Pollution Prevention Category: (eheck one)

$\square$ FFACO-offsite

$\triangle$ Cleânulup

Defense Projects

$\square$ Routine

NTS landfills:

Additional Prohibited Waste

at the Area 9 U10C Landfill:

Radioactive waste; RCRA waste; Hazardous waste; Free liquids,
levels, and Medical wastes (needles, sharps, bloody clothing).

Sewage Sludge, Animal carcasses, Wet garbage (food waste); and Friable asbestos

REQUIRED: WASTE CONTENTS ALLOWABLE WASTES

Check all allowable wastes that are contained within this load:

NOTE: Waste disposal at the Area 6 Hydrocarbon Landfill must have come into contact with petroleum hydrocarbons or coolants, such as: gasoline (no benzene, lead); jet fuel; diesel fuel; lubricants and hydraulics; kerosene; asphaltic petroleum hydrocarbon; and ethylene glycol.
Acceptable waste at any NTS landfill
$\square$ Asphalt $\otimes$ Metal
$\square$ Wood
$\square$ Paper
$\square$ Soil
$\square$ Rocks / unaltered geologic materials
Empty containers
$\square$ Plastic . $\square$ Wire
$\square$ Cable
$\square$ Cloth
$\square$ Rubber (excluding tires)
$\square$ Insulation (non-Asbestosform)
$\square$ Demolition debris
1 Manufactured iterns; (swamp coolers, furniture, rugs, carpet, electronic components, PPE, etc.)
Additional waste accepted at the Area 23 Mercury Landfill: $\square$ Office Waste $\square$ Food Waste
$\square$ Asbestos $\square$ Friable $\square$ Non-Friable (contact SWO if regulated load) Quantity:

Additional waste accepted at the Area 9 U10c Landfill:
$\square$ Non-friable asbestos
$\square$ Drained automobiles and military vehicles
$\square$ Light ballasts (contact swo)
Drained fuel filters (gas \& diesel)
Solid fractions from sand/oil/water
Hydrocarbons (contace SwO)
Other 3 empty steel drums (2x55; $1 \times 10)$
$\square$ Deconned Underground and Above Ground Tanks

Additional waste accepted at the Area 6 Hydrocarbon Landfill:
$\square$ Septic sludge
$\square$ Rags
Soil
$\square$ Drained fuel filters (gas \& diesel)
$\square$ Sludge from sand/oil/water separators REQUIRED: WIISTE GENERATOR SIGNATURE
Crushed non-teme plated oil tilters
PCBs below 50 parts per million
$\square$ Plants

Initials: (if initialed, no radiological clearance is necessary.)

The above mentioned waste was generated outside of is Controlled Waste Manageme knowledge, does not contain radiological materials.

To the best of my knowledge, the waste described above contains only thase materit site. I have verified this through the waste characterizetion method identified above. prohibited and allowable waste items. I have contacted Property Management and hi is approved for disposal in the landfill.

Print Name: John $\mathrm{F}$, Fow lo

Signature: _/S/ John M. Fowler

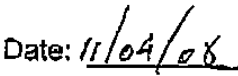

Radlologital Survey Reloase for Waste Dlsposal RCT Intitials

- 7 This contalnerload meets the criterla for no added man-made radioactive maturial Thls container/losed meets the criteria for Radcon Manual Table 4.2 release ilmitt. This containerhoad ls exompt fron survey

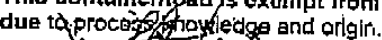

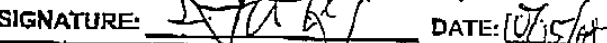

Note: "Food waste, office trash and animal carcasses do not require a radiological clearance. Freon-containing appliances must have signed removal certification statement with Load Verification."

SWO USE ONLY

Load Weight (net from scale or estimate): 120

1.29109 Signature of Certifier; $/$ / David Ridgeway 
Form

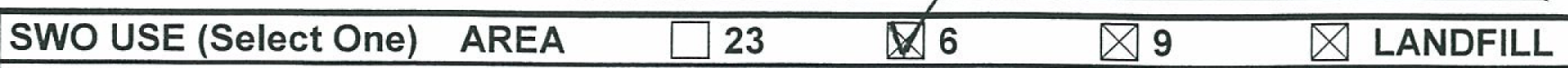

For waste characterization, approval, and/or assistance, contact Solid Waste Operation (SWO) at 5-7898.

REQUIRED: WASTE GERERATOR INFORMATION

(This form is for rolloffs, dump trucks, and other onsite disposal of materials.)

Waste Generator: Mark Heser (SNJV, WO) Phone Number: (o)5-2124; (c)496-0150 Location / Origin: CAU 130, CAS 20-99-05 - Container ID 130E0 - Tar residue

Waste Category: (check one)

Waste Type: $\square$ NTS

(check one)

$\square$ Non-Putrescible

$\square$ Commercial
$\square$ Putrescrible
$\square$ Asbestos Containing Material

$\triangle$ Industrial

$\triangle$ FFACO-onsite

Pollution Prevention Category: (check one) $\bigotimes$ Environmental management

Pollution Prevention Category: (check one)

$\triangle$ Clean-Up

Method of Characterization: (check one)

Sampling \& Analysis

$\square$ FFACO-offsite

$\square$ Defense Projects

ed at Area 7 CAS 07.0201

Prohibited Waste at all three

NTS landfills:

Additional Prohibited Waste

at the Area 9 U10C Landfill: Radioactive waste; RCRA waste; Hazardous waste; Free liquids, PCBs above TSCA regulatory
levels, and Medical wastes (needles, sharps, bloody clothing).

Sewage Sludge, Animal carcasses, Wet garbage (food waste); and Friable asbestos

\section{REQUIRED: WASTE CONTENTS ALLOWABLE WASTES}

Check all allowable wastes that are contained within this load:

NOTE: Waste disposal at the Area 6 Hydrocarbon Landfill must have come into contact with petroleum hydrocarbons or coolants, such as: gasoline (no benzene, lead); jet fuel; diesel fuel; lubricants and hydraulics; kerosene; asphaltic petroleum hydrocarbon; and ethylene glycol.
Acceptable waste at any NTS landfill: $\quad \square$ Paper
$\triangle$ Asphalt
$\square$ Metal
$\square$ Wood
$\square$ Soil
$\square$ Rocks / unaltered geologic materials
$\square$ Rubber (excluding tires)
$\square$ Plastic
Wire
$\square$ Cable
$\square$ Cloth
$\square$ Insulation (non-Asbestosform)
$\square$ Empty containers
$\square$ Demolition debris
$\square$ Cement \& concrete

$\square$ Manufactured items: (swamp coolers, furniture, rugs, carpet, electronic components, PPE, etc.)
Additional waste accepted at the Area 23 Mercury Landfill:
$\square$ Food Waste
Animal Carcasses
Office Waste

$\square$ Asbestos

Friable

Additional waste accepted at the Area $9 \mathrm{U} 10 \mathrm{c}$ Landfill:
$\square$ Non-friable asbestos
$\square$ Drained automobiles and military vehicles
Light ballasts (contact SWO)
$\square$ Drained fuel filters (gas \& diesel)
$\triangle$ Hydrocarbons (contact SWO)
$\triangle$ Other Coal Tar Epoxy Resin

Quantity:

Solid fractions from sand/oil/water

Deconned Underground and Above Ground Tanks

Additional waste accepted at the Area 6 Hydrocarbon Landfill: $\square \quad$ Coal Tar Epoxy Resin
$\square$ Septic sludge $\square$ Rags $\square$ Drained fuel filters (gas \& diesel)
$\square$ Crushed non-teme plated oil filters
Plants
$\square$ Soil
$\square$ Sludge from sand/oil/water separators
REQUIRED: WASTE GENERATOR SIGNATURE

Initials: (if initialed, no radiological clearance is necessary.)

The above mentioned waste was generated outside of a Controlled Waste Managem knowledge, does not contain radiological materials.

To the best of my knowledge, the waste described above contains only those materi site. I have verified this through the waste characterization method identified above prohibited and allowable waste items. I have contacted Property Management and $h$ is approved for disposal in the landfill.

Print Name: John M. Fow/2

Signature: Is/ John M. Fowler

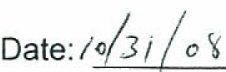

Radiological Survey Release for Waste Disposal RCT Initials

X This container/load meets the criteria for no added man-made radioactive material This container/load meets the criteria for Radcon Manual Table 4.2 release limits. This container//oad, is exempt from survey due to process/knowledae and origin.

Signature:/s/ Chao-Hsiung Tungate: $1 / 15 / 08$

Note: "Food waste, office trash and animal carcasses do not require a radiological clearance. Freon-containing appliances must have signed removal certification statement with Load Verification."

SWO USE ONLY

Load Weight (net from scale or estimate) $1501 \mathrm{~b}$ $12 / 10 / 08$ Signature of Certifier: /s/ Bart Burgess 


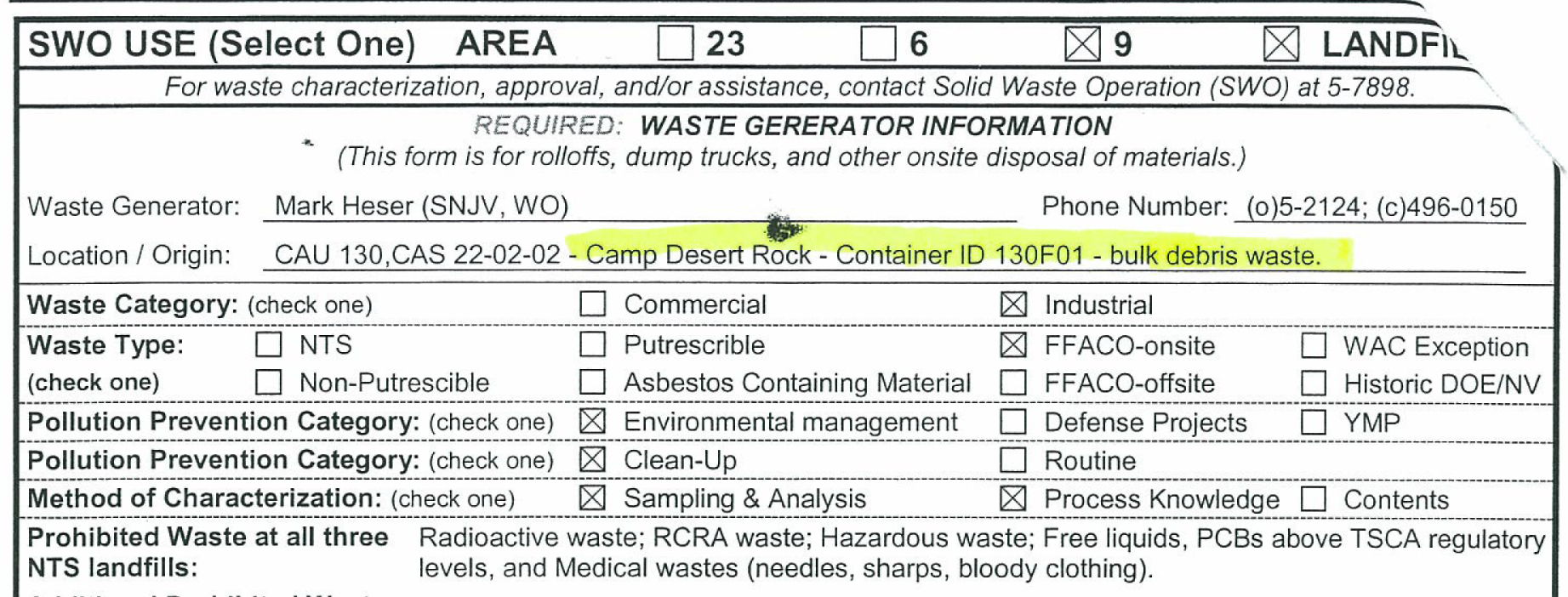

Additional Prohibited Waste at the Area 9 U10C Landfill:

Sewage Sludge, Animal carcasses, Wet garbage (food waste); and Friable asbestos

REQUIRED: WASTE CONTENTS ALLOWABLE WASTES

Check all allowable wastes that are contained within this load:

NOTE: Waste disposal at the Area 6 Hydrocarbon Landfill must have come into contact with petroleum hydrocarbons or coolants, such as: gasoline (no benzene, lead); jet fuel; diesel fuel; lubricants and hydraulics; kerosene; asphaltic petroleum hydrocarbon; and ethylene glycol.
Acceptable waste at any NTS landfill:
$\square$ Paper
$\square$ Rocks / unaltered geologic materials
$\square$ Soil
$\square$ Rubber (excluding tires)
$\square$ Insulation (non-Asbestosform)
Empty containers
$\bigotimes$ Asphalt $\quad$ Metal $\square$ Wood
$\square$ Cloth
Cable

et,

Manufactured items: (swamp coolers, furniture, rugs, carpet,

electronic components, PPE, etc.)

Additional waste accepted at the Area 23 Mercury Landfill: $\quad \square$ Office Waste $\square$ Food Was

$\square$ Asbestos $\quad \square$ Friable $\quad \square$ Non-Friable (contact SWO if regulated load) Quantity:

Additional waste accepted at the Area 9 U10c Landfill:
$\square$ Non-friable asbestos
Drained automobiles and military vehicles
Solid fractions from sand/oil/water
$\square$ Light ballasts (contact SWO)
Drained fuel filters (gas \& diesel)
Deconned Underground and Above
Hydrocarbons (contact SWO)
Other Piping - glavanized \& carbon steel
Ground Tanks

\begin{tabular}{|c|c|c|c|}
\hline \multicolumn{4}{|c|}{ Additional waste accepted at the Area 6 Hydrocarbon Landfill: } \\
\hline$\square$ Septic sludge & $\square$ Rags & $\square$ Drained fuel filters (gas \& diesel) & $\square$ Crushed non-teme plated oil filters \\
\hline$\square$ Plants & $\square$ Soil & $\square$ Sludge from sand/oil/water separators & $\square$ PCBs below 50 parts per million \\
\hline
\end{tabular}

Initials: (if initialed, no radiological clearance is necessary.)

The above mentioned waste was generated outside of a Controlled Waste Management Area (CWMA) and to the best of my knowledge, does not contain radiological materials.

To the best of my knowledge, the waste described above contains only those $m$ site. I have verified this through the waste characterization method identified a prohibited and allowable waste items. I have contacted Property Management : is approved for disposal in the landfill.

Print Name: Joha P. Fow

Signature: Is/ John M. Fowler Date:

Radiological Survey Release for Waste Disposal RCT Initials

This container/load meets the criteria for no added man-made radioactive material This container/load meets the criteria for Radcon Manual Table 4.2 release limits. This container/load is exempt from survey due to process knowredge and origin.

Note: "Food waste, office trash and animal carcasses do not require a radiologic must have signed removal certification statement with Load Verification."

SWO USE ONLY

Load Weight (net from scale or estimate):

\section{$11 / 3 / 08$}

Signature of Certifier: /s/ Don Bickford 


\section{\begin{tabular}{|l|llll}
\hline SWO USE (Select One) AREA & $\square 23$ & $\square 6$ & - 9 9
\end{tabular} \\ For waste characterization, approval, and/or assistance, contact Solid Waste Operation (SWO) at 5-7898. \\ REQUIRED; WASTE GERERATOR INFORMATION \\ (This fom is for rolloffs, dump trucks, and other onsite disposal of materials.)}

Waste Generator; Mark Heser (SNJV, WO): M/S 505

Phone Number: (0)5-2124: (c)496-0150

Location / Origin: CAU 130. CAS 07-02-01, No Container IDs - site restoration debris waste (4x4 posts, tarp. sand bags).

Waste Category: (check one)

Waste Type: 口NTS

Pollution Prevention Catostos Containing Material

$\triangle$ Industrial

Pollution Prevention Category: (check one) $Q$ Environmental management

Pollution Prevention Category: (check one) $\triangle$ Clean-Up

Method of Characterization: (check one)

$\square$ Sampling \& Analysis

$\triangle$ FFACO-Dnsite

$\square$ WAC Exception

$\square$ FFACO-offsite

[] Historic DOE/NV

$\square$ Defense Projects

YMP

Prohibited Waste at all three

NTS landfills:

Additional Prohibited Waste

at the Area 9 U10C Landfill:

¿ Process Knowledge $\otimes$ Contents

levels, and Medical wastes (needles, sharps, bloody clothing).

Sewage Sludge, Animal carcasses, Wet garbage (food waste); and Friable asbestos

\section{REQUIRED: WASTTE CONTENTS ALLOWABLE WASTES}

Check all allowable wastes that are contained within this load:

NOTE: Waste disposal at the Area 6 Hydrocarbon Landfill must have come into contact with petroleum hydrocarbons or coolants, such as: gasoline (no benzene, lead); jet fuel; diesel fuel; lubricants and hydraulics; kerosene; asphaltic petroleum hydrocarbon; and ethylene glycol.
Acceptable waste at any NTS landfill:
$\square$ Asphalt
Metal
Wood
$\square$ Paper
$\triangle$ Soil
Q Plastic
Wire
Cable
$\bigotimes$ Cloth
$\square$ Rocks / unaitered geologic materials
$\square$ Empty containers
$\square$ Rubber (excluding tires)
$\square$ Demolition debris
Manufactured items: (swamp
1 Cement \& concrete
$\square$ Asbestos
$\square$ Friable
Area 23 Merculy Landfill:
$\square$ Office Waste
Food Waste
Additional waste accepted at the Area 9 U10c Landfill:
$\square$ Non-friable asbestos
$\square$ Drained automobiles and military vehicles
Light ballasts (contact SWO)
Hydracarbons (contact SwO)
$\square$ Drained fuel filters (gas \& diesel)
Other
Quantity:
Solid tractions from sand/oil/water
$\square$ Deconned Underground and Above Ground Tanks

Animal Carcasses

Additional waste accepted at the Area 6 Hydracerbon Landfill:
I] Septic sludige
$\square$ Rags
Plants
Soil
$\square$ Drained juel filters (gas \& diesel)
$\square$ sludge from sand/oil/water separators REQUIRED: WASTE GENERATOR SIGNATURE
Crushed non-teme plated oil filters PCBs below 50 parts per million

Initials: ___ (if initialed, no radiological clearance is necessary.)

The above mentioned wasto was generated outside of a Controlled Waste Managemer knowledge, does not contain radiological materials.

To the best of my knowledge, the waste descrlbed above contains only those materia site. I have verified this through the waste characterization method identified above prohibited and allowable waste items. I have contacted Property Management and ha is approved for disposal in the landfill.

Print Name: Nat/L

Signature: /s/ Mark Heser

Note: "Food waste, offlce trash and animate: $2 / 25 / 04$ must have signed removal certification statems do not requíre a radiological clearance. Freon-containing appliances SWO USE ONLY Load Weight (net from scale orestimate). 250

\section{$2 / 26 / 09$}

Signature of Certiîer /s/Don Bickford
Radiological Survey Release for Westo Disposal RCY Initlals

- Thls contoiner/load moats the crltcriat for $\mathrm{n}$ added mari-made radloactive materlal Thls cantainer/load moetn the critoria for Radicon Manual Table 4,z release IImits. This containesiloadils sxampt from survey

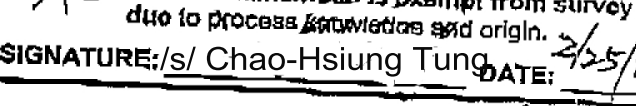
SIGNATURE:/S/ Chao-Hsiung TungaTE: $3 / 2,5 / 8$ 


\section{Appendix F}

\section{Modifications to the Post-Closure Plan}




\section{F.1.0 Modifications to the Post-Closure Plan}

This section does not apply to CAU 130 . 


\section{Appendix G}

\section{Use Restrictions}




\section{G.1.0 Use Restrictions}

This section does not apply to CAU 130 . 


\section{Appendix $\mathrm{H}$}

\section{Risk Evaluation}




\section{H.1.0 Risk Assessment}

The RBCA process used to establish FALs is described in the Industrial Sites Project Establishment of Final Action Levels (NNSA/NSO, 2006). This process conforms with NAC Section 445A.227, which lists the requirements for sites with soil contamination (NAC, 2006a). For the evaluation of corrective actions, NAC Section 445A.22705 (NAC, 2006b) recommends the use of ASTM Method E 1739-95 (ASTM, 1995) to "conduct an evaluation of the site, based on the risk it poses to public health and the environment, to determine the necessary remediation standards (i.e., FALs) or to establish that corrective action is not necessary.”

As defined in the DQOs, the presence of a COC would require corrective action. The evaluation of the need for corrective action also includes the potential for wastes that are present at a site to cause the future contamination of site environmental media if the wastes were to be released.

This section contains documentation of the RBCA process used to establish FALs described in the Industrial Sites Project Establishment of Final Action Levels (NNSA/NSO, 2006). This process defines three tiers (or levels) to establish FALs used to evaluate DQO decisions:

- $\quad$ Tier 1 - Sample results from source areas (highest concentrations) compared to risk-based screening levels (RBSLs) (i.e., PALs) based on generic (non-site-specific) conditions.

- $\quad$ Tier 2 - Sample results from exposure points compared to site-specific target levels (SSTLs) calculated using site-specific inputs and Tier 1 formulas.

- Tier 3 - Sample results from exposure points compared to SSTLs and points of compliance calculated using chemical fate/transport and probabilistic modeling.

The RBCA decision process stipulated in the Industrial Sites Project Establishment of Final Action Levels (NNSA/NSO, 2006) is summarized in Figure H.1-1. 


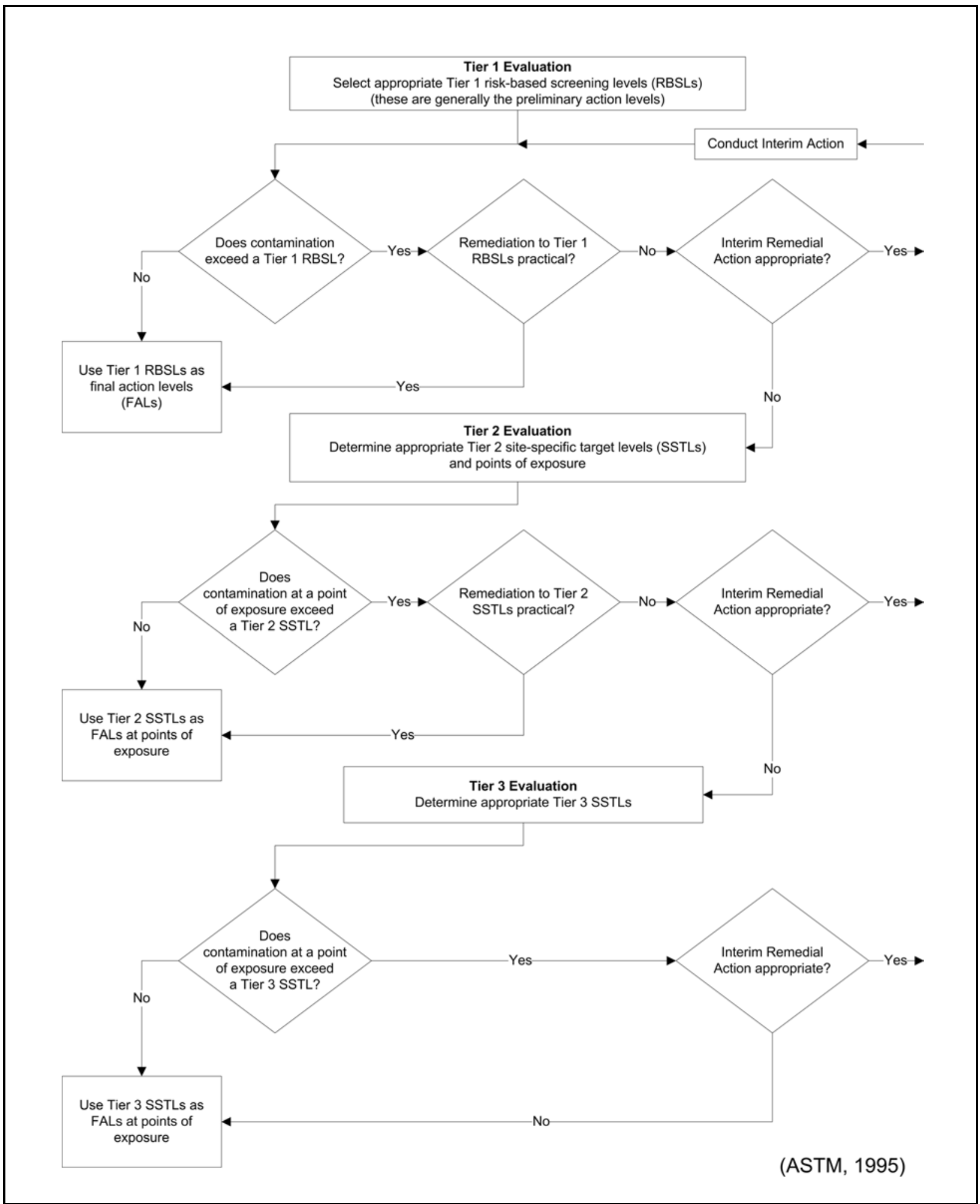

Figure H.1-1

Risk-Based Corrective Action Decision Process 


\section{H.1.1 A. Scenario}

Corrective Action Unit 130, Storage Tanks, consists of the following seven inactive CASs:

\section{CAS 01-02-01, Underground Storage Tank}

Corrective Action Site 01-02-01 was an abandoned site that consisted of a potential release associated with a UST. This site is located within the Apple II Historic District, between Buildings 1-31.1e1 and 1-31.4b1 in Area 1 of the NTS. This site has no operating status at this time.

\section{CAS 07-02-01, Underground Storage Tanks}

Corrective Action Site 07-02-01 was an abandoned site that consisted of a potential release associated with USTs. This site is located in Area 7 of the NTS, east of the T7c atmospheric test site. The CAS location is at an instrumentation shelter area, which includes Station 7-235. This site has no operating status at this time.

\section{CAS 10-02-01, Underground Storage Tank}

Corrective Action Site 10-02-01 was an abandoned site that consisted of a potential release from a UST. This site is located in Area 10 of the NTS, adjacent to the U10x crater. This CAS location may have been affiliated with nuclear testing in the area. This site has no operating status at this time.

\section{CAS 20-02-03, Underground Storage Tank}

Corrective Action Site 20-02-03 was an abandoned site that consisted of a potential release from a UST. This site is located in Area 20 of the NTS, adjacent to the U20az post-test cellar. This CAS is associated with the post-test gas sampling operations. This site has no operating status at this time.

\section{CAS 20-99-05, Tar Residue}

Corrective Action Site 20-99-05 was an abandoned site that consisted of a potential release from tar residue. This site is located in Area 20 of the NTS, adjacent to the U20z crater. This site has no operating status at this time. 


\section{CAS 22-02-02, Buried UST Piping}

Corrective Action Site 22-02-02 was an abandoned site that consisted of a potential release from buried UST piping. This site is located in Area 22 of the NTS at the former Camp Desert Rock. This site has no operating status at this time.

\section{CAS 23-02-07, Underground Storage Tank}

Corrective Action Site 23-02-07 consisted of a potential release from a UST. This site is located in Area 23 of the NTS, at a former vehicle maintenance shop. The potential UST was registered as closed with the State of Nevada. This site has no operating status at this time.

\section{H.1.2 B. Site Assessment}

The site assessment and correction action activities were conducted in accordance with the requirements set forth in the CAU 130 SAFER Plan (NNSA/NSO, 2008). Corrective Action Unit 130, Storage Tanks, consists of the following initial visual site assessments at the seven inactive CASs:

\section{CAS 01-02-01, Underground Storage Tank}

The CAS 01-02-01 visual assessment consisted of a 6-in. covered metal pipe at ground surface with a lid that reads "GAS."

\section{CAS 07-02-01, Underground Storage Tanks}

The CAS 07-02-01 visual assessment consisted of a sign and portal opening designating Station 7-235; lead bricks on the ground surface; earthen mounds; and pieces of debris including wood, metal, and wire.

\section{CAS 10-02-01, Underground Storage Tank}

The CAS 10-02-01 visual assessment consisted of three pipes extending from the ground surface. 


\section{CAS 20-02-03, Underground Storage Tank}

The CAS 20-02-03 visual assessment consisted of an earthen mound that correlates with the potential location of a UST.

\section{CAS 20-99-05, Tar Residue}

The CAS 20-99-05 visual assessment consisted of an approximate area of 40-by-30-ft scattered and broken pieces of a tar-like residue. The soils appeared to have some staining.

\section{CAS 22-02-02, Buried UST Piping}

The CAS 22-02-02 visual assessment consisted of a concrete island that may have been a fill station, and a concrete foundation that may have been a control room. Visible staining and debris including burned wood and small-diameter conduit was found inside the foundation.

\section{CAS 23-02-07, Underground Storage Tank}

The CAS 23-02-07 visual assessment consisted of an abandoned wooden platform; a concrete slab that may have been the former maintenance shop; and debris that included wire, wood, glass, and sandbags.

Table H.1-1 lists the CAI activities conducted at each CAS. Results of the CAI sampling data demonstrate that no COCs are present, and no further corrective action is necessary at any CAU 130 CAS.

The maximum concentration of contaminants identified at each CAS, and their corresponding PALs, are presented in Tables H.1-2 through H.1-8. 
Table H.1-1

CAI Activities Conducted at Each CAS To Meet SAFER Plan Requirements for CAU 130

\begin{tabular}{|c|c|c|c|c|c|c|c|}
\hline \multirow[b]{2}{*}{ CAl Activities } & \multicolumn{7}{|c|}{ CAS } \\
\hline & 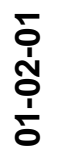 & $\begin{array}{l}\text {-' } \\
\stackrel{1}{N} \\
\text { N } \\
\stackrel{1}{0}\end{array}$ & $\begin{array}{l}\text { 엄 } \\
\text { ஸे } \\
\text { ò } \\
\text { ò }\end{array}$ & 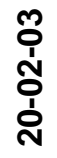 & $\begin{array}{l}\text { L } \\
\text { ơ } \\
\text { S̆ } \\
\text { ơ }\end{array}$ & $\begin{array}{l}\text { N } \\
\stackrel{1}{ } \\
\text { ஸे } \\
\stackrel{1}{N}\end{array}$ & 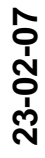 \\
\hline Inspected and verified the CAS components identified in the SAFER Plan. & $\mathrm{X}$ & $\mathrm{X}$ & $\mathrm{X}$ & $\mathrm{X}$ & $\mathrm{X}$ & $\mathrm{X}$ & $\mathrm{X}$ \\
\hline Performed site walkovers to identify biased sampling locations. & $\mathrm{X}$ & $\mathrm{X}$ & $\mathrm{X}$ & $\mathrm{X}$ & $\mathrm{X}$ & $\mathrm{X}$ & $x$ \\
\hline Conducted surface radiological surveys. & $x$ & $x$ & $x$ & $\mathrm{x}$ & $x$ & $x$ & -- \\
\hline Performed site transects/walkover surveys. & $\mathrm{X}$ & $x$ & $x$ & $x$ & -- & -- & -- \\
\hline Conducted geophysical/utility surveys. & $\mathrm{x}$ & $x$ & $\mathrm{X}$ & $\mathrm{x}$ & -- & $x$ & $\mathrm{x}$ \\
\hline Performed video investigation. & -- & $X$ & -- & -- & -- & -- & -- \\
\hline Collected biased soil samples. & $\mathrm{X}$ & $x$ & $x$ & $\mathrm{X}$ & $\mathrm{X}$ & $x$ & $x$ \\
\hline Field screened samples for alpha and beta/gamma radiation. & $\mathrm{X}$ & $\mathrm{X}$ & $\mathrm{X}$ & $\mathrm{X}$ & $\mathrm{X}$ & $\mathrm{X}$ & $\mathrm{X}$ \\
\hline Collected samples for waste characterization. & -- & $\mathrm{X}$ & $\mathrm{X}$ & -- & $\mathrm{X}$ & -- & $\mathrm{X}$ \\
\hline Collected swipe samples for removable activity determination. & -- & $\mathrm{X}$ & $\mathrm{X}$ & -- & $\mathrm{X}$ & $\mathrm{X}$ & -- \\
\hline Submitted select samples for offsite laboratory analysis. & $\mathrm{X}$ & $X$ & $\mathrm{X}$ & $\mathrm{X}$ & $\mathrm{X}$ & $\mathrm{X}$ & $x$ \\
\hline Collected GPS coordinates for sample locations and points of interest. & $\mathrm{X}$ & $\mathrm{X}$ & $\mathrm{X}$ & $\mathrm{X}$ & $\mathrm{X}$ & $\mathrm{X}$ & $\mathrm{X}$ \\
\hline
\end{tabular}

-- = Not applicable

Table H.1-2

Maximum Concentration of Detected Contaminants for CAS 01-02-01, Underground Storage Tank

(Page 1 of 2)

\begin{tabular}{|c|c|c|c|c|c|c|}
\hline Contaminant & $\begin{array}{c}\text { Maximum } \\
\text { Result }\end{array}$ & $\begin{array}{c}\text { Sample } \\
\text { Number }\end{array}$ & $\begin{array}{c}\text { Depth } \\
\text { (ft bgs) }\end{array}$ & Location & PAL Units \\
\hline \hline Ac-228 & 1.46 & $130 A 004$ & $3.0-3.5$ & A03 & 5 & $\mathrm{pCi} / \mathrm{g}$ \\
\hline Am-241 & $0.37(\mathrm{~J})$ & $130 \mathrm{~A} 001$ & $0.0-0.5$ & $\mathrm{~A} 01$ & 12.7 & $\mathrm{pCi} / \mathrm{g}$ \\
\hline Arsenic & 5 & $130 \mathrm{~A} 004$ & $3.0-3.5$ & $\mathrm{~A} 03$ & 23 & $\mathrm{mg} / \mathrm{kg}$ \\
\hline Barium & 190 & $130 \mathrm{~A} 003$ & $2.5-3.0$ & $\mathrm{~A} 02$ & 67,000 & $\mathrm{mg} / \mathrm{kg}$ \\
\hline Cadmium & 0.24 & $130 \mathrm{~A} 004$ & $3.0-3.5$ & $\mathrm{~A} 03$ & 450 & $\mathrm{mg} / \mathrm{kg}$ \\
\hline Chromium & 6.8 & $130 \mathrm{A001}$ & $0.0-0.5$ & $\mathrm{~A} 01$ & 450 & $\mathrm{mg} / \mathrm{kg}$ \\
\hline DRO & $4.8(\mathrm{~J})$ & $130 \mathrm{~A} 004$ & $3.0-3.5$ & A03 & 100 & $\mathrm{mg} / \mathrm{kg}$ \\
\hline
\end{tabular}


Table H.1-2

Maximum Concentration of Detected Contaminants for CAS 01-02-01, Underground Storage Tank

(Page 2 of 2)

\begin{tabular}{|c|c|c|c|c|c|c||}
\hline Contaminant & $\begin{array}{c}\text { Maximum } \\
\text { Result }\end{array}$ & $\begin{array}{c}\text { Sample } \\
\text { Number }\end{array}$ & $\begin{array}{c}\text { Depth } \\
\text { (ft bgs) }\end{array}$ & Location & PAL & Units \\
\hline \hline Fluoranthene & $0.1(\mathrm{~J})$ & $130 \mathrm{~A} 003$ & $2.5-3.0$ & $\mathrm{~A} 02$ & 22,000 & $\mathrm{mg} / \mathrm{kg}$ \\
\hline $\mathrm{Lead}$ & $11(\mathrm{~J})$ & $130 \mathrm{~A} 001$ & $0.0-0.5$ & $\mathrm{~A} 01$ & 800 & $\mathrm{mg} / \mathrm{kg}$ \\
\hline $\mathrm{Pb}-212$ & $1.79(\mathrm{~J})$ & $130 \mathrm{~A} 004$ & $3.0-3.5$ & $\mathrm{~A} 03$ & 5 & $\mathrm{pCi} / \mathrm{g}$ \\
\hline $\mathrm{Pb}-214$ & $1.28(\mathrm{~J})$ & $130 \mathrm{~A} 002$ & $2.5-3.0$ & $\mathrm{~A} 02$ & 5 & $\mathrm{pCi} / \mathrm{g}$ \\
\hline Mercury & $0.016(\mathrm{~J}+)$ & $130 \mathrm{~A} 003$ & $2.5-3.0$ & $\mathrm{~A} 02$ & 310 & $\mathrm{mg} / \mathrm{kg}$ \\
\hline Phenanthrene & $0.084(\mathrm{~J})$ & $130 \mathrm{~A} 003$ & $2.5-3.0$ & $\mathrm{~A} 02$ & 100,000 & $\mathrm{mg} / \mathrm{kg}$ \\
\hline Tl-208 & 0.58 & $130 \mathrm{~A} 001$ & $0.0-0.5$ & $\mathrm{~A} 01$ & 5 & $\mathrm{pCi} / \mathrm{g}$ \\
\hline
\end{tabular}

$\mathrm{J}=$ Estimated value

$\mathrm{J}+=$ The result is an estimated quantity, but the result may be biased high.

Table H.1-3

Maximum Concentration of Detected Contaminants for CAS 07-02-01, Underground Storage Tanks

(Page 1 of 2)

\begin{tabular}{|c|c|c|c|c|c|c||}
\hline Contaminant & $\begin{array}{c}\text { Maximum } \\
\text { Result }\end{array}$ & $\begin{array}{c}\text { Sample } \\
\text { Number }\end{array}$ & $\begin{array}{c}\text { Depth } \\
\text { (ft bgs) }\end{array}$ & Location & PAL & Units \\
\hline \hline Acetone & $0.013(\mathrm{~J})$ & $130 \mathrm{~B} 002$ & $0.0-0.5$ & $\mathrm{~B} 02$ & 54,000 & $\mathrm{mg} / \mathrm{kg}$ \\
\hline Ac-228 & 2.02 & $130 \mathrm{~B} 002$ & $0.0-0.5$ & $\mathrm{~B} 02$ & 5 & $\mathrm{pCi} / \mathrm{g}$ \\
\hline Am-241 & $1.18(\mathrm{~J})$ & $130 \mathrm{~B} 005$ & $3.0-3.5$ & $\mathrm{~B} 04$ & 12.7 & $\mathrm{pCi} / \mathrm{g}$ \\
\hline Aroclor 1254 & $0.054(\mathrm{~J})$ & $130 \mathrm{~B} 004$ & $0.5-1.0$ & $\mathrm{~B} 03$ & 0.74 & $\mathrm{mg} / \mathrm{kg}$ \\
\hline Arsenic & 5.3 & $130 \mathrm{~B} 001$ & $0.0-0.5$ & $\mathrm{~B} 01$ & 23 & $\mathrm{mg} / \mathrm{kg}$ \\
\hline Barium & 180 & $130 \mathrm{~B} 004$ & $0.5-1.0$ & $\mathrm{~B} 03$ & 67,000 & $\mathrm{mg} / \mathrm{kg}$ \\
\hline Cadmium & 0.19 & $130 \mathrm{~B} 001$ & $0.0-0.5$ & $\mathrm{~B} 01$ & 450 & $\mathrm{mg} / \mathrm{kg}$ \\
\hline Cs-137 & 1.16 & $130 \mathrm{~B} 005$ & $3.0-3.5$ & $\mathrm{~B} 04$ & 12.2 & $\mathrm{pCi} / \mathrm{g}$ \\
\hline Chromium & 10 & $130 \mathrm{~B} 001$ & $0.0-0.5$ & $\mathrm{~B} 01$ & 450 & $\mathrm{mg} / \mathrm{kg}$ \\
\hline DRO & $3.1(\mathrm{~J})$ & $130 \mathrm{~B} 001$ & $0.0-0.5$ & $\mathrm{~B} 01$ & 100 & $\mathrm{mg} / \mathrm{kg}$ \\
\hline Eu-152 & $2.61(\mathrm{~J})$ & $130 \mathrm{~B} 003$ & $0.0-0.5$ & $\mathrm{~B} 02$ & 5.67 & $\mathrm{pCi} / \mathrm{g}$ \\
\hline GRO & $0.13(\mathrm{~J})$ & $130 \mathrm{~B} 002$ & $0.0-0.5$ & $\mathrm{~B} 02$ & 100 & $\mathrm{mg} / \mathrm{kg}$ \\
\hline Lead & $220(\mathrm{~J})$ & $130 \mathrm{~B} 002$ & $0.0-0.5$ & $\mathrm{~B} 02$ & 800 & $\mathrm{mg} / \mathrm{kg}$ \\
\hline
\end{tabular}


Table H.1-3

Maximum Concentration of Detected Contaminants for CAS 07-02-01, Underground Storage Tanks (Page 2 of 2)

\begin{tabular}{|c|c|c|c|c|c|c||}
\hline Contaminant & $\begin{array}{c}\text { Maximum } \\
\text { Result }\end{array}$ & $\begin{array}{c}\text { Sample } \\
\text { Number }\end{array}$ & $\begin{array}{c}\text { Depth } \\
\text { (ft bgs) }\end{array}$ & Location & PAL & Units \\
\hline \hline $\mathrm{Pb}-212$ & $2.28(\mathrm{~J})$ & $130 \mathrm{~B} 002$ & $0.0-0.5$ & $\mathrm{~B} 02$ & 5 & $\mathrm{pCi} / \mathrm{g}$ \\
\hline $\mathrm{Pb}-214$ & $1.18(\mathrm{~J})$ & $130 \mathrm{~B} 003$ & $0.0-0.5$ & $\mathrm{~B} 02$ & 5 & $\mathrm{pCi} / \mathrm{g}$ \\
\hline Mercury & $0.031(\mathrm{~J}+)$ & $130 \mathrm{~B} 003$ & $0.0-0.5$ & $\mathrm{~B} 02$ & 310 & $\mathrm{mg} / \mathrm{kg}$ \\
\hline $\mathrm{Tl}-208$ & 0.63 & $130 \mathrm{~B} 002$ & $0.0-0.5$ & $\mathrm{~B} 02$ & 5 & $\mathrm{pCi} / \mathrm{g}$ \\
\hline
\end{tabular}

$\mathrm{J}=$ Estimated value

$\mathrm{J}+=$ The result is an estimated quantity, but the result may be biased high.

Table H.1-4

Maximum Concentration of Detected Contaminants for CAS 10-02-01, Underground Storage Tank

(Page 1 of 2)

\begin{tabular}{|c|c|c|c|c|c|c|}
\hline Contaminant & $\begin{array}{c}\text { Maximum } \\
\text { Result }\end{array}$ & $\begin{array}{l}\text { Sample } \\
\text { Number }\end{array}$ & $\begin{array}{l}\text { Depth } \\
\text { (ft bgs) }\end{array}$ & Location & PAL & Units \\
\hline Acetone & $0.0089(\mathrm{~J})$ & $130 \mathrm{C} 002$ & $0.0-0.5$ & $\mathrm{C02}$ & 54,000 & $\mathrm{mg} / \mathrm{kg}$ \\
\hline Ac-228 & 1.93 & $130 C 010$ & $8.0-8.5$ & C09 & 5 & $\mathrm{pCi} / \mathrm{g}$ \\
\hline Am-241 & $24.9(\mathrm{~J})$ & $130 C 006$ & $0.0-0.5$ & $\mathrm{C05}$ & 12.7 & $\mathrm{pCi} / \mathrm{g}$ \\
\hline Arsenic & 3.4 & $130 \mathrm{C} 002$ & $0.0-0.5$ & $\mathrm{CO2}$ & 23 & $\mathrm{mg} / \mathrm{kg}$ \\
\hline Barium & 150 & $130 C 010$ & $8.0-8.5$ & C09 & 67,000 & $\mathrm{mg} / \mathrm{kg}$ \\
\hline Bis(2-ethylhexyl)Phthalate & $0.29(\mathrm{~J})$ & $130 C 005$ & $0.0-0.5$ & $\mathrm{CO4}$ & 120 & $\mathrm{mg} / \mathrm{kg}$ \\
\hline Cs-137 & 40.1 & $130 C 006$ & $0.0-0.5$ & C05 & 12.2 & $\mathrm{pCi} / \mathrm{g}$ \\
\hline Chromium & $4.5(\mathrm{~J}+)$ & $130 \mathrm{C} 004$ & $0.0-0.5$ & $\mathrm{C03}$ & 450 & $\mathrm{mg} / \mathrm{kg}$ \\
\hline Co-60 & 0.69 & $130 C 006$ & $0.0-0.5$ & C05 & 2.68 & $\mathrm{pCi} / \mathrm{g}$ \\
\hline DRO & 8 & $130 \mathrm{C} 001$ & $0.0-0.5$ & $\mathrm{C01}$ & 100 & $\mathrm{mg} / \mathrm{kg}$ \\
\hline GRO & $0.46(\mathrm{~J})$ & $130 \mathrm{C} 007$ & $0.0-0.5$ & $\mathrm{C} 06$ & 100 & $\mathrm{mg} / \mathrm{kg}$ \\
\hline Lead & 19 & $130 C 008$ & $0.0-0.5$ & C07 & 800 & $\mathrm{mg} / \mathrm{kg}$ \\
\hline $\mathrm{Pb}-212$ & $1.97(\mathrm{~J})$ & $130 C 008$ & $0.0-0.5$ & $\mathrm{CO} 7$ & 5 & $\mathrm{pCi} / \mathrm{g}$ \\
\hline $\mathrm{Pb}-214$ & $1.22(\mathrm{~J})$ & $130 C 007$ & $0.0-0.5$ & C06 & 5 & $\mathrm{pCi} / \mathrm{g}$ \\
\hline Mercury & $0.021(\mathrm{~J}-)$ & $130 C 005$ & $0.0-0.5$ & $\mathrm{CO4}$ & 310 & $\mathrm{mg} / \mathrm{kg}$ \\
\hline
\end{tabular}


Table H.1-4

Maximum Concentration of Detected Contaminants for CAS 10-02-01, Underground Storage Tank (Page 2 of 2)

\begin{tabular}{|c|c|c|c|c|c|c||}
\hline Contaminant & $\begin{array}{c}\text { Maximum } \\
\text { Result }\end{array}$ & $\begin{array}{c}\text { Sample } \\
\text { Number }\end{array}$ & $\begin{array}{c}\text { Depth } \\
\text { (ft bgs) }\end{array}$ & Location & PAL & Units \\
\hline \hline Selenium & $0.68(\mathrm{~J}+)$ & $130 \mathrm{C} 008$ & $0.0-0.5$ & $\mathrm{C} 07$ & 5,100 & $\mathrm{mg} / \mathrm{kg}$ \\
\hline $\mathrm{Tl}-208$ & 0.7 & $130 \mathrm{C} 010$ & $8.0-8.5$ & $\mathrm{C} 09$ & 5 & $\mathrm{pCi} / \mathrm{g}$ \\
\hline
\end{tabular}

$\mathrm{J}=$ Estimated value

$\mathrm{J}+=$ The result is an estimated quantity, but the result may be biased high.

$\mathrm{J}-=$ The result is an estimated quantity, but the result may be biased low.

Table H.1-5

Maximum Concentration of Detected Contaminants for CAS 20-02-03, Underground Storage Tank

\begin{tabular}{|c|c|c|c|c|c|c|}
\hline Contaminant & $\begin{array}{c}\text { Maximum } \\
\text { Result }\end{array}$ & $\begin{array}{l}\text { Sample } \\
\text { Number }\end{array}$ & $\begin{array}{l}\text { Depth } \\
\text { (ft bgs) }\end{array}$ & Location & PAL & Units \\
\hline Ac-228 & 2.81 & 130D002 & $2.0-2.5$ & D01 & 5 & $\mathrm{pCi} / \mathrm{g}$ \\
\hline Arsenic & $3.9(\mathrm{~J})$ & 130D002 & $2.0-2.5$ & D01 & 23 & $\mathrm{mg} / \mathrm{kg}$ \\
\hline Barium & 220 & 130D001 & $2.0-2.5$ & D01 & 67,000 & $\mathrm{mg} / \mathrm{kg}$ \\
\hline Chromium & $5.6(\mathrm{~J})$ & 130D002 & $2.0-2.5$ & D01 & 450 & $\mathrm{mg} / \mathrm{kg}$ \\
\hline DRO & $3.2(\mathrm{~J})$ & 130D002 & $2.0-2.5$ & D01 & 100 & $\mathrm{mg} / \mathrm{kg}$ \\
\hline Lead & 10 & 130D002 & $2.0-2.5$ & D01 & 800 & $\mathrm{mg} / \mathrm{kg}$ \\
\hline Lead & 10 & 130D001 & $2.0-2.5$ & D01 & 800 & $\mathrm{mg} / \mathrm{kg}$ \\
\hline $\mathrm{Pb}-212$ & $2.99(\mathrm{~J})$ & 130D002 & $2.0-2.5$ & D01 & 5 & $\mathrm{pCi} / \mathrm{g}$ \\
\hline $\mathrm{Pb}-214$ & $1.76(\mathrm{~J})$ & 130D002 & $2.0-2.5$ & D01 & 5 & $\mathrm{pCi} / \mathrm{g}$ \\
\hline Mercury & $0.025(\mathrm{~J}-)$ & 130D002 & $2.0-2.5$ & D01 & 310 & $\mathrm{mg} / \mathrm{kg}$ \\
\hline Selenium & $0.71(\mathrm{~J}+)$ & 130D002 & $2.0-2.5$ & D01 & 5,100 & $\mathrm{mg} / \mathrm{kg}$ \\
\hline TI-208 & 0.95 & 130D002 & $2.0-2.5$ & D01 & 5 & $\mathrm{pCi} / \mathrm{g}$ \\
\hline Th-234 & $3.33(\mathrm{~J})$ & 130D002 & $2.0-2.5$ & D01 & 105 & $\mathrm{pCi} / \mathrm{g}$ \\
\hline
\end{tabular}

$\mathrm{J}=$ Estimated value

$\mathrm{J}+=$ The result is an estimated quantity, but the result may be biased high.

$\mathrm{J}-=$ The result is an estimated quantity, but the result may be biased low. 
Table H.1-6

Maximum Concentration of Detected

Contaminants for CAS 20-99-05, Tar Residue

\begin{tabular}{|c|c|c|c|c|c|c|}
\hline Contaminant & $\begin{array}{c}\text { Maximum } \\
\text { Result }\end{array}$ & $\begin{array}{l}\text { Sample } \\
\text { Number }\end{array}$ & $\begin{array}{l}\text { Depth } \\
\text { (ft bgs) }\end{array}$ & Location & PAL & Units \\
\hline Arsenic & $3.5(\mathrm{~J})$ & 130E001 & $0.0-0.5$ & E01 & 23 & $\mathrm{mg} / \mathrm{kg}$ \\
\hline Barium & 130 & 130E001 & $0.0-0.5$ & E01 & 67,000 & $\mathrm{mg} / \mathrm{kg}$ \\
\hline Barium & 130 & 130E002 & $0.0-0.5$ & E02 & 67,000 & $\mathrm{mg} / \mathrm{kg}$ \\
\hline Benzo(b)Fluoranthene & $0.089(\mathrm{~J})$ & 130E001 & $0.0-0.5$ & E01 & 2.1 & $\mathrm{mg} / \mathrm{kg}$ \\
\hline Chromium & $8(\mathrm{~J})$ & 130E001 & $0.0-0.5$ & E01 & 450 & $\mathrm{mg} / \mathrm{kg}$ \\
\hline Di-n-butyl Phthalate & $0.18(\mathrm{~J})$ & 130E001 & $0.0-0.5$ & E01 & 62,000 & $\mathrm{mg} / \mathrm{kg}$ \\
\hline DRO & $3.5(\mathrm{~J})$ & 130E001 & $0.0-0.5$ & E01 & 100 & $\mathrm{mg} / \mathrm{kg}$ \\
\hline Fluoranthene & $0.091(\mathrm{~J})$ & 130E001 & $0.0-0.5$ & E01 & 22,000 & $\mathrm{mg} / \mathrm{kg}$ \\
\hline Lead & 11 & 130E001 & $0.0-0.5$ & E01 & 800 & $\mathrm{mg} / \mathrm{kg}$ \\
\hline Mercury & $0.019(\mathrm{~J}-)$ & 130E001 & $0.0-0.5$ & E01 & 310 & $\mathrm{mg} / \mathrm{kg}$ \\
\hline Mercury & $0.019(\mathrm{~J}-)$ & 130E003 & $0.0-0.5$ & E02 & 310 & $\mathrm{mg} / \mathrm{kg}$ \\
\hline Pyrene & $0.079(\mathrm{~J})$ & 130E001 & $0.0-0.5$ & E01 & 29,000 & $\mathrm{mg} / \mathrm{kg}$ \\
\hline Selenium & $0.96(\mathrm{~J}+)$ & 130E002 & $0.0-0.5$ & E02 & 5,100 & $\mathrm{mg} / \mathrm{kg}$ \\
\hline
\end{tabular}

$\mathrm{J}=$ Estimated value

$\mathrm{J}+=$ The result is an estimated quantity, but the result may be biased high.

$\mathrm{J}-=$ The result is an estimated quantity, but the result may be biased low.

Table H.1-7

Maximum Concentration of Detected Contaminants for CAS 22-02-02, Buried UST Piping (Page 1 of 2)

\begin{tabular}{|c|c|c|c|c|c|c|}
\hline Contaminant & $\begin{array}{c}\text { Maximum } \\
\text { Result }\end{array}$ & $\begin{array}{c}\text { Sample } \\
\text { Number }\end{array}$ & $\begin{array}{c}\text { Depth } \\
\text { (ft bgs) }\end{array}$ & Location & PAL Units \\
\hline \hline Acetone & $0.019(\mathrm{~J})$ & $130 \mathrm{F001}$ & $0.0-0.5$ & $\mathrm{~F} 01$ & 54,000 & $\mathrm{mg} / \mathrm{kg}$ \\
\hline Ac-228 & 0.99 & $130 \mathrm{F002}$ & $2.0-2.5$ & $\mathrm{~F} 02$ & 5 & $\mathrm{pCi} / \mathrm{g}$ \\
\hline Arsenic & 6.3 & $130 \mathrm{F003}$ & $2.0-2.5$ & $\mathrm{~F} 02$ & 23 & $\mathrm{mg} / \mathrm{kg}$ \\
\hline Barium & 98 & $130 \mathrm{F002}$ & $2.0-2.5$ & $\mathrm{~F} 02$ & 67,000 & $\mathrm{mg} / \mathrm{kg}$ \\
\hline Bis(2-ethylhexyl)Phthalate & 0.35 & $130 \mathrm{F004}$ & $2.5-3.0$ & $\mathrm{~F} 03$ & 120 & $\mathrm{mg} / \mathrm{kg}$ \\
\hline Cadmium & $0.35(\mathrm{~J}-)$ & $130 \mathrm{~F} 003$ & $2.0-2.5$ & $\mathrm{~F} 02$ & 450 & $\mathrm{mg} / \mathrm{kg}$ \\
\hline Cadmium & 0.35 & $130 \mathrm{F004}$ & $2.5-3.0$ & $\mathrm{~F} 03$ & 450 & $\mathrm{mg} / \mathrm{kg}$ \\
\hline
\end{tabular}


Table H.1-7

Maximum Concentration of Detected

Contaminants for CAS 22-02-02, Buried UST Piping

(Page 2 of 2)

\begin{tabular}{|c|c|c|c|c|c|c|}
\hline Contaminant & $\begin{array}{l}\text { Maximum } \\
\text { Result }\end{array}$ & $\begin{array}{l}\text { Sample } \\
\text { Number }\end{array}$ & $\begin{array}{c}\text { Depth } \\
\text { (ft bgs) }\end{array}$ & Location & PAL & Units \\
\hline Chromium & 5.7 & 130F001 & $0.0-0.5$ & F01 & 450 & $\mathrm{mg} / \mathrm{kg}$ \\
\hline DRO & 9 & 130F003 & $2.0-2.5$ & $\mathrm{~F} 02$ & 100 & $\mathrm{mg} / \mathrm{kg}$ \\
\hline Lead & 110 & 130F003 & $2.0-2.5$ & $\mathrm{~F} 02$ & 800 & $\mathrm{mg} / \mathrm{kg}$ \\
\hline Lead & 110 & 130F002 & $2.0-2.5$ & $\mathrm{~F} 02$ & 800 & $\mathrm{mg} / \mathrm{kg}$ \\
\hline $\mathrm{Pb}-212$ & 0.82 & 130F002 & $2.0-2.5$ & $\mathrm{~F} 02$ & 5 & $\mathrm{pCi} / \mathrm{g}$ \\
\hline $\mathrm{Pb}-214$ & $0.69(\mathrm{~J})$ & 130F001 & $0.0-0.5$ & F01 & 5 & $\mathrm{pCi} / \mathrm{g}$ \\
\hline Mercury & 0.015 & 130F001 & $0.0-0.5$ & F01 & 310 & $\mathrm{mg} / \mathrm{kg}$ \\
\hline Methylene Chloride & $0.0028(\mathrm{~J})$ & 130F001 & $0.0-0.5$ & F01 & 21 & $\mathrm{mg} / \mathrm{kg}$ \\
\hline TI-208 & 0.282 & 130F004 & $2.5-3.0$ & F03 & 5 & $\mathrm{pCi} / \mathrm{g}$ \\
\hline
\end{tabular}

$\mathrm{J}=$ Estimated value

$\mathrm{J}-=$ The result is an estimated quantity, but the result may be biased low.

Table H.1-8

Maximum Concentration of Detected Contaminants for CAS 23-02-07, Underground Storage Tank

(Page 1 of 2)

\begin{tabular}{|c|c|c|c|c|c|c|}
\hline Contaminant & $\begin{array}{l}\text { Maximum } \\
\text { Result }\end{array}$ & $\begin{array}{l}\text { Sample } \\
\text { Number }\end{array}$ & $\begin{array}{c}\text { Depth } \\
\text { (ft bgs) }\end{array}$ & Location & PAL & Units \\
\hline 4,4'-DDT & $0.0057(\mathrm{~J})$ & 130G001 & $1.5-2.0$ & G01 & 7 & $\mathrm{mg} / \mathrm{kg}$ \\
\hline Acetone & $0.013(\mathrm{~J})$ & 130G001 & $1.5-2.0$ & G01 & 54,000 & $\mathrm{mg} / \mathrm{kg}$ \\
\hline Ac-228 & 1.3 & 130G004 & $8.0-8.5$ & G03 & 5 & $\mathrm{pCi} / \mathrm{g}$ \\
\hline Arsenic & 5.2 & 130G001 & $1.5-2.0$ & G01 & 23 & $\mathrm{mg} / \mathrm{kg}$ \\
\hline Barium & 330 & 130G004 & $8.0-8.5$ & G03 & 67,000 & $\mathrm{mg} / \mathrm{kg}$ \\
\hline Bis(2-ethylhexyl)Phthalate & $0.67(\mathrm{~J})$ & 130G001 & $1.5-2.0$ & G01 & 120 & $\mathrm{mg} / \mathrm{kg}$ \\
\hline Cadmium & $0.32(\mathrm{~J}-)$ & 130G001 & $1.5-2.0$ & G01 & 450 & $\mathrm{mg} / \mathrm{kg}$ \\
\hline Chlordane & $0.47(\mathrm{~J})$ & 130G001 & $1.5-2.0$ & G01 & 6.5 & $\mathrm{mg} / \mathrm{kg}$ \\
\hline Chromium & 7.6 & 130G001 & $1.5-2.0$ & G01 & 450 & $\mathrm{mg} / \mathrm{kg}$ \\
\hline DRO & 350 & 130G001 & $1.5-2.0$ & G01 & 100 & $\mathrm{mg} / \mathrm{kg}$ \\
\hline GRO & 0.54 & 130G001 & $1.5-2.0$ & G01 & 100 & $\mathrm{mg} / \mathrm{kg}$ \\
\hline
\end{tabular}


Table H.1-8

Maximum Concentration of Detected

Contaminants for CAS 23-02-07, Underground Storage Tank

(Page 2 of 2)

\begin{tabular}{||c|c|c|c|c|c|c||}
\hline Contaminant & $\begin{array}{c}\text { Maximum } \\
\text { Result }\end{array}$ & $\begin{array}{c}\text { Sample } \\
\text { Number }\end{array}$ & $\begin{array}{c}\text { Depth } \\
\text { (ft bgs) }\end{array}$ & Location & PAL & Units \\
\hline \hline Lead & 430 & $130 \mathrm{G} 001$ & $1.5-2.0$ & $\mathrm{G} 01$ & 800 & $\mathrm{mg} / \mathrm{kg}$ \\
\hline $\mathrm{Pb}-212$ & $1.24(\mathrm{~J})$ & $130 \mathrm{G} 004$ & $8.0-8.5$ & $\mathrm{G} 03$ & 5 & $\mathrm{pCi} / \mathrm{g}$ \\
\hline $\mathrm{Pb}-214$ & $0.99(\mathrm{~J})$ & $130 \mathrm{G} 004$ & $8.0-8.5$ & $\mathrm{G} 03$ & 5 & $\mathrm{pCi} / \mathrm{g}$ \\
\hline Mercury & 0.024 & $130 \mathrm{G} 001$ & $1.5-2.0$ & $\mathrm{G} 01$ & 310 & $\mathrm{mg} / \mathrm{kg}$ \\
\hline Methylene Chloride & $0.0031(\mathrm{~J})$ & $130 \mathrm{G} 004$ & $8.0-8.5$ & $\mathrm{G} 03$ & 21 & $\mathrm{mg} / \mathrm{kg}$ \\
\hline Tl-208 & 0.4 & $130 \mathrm{G} 004$ & $8.0-8.5$ & $\mathrm{G} 03$ & 5 & $\mathrm{pCi} / \mathrm{g}$ \\
\hline
\end{tabular}

$\mathrm{J}=$ Estimated value

$\mathrm{J}-=$ The result is an estimated quantity, but the result may be biased low.

\section{H.1.3 C. Site Classification and Initial Response Action}

The four major site classifications listed in Table 3 of the ASTM Standard are (1) immediate threat to human health, safety, and the environment; (2) short-term (0 to 2 years) threat to human health, safety, and the environment; (3) long-term (greater than 2 years) threat to human health, safety, or the environment; and (4) no demonstrated long-term threats.

Based on the CAI, none of the CASs present an immediate threat to human health, safety, and the environment; therefore, the only interim response actions was to remove the lead bricks from CAS 07-02-01. Based on this information, all CASs are determined to be Classification 4 sites except for CAS 07-02-01, which is determined as a Classification 3 site as defined by ASTM Method E 1739-95 (ASTM, 1995), and pose no demonstrated near- or long-term threats.

\section{H.1.4 D. Development of Tier 1 Lookup Table of RBSLs}

Tier 1 RSBLs have been defined as the PALs established during the DQO process. The PALs are a tabulation of chemical-specific (but not site-specific) screening levels based on the type of media (soil) and potential exposure scenarios (industrial). These are very conservative estimates of risk, are preliminary in nature, and are used as action levels for site screening purposes. Although the PALs are not intended to be used as FALs, a FAL may be defined as the Tier 1 action level (i.e., PAL) value 
if individual contaminant analytical results are below the corresponding Tier 1 action level value. The FAL may also be established as the Tier 1 action level value if individual contaminant analytical results exceed the corresponding Tier 1 action level value and implementing a corrective action based on the FAL is appropriate. The PALs are defined as:

- $\quad$ The EPA Region 9 Risk-Based Preliminary Remediation Goals (PRGs) for Industrial Soils (EPA, 2004).

- Background concentrations for RCRA metals will be evaluated when natural background exceeds the PAL, which is often the case with arsenic. Background is considered the mean plus two times the standard deviation of the mean based on data published in Mineral and Energy Resource Assessment of the Nellis Air Force Range (NBMG, 1998; Moore, 1999).

- The TPH concentrations above the action level of $100 \mathrm{mg} / \mathrm{kg}$ per NAC 445A.2272 (NAC, 2006c).

- The PALs for radioactive contaminants are based on the NCRP Report No. 129 recommended screening limits for construction, commercial, industrial land-use scenarios (NCRP, 1999) scaled to 25-millirem-per-year (mrem/yr) dose constraint (Appenzeller-Wing, 2004) and the generic guidelines for residual concentration of radionuclides in DOE Order 5400.5 (DOE, 1993).

The PALs were developed based on an industrial scenario. Because the CAU 130 CASs in Areas 1, 7, 10, 20, 22, and 23 are not assigned work stations and are considered to be in remote or occasional use areas, the use of industrial-reuse-based PALs is conservative. The Tier 1 lookup table is defined as the PAL concentrations or activities defined in the CAU 130 SAFER Plan (NNSA/NSO, 2008).

\section{H.1.5 E. Exposure Pathway Evaluation}

The DQOs stated that site workers would only be exposed to COCs through oral ingestion, inhalation, or dermal contact (absorption) due to exposure to potentially contaminated media (i.e., soil) at the CASs. The results of the CAI showed that no COCs were identified at CASs within CAU 130. Because no COCs were identified, the potential exposure pathways cannot result in worker contact with contaminated soil. The limited migration demonstrated by the analytical results, elapsed time since the suspected release, and depth to groundwater supports the selection and evaluation of only surface and shallow subsurface contact as the complete exposure pathways. Groundwater is not considered to be a significant exposure pathway. 


\section{H.1.6 F. Comparison of Site Conditions with Tier 1 RBSLs}

All analytical results from CAU 130 samples were less than corresponding Tier 1 action levels (i.e., PALs) except for those listed in Table H.1-9.

Table H.1-9

Maximum Reported Value for Tier 1 Comparison

\begin{tabular}{|c|c|c|c|c||}
\hline CAS & Contaminant & PAL & Units & $\begin{array}{c}\text { Maximum } \\
\text { Reported Value }\end{array}$ \\
\hline \hline $10-02-01$ & $\mathrm{Am}-241$ & 12.7 & $\mathrm{pCi} / \mathrm{g}$ & $24.9(\mathrm{~J})$ \\
\hline $10-02-01$ & $\mathrm{Cs}-137$ & 12.2 & $\mathrm{pCi} / \mathrm{g}$ & 40.1 \\
\hline $23-02-07$ & TPH-DRO & 100 & $\mathrm{mg} / \mathrm{kg}$ & 350 \\
\hline
\end{tabular}

$\mathrm{J}=$ Estimated value

Potential source material was identified at CAS 07-02-01 in the form of lead bricks. This resulted in a corrective action of clean closure for this CAS when the bricks were removed. Verification samples of the soil beneath the bricks demonstrated that remaining soils do not contain contamination exceeding Tier 1 RSBLs.

\section{H.1.7 G. Evaluation of Tier 1 Results}

For all contaminants at all CASs not listed in Table H.1-9, the FALs were established as the Tier 1 RBSLs. It was determined that NFA is required for these contaminants at these CASs.

It was determined by NNSA/NSO that remediation of the remaining contaminants listed in Table H.1-9 was not appropriate. Therefore, a Tier 2 SSTL will be calculated for these contaminants at these CASs.

\section{H.1.8 H. Tier 1 Remedial Action Evaluation}

No remedial actions will be conducted based on Tier 1 RBSLs.

\section{H.1.9 I. Tier 2 Evaluation}

No additional data were needed to complete a Tier 2 evaluation. 


\section{H.1.10 J. Development of Tier 2 SSTLS}

\section{Evaluation of Radiological Contaminant SSTLS}

The Tier 2 evaluation consisted of evaluating the radionuclides detected that exceeded Tier 1 levels. Two radionuclides, Am-241 and Cs-137, were found to exceed the PAL (Tier 1) levels at CAS 10-02-01. Therefore, the CAS-specific Tier 2 SSTLs were calculated using the RESRAD computer code (Yu et al., 2001) and site-specific parameters. The RESRAD calculations were based on continued industrial use of the site assuming that a worker will be on the site for 250 days per year, 10 hours per day for a duration of 25 years. The industrial worker scenario Tier 2 SSTL for Am-241 was established at $462 \mathrm{pCi} / \mathrm{g}$ and Cs-137 was established at $92.5 \mathrm{pCi} / \mathrm{g}$. A more detailed discussion of the RESRAD code, site-specific parameters used, and the printed RESRAD outputs are provided in Attachment 1 of this appendix.

\section{Evaluation of TPH-DRO SSTLS}

Method E 1739-95 stipulates that risk evaluations for TPH-DRO contamination be calculated and evaluated based on the risk posed by the potentially hazardous constituents of TPH-DRO. Section 6.4.3 (“Use of Total Petroleum Hydrocarbon Measurements”) of ASTM Method E 1739-95 states: "TPHs should not be used for risk assessment because the general measure of TPH-DRO provides insufficient information about the amounts of individual chemical(s) of concern present” (see also Sections X1.5.4 and X1.42 of Method E 1739-95 in ASTM [1995]). Therefore, the individual potentially hazardous constituents will be evaluated for risk in place of TPH-DRO. The SSTLs were established for the individual potentially hazardous constituents in TPH-DRO at the corresponding PAL concentrations. (Note: The PALs were based on an industrial use scenario in the SAFER [NNSA/NSO, 2008].) These SSTLs and the maximum reported level for each potentially hazardous constituent for each CAS where the TPH-DRO concentration exceeds $100 \mathrm{mg} / \mathrm{kg}$ are presented in Table H.1-10.

\section{H.1.11 K. Comparison of Site Conditions with Tier 2 SSTLs}

The Tier 2 action levels are typically compared to individual sample results from reasonable points of exposure (as opposed to the source areas as is done in Tier 2) on a point-by-point basis. Points of exposure are defined as those locations or areas at which an individual or population may come in 
Table H.1-10

Tier 2 SSTLs and CAU 130 Results for Hazardous Constituents of Diesel for Sample 130G001

\begin{tabular}{|c|c|c|}
\hline \multirow[t]{2}{*}{ Constituent } & \multirow{2}{*}{$\begin{array}{l}\text { SSTL } \\
\text { (mg/kg) }\end{array}$} & $\begin{array}{l}\text { Maximum Reported Value } \\
(\mathrm{mg} / \mathrm{kg})\end{array}$ \\
\hline & & 130G001 \\
\hline Benzo(a)Pyrene ${ }^{a}$ & 0.21 & $\mathrm{ND}^{\mathrm{a}}$ \\
\hline Benzene & 1.4 & ND \\
\hline Benzo(a)Anthracene & 2.1 & ND \\
\hline Benzo(b)Fluoranthene & 2.1 & ND \\
\hline Benzo(k)Fluoranthene & 21 & ND \\
\hline 1,3,5-Trimethylbenzene & 70 & ND \\
\hline Naphthalene & 190 & ND \\
\hline 2-Methylnaphthalene & 190 & ND \\
\hline Chrysene & 210 & ND \\
\hline n-Propylbenzene & 240 & ND \\
\hline n-Butylbenzene & 240 & ND \\
\hline Ethylbenzene & 400 & ND \\
\hline Total Xylenes $^{b}$ & 420 & ND \\
\hline Toluene & 520 & ND \\
\hline Fluoranthene & 22,000 & ND \\
\hline Fluorene & 26,000 & ND \\
\hline Benzo(g,h,i)Perylene & 29,000 & ND \\
\hline Pyrene & 29,000 & ND \\
\hline Anthracene & 100,000 & ND \\
\hline Phenanthrene & 100,000 & ND \\
\hline
\end{tabular}

${ }^{a}$ For clarification of the benzo(a)pyrene and dibenzo(a,h)anthracene, see Table 4-2 and Section 4.1.1.1.1, Completeness.

${ }^{\mathrm{b}}$ Combination of o-, $\mathrm{m}-$, and $\mathrm{p}$-xylene

$\mathrm{ND}=$ Nondetect

contact with a COC originating from a CAS. For CAU 130, the Tier 2 action level for Am-241 and Cs-137 were compared to maximum contaminant concentrations from each sample location. 
As shown in Table H.1-9, the maximum concentrations for Am-241 (24.9 pCi/g) and Cs-137 (40.1 pCi/g) at CAS 10-02-01 was less than the corresponding Tier 2 action level of $462 \mathrm{pCi} / \mathrm{g}$ and 92.5 pCi/g, respectively. Therefore, the FALs for Am-241 and Cs-137 at CAS 10-02-01 were established as the Tier 2 SSTLs.

Because more than one carcinogenic radionuclide (Am-241 and Cs-137) from CAS 10-02-01 exceeded PALs, a multiple constituent analysis was conducted to assess the cumulative carcinogenicity of those constituents at that CAS. This is done by summing the FAL fractions of each constituent. If the result is less than one, then the combined effect of the contaminants does not pose a significant concern with respect to their FALs. The maximum Am-214 concentration of $24.9 \mathrm{pCi} / \mathrm{g}$ equates to a fraction of 0.05 of the FAL (462 pCi/g), and the maximum Cs-137 concentration of $40.1 \mathrm{pCi} / \mathrm{g}$ equates to a fraction of 0.43 of the FAL $(92.5 \mathrm{pCi} / \mathrm{g})$. The sum of fractions resulted in a value of 0.48 , which is less than one and indicates that the combined effect of the two contaminants does not pose a significant concern with respect to their FALs.

No hazardous constituent of TPH-DRO as listed in Table H.1-10 exceeded its corresponding PAL. Therefore, the FALs for the hazardous constituents of TPH-DRO at CAS 23-02-07 were established as the corresponding PAL concentrations.

\section{H.1.12 L. Tier 2 Remedial Action Evaluation}

Based on the Tier 2 evaluation of Am-241 and Cs-137 at CAS 10-02-01, and the hazardous constituents of TPH-DRO at CAS 23-02-07, these contaminants do not exceed FALs and do not pose an unacceptable risk to human health and the environment. Therefore, NFA is necessary. As all contaminant FALs were established as Tier 1 or Tier 2 action levels, a Tier 3 evaluation was not considered necessary. 


\section{H.2.0 Recommendations}

Because all of the site contaminant concentrations in soils from the analysis of CAU 130 samples were less than the corresponding FALs at all locations, it was determined that contamination does not pose an unacceptable risk to human health, safety, or the environment at these locations; therefore, no further corrective actions are required. 


\section{H.3.0 References}

ASTM, see American Society for Testing and Materials.

American Society for Testing and Materials. 1995. Standard Guide for Risk-Based Corrective Action Applied at Petroleum Release Sites, ASTM E 1739-95 (Reapproved 2002). Philadelphia, PA.

Appenzeller-Wing, J., U.S. Department of Energy, National Nuclear Security Administration Nevada Site Office. 2004. Letter to T.A. Maize (NDEP) entitled, "Submittal of Proposed Radiological Preliminary Action Levels (PALs) for the Industrial Sites Project,” 15 January. Las Vegas, NV.

DOE, see U.S. Department of Energy.

EPA, see U.S. Environmental Protection Agency.

Moore, J., Science Applications International Corporation. 1999. Memorandum to M. Todd (SAIC), "Background Concentrations for NTS and TTR Soil Samples,” 3 February. Las Vegas, NV.

NAC, see Nevada Administrative Code.

NBMG, see Nevada Bureau of Mines and Geology.

NCRP, see National Council on Radiation Protection and Measurements.

NNSA/NSO, see U.S. Department of Energy, National Nuclear Security Administration Nevada Site Office.

National Council on Radiation Protection and Measurements. 1999. Recommended Screening Limits for Contaminated Surface Soil and Review of Factors Relevant to Site-Specific Studies, NCRP Report No. 129. Bethesda, MD.

Nevada Administrative Code. 2006a. NAC 445A.227, “Contamination of Soil: Order by Director for Corrective Action; Factors To Be Considered in Determining Whether Corrective Action Required.” Carson City, NV. As accessed at http://www.leg.state.nv.us/nac on 7 January 2008.

Nevada Administrative Code. 2006b. NAC 445A.22705, “Contamination of Soil: Evaluation of Site by Owner or Operator; Review of Evaluation by Division.” Carson City, NV. As accessed at http://www.leg.state.nv.us/nac on 7 January 2008.

Nevada Administrative Code. 2006c. NAC 445A.2272, "Contamination of Soil: Establishment of Action Levels.” Carson City, NV. As accessed at http://www.leg.state.nv.us/nac on 7 January 2008. 
Nevada Bureau of Mines and Geology. 1998. Mineral and Energy Resource Assessment of the Nellis Air Force Range, Open-File Report 98-1. Reno, NV.

U.S. Department of Energy. 1993. Radiation Protection of the Public and the Environment, DOE Order 5400.5, Change 2. Washington, DC.

U.S. Department of Energy, National Nuclear Security Administration Nevada Site Office. 2006. Industrial Sites Project Establishment of Final Action Levels, Rev. 0, DOE/NV--1107. Las Vegas, NV.

U.S. Department of Energy, National Nuclear Security Administration Nevada Site Office. 2008. Streamlined Approach for Environmental Restoration (SAFER) for Corrective Action Unit 130: Storage Tanks, Nevada Test Site, Nevada, Rev. 0, DOE/NV--1276. Las Vegas, NV.

U.S. Environmental Protection Agency. 2004. Region 9 Preliminary Remediation Goals (PRGs). As accessed at http://www.epa.gov/region09/waste/sfund/prg/index.htm on 7 January 2008. San Francisco, CA.

Yu, C., A.J. Zielen, J.J. Cheng, D.J. LePoire, E. Gnanapragasam, S. Kamboj, J. Arnish, A. Wallo III, W.A. Williams, and H. Peterson. 2001. User's Manual for RESRAD Version 6, ANL/EAD-4. Argonne, IL: Argonne National Laboratory, Environmental Assessment Division. (Version 6.4 released in December 2007.) 


\section{Attachment 1}

Derivation of Residual Radioactive Material Guidelines for Radionuclides in Soil at Corrective Action Unit 130, CAS 10-02-01, Storage Tanks, Nevada Test Site, Nevada

(14 pages) 
Derivation of Residual Radioactive Material Guidelines for Radionuclides in Soil at Corrective Action Unit (CAU) 130, Corrective Action Site (CAS) 10-02-01, Storage Tanks, Nevada Test Site, Nevada

December 2008

Prepared by:

Stoller-Navarro Joint Venture,

P.O. Box 98952

Las Vegas, Nevada 89193

Work sponsored by United States Department of Energy, National Nuclear Security Administration Nevada Site Office, Environmental Restoration Division, Las Vegas, Nevada 
Derivation of Residual Radioactive Material Guidelines for Radionuclides in Soil at Corrective Action Unit (CAU) 130, Corrective Action Site (CAS) 10-02-01, Storage Tanks, Nevada Test Site (NTS), Nevada

\subsection{Introduction}

The U.S. Department of Energy (DOE) and the DOE, National Nuclear Security Administration Nevada Site Office (NNSA/NSO) Environmental Restoration Division have numerous sites impacted from the development, testing, and production of nuclear weapons. These impacts can take the form of chemical and/or radiological contaminants. Similar to its approach for chemical contamination, NNSA/NSO is committed to properly evaluating, radiologically characterizing, and where appropriate, remediating these sites to ensure the doses to radiation workers and members of the public are maintained as low as reasonably achievable (ALARA), at a minimum, below the primary dose limits as stated in DOE Order 5400.5 (DOE, 1993).

To accomplish this, the potential for residual radioactive contamination in soils must be evaluated to determine the status of compliance with the requirements of DOE Order 5400.5 (DOE, 1993). The DOE Order 5400.5 requires that: "The Authorized Limits shall be established to (1) provide that, at a minimum, the basic dose limits ... will not be exceeded, or (2) be consistent with applicable generic guidelines." Because generic guidelines have not been established for volumetric residual radioactivity for the radionuclides of concern at CAU 130, CAS 10-02-01, Authorized Limits or final action levels (FALs) were derived using the Residual Radioactive (RESRAD) model and computer code (Yu et al., 2001). The goal of this effort was to produce Authorized Limits, in units of picocuries per gram ( $\mathrm{pCi} / \mathrm{g}$ ) in soil above background, for CAU 130, CAS 10-02-01, that would result in radiation doses less than 25 mrem per year (mrem/yr) to an industrial worker at the site.

To develop the FALs, a "realistic" yet conservative radiation dose analysis was conducted using approved exposure scenarios and site-specific data to determine the translation between surface soil concentrations and individual radiation doses. For this analysis, site-specific data included soil sampling results obtained during site investigation activities at CAU 130, CAS 10-02-01, and meteorological data obtained from the Air Resources Laboratory/Special Operations and Research Division (ARL/SORD). This report provides the radiation dose modeling analysis supporting the technical derivation of the Authorized Limits for CAU 130, CAS 10-02-01, Storage Tanks. This report also defines the radionuclides considered and approved exposure scenarios for the NTS, identifies the applicable exposure pathways and key input data or assumptions, presents the radiation doses for unit concentrations of radionuclides in soil, and establishes the FALs for CAU 130, CAS 10-02-01. 


\subsection{Site Closure Activities and Sample Results}

Radionuclides were found in the soil samples collected from CAS 10-02-01. The RESRAD calculations are based on validated analytical sample results obtained during site investigation activities and other applicable information specified in the CAU 130 Streamlined Approach for Environmental Restoration (SAFER) Plan (NNSA/NSO, 2008) Because the sampling was based on a biased sampling plan, RESRAD calculation uses the maximum value of the radionuclide found in the samples. Appendix B of the CAU 130 SAFER contains a detailed description of the sample results, analytical parameters, and laboratory methods used to analyze the soil samples. The maximum concentrations (including background) found at CAU 130, CAS 10-02-01, are listed in Table 2-1.

Table 2-1

Maximum Radionuclide Results Found in CAU 130, CAS 10-02-01, Soil Samples

\begin{tabular}{|c|c|c|}
\hline Radionuclide & Sample Number & Concentration (pCi/g) \\
\hline \hline Americium-241 & $130 \mathrm{C} 006$ & $2.490 \mathrm{E}+01$ \\
\hline Cesium-137 & $130 \mathrm{C} 006$ & $4.000 \mathrm{E}+01$ \\
\hline
\end{tabular}




\subsection{Initial Concentrations for Principal Radionuclides}

Principal radionuclides are defined as radionuclides with a half-life greater than six months. The decay products of any principal radionuclide down to, but not including, the next principal radionuclide in its decay chain are defined as associated radionuclides. The RESRAD code assumes that a principal radionuclide is in secular equilibrium with its associated radionuclides at the point of exposure. Therefore, associated radionuclides and radionuclides with half-lives less than six months are not input into the RESRAD calculations.

\subsection{Authorized Values for Initial Concentrations of Principal Radionuclides}

The authorized exposure scenarios specify that value of the arithmetic mean plus the 95 percent upper confidence limit (UCL) obtained from site-specific sampling results be entered as the principal radionuclide concentrations for RESRAD calculates. The sample results for all samples with radionuclide concentrations above the minimum detectable concentration (MDC) within the land parcels are entered into the U.S. Environmental Protection Agency (EPA) software application ProUCL version 3.0. The ProUCL software is used to calculate the 95 percent UCL for principal radionuclide concentrations based on the distribution of the unknown mean.

For instances where the ProUCL software determined that there were not enough data to calculate the 95 percent UCL for a specific radionuclide, the maximum concentration from the sample dataset was used as the initial concentration for that radionuclide.

\subsection{Authorized Values Initial Concentrations of Principal Radionuclides for Area Averaging/Location Specific Scenarios}

The DOE Order 5400.5 (DOE, 1993) states: "Residual concentrations of radioactive material in soil are defined as those in excess of background concentrations averaged over an area of $100 \mathrm{~m}^{2}$ " (5400.5, IV, 4.a.). The DOE Order 5400.5 also states: "If the average concentration of any surface or below-surface area less than or equal to $25 \mathrm{~m}^{2}$, exceeds the limit or guideline by a factor of $(100 / \mathrm{A})^{0.5}$, [where $\mathrm{A}$ is the area (in square meters) of the region in which concentrations are elevated], limits for "hot-spots" shall also be developed and applied" (5400.5, IV, 4.a.(1)). The DOE Order 5400.5, IV, 4.a.(1) indicates that criterion for these location-specific analysis is discussed in DOE G 441.1-XX, Section 5.2.2 (DOE, 2002).

The purpose of the location-specific analysis criterion is to ensure that applying the homogeneous criteria, in which the concentrations of residual radioactive material are averaged over a 100-square-meter $\left(\mathrm{m}^{2}\right)$ area, does not result in the release of small areas that, because of averaging, contain unacceptably high concentrations of residual radioactive material. The location-specific criterion is used to supplement Authorized Limits for larger areas and is intended to prevent excessive exposures from a small, contaminated area that is within a larger area that meets the basic Authorized Limits. Thus, it is intended for use in areas where the residual radioactive material concentrations are not uniform. Also, the above criterion was derived conservatively, assuming the Authorized Limits were based on a dose constraint of $25 \mathrm{mrem} / \mathrm{yr}$ and selected to ensure unlikely exposure conditions would not cause the primary dose limit (100 mrem/yr) to be exceeded. The authorized exposure scenarios specify that the 
value of the maximum concentration of principal radionuclides obtained from site-specific sampling results be entered as the principal radionuclide concentrations for RESRAD location-specific calculations. The authorized area parameters for RESRAD location-specific calculations are $1-\mathrm{m}^{2}, 10-\mathrm{m}^{2}$, and $100-\mathrm{m}^{2}$ contamination areas.

\subsection{Inhomogeneous Contamination and Initial Radionuclide Concentrations}

A contaminated zone is inhomogeneous if it contains a contaminated region within which the concentration of a radionuclide exceeds three times the average for the contaminated zone. The RESRAD code uses a mathematical construct that assumes uniform distribution of radionuclides within a volume. However, RESRAD recognizes that radiological contamination is inhomogeneous in nature and provides detailed guidance for applying inhomogeneous criteria (e.g., location-specific criteria, sum of fractions rule). The RESRAD User's Manual states that the inhomogeneous release criteria are generally more realistic and hence less restrictive than the homogeneous release criteria (Yu et al., 2001). This shows that the approved initial radionuclide concentration values (i.e., arithmetic mean plus 95 percent UCL or the maximum radionuclide concentration from the sample dataset) will result in more restrictive release criteria. The arithmetic mean plus the 95 percent UCL are used for the initial concentrations of principal radionuclides when the sample results are obtained using a random sampling method. The maximum radionuclide concentration values are used for the initial concentrations of principal radionuclides when the sample results are obtained using a non-random (e.g., bias or judgmental sampling) sampling method.

The RESRAD code states that a statistical approach should always be considered as a first priority regarding the estimation of soil concentrations, as cited in the Data Collection Handbook to Support Modeling Impacts of Radioactive Material in Soil (Yu et al., 1993). The 95 percent UCL represents a value that has a 5 percent chance that the actual mean of the dataset would exceed it. The 95 percent UCL is computed using the EPA code ProUCL. The code calculates the 95 percent UCL based on the distribution of the dataset (e.g., normal, lognormal, gamma, non-parametric).

The ProUCL software has been developed to compute an appropriate 95 percent UCL of the unknown population mean to support exposure assessment and cleanup decisions for EPA projects. A 95 percent UCL of the unknown population arithmetic mean is often used to:

- Estimate the exposure point concentration (EPC) term,

- Determine the attainment of cleanup standards,

- Estimate background level mean contaminant concentrations, or

- Compare the soil concentrations with site-specific soil screening levels.

It is important to compute a reliable, conservative, and stable 95 percent UCL of the population mean using the available data. The 95 percent UCL should approximately provide the 95 percent coverage for the unknown population mean.

The EPA has recommended that the maximum value of the dataset be used for the initial EPC term when the 95 percent UCL exceeds the maximum (EPA, 1992). However, if the maximum value of the dataset is used, then most of the statistical data associated with the distribution of the 
dataset are ignored (except for the maximum). Therefore, by using the mean plus the 95 percent UCL, the statistical data associated with the dataset are retained, and the value approaches or exceeds the maximum value of the dataset as recommended by EPA.

\subsection{Initial Concentrations of Principal Radionuclide for CAU 130, CAS 10-02-01}

The initial radionuclide concentrations used for the RESRAD calculations are those listed in Table 2-1. Because the sampling plan was biased sampling, the maximum value of the radionuclide found in the samples is used for RESRAD analysis. 


\subsection{Authorized RESRAD Exposure Pathways and Scenarios}

This section describes the input parameters, exposures scenarios, and guidance for calculating site-specific radiological remediation levels for projects using the RESRAD computer code, as agreed to by NNSA/NSO, Stoller-Navarro Joint Venture (SNJV), the NTS Management and Operating (M\&O) Contractor, and the Nevada Division of Environmental Protection (NDEP).

\subsection{Guidance for RESRAD Calculations}

The guidance in this section was developed by NNSA/NSO, SNJV, the M\&O Contractor, and NDEP and is only applicable to soils containing residual radioactive material. This guidance does not apply to structures, facilities, equipment, and building materials containing contaminated surfaces or volume contamination. The primary dose limit for any member of the public is 100-millirem (mrem) total effective dose equivalent (TEDE) in a year. This limit applies to the sum of internal and external doses resulting from all modes of exposure to all radiation sources other than background radiation and doses received as a patient from medical sources as required by DOE 5400.5, II.1.a.(3)(a) (DOE, 1993). The dose constraint is defined as one quarter of the dose limit (i.e., $25 \mathrm{mrem}$ ) and will be applied to ensure that in a 1,000-year period, the maximally exposed individual does not exceed the dose constraint in any single year. The requirements of Chapter IV of DOE 5400.5 Chapter IV will not specifically apply if NNSA/NSO chooses to continue to own and actively control access or use of the site. However, the radiation protection requirements in the other sections of DOE 5400.5 will apply to NNSA/NSO-owned and -maintained sites.

Due to the large spatial variability in background amongst sites, the "above background criterion" will be defined as the concentration of a specific radionuclide in soil that equals or exceeds its corresponding preliminary action level (PAL). The source data for these radionuclide-specific PALs are taken directly from National Council on Radiation Protection and Measurements Report No. 129, Table 2.1, Construction, Commercial, Industrial land-use scenario column for a 25-mrem dose constraint (NCRP, 1999). The generic guidelines for residual concentrations of radium ( $\mathrm{Ra}$-226, $\mathrm{Ra}-228$, thorium (Th)-230, and Th-232 are found in Chapter IV of DOE Order 5400.5, Change 2, Radiation Protection of the Public and Environment (DOE, 1993).

Background radiation refers to the local area and includes:

- Concentration of naturally occurring radionuclides.

- Cosmic radiation.

- Radionuclides of anthropogenic origin that have been globally dispersed and are present at low concentrations such as fallout from nuclear weapons. (Note: This is not the case at the NTS because the historical aspects of the NTS [e.g., atmospheric and underground testing, and other operations] resulted in dispersion of radionuclides locally.)

Due to the impracticality of determining "true" background, a dose constraint with no background subtraction will be used (i.e., a dose constraint not in excess of background). 
The use of the dose constraint with no background subtraction is a far more conservative and sensitive approach because it does not deal with the uncertainty of natural background.

\subsection{Description of Approved Scenarios}

Detailed description for each scenario can be found in the Industrial Sites Project Establishment of Final Action Levels (NNSA/NSO, 2006).

\subsection{Residual Radioactive Material Guideline}

The residual radioactive material guideline represents the concentration of residual radioactive material that can remain in place and still allow use of that area without radiological restrictions. Using site-specific parameters and sample analysis results, the radioactive material guideline, $\mathrm{G}$, can be calculated for a given dose limit of $\mathrm{H}_{\mathrm{EL}}$ for an individual as follows:

\section{$\mathrm{G}=\mathrm{HEL} / \mathrm{DSR}$}

where DSR is the total dose/source concentration ratio. The dose limit $\mathrm{H}_{\mathrm{EL}}$, used to derive the residual radioactive material guideline, is $25 \mathrm{mrem} / \mathrm{yr}$.

Single radionuclide guidelines are calculated for individual radionuclides such that the annual dose to industrial/construction workers at the site should not exceed an annual dose limitation of $25 \mathrm{mrem} / \mathrm{yr}$. Sites contaminated with two or more radionuclides (i.e., a mixture of radionuclides) require further evaluation to ensure that collective exposures from individual radionuclides do not exceed the $25-\mathrm{mrem} / \mathrm{yr}$ annual dose constraint. This evaluation is performed using a sum of the fractions method. The initial soil concentration of each radionuclide is divided by the single radionuclide guideline for that radionuclide to produce a ratio. These ratios are then summed. If the sum is less than or equal to unity, then the collective annual dose from all radionuclides at the site should not exceed the 25-mrem/yr annual dose constraint. If the sum does exceed unity, the annual dose to industrial/construction workers could exceed the 25-mrem/yr dose constraint, even if the concentrations of residual radionuclides at the site are below the single radionuclide guideline values. For sites where the sum of the ratios exceeds unity, residual radioactive material guidelines for mixtures of radionuclides are calculated such that the following equation is satisfied:

$$
\overline{\mathrm{M}}=\sum_{\mathrm{i}} \overline{\mathrm{S}}_{\mathrm{i}}\left(\mathrm{t}_{\mathrm{o}}\right) / \mathrm{G}_{\mathrm{i}}\left(\mathrm{t}_{\mathrm{m}}\right) \leq 1
$$

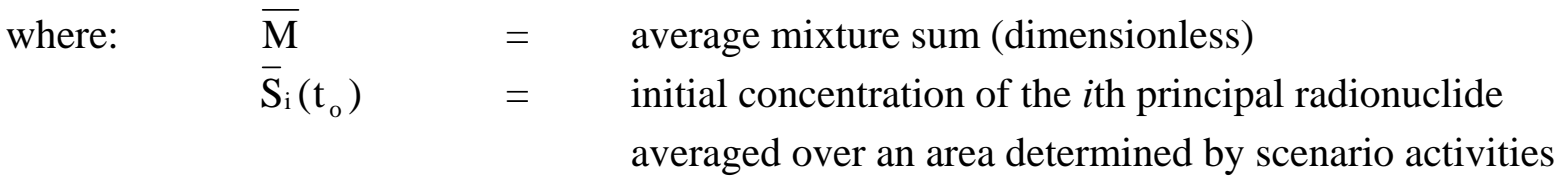




$$
\mathrm{G}_{\mathrm{i}}\left(\mathrm{t}_{\mathrm{m}}\right)=\begin{aligned}
& \text { single radionuclide soil concentration guideline for the } i \text { th } \\
& \text { principal radionuclide at time } \mathrm{t} \text { maximum }
\end{aligned}
$$

For a site where the sum of the ratios does not exceed unity, the residual radioactive guidelines for single radionuclides are the radionuclide concentrations to be used as the FAL. For sites where the sum of the ratios exceeds unity, the residual radioactive guidelines for mixtures of radionuclides are mathematically adjusted so that the above equation is satisfied. Those adjusted values are then used as the FAL. 


\subsection{RESRAD Calculations for CAU 130, CAS 10-02-01, Storage Tanks}

This section discusses the RESRAD calculations and results for CAU 130, CAS 10-02-01. Industrial Worker scenario is selected as the exposure scenario because of the operational history of the CAS and to demonstrate conservatism for the FALs.

\subsection{User Input Parameters}

The RESRAD default parameters that were modified for the calculations performed for CAU 130, CAS 10-02-01, in this report and the site-specific values entered are presented in Table 5-1. The initial radionuclide concentrations used for analyses are those listed in Table 2-1.

\subsection{Radionuclide Concentrations and Dose Estimates}

The maximum dose results from RESRAD calculations for CAU 130, CAS 10-02-01, is $12.16 \mathrm{mrem} / \mathrm{yr}$ occurring at year zero (current year). The detailed RESRAD results for this CAS are provided in Exhibit 1, RESRAD Summary Report: CAU 130, CAS 10-02-01.

Uncertainty in the derivation of dose estimates and dose/source contribution ratios comes from the distribution of possible input parameter values, as well as uncertainty in the conceptual model used to represent the site. The resulted doses from the RESRAD run are listed in Table 5-2. The pathways contributing to the total annual dose at the time of maximum dose occurs are external exposure (89.51 percent), inhalation (3.47 percent), and soil ingestion (7.02 percent). Therefore, uncertainties in the following parameters - soil disturbance (e.g., erosion rates), thickness of contaminated zone, and occupancy factors - have the greatest significance on the model predictions.

Because the radionuclide concentrations found at this site pose a dose level below the 25-mrem/yr constraint under the current site conditions, remediation alternative is not necessary for the site.

\subsection{Residual Radioactive Material Guidelines for CAU 130, CAS 10-02-01}

The sum of the ratios for CAU 130, CAS 10-02-01, does not exceed unity. Table 5-3 presents the calculations results for deriving guidelines for radionuclides for this CAS. The FAL for the CAU 130, CAS 10-02-01, scenario is the residual radioactive material guideline values for single radionuclide. 


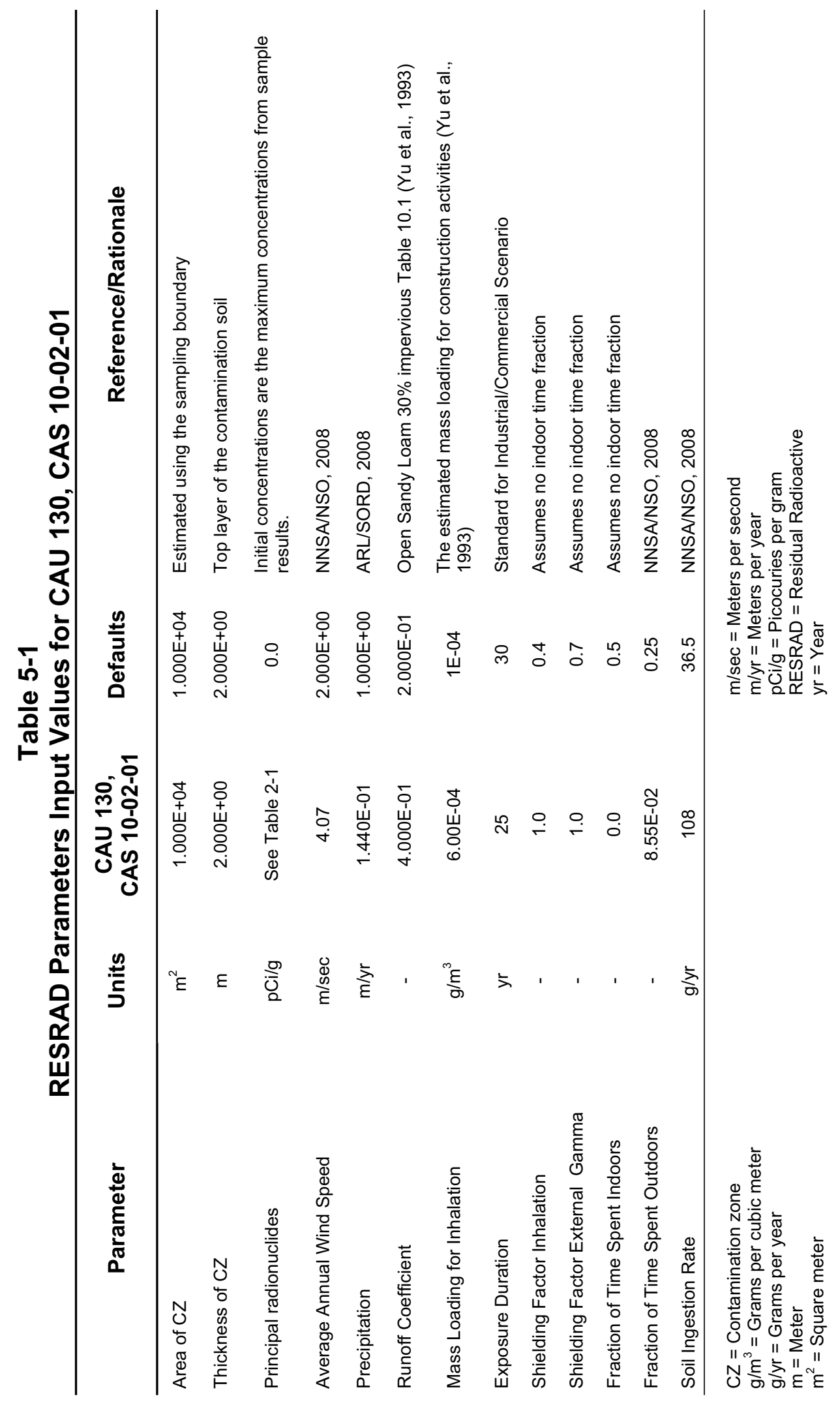



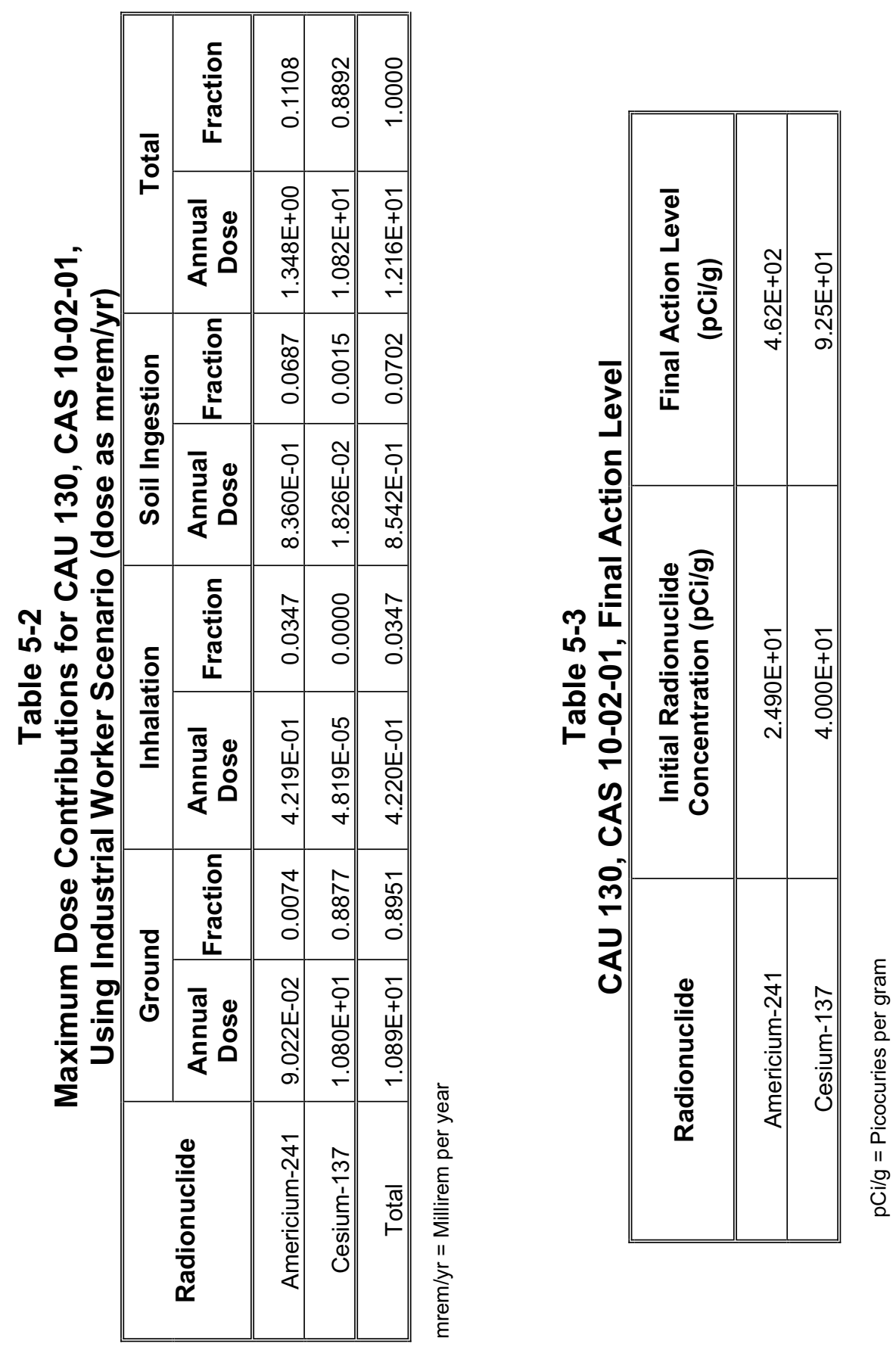


\subsection{References}

ARL/SORD, see Air Resources Laboratory/Special Operations and Research Division.

Air Resources Laboratory/Special Operations and Research Division. 2008. "Climatological Information and Data." As accessed at http://www.sord.nv.doe.gov on 23 November.

DOE, see U.S. Department of Energy.

EPA, see U.S. Environmental Protection Agency.

NCRP, see National Council on Radiation Protection and Measurements.

NNSA/NSO, see U.S. Department of Energy, National Nuclear Security Administration Nevada Site Office.

National Council on Radiation Protection and Measurements. 1999. Recommended Screening Limits for Contaminated Surface Soil and Review of Factors Relevant to Site-Specific Studies, NCRP Report No. 129. Bethesda, MD.

U.S. Department of Energy. 1993. Radiation Protection of the Public and the Environment, DOE 5400.5, Change 2. Washington, DC.

U.S. Department of Energy. 2002. Draft Implementation Guide, Control and Release of Property with Residual Radioactive Material, for use with DOE 5400.5, Radiation Protection of the Public and the Environment, DOE G 441.1-XX. Washington, DC.

U.S. Department of Energy, National Nuclear Security Administration Nevada Site Office. 2006. Industrial Sites Project Establishment of Final Action Levels, Rev. 0, DOE/NV--1107. Las Vegas, NV.

U.S. Department of Energy, National Nuclear Security Administration Nevada Site Office. 2008. Streamlined Approach for Environmental Restoration (SAFER) for Corrective Action Unit 130: Storage Tanks, Nevada Test Site, Nevada, Rev. 0, DOE/NV--1276.

Las Vegas, NV.

U.S. Environmental Protection Agency. 1992. Guidance on Risk Managers and Risk Assessors. Memorandum from F.H. Habicht, Deputy Administrator. Washington, DC.

Yu, C., C. Loureiro, C.C. Cheng, L.G. Jones, Y.Y. Wang, Y.P. Chia, and E. Faillace. 1993. Data Collection Handbook To Support Modeling the Impacts of Radioactive Material in Soil, ANL/EAIS-8. Chicago, IL: Argonne National Laboratory, Environmental Assessment Division. 
Yu C., A.J. Zielen, J.J Cheng, D.J. LePoire., E. Gnanapragasam, S. Kamboj, J. Arnish, A. Wallo III, W.A. Williams, and H. Peterson. 2001. User's Manual for RESRAD Version 6, ANL/EAD-4. Argonne, IL: Argonne National Laboratory, Environmental Assessment Division. 


\section{Exhibit 1}

\section{RESRAD Summary Report: CAU 130, CAS 10-02-01}

(18 pages) 


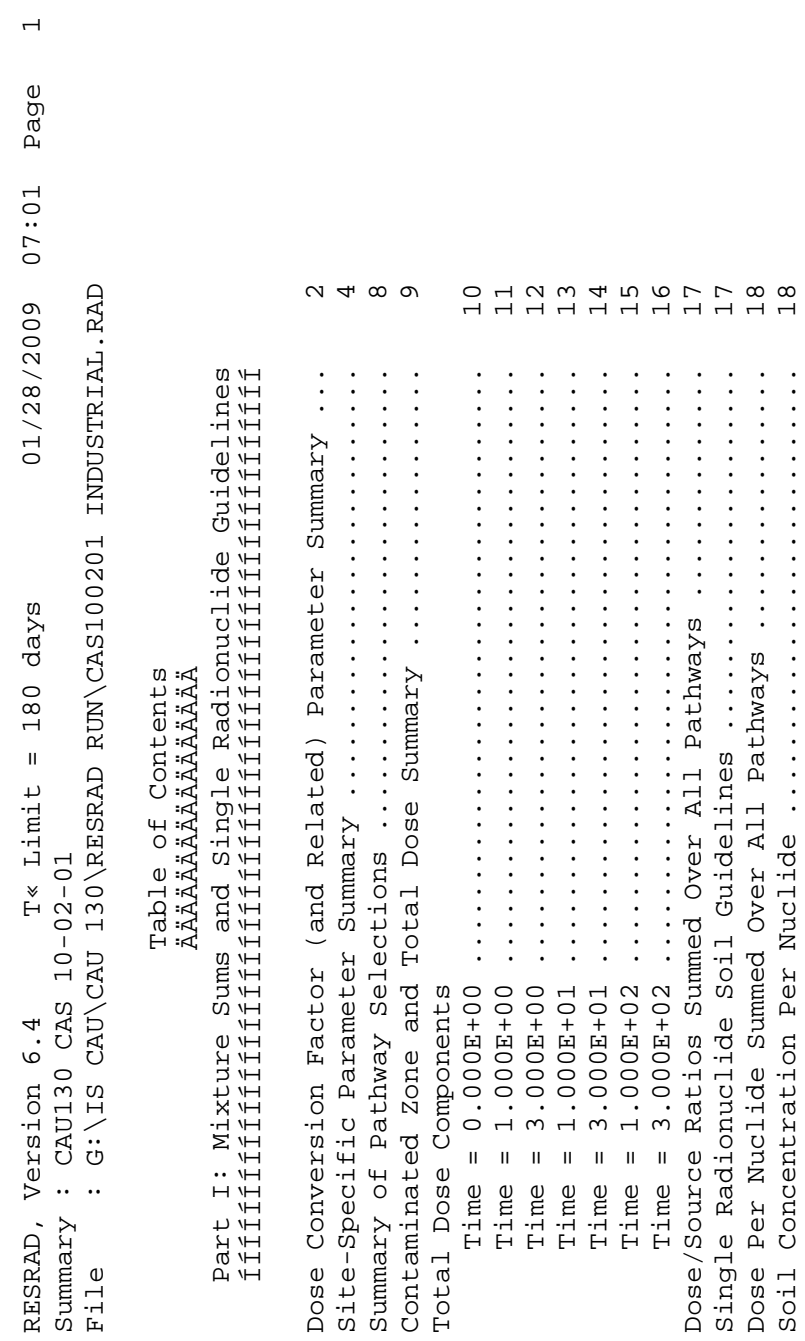




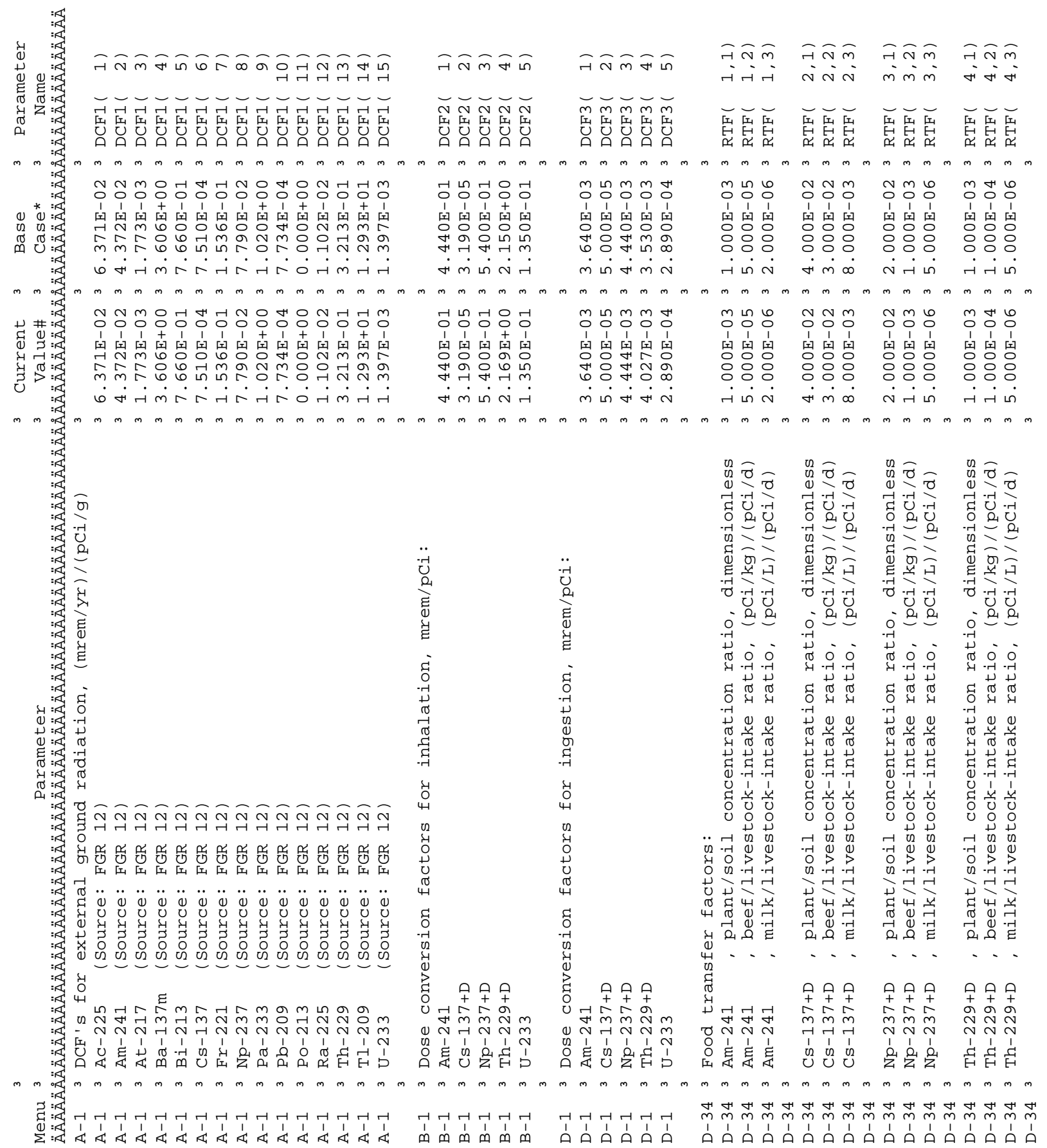




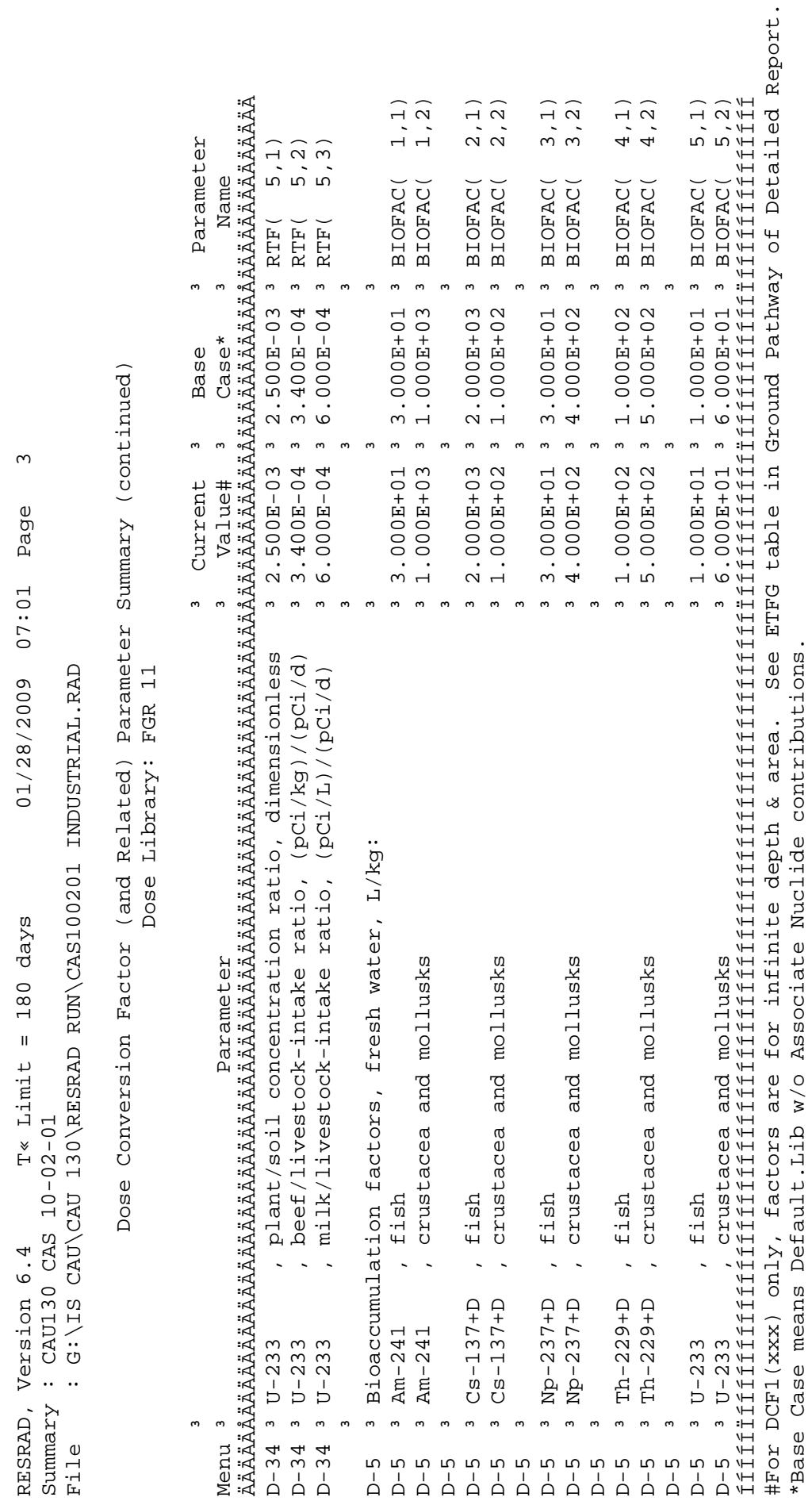

UNCONTROLLED When Printed 


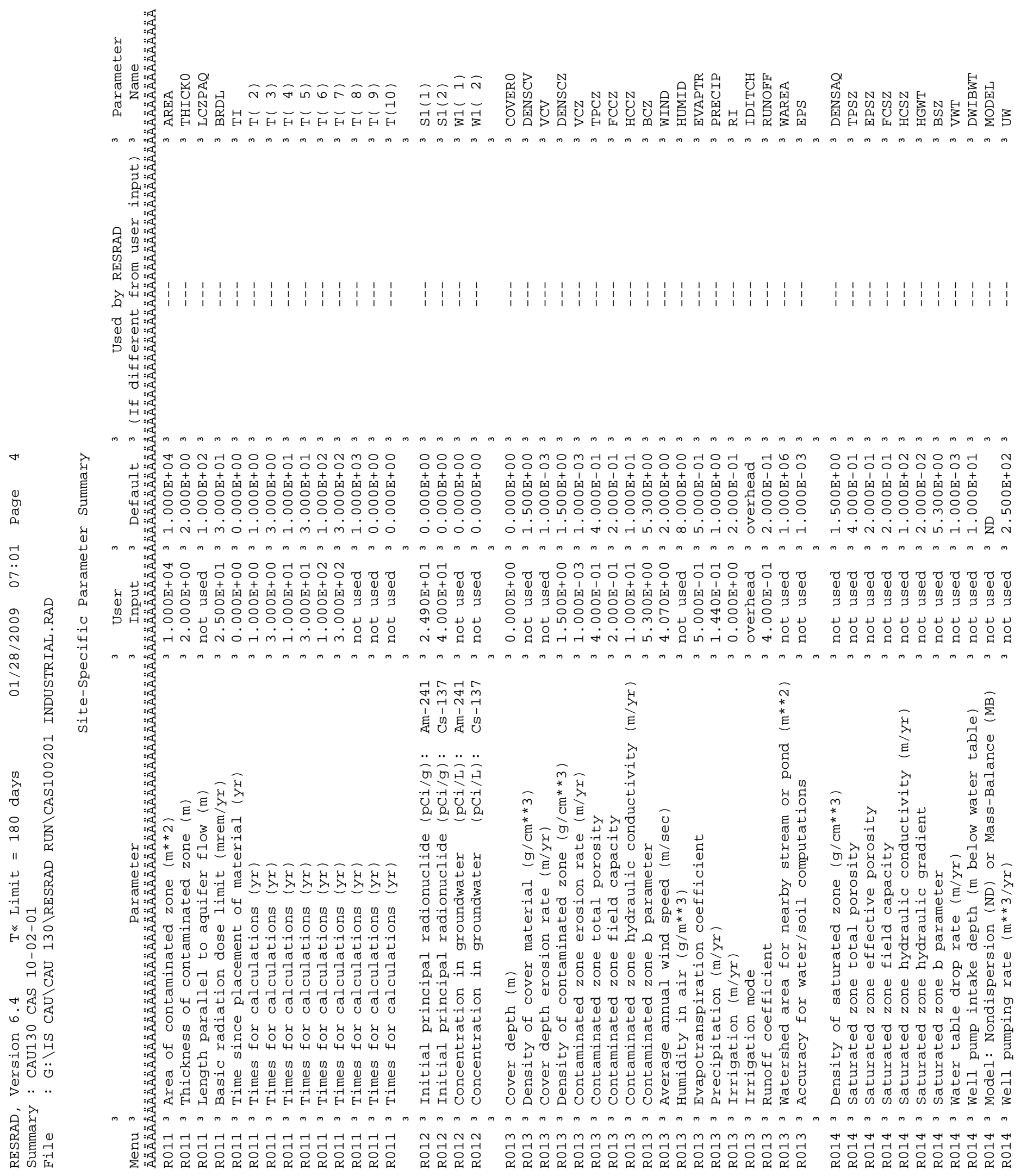




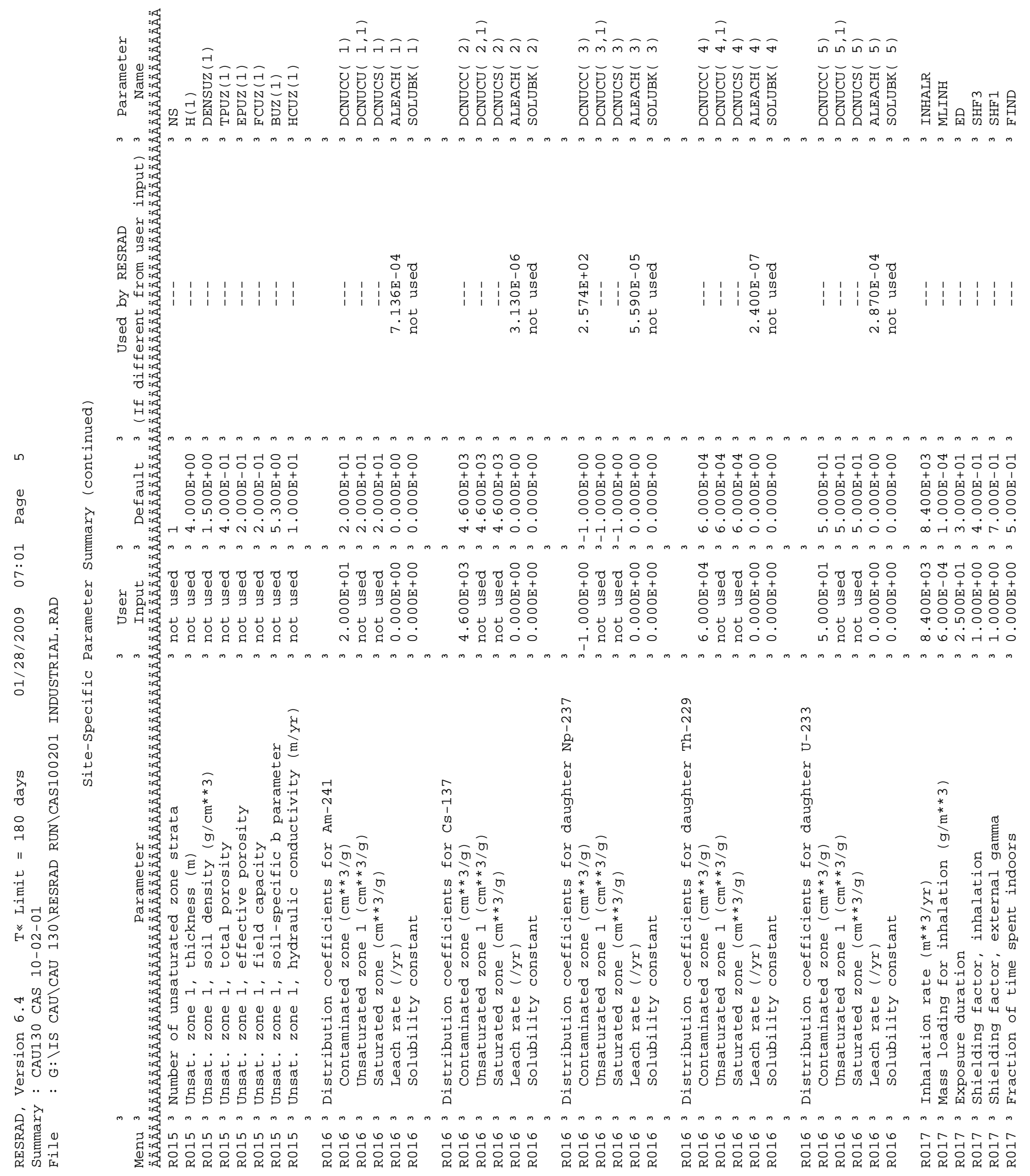




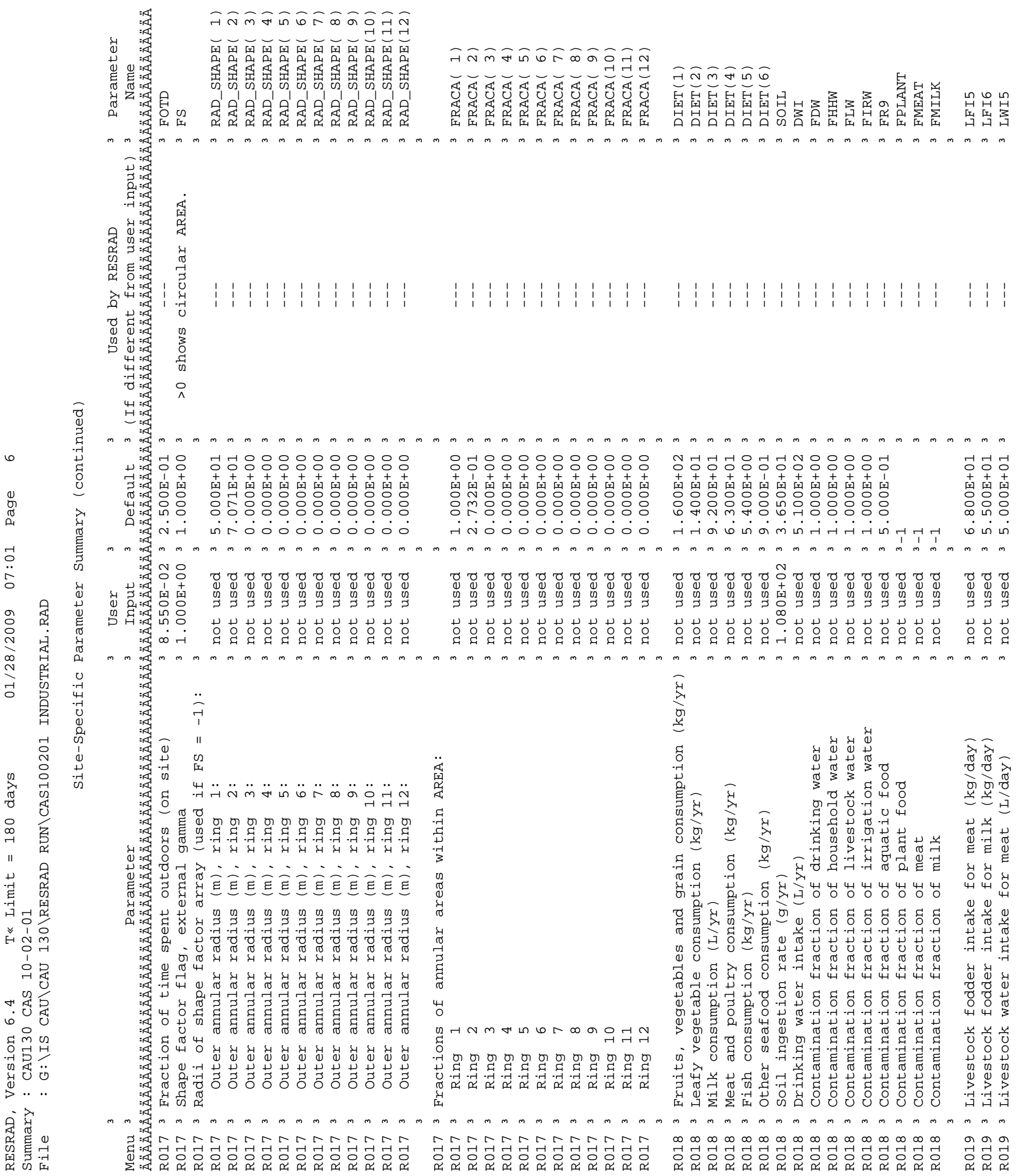




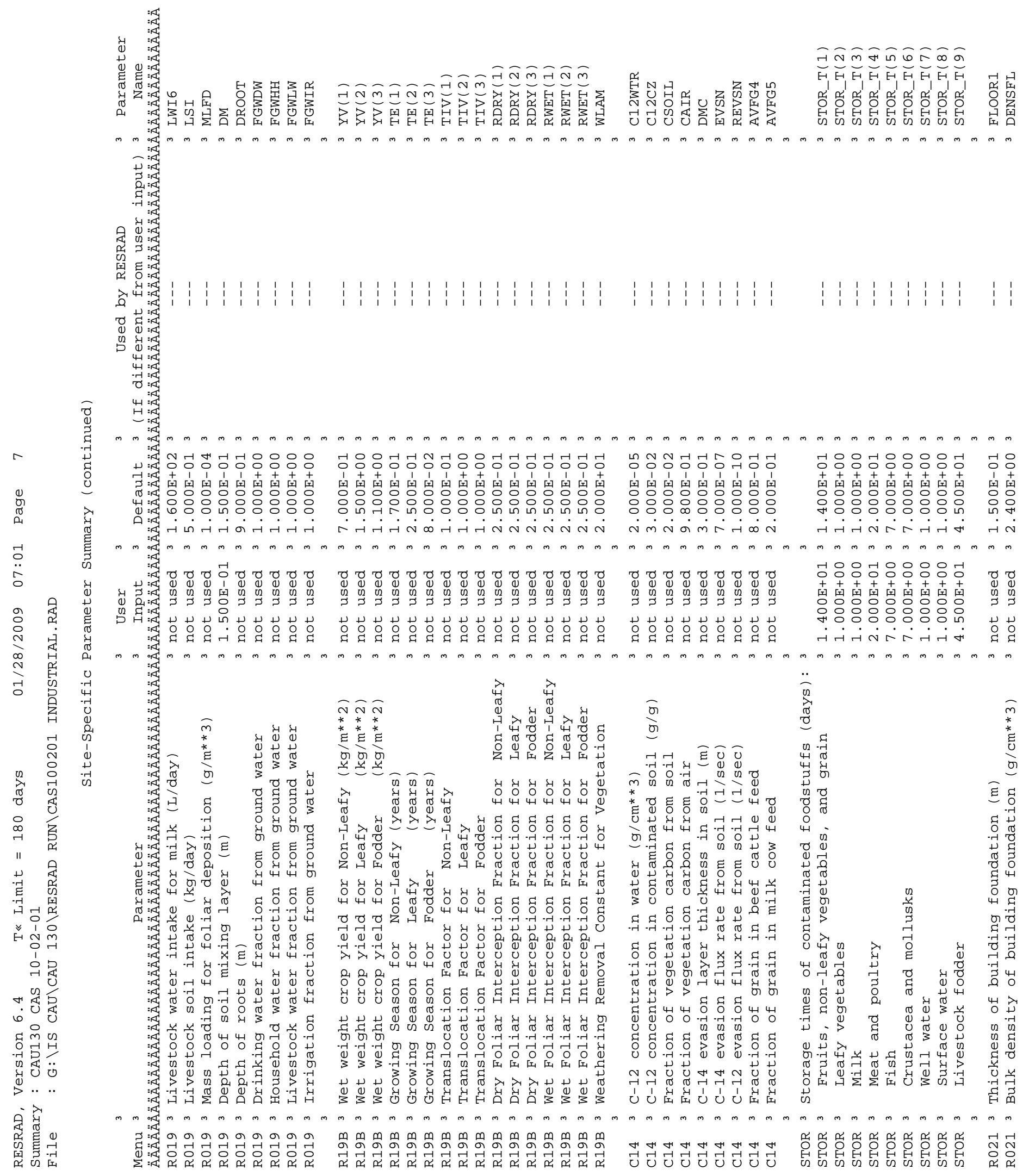



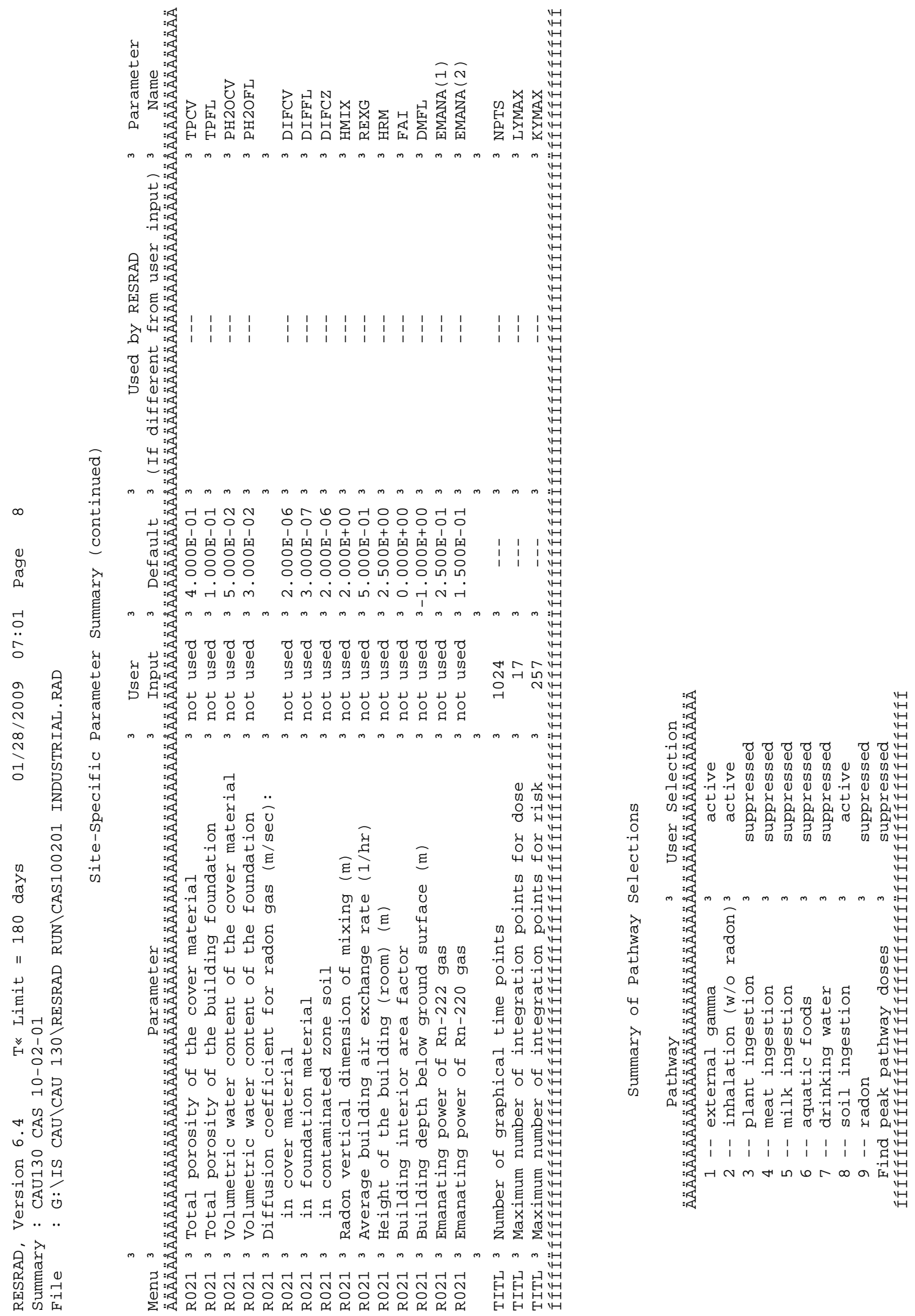


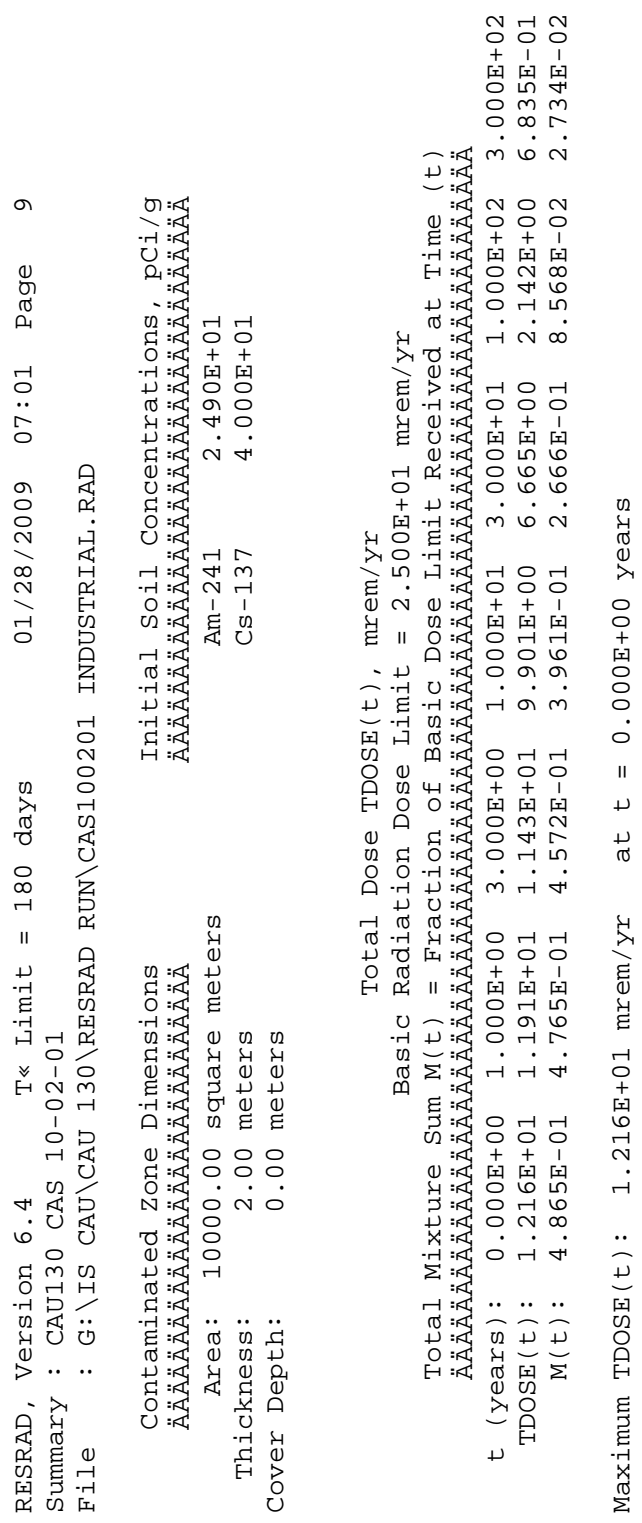

UNCONTROLLED When Printed 


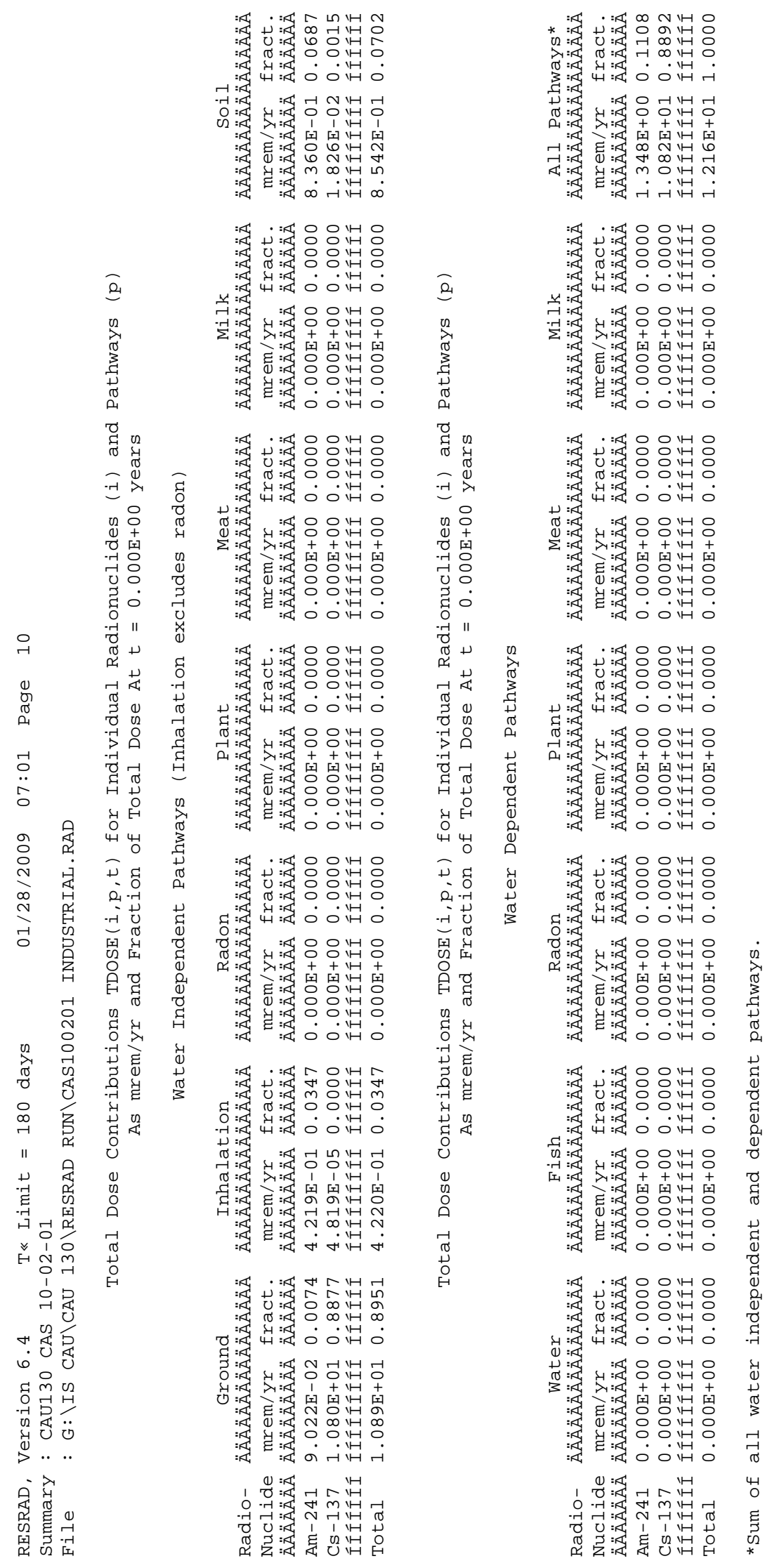



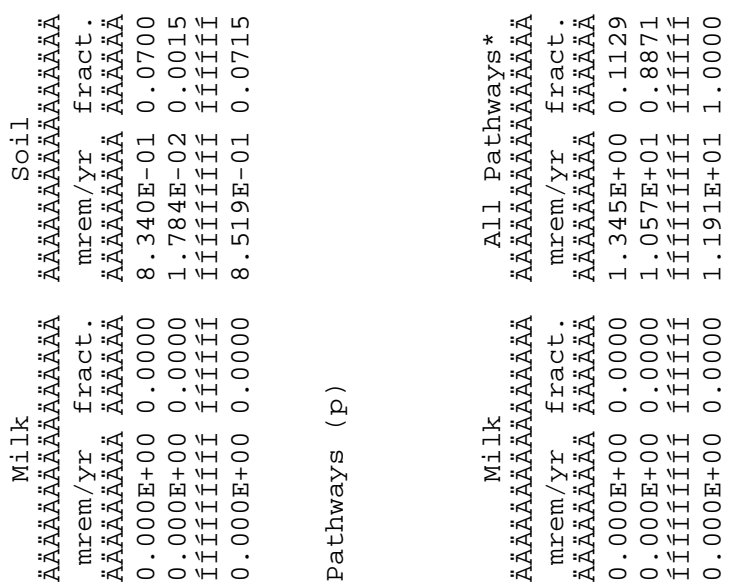

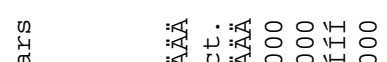

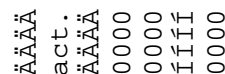

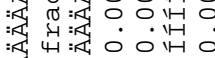
ه : : 派嵌派只只出。

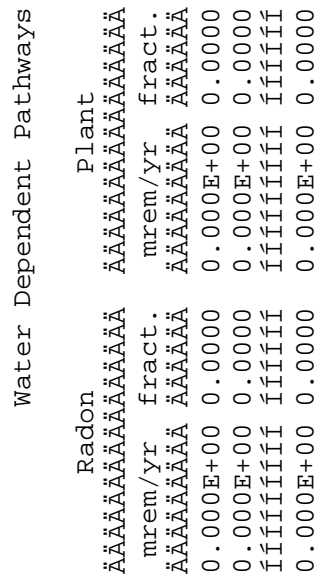

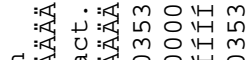

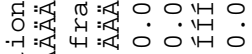

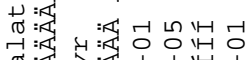

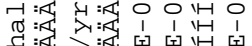

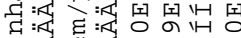
泒㟔滛

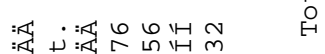

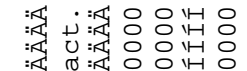

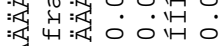

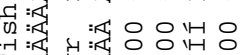
봐

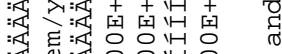
: 派派官家出。

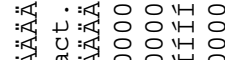
म :

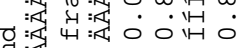
唈蛋忩

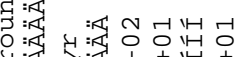
岁: 这 1 质 ह派

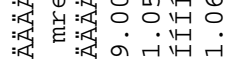

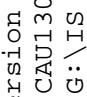
$>$... .

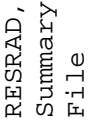

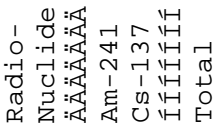
诞 质 ㄱ:41 +

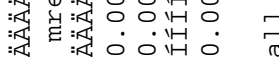

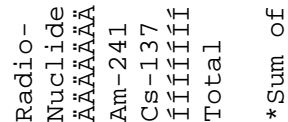




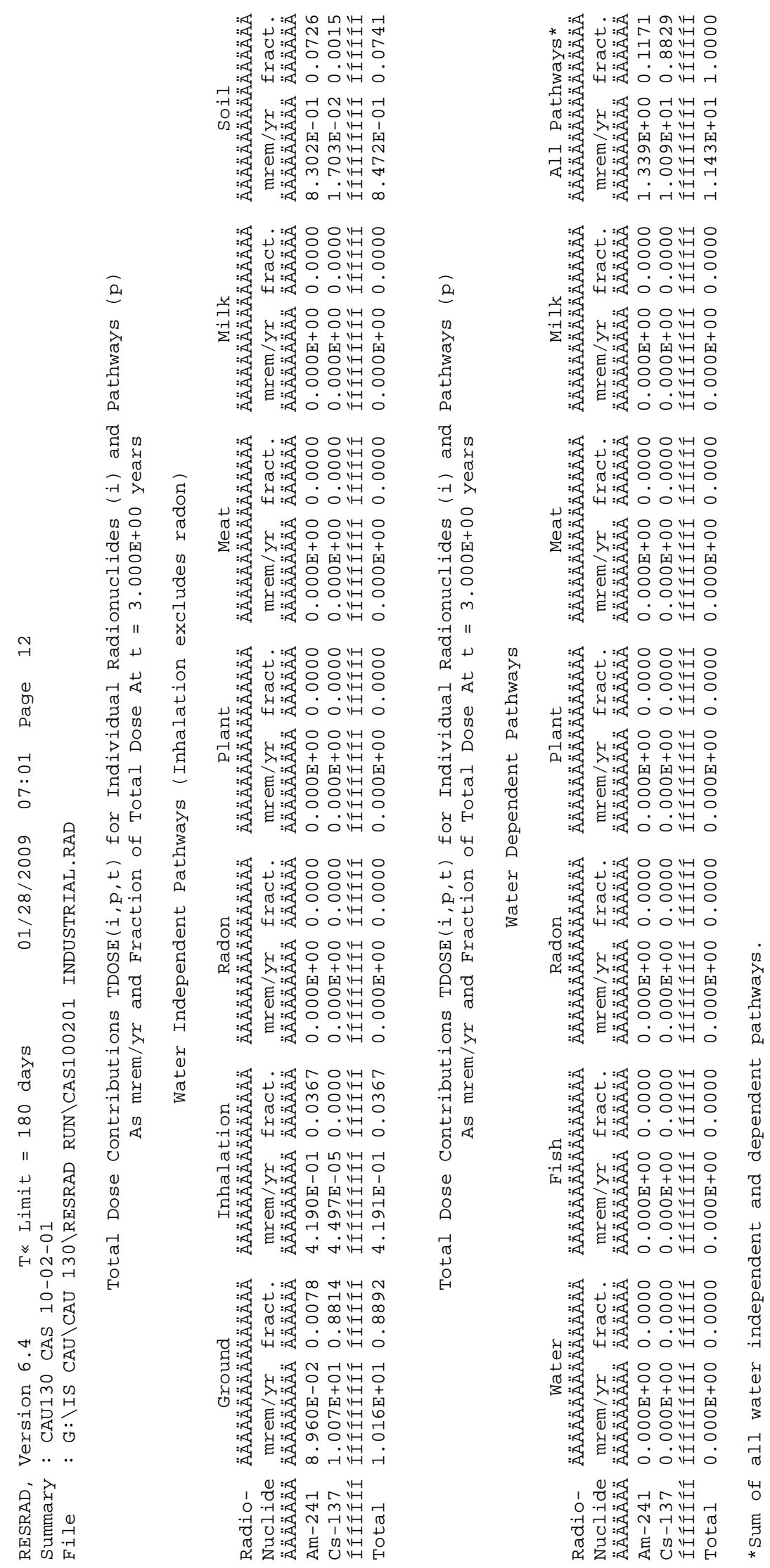

UNCONTROLLED When Printed 


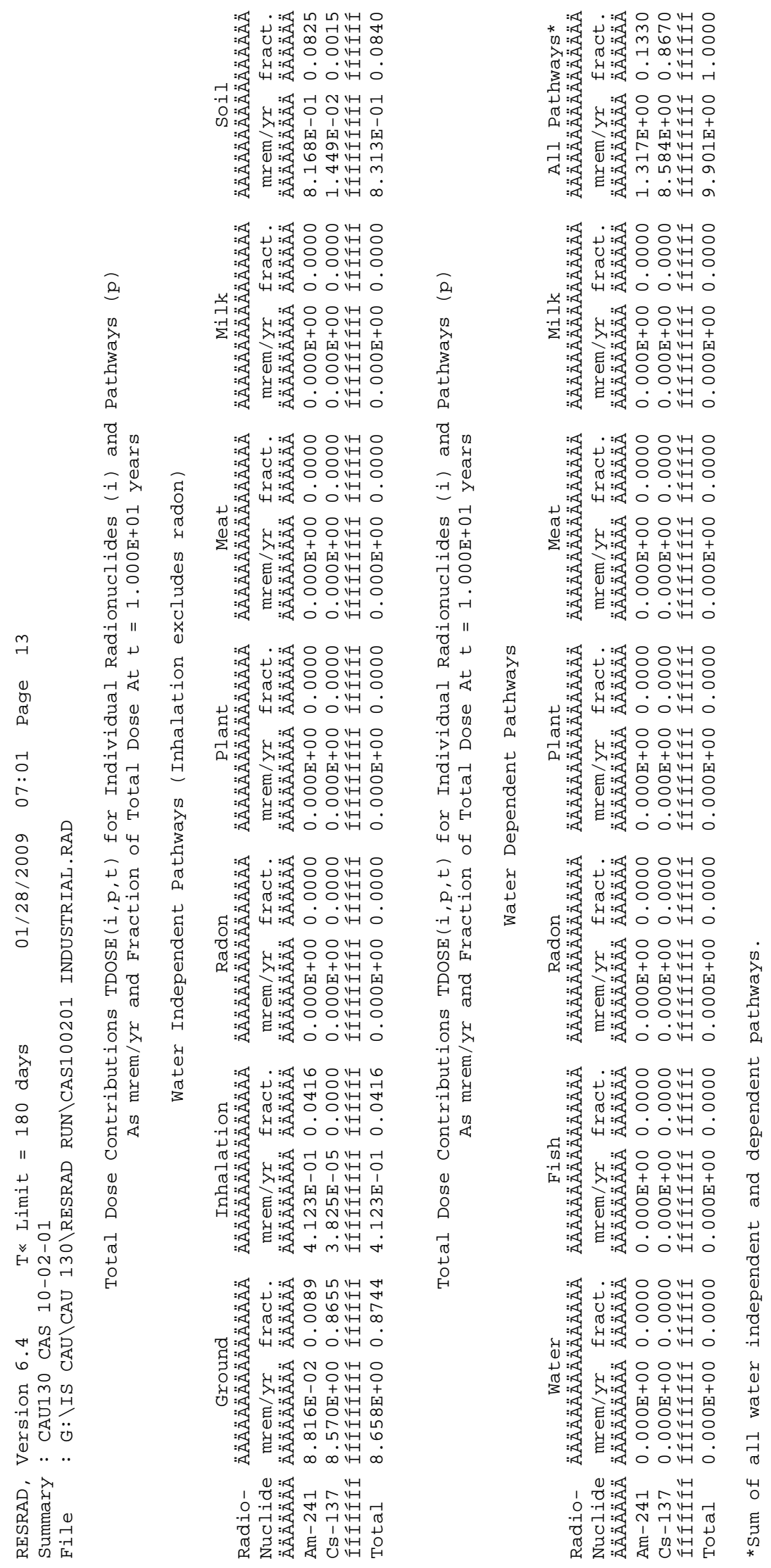




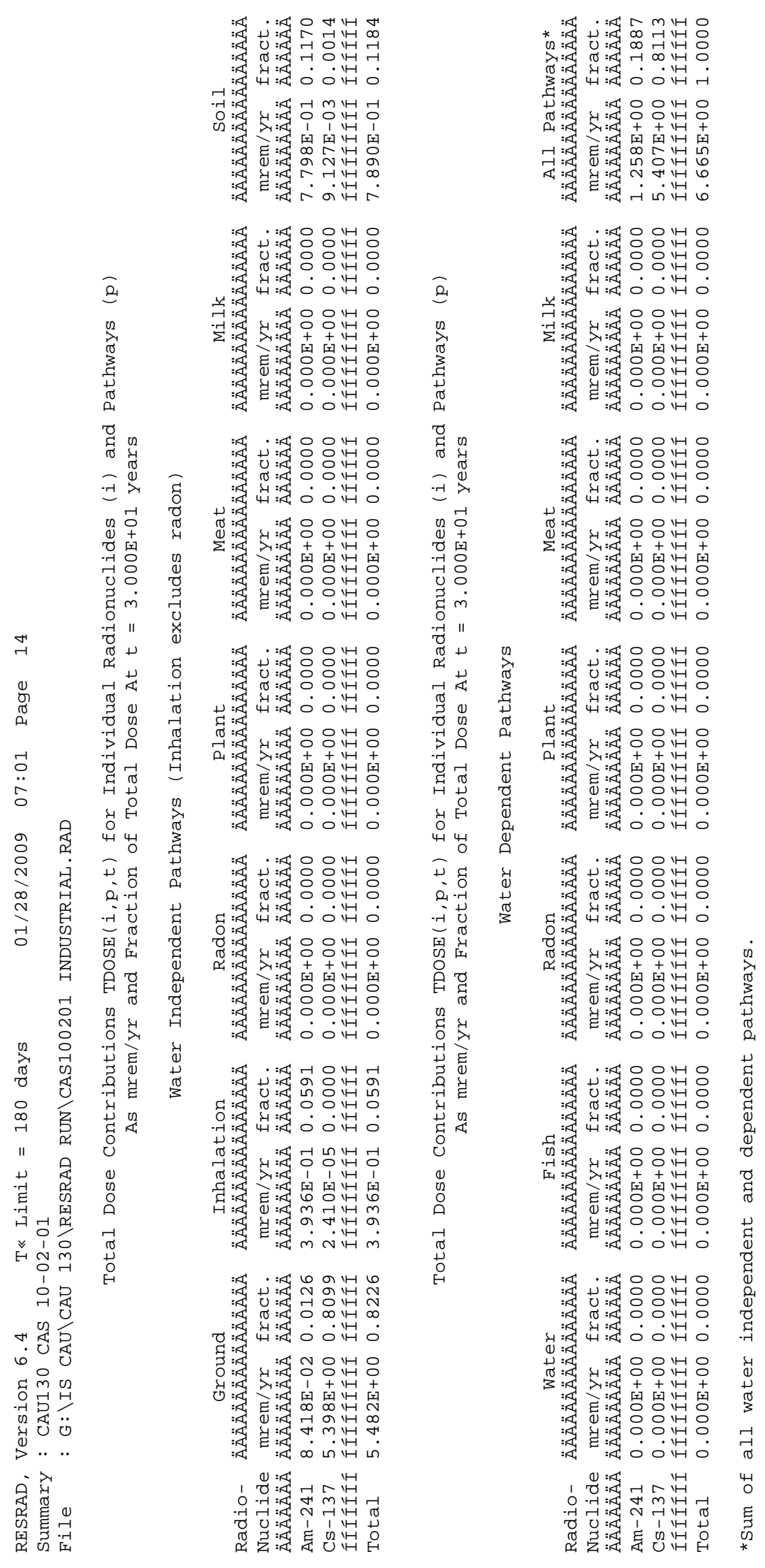




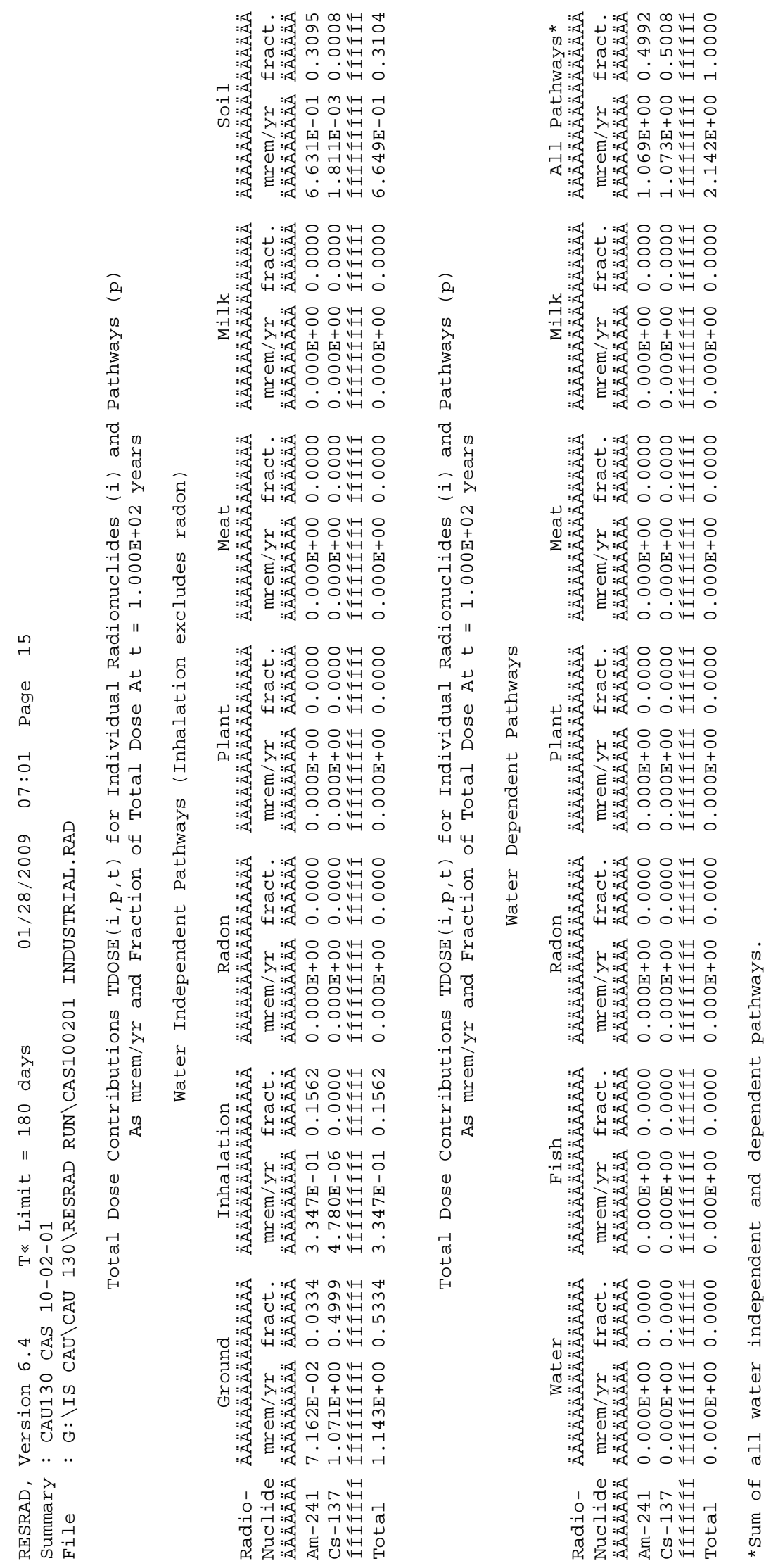

UNCONTROLLED When Printed 

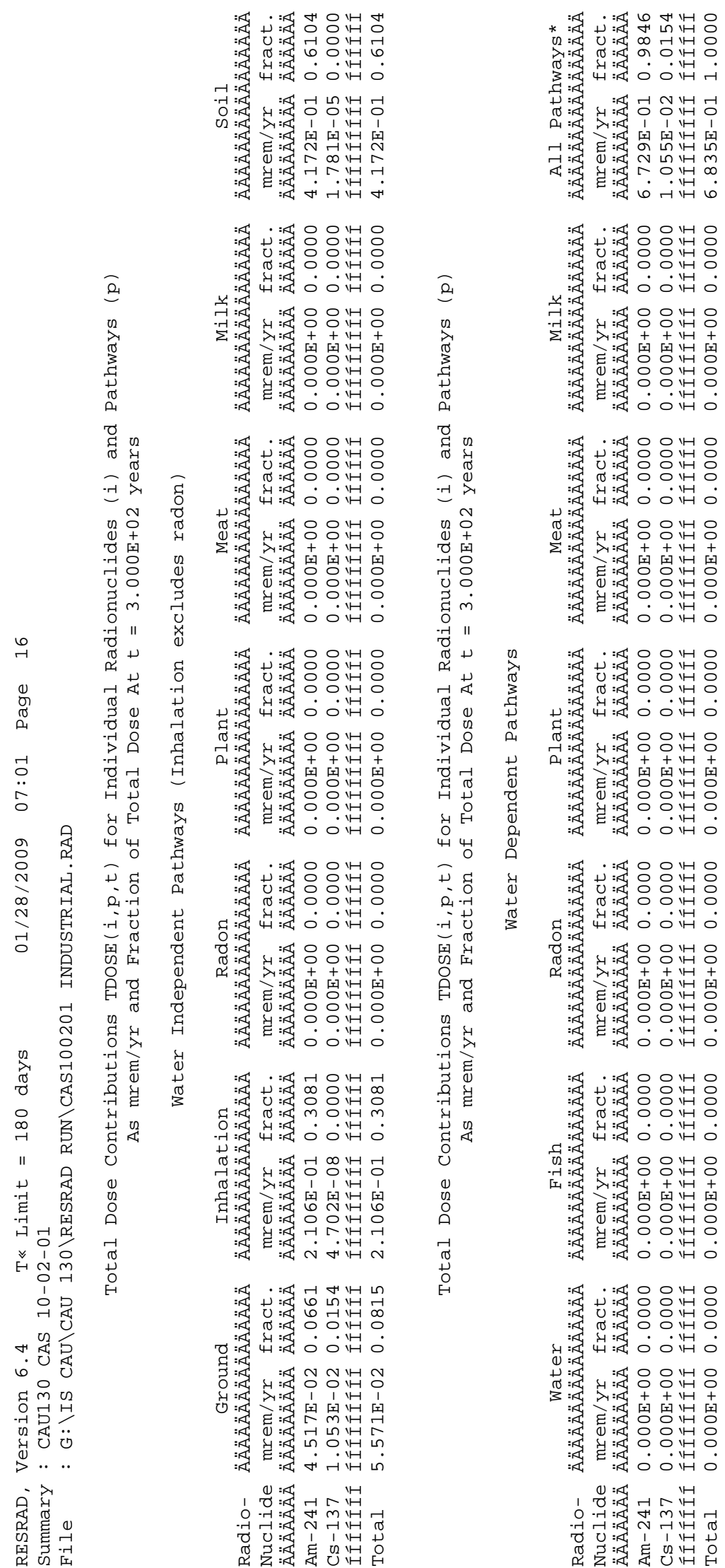

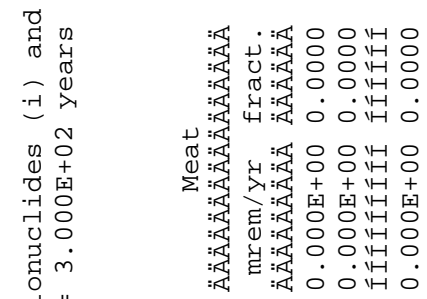

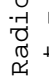

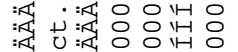

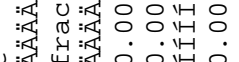

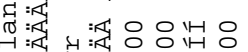

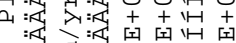

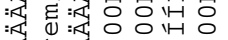

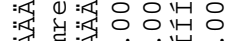

: 派

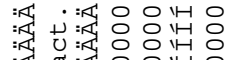

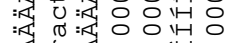

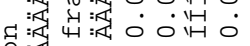

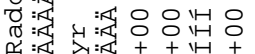

: 而

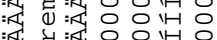

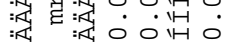

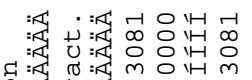

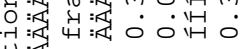

槄

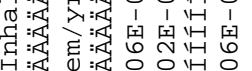

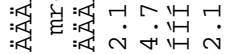

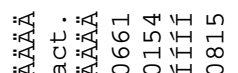

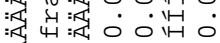

ס:

S:

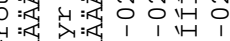

: 瓝派 되베

:

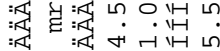

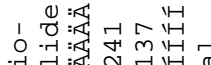

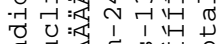

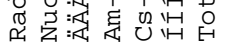

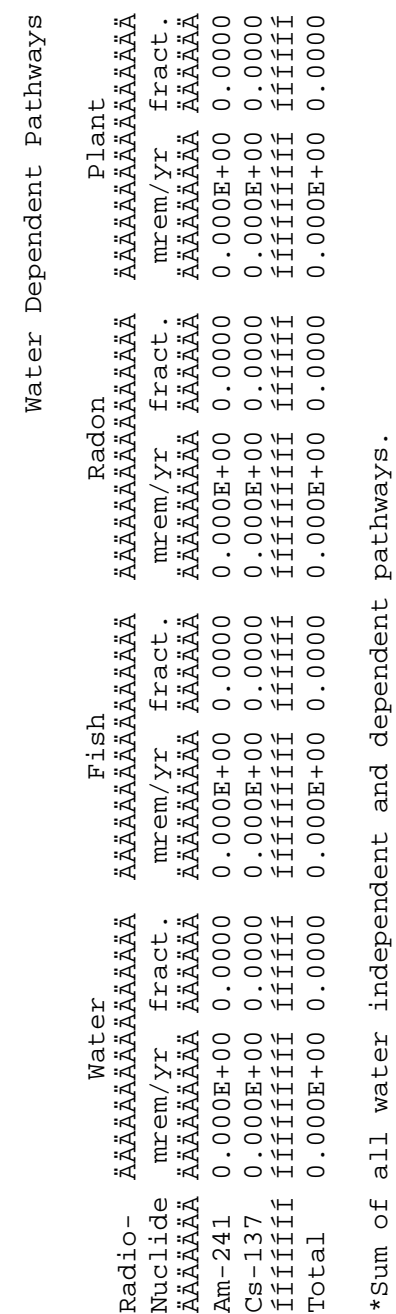

UNCONTROLLED When Printed 

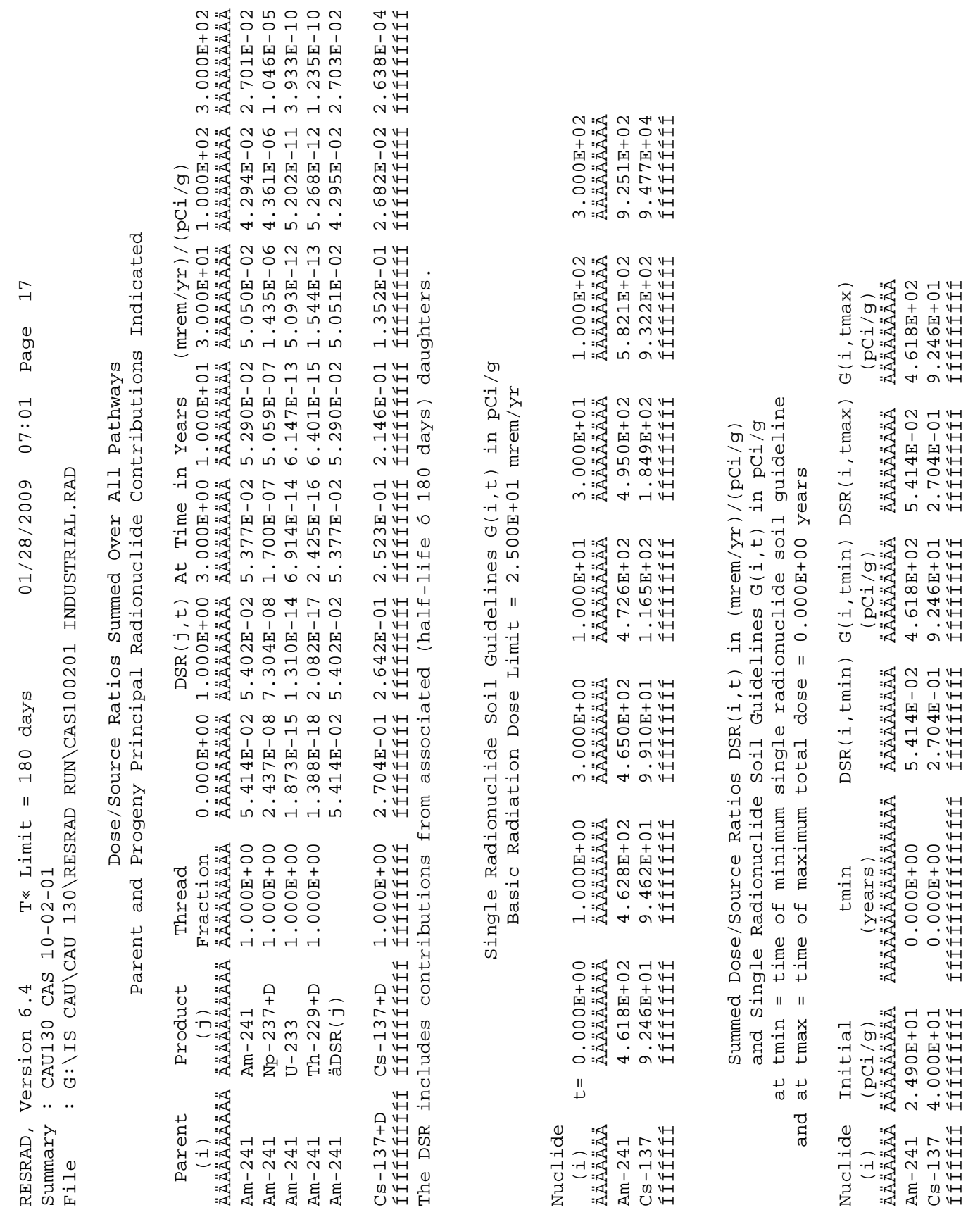


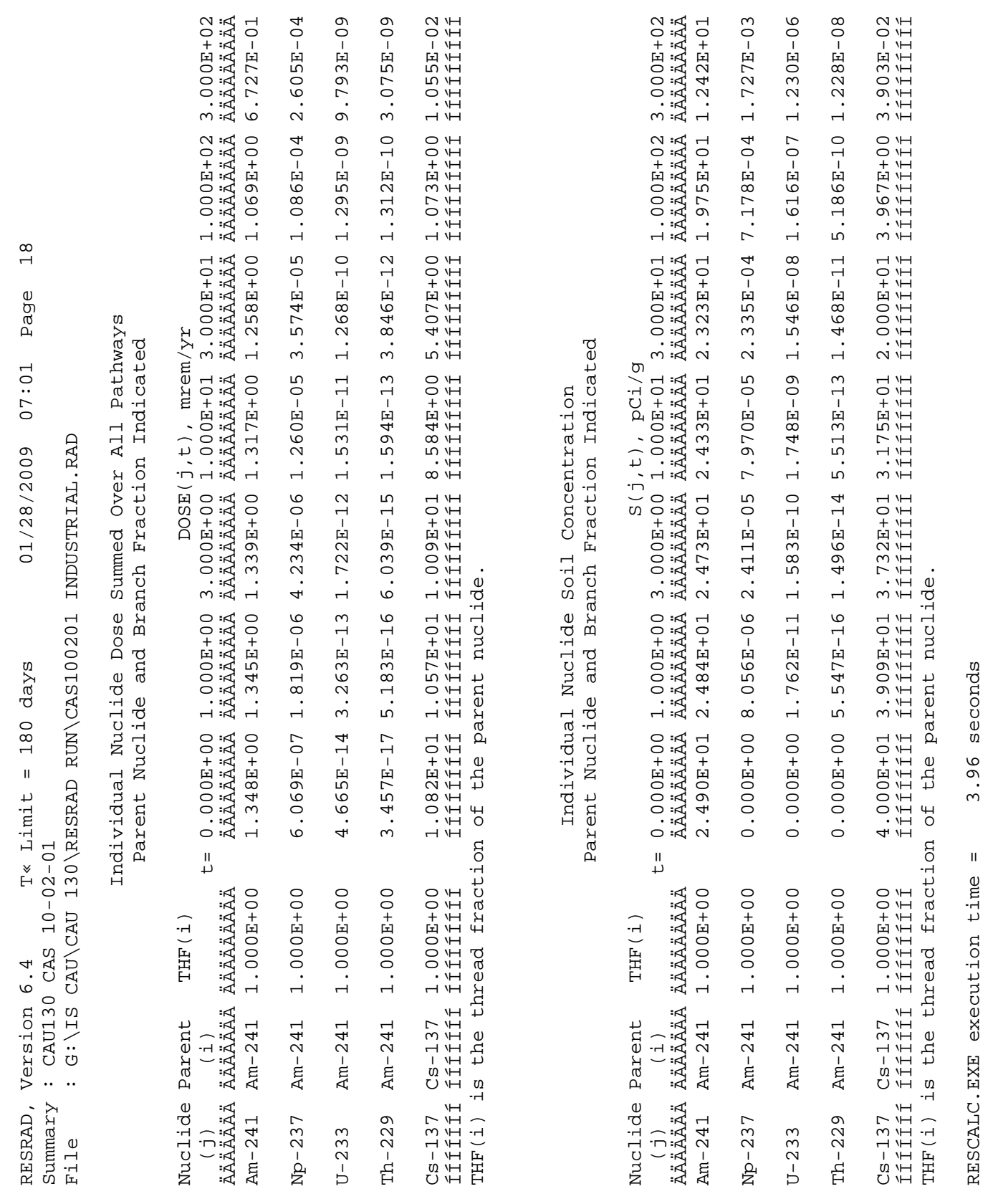

UNCONTROLLED When Printed 


\section{Appendix I \\ Nevada Division of Environmental Protection Comments \\ (3 Pages)}




\section{NEVADA ENVIRONMENTAL RESTORATION PROJECT DOCUMENT REVIEW SHEET}

\begin{tabular}{|c|c|c|}
\hline 1. Document Title/Number: & $\begin{array}{l}\text { Draft Closure Report for Corrective Action Unit 130: Storage Tanks, Nevada Test } \\
\text { Site, Nevada }\end{array}$ & 2. Document Date: $\quad 02 / 04 / 2009$ \\
\hline \multicolumn{2}{|l|}{ 3. Revision Number: 0} & 4. Originator/Organization: Stoller-Navarro \\
\hline \multicolumn{2}{|c|}{ 5. Responsible NNSA/NV ERP Project Manager: Kevin J. Cabble } & 6. Date Comments Due: 03/06/2009 \\
\hline \multicolumn{3}{|l|}{ 7. Review Criteria: Full } \\
\hline \multicolumn{2}{|c|}{ 8. Reviewer/Organization/Phone No: Dennis Nicodemus, NDEP, 486-2850 } & 9. Reviewer's Signature: \\
\hline
\end{tabular}

\begin{tabular}{|c|c|c|c|c|}
\hline $\begin{array}{l}\text { 10. Comment } \\
\text { Number/Location }\end{array}$ & 11. Type* & 12. Comment & 13. Comment Response & 14. Accept \\
\hline $\begin{array}{l}\text { 1.) Section } 4.0 \text {, } \\
\text { Page } 20\end{array}$ & Mandatory & $\begin{array}{l}\text { Paragraph } 5 \text { can be written in a manner more easily } \\
\text { understood. "Verification soil samples were collected } \\
\text { below the lead bricks and analyzed. No sample was } \\
\text { detected above the PALs and no additional COCs } \\
\text { were identified at this CAS. The CAS was determined } \\
\text { to be a clean closure and the analytical data supports } \\
\text { NFA." } \\
\text { Paragraph } 6 \text { should be rewritten to specify that diesel } \\
\text { range organics were the cause of the TPH exceeding } \\
\text { the preliminary PALs in the first sentence. }\end{array}$ & $\begin{array}{l}\text { Section } 4.0 \text {, Page } 20 \text {, Paragraph } 5 \text {, has been rewritten } \\
\text { for clarification. "Although no COCs were identified at } \\
\text { CAS } 07-02-01 \text {, PSM in the form of lead bricks was } \\
\text { present. These bricks were removed as a corrective } \\
\text { action of clean closure and beneficially recycled within } \\
\text { the DOE Complex reclycling program. Verification soil } \\
\text { samples were collected below the lead bricks and } \\
\text { analyzed. The analytical data verify the successful } \\
\text { completion of clean closure." } \\
\text { Paragraph } 6,1 \text { st sentence has been changed to read } \\
\text { "Total petroleum hydrocarbons-diesel-range organics, } \\
\text { were detected above the preliminary action level } \\
\text { (PAL)...". }\end{array}$ & \\
\hline $\begin{array}{l}\text { 2.) Section } \\
\text { 4.1.1.1.1 Criterion } \\
2 \text {, Page } 23\end{array}$ & Mandatory & $\begin{array}{l}\text { Specify the CAS for the analytes that failed sensitivity } \\
\text { in this paragraph. }\end{array}$ & $\begin{array}{l}\text { Section } 4.1 .1 .1 .1 \text { Criterion } 2, \text { Page } 23, \text { CAS } 23-02-07 \\
\text { was added to identify the CAS for the analytes that } \\
\text { failed sensitivity. }\end{array}$ & \\
\hline
\end{tabular}


NEVADA ENVIRONMENTAL RESTORATION PROJECT

DOCUMENT REVIEW SHEET

\begin{tabular}{|c|c|c|c|c|}
\hline $\begin{array}{l}\text { 10. Comment } \\
\text { Number/Location }\end{array}$ & 11. Type* & 12. Comment & 13. Comment Response & 14. Accept \\
\hline $\begin{array}{l}\text { 3.) Section } \\
4.1 .1 .1 .1 \\
\text { Completeness, } \\
\text { Page } 27\end{array}$ & Mandatory & $\begin{array}{l}\text { This section states no data were rejected. However, } \\
\text { back in the Criterion } 2 \text { section (page } 23 \text { ) some results } \\
\text { are mentioned as being rejected. Provide explanation. }\end{array}$ & $\begin{array}{l}\text { Section 4.1.1.1.1, Page 27, Completeness, Paragraph } \\
1 \text { has been revised for clarity to read: "The CAU } 130 \\
\text { SAFER Plan......and } 100 \text { percent of target } \\
\text { contaminants having valid results (including Decision II } \\
\text { samples). Also the data set must be......DQO } \\
\text { decisions. Target analytes for the CAU } 130 \\
\text { CASs ............constituents of diesel..... at CAS 22-02- } \\
\text { 02. There were no data qualified as rejected for CAU } \\
\text { 130. However, Table } 4-2 \text { lists samples from CAS 23- } \\
\text { 02-07 that were rejected for failing sensitivity." } \\
\text { In addition, a 2nd and 3rd paragraph have been added } \\
\text { for explanation that read: "Benzo(a)pyrene and } \\
\text { dibenzo(a,h,)anthracene did not meet the criteria for } \\
\text { sensitivity and are, therefore, considered rejected data } \\
\text { that did not meet the } 100 \text { percent completeness } \\
\text { criterion for targeted contaminants. The data that } \\
\text { failed sensitivity were not used in the resolution of } \\
\text { DQO decisions." } \\
\text { "The benzo(a)pyrene and dibenzo(a,h,)anthracene } \\
\text { failed sensitivity in one sample from CAS } 23-02-07 \\
\text { (130G001) because it was diluted during preparation } \\
\text { due to matrix interferences, which resulted in elevated } \\
\text { detection limits that were greater than their } \\
\text { corresponding FAL concentrations. However, valid } \\
\text { results were obtained for these two contaminants in } \\
\text { three other samples from this CAS in which these } \\
\text { contaminants were not detected. Therefore, there is } \\
\text { no suspicion that these contaminants are present at } \\
\text { CAS } 23-02-07, \text { and there is sufficient information to } \\
\text { support the DQO decisions at this CAS. Therefore, the } \\
\text { dataset was determined to be acceptable for } \\
\text { completeness." }\end{array}$ & \\
\hline $\begin{array}{l}\text { 4.) Table 4-2, Page } \\
25\end{array}$ & Mandatory & $\begin{array}{l}\text { Note the appropriate CAS from which the rejected } \\
\text { samples were taken. }\end{array}$ & $\begin{array}{l}\text { Table 4-2, Page } 25 \text {, CAS } 23-02-07 \text { has been added to } \\
\text { the Table Title. }\end{array}$ & \\
\hline
\end{tabular}


NEVADA ENVIRONMENTAL RESTORATION PROJECT

DOCUMENT REVIEW SHEET

\begin{tabular}{|c|c|c|c|c|}
\hline \\
\hline $\begin{array}{l}\text { 10. Comment } \\
\text { Number/Location }\end{array}$ & 11. Type* & 12. Comment & 13. Comment Response & 14. Accept \\
\hline $\begin{array}{l}\text { 5.) Table H.1-10, } \\
\text { Page H-16 }\end{array}$ & Mandatory & $\begin{array}{l}\text { Provide footnote referencing Table } 4-2 \text { and include } \\
\text { explanation how the ND reported value for Benzo(a) } \\
\text { Pyrene and Dibenzo(a,h)Anthracene can be made with } \\
\text { their respective PALs being below MDCs. }\end{array}$ & $\begin{array}{l}\text { A footnote has been added to Table H.1-10. Page H- } \\
16 \text { that reads: } \\
\text { "For clarification of the benzo(a)pyrene and dibenzo } \\
\text { (a,h)anthracene see Section 4.1.1.1.1 Completeness } \\
\text { and Table 4-2." }\end{array}$ & \\
\hline $\begin{array}{l}\text { 6.) Section A.4.2.2, } \\
\text { Page A-21 }\end{array}$ & Mandatory & $\begin{array}{l}\text { Table 3-4 doesn't exist and Table A.2.3 doesn't seem } \\
\text { applicable to reference in this paragraph. }\end{array}$ & $\begin{array}{l}\text { Section A.4.2.2, Page A-21, } \\
\text { This Appendix is the DQOs directly from the CAU } 130 \\
\text { Final SAFER Plan. The sentence has been clarified to } \\
\text { "....are provided in Tables } 3-4 \text { and } 3-5 \text { of the CAU } 130 \\
\text { SAFER Plan." }\end{array}$ & \\
\hline $\begin{array}{l}\text { 7.) Section D.6.1.3, } \\
\text { Page D-38 }\end{array}$ & Mandatory & $\begin{array}{l}\text { Is the aerial radiological survey listed the most recent } \\
\text { for this CAS? }\end{array}$ & $\begin{array}{l}\text { Section D.6.1.3, Page D-38, The aerial radiological } \\
\text { survey date has been changed to } 1999 \text {, which is the } \\
\text { most recent survey for the CAS. }\end{array}$ & \\
\hline $\begin{array}{l}\text { 8.) General } \\
\text { Comments }\end{array}$ & Mandatory & $\begin{array}{l}\text { Due to the magnitude of information presented in } \\
\text { Appendix } \mathrm{H} \text { and for the numerous references to } \\
\text { Appendix } \mathrm{H} \text {, include the applicable section, table, } \\
\text { attachment, etc. Examples would include Sections: } \\
\text { D.9.2 (p. D-58), D.5.2.6 (p. D-34), D.7.2 (p. D-45), } \\
\text { D.9.2.3 (p. D-60). }\end{array}$ & $\begin{array}{l}\text { To clarify the reference to Appendix } \mathrm{H} \text { in Appendix } \mathrm{D} \text {, } \\
\text { the reference have been modified to reference the } \\
\text { specific section of Appendix } \mathrm{H} \text {. }\end{array}$ & \\
\hline
\end{tabular}




\section{Library Distribution List}

\section{$\underline{\text { Copies }}$}

U.S. Department of Energy

1 (Uncontrolled, electronic copy)

National Nuclear Security Administration

Nevada Site Office

Technical Library

P.O. Box 98518, M/S 505

Las Vegas, NV 89193-8518

U.S. Department of Energy

1 (Uncontrolled, electronic copy)

Office of Scientific and Technical Information

P.O. Box 62

Oak Ridge, TN 37831-0062

Southern Nevada Public Reading Facility

2 (Uncontrolled, electronic copies)

c/o Nuclear Testing Archive

P.O. Box 98521, M/S 400

Las Vegas, NV 89193-8521

Manager, Northern Nevada FFACO

1 (Uncontrolled, electronic copy)

Public Reading Facility

c/o Nevada State Library \& Archives

100 N Stewart Street

Carson City, NV 89701-4285 